UNIVERSIDADE DE SÃO PAULO

FACULDADE DE FILOSOFIA, LETRAS E CIÊNCIAS HUMANAS DEPARTAMENTO DE LETRAS CLÁSSICAS E VERNÁCULAS PROGRAMA DE PÓS-GRADUAÇÃO EM LETRAS CLÁSSICAS

ANA CRISTINA DE SOUZA PIRES DIAS

\title{
ALCIBÍADES PRIMEIRO DE PLATÃO: ESTUDO E TRADUÇÃO
}

\author{
Versão Corrigida
}

São Paulo

2015 
UNIVERSIDADE DE SÃO PAULO

FACULDADE DE FILOSOFIA, LETRAS E CIÊNCIAS HUMANAS

DEPARTAMENTO DE LETRAS CLÁSSICAS E VERNÁCULAS

PROGRAMA DE PÓS-GRADUAÇÃO EM LETRAS CLÁSSICAS

\title{
ALCIBÍADES PRIMEIRO DE PLATÃO: ESTUDO E TRADUÇÃO
}

\author{
Ana Cristina de Souza Pires Dias \\ Dissertação apresentada ao Programa de \\ Pós-Graduação em Letras Clássicas do \\ Departamento de Letras Clássicas e Vernáculas da \\ Faculdade de Filosofia, Letras e Ciências Humanas da \\ Universidade de São Paulo \\ para obtenção do título \\ de Mestre em Letras Clássicas
}

Orientador: Prof. Dr. Daniel Rossi Nunes Lopes

\section{Versão Corrigida}

De acordo:

Prof. Dr. Daniel Rossi Nunes Lopes

\section{São Paulo}

2015 
Ana Cristina de Souza Pires Dias

Alcibíades Primeiro de Platão: Estudo e Tradução

Dissertação apresentada ao Programa de Pós-Graduação em Letras Clássicas do Departamento de Letras Clássicas e Vernáculas da Faculdade de Filosofia, Letras e Ciências Humanas da Universidade de São Paulo, para obtenção do título de Mestre em Letras Clássicas.

Aprovada em: 22/06/2015

Banca Examinadora:

Prof. Dr. Daniel Rossi Nunes Lopes (Orientador)

Universidade de São Paulo (USP)

Prof. Dr. Breno Battistin Sebastiani

Universidade de São Paulo (USP)

Prof. Dr. Fernando Maciel Gazoni

Universidade Federal de São Paulo (UNIFESP) 
À minha mãe, Maria Christina de Souza Dias 


\section{AGRADECIMENTOS}

À FAPESP, pelo valioso apoio financeiro e institucional;

Ao Prof. Dr. Daniel Rossi Nunes Lopes, a quem tenho o prazer de ter conhecido e de chamar de professor, pela orientação diligente não apenas durante os anos de minha pesquisa de Mestrado, mas também durante todos os anos de minha graduação, por sempre ter me acompanhado e por ter acreditado no meu trabalho, pela paciência e por todos os conselhos valiosos que me permitiram seguir em frente e concluir esta dissertação;

Ao Prof. Dr. Breno Battistin Sebastiani, não apenas pelo grande auxílio prestado enquanto arguidor na minha qualificação e na minha defesa, mas também por ter me amparado em um momento tão decisivo e importante de minha vida, a quem devo um imenso agradecimento por ter sido fundamental para o meu ingresso no Programa de Pós Graduação em Letras Clássicas da USP;

Ao Prof. Dr. Fernando Maciel Gazoni, por ter composto as bancas de qualificação e de defesa desta dissertação, por todas as intervenções e por todas as palavras que tanto me auxiliaram no desenvolvimento e aprimoramento de minha pesquisa;

Aos meus amorosos pais, que com tanto sacrifício e tanto zelo me educaram neste mundo. Agradeço o imenso amor que me dedicaram e todo o carinho despendido na minha educação. Agradeço, sobretudo, por serem o meu porto seguro e pela relação que construímos ao longo das minhas 28 primaveras;

Ao meu marido, meu terceiro porto seguro. Agradeço pela imensa paciência em lidar com todas as minhas crises, por toda confiança que se renova a cada dia de nossas vidas, por acreditar no meu potencial, por estar ao meu lado, sempre presente, e, sobretudo, por todo amor dedicado;

À Aika, por ser um raiozinho de sol iluminando a minha vida;

A todos os funcionários da instituição, cujo diligente trabalho permite a nossa formação e mantém viva a alma de nossa Universidade. 


\title{
RESUMO
}

O Alcibíades Primeiro está inserido na temática da dimensão educativa da filosofia platônica e consiste num retrato do Eros socrático em perseguição e dedicação ao jovem ateniense que leva o nome do diálogo. A trajetória do diálogo culmina na justificativa da positividade da aporia em que se encontra Alcibíades após o elenchos socrático: a aporia constitui o primeiro movimento do despertar da reflexão crítica a que se submetem aqueles que desejam cursar o caminho da filosofia. Esta dissertação será contemplada por um estudo introdutório baseado no tema geral exposto brevemente acima, além da proposta de uma nova tradução em língua portuguesa a partir da edição do texto grego de J. Burnet (Platonis Opera, Tomus II, 1967).

\section{Palavras-chave:}

1. Platão 2. Filosofia 3. Eros socrático 4. Autoconhecimento 5. Cuidado de si mesmo

\begin{abstract}
The First Alcibiades is inserted into the theme of the educational dimension of Platonic philosophy and is a portrait of the Socratic Eros in his pursuit and dedication to the young Athenian who has the name of dialogue. The path of dialogue culminates in the justification of the positivity of the aporia which Alcibiades has fallen after the Socratic elenchos: the aporia is the first movement of the awakening of critical reflection in which are subdued those who wish to follow the path of philosophy. This dissertation will be contemplated with an introductory study based on the general theme briefly explained above, besides the proposal of a new translation in Portuguese from the edition of the Greek text of J. Burnet (Platonis Opera, Tomus II, 1967).
\end{abstract}

\section{Key-Words:}

1. Plato 2. Philosophy 3. Socratic Eros 4. Self-Knowledge 5. Self-Care 


\section{SUMÁRIO}

PARTE I - ESTUDO INTRODUTÓRIO DO ALCIBÍADES PRIMEIRO p. 7

01- INTRODUÇÃO p. 8

1.1 - Apresentação p. 8

1.2 - Considerações gerais sobre os diálogos platônicos p. 8 02 - ALCIBÍADES PRIMEIRO: DIÁLOGO ESPÚRIO? p. 12

2.1 - A questão da autenticidade do diálogo p. 12

2.2 - Particularidades contra a autenticidade: refutação p. 16

2.3 - A recepção do diálogo na tradição neoplatônica p. 20

03 - O ALCIBÍADES PRIMEIRO DE PLATÃo p. 26

3.1 - Temática do diálogo p. 26

3.2 - A positividade do estado de aporia p. 26

3.3 - A abordagem de Sócrates p. 29

3.4 - O elenchos socrático e o sentido de deslocamento p. 32

3.5 - O justo e o vantajoso: a aprendizagem junto à multidão é possível? .... p. 35

3.6 - A voz e a vez do interlocutor ……................................................ p. 40

3.7 - Experiência de aporia: revelação da dupla ignorância ......................... p. 42

3.8 - Discurso Real - elogio como estratégia de abordagem ....................... p. 44

3.9 - Faces espelhadas: cuidado de si mesmo e autoconhecimento ............... p. 48

3.10 - Relacionamento de papel duplo .................................................... p. 52

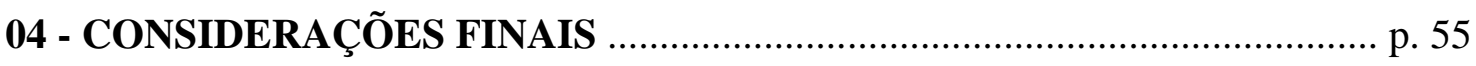

4.1 - Retrato da dimensão educativa da filosofia platônica …………........... p. 55

PARTE II - TRADUÇÃO DO ALCIBÍADES PRIMEIRO DE PLATÃO ......... p. 61

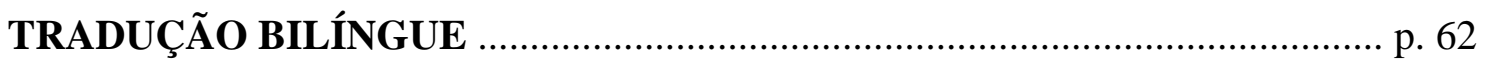

REFERÊNCIAS BIBLIOGRÁFICAS _.................................................... p. 180 


\section{PARTE I}

\section{ESTUDO}

\section{INTRODUTÓRIO}

ALCIBÍADES PRIMEIRO DE PLATÃO 


\section{1 - INTRODUÇÃO}

\section{1 - Apresentação}

O presente trabalho é o resultado da minha pesquisa de Mestrado, realizado a partir do meu ingresso no Programa de Pós-Graduação em Letras Clássicas da Universidade de São Paulo. Esta pesquisa está contemplada por um estudo introdutório e por uma nova tradução em língua portuguesa - a partir da edição do texto grego de J. Burnet - Platonis Opera, Oxford Classical Texts, 1967.

O objetivo do estudo introdutório é o de apresentar, em linhas gerais, os temas mais pertinentes contemplados pelo diálogo Alcibíades Primeiro de Platão. O diálogo relata a primeira abordagem de Sócrates junto a Alcibíades, no momento em que o jovem, prestes a atingir a maioridade, está ávido por ingressar na vida política. A abordagem socrática contém o objetivo de contenção da impulsividade do jovem ateniense em atirar-se precipitadamente na política e o de persuadi-lo a respeito da importância de um preparo adequado para se tornar um verdadeiro líder na cidade. Para isso, contudo, é necessário ao jovem enveredar no caminho do autoconhecimento e cultivar a si mesmo, isto é, trilhar o caminho da filosofia.

\section{2 - Considerações gerais sobre os diálogos platônicos}

Nos diálogos platônicos há uma ligação indissociável entre o conteúdo e a forma literária, sendo ambos igualmente importantes para a compreensão dos problemas filosóficos. Segundo Bolzani ${ }^{1}$, é um erro julgar que a forma dialógica seja moldada a partir de um conteúdo pré-existente com o simples objetivo de abarcá-lo. Sendo assim, os elementos dramáticos dos diálogos não devem ser vistos apenas como ornamento teatral, mas como partes constituintes do que se pode chamar de filosofia platônica.

Além disso, a escolha de Platão pela forma do diálogo não foi produto do acaso ou capricho estilístico: a forma dialógica, além de se aproximar da figura histórica de Sócrates por imitar o exercício oral da prática filosófica, também se torna fundamental para a própria constituição da filosofia tal como concebida por Platão, a qual se 
encontrava intimamente relacionada com a interação entre os interlocutores. O embate entre as personagens e os elementos cênicos são, portanto, partes constituintes da reflexão filosófica nos diálogos platônicos.

A principal personagem presente nos diálogos de Platão, como um todo, é, indubitavelmente, Sócrates. Tão difundida é a sua presença que somente está ausente, como ressalta Kahn ${ }^{2}$, em um único diálogo: “As Leis”. Contudo, esta personagem de Platão não pode ser identificada completamente com a sua persona histórica $^{3}$, visto que Sócrates é representado nos diálogos como uma personagem fictícia construída pelo autor para ser seu principal protagonista.

Essa personagem, apesar de não poder ser confundida com a figura real de Sócrates, possui algum embasamento nela para criar um efeito de verossimilhança, isto é, a persona Sócrates dos diálogos platônicos encontra-se em um continuum entre a figura real de Sócrates e aquele Sócrates concebido por Platão. Nesse sentido, o método não tratadístico e sim dialógico escolhido por Platão para escrever filosofia seria, de uma forma ou de outra, consequiência dessa influência de Sócrates sobre sua trajetória intelectual. Esse aspecto se assemelharia em certa medida à prática dialógica socrática, diferindo dela pela não oralidade: a forma escrita. ${ }^{4}$

Uma outra questão fundamental da prática dialógica utilizada por Platão para compor a sua filosofia é a dos interlocutores. Fora do âmbito da obra, também há um interlocutor, que não se encontra como personagem do diálogo, mas como um interlocutor-ouvinte. É papel deste interlocutor-ouvinte o de ser um observador. A finalidade dos diálogos platônicos é o despertar da reflexão crítica em seus leitores, sendo a aporia comparável a um impulso de fundamental importância para este observador dialogar individualmente com a obra e extrair um sentido filosófico para si próprio.

Na obra em si, por sua vez, a relação ideal para que ocorra o diálogo de natureza filosófica é de reciprocidade e de sinceridade - os interlocutores devem manter uma relação de philia para juntos caminharem na investigação. Nos diálogos, Sócrates, contudo, possui uma relação distinta com os diferentes tipos de interlocutores. Por isso,

$2 \quad$ Kahn, 1996, p. 71.

3 Kahn, 1996, pp. 74-75.

$4 \quad$ Denyer, 2008, p. 9. 
é importante ressaltar que não é em toda ocasião que a relação é regida pela philia, condição essencial para a colaboração mútua em vista de uma conclusão satisfatória da investigação filosófica. Sócrates também pode ser tomado por uma motivação agonística, visando não apenas examinar o problema em questão, mas também prevalecer sobre seu adversário, como acontece, por exemplo, quando discute com os "sofistas", cuja imagem é construída de forma negativa nos diálogos.

A abordagem adotada por Sócrates em cada diálogo, portanto, é formulada a partir da necessidade de se lidar com os diferentes tipos de interlocutores com os quais ele interage. A preocupação do Sócrates platônico, em relação a interlocutores do seu ciclo familiar, como Alcibíades, não é a de transmitir o seu conhecimento através de longas exposições oratórias, mas sim a de auxiliar o interlocutor a alcançar por si mesmo o estágio inicial da reflexão crítica, de modo a se enveredar no caminho da filosofia.

Para Denyer ${ }^{5}$, o método socrático de diálogo - perguntas e respostas - não está fundado em nenhum tipo de autoridade. Pelo contrário, o diálogo filosófico por excelência requer como prerrogativa a igualdade entre os interlocutores, e não está baseado em uma hierarquia de poder. Sócrates pode ser definido como um 'parteiro' de ideias, como referido no Teeteto (148e-151d); ou seja, o filósofo atua apenas como auxiliar no despertar da consciência crítica de seus interlocutores, de modo que não há uma imposição autoritária por parte de Sócrates de certos dogmas.

Se é importante ressaltar, por um lado, a importância da forma dialógica e dos interlocutores dos diálogos, deve-se levar em consideração, por outro, a não linearidade dos diálogos entre si. Apesar de haver intertextualidade entre alguns diálogos, não é possível ordená-los cronologicamente com absoluta segurança. Cada diálogo possui uma completude em si mesmo, mas ao mesmo tempo todos eles fazem parte de um todo, o corpus Platonicum.

Contudo, ainda assim os diálogos platônicos costumam ser divididos pelos estudiosos em três fases, ainda que certos diálogos não se enquadrem claramente em uma ou outra fase: (i) os 'primeiros diálogos', ditos 'socráticos', que são aqueles que se encontrariam sob a maior influência de Sócrates, e que geralmente se caracterizam pela busca de definições de questões éticas culminando em aporia; (ii) os 'intermediários', 
que costumam estender as questões dos primeiros diálogos à luz de doutrinas propriamente platônicas, e que se utilizam de artifícios literários como a exposição de mitos, por exemplo; e (iii) os da 'maturidade', que costumam não conter o encanto literário dos demais; sua forma dialógica pode transparecer apenas uma formalidade; seu conteúdo costuma ser austero e complicado. Além disso, os diálogos dessa fase tendem a possuir uma característica didática e são os que menos se utilizam da figura de Sócrates. ${ }^{6}$

6 Denyer, 2001, p. 20. 


\section{2 - ALCIBÍADES PRIMEIRO: DIÁLOGO ESPÚRIO?}

\section{1 - A questão da autenticidade do diálogo}

Tendo em vista essa divisão dos diálogos platônicos, o Alcibíades Primeiro, segundo Denyer ${ }^{7}$, é um diálogo que não se encaixa satisfatoriamente em uma delas segundo essa ordem supostamente cronológica atribuída ao pensamento de Platão. Isso acontece por o diálogo possuir características pertencentes às três fases do pensamento platônico. Essa característica peculiar do Alcibíades Primeiro é o principal argumento a favor da exclusão do diálogo do corpus Platonicum, sendo que muitos estudiosos já o consideraram espúrio, seja inteiramente, seja parcialmente.

\footnotetext{
“O 'Alcibíades' possui afinidade com cada uma das três fases. Por exemplo, na maneira de um 'primeiro diálogo', 106c-116e representa Sócrates reduzindo seu interlocutor à aporia através de um questionamento incessante sobre ética. Essa passagem contém sete das oito ocorrências de ì ő̋; do diálogo, mas nenhuma

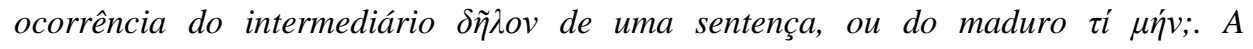
demonstração da execução brilhante de Sócrates em 121a-124b é antes semelhante às suas ocasionais performances estendidas nos diálogos da fase intermediária. Depois dessa execução brilhante, é retomada a dialética, que prossegue muito mais rápida e produtiva do que antes. Logo há a mudança para um estilo que é intermediário ou mesmo maduro. Essa passagem contém ambas as ocorrências do intermediário $\delta \tilde{\eta} \lambda o v$

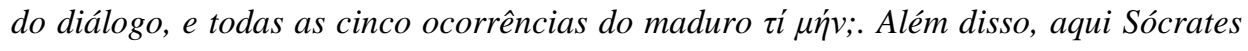
expõe algumas doutrinas metafísicas positivas em um estilo austero e didático (128a$130 c, 132 c-133 c) . " 8$
}

Apesar desse questionamento sobre a sua autenticidade, esta, ainda segundo Denyer $^{9}$, não foi questionada até o começo do século XIX, quando Friedrich Schleiermacher declarara, em 1836, que o diálogo era tão pobre de conteúdo que não poderia ser atribuído a Platão. Também de acordo com Jirsa ${ }^{10}$, Schleiermacher destaca

$\begin{array}{ll}7 & \text { Denyer, 2001, p. } 20 . \\ 8 & \text { Denyer, 2001, p. } 22 . \\ 9 & \text { Denyer, 2001, p. } 15 . \\ 10 & \text { Jakub Jirsa, 2009, p. } 228 .\end{array}$


a ausência de vários aspectos cruciais, tais como a ironia, a filosofia e o amor de Alcibíades por Sócrates. Contudo, ele admitiria que algumas passagens genuinamente platônicas poderiam ser encontradas dispersas na massa do texto do diálogo.

Tal testemunho não teria ocorrido na antiguidade, quando o diálogo era lido frequentemente e considerado, por alguns, digno de ser a primeira leitura para aqueles que pretendiam se iniciar na leitura da filosofia platônica [D.L. 3.62]. ${ }^{11}$

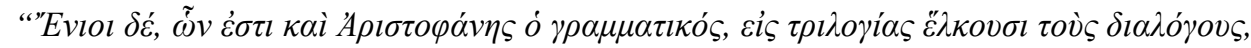

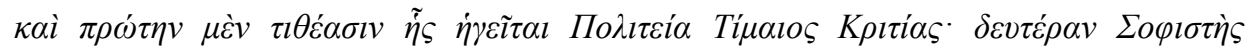

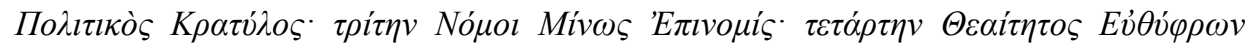

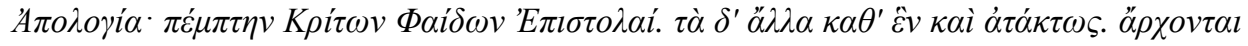

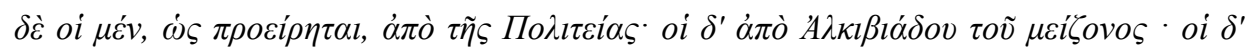

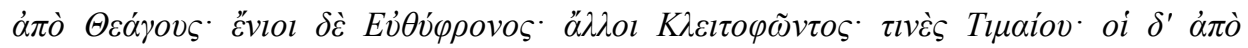

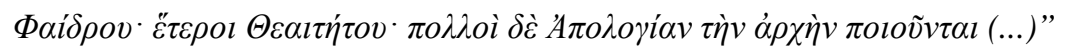

Alguns, dentre os quais o gramático Aristófanes, arranjam os diálogos em trilogias, e colocam na primeira delas a República, o Timeu e o Crítias; na segunda, o Sofista, o Político e o Crátilo; na terceira, As Leis, o Minos e o Epínomis; na quarta, o Teeteto, o Eutífron e a Apologia; na quinta, o Críton, o Fédon e as Epístolas. Os restantes seguiam fora de ordem e considerados individualmente. Mas alguns, como foi dito previamente, começam com a República, já outros, com o Alcibíades Primeiro; outros ainda, com o Teáges. Alguns com o Eutífron; outros com o Clitofonte. Alguns com o Timeu; outros com o Fedro. Outros ainda com o Teeteto; mas muitos fazem da Apologia o começo (...) [Minha tradução] ${ }^{12}$

Também Hutchinson ${ }^{13}$ ressalta brevemente a importância do Alcibíades Primeiro na Antiguidade Tardia, quando era considerado um diálogo ideal para se iniciar o estudo da filosofia platônica, legando-nos extensos comentários de Olimpiodoro e Proclo, além de alguns outros fragmentos de comentários. É afirmado por Proclo: "Então que este seja o início da filosofia e dos ensinamentos de Platão, a saber, o conhecimento de nós mesmos”. 14

11 Denyer, 2001, p. 14.

12 Todas as passagens do texto grego foram traduzidas por mim neste estudo.

13 Plato, 1997, p. 557.

$14 \quad$ Plato, 1997, p. 557. 
Jakub Jirsa, por sua vez, também reafirma o reconhecimento dos antigos em relação à autenticidade do diálogo, o qual é dito ser bem conhecido na tradição platônica e possivelmente também na escola estóica. É preciso ressaltar, entretanto, que Jirsa não entende a visão dos antigos como prova definitiva da autenticidade do texto, visto que também os antigos tinham como genuínas obras que nos dias de hoje são tidas como espúrias, como Teáges, Hiparco ou Minos.

\footnotetext{
"Em distintos períodos do Platonismo, Albino e Jâmblico reivindicaram que ele era o primeiro diálogo a ser lido por qualquer um que adentrasse a filosofia de Platão. Plotino faz referências diversas vezes ao trabalho ('Enéadas' I,1,3,3; IV,4,43,20-1; VI,7,5,24) e nós possuímos extensos comentários de Olimpiodoro e Proclo. E finalmente, Cícero adotou diversos temas em suas 'Tusculanae Disputationes' I,52 e também $V, 70 . " 15$
}

Denyer, por sua vez, antes de iniciar a análise sobre a ordem cronológica dos diálogos platônicos, ainda cita outros argumentos utilizados por certos estudiosos para retirar o Alcibíades Primeiro do corpus Platonicum, os quais ele considera serem frívolos e fracos. São argumentos que concernem à utilização de raras palavras poéticas ${ }^{16}$, ou a medições de estilo que atribuiriam erroneamente ao corpus Platonicum uma homogeneidade técnica. ${ }^{17}$

Hutchinson ${ }^{18}$ ainda cita como argumento para questionar a autenticidade do diálogo o fato de que este predispunha uma interpretação muito simples e direta dentro do escopo dos demais diálogos platônicos, embora considere essa característica peculiar como uma excelente introdução à filosofia.

O argumento da ordem cronológica, que propõe a divisão dos diálogos em três fases do pensamento platônico, como já foi citado, é o único que apresenta maiores dificuldades para aqueles que defendem a autenticidade do Alcibíades Primeiro. ${ }^{19} \mathrm{De}$ acordo com Denyer, se essa cronologia estiver certa, isso tornaria o diálogo inteiramente

$\begin{array}{ll}15 & \text { Jakub Jirsa, 2009, p. } 227 . \\ 16 & \text { Denyer, 2001, p. } 15 . \\ 17 & \text { Denyer, 2001, p. } 18 . \\ 18 & \text { Plato, } 1997, \text { p. } 558 . \\ 19 & \text { Denyer, 2001, p. } 20 .\end{array}$


ou parcialmente espúrio ${ }^{20}$. Contudo, ele defende uma maior flexibilização dessa ordem cronológica e não a considera absoluta no que se refere aos escritos de Platão: o fato de os diálogos platônicos serem melhor compreendidos segundo uma ordem préestabelecida não implica uma rigidez cronológica absoluta referente à ordem de composição escrita dos diálogos ${ }^{21}$.

\begin{abstract}
"Permanece a questão: por que Platão desejaria mesclar no 'Alcibíades' elementos de três estilos literários diferentes? Há uma resposta simples e óbvia. Platão desejava mostrar Sócrates conduzindo Alcibíades de sua condição original e completamente não filosófica a uma condição na qual ele estaria preparado, ao menos para o momento, para praticar razoavelmente algumas sérias questões filosóficas. Essas mudanças intelectuais em Alcibíades, e nos tipos de conversações com os quais ele é capaz de lidar, estão refletidas nas variações de estilo literário, dos 'primeiros', pelos 'intermediários', até os 'tardios',., 22
\end{abstract}

Por sua vez, Jakub Jirsa ${ }^{23}$ argumenta que a dúvida da autenticidade do texto paira mais sobre a incompatibilidade entre o seu estilo ou doutrina e a data de composição assumida do que sobre o seu teor filosófico. A prova da inautenticidade serviria para fortalecer ainda mais a posição da tradicional ordem cronológica, enquanto a sua genuinidade como diálogo platônico abriria espaço para um debate mais amplo sobre a validade da divisão atual dos diálogos em "socráticos" (ou "primeiros"), "intermediários" e "maduros".

A visão de Schleiermacher, segundo Jirsa ${ }^{24}$, prevaleceu até o final dos anos oitenta do século XX, quando ocorreu de Julia Annas publicar um artigo ${ }^{25}$ sobre o autoconhecimento, no qual desafia os argumentos contra a autenticidade do texto. Ao artigo de Annas, seguiu o estudo estilométrico de Gerard Ledger ${ }^{26}$, no qual o Alcibíades Primeiro é classificado como autêntico. Alguns anos depois, começaram a

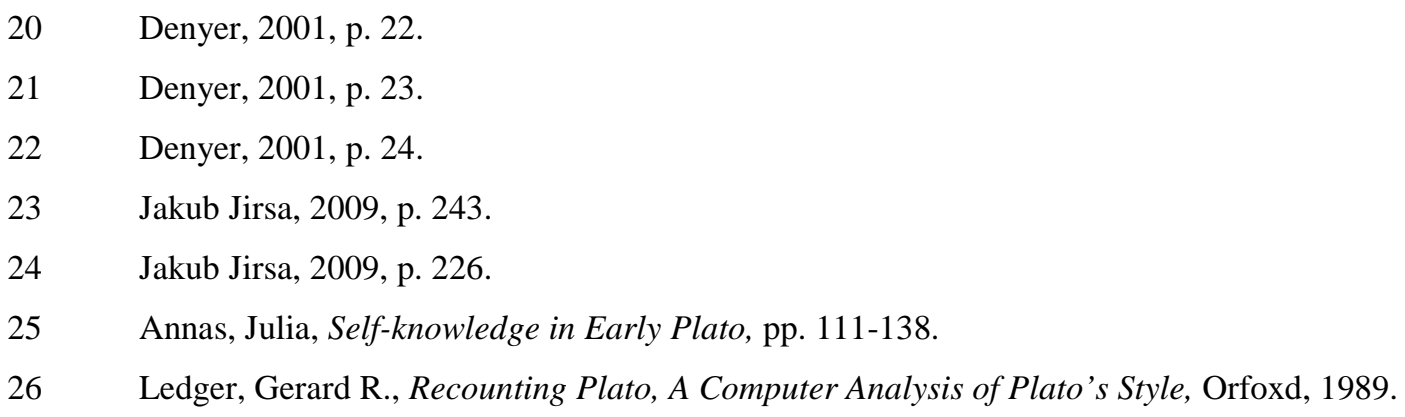


surgir edições do diálogo sem que houvesse a indicação de não ser genuíno, como o acréscimo de "pseudo" ao nome de Platão. A edição do texto de Nicholas Denyer ${ }^{27}$ e a tradução comentada de Jean-François Pradeau e Chantal Marboeuf ${ }^{28}$ servem como exemplo. Jirsa argumenta que essas novas visões não deram um ponto final ao debate em torno da autenticidade do texto, mas fomentaram uma nova discussão.

A posição atual do debate ainda é dividida, de acordo com Jirsa. Contudo são poucos os estudiosos que rejeitam a autenticidade do diálogo sem a necessidade de justificar suas posições ou, ao menos, mencionar que ainda se trata de uma questão controversa. Jirsa ainda afirma que, em contraste com os livros dos anos oitenta ou noventa do século XX, mais autores estão trabalhando com o Alcibíades Primeiro sem dúvidas explícitas em relação a sua autenticidade.

A respeito da questão da autenticidade do diálogo, devo salientar que, apesar de estar particularmente mais inclinada a aceitá-lo como autêntico, por estar mais alinhada com os argumentos dos críticos que defendem a sua autenticidade (mesmo havendo problemas de interpolação em uma passagem ou outra ${ }^{29}$ ), a obra não seria menos merecedora de ser objeto de estudo e tradução, ainda que fosse espúria.

\section{2 - Particularidades contra a autenticidade: refutação}

Jirsa ${ }^{30}$ irá discutir quatro particularidades que são levantadas contra a autenticidade do diálogo, a fim de provar que nenhuma delas é capaz de sustentar, por si só, a tese da inautenticidade do texto: a saber, a particularidade lexical, literária, estilística e os problemas filosóficos.

\section{i. Particularidade lexical}

Os defensores da inautenticidade do texto apontam cinco termos como problemáticos, por supostamente ocorrerem, dentro do corpus Platonicum, com

27 Denyer, 2001.

28 Pradeau, Jean-François - Marboeuf, Chantal, Platon: Alcibiade.

29 Por exemplo, alguns editores consideram a passagem 133c7-18 uma inserção posterior.

30 Jakub Jirsa, 2009, pp. 231-243 


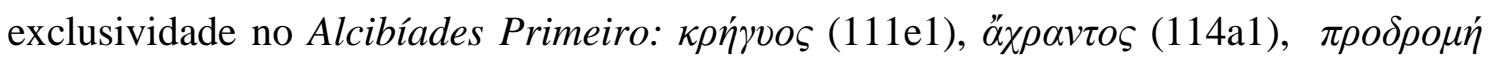

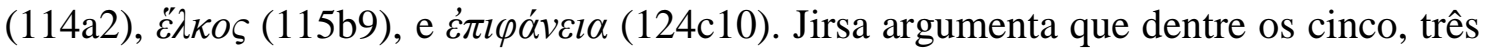

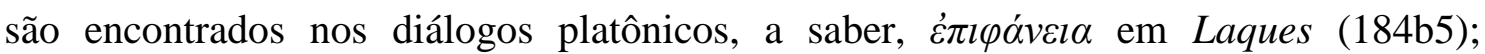

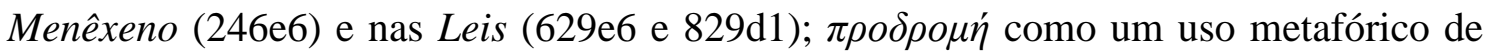
um termo masculino no Cármides (154a4) e, similarmente, o termo ह̌ $\lambda \kappa o \varsigma$ nas Leis

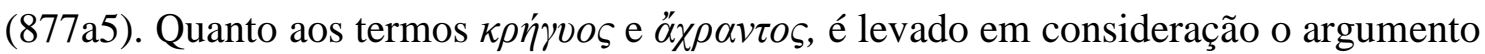
de Denyer ${ }^{31}$ de que, por se tratarem de termos poéticos, o seu uso exigiria explicações de qualquer autor e que Platão utilizaria tais termos com um objetivo bem específico em mente. Além disso, em linhas gerais de defesa, não é a ocorrência única de um termo, por si só, que tornará a obra problemática.

\section{ii. Particularidade estilística}

Jirsa divide os problemas de estilo em dois subgrupos: (a) data da composição e (b) grupo estilístico por pesquisa estilométrica. Segundo o autor, "julgar sobre semelhanças elou diferenças com outros diálogos, na composição e nas doutrinas, não parece ser metodologicamente também um bom processo". ${ }^{32}$ Isso ocorre pelo fato de que, de acordo com essas regras de julgamento, qualquer característica poderia ser ressaltada como prova de inautenticidade do Alcibíades Primeiro, bem como de qualquer outro diálogo. Contudo, o autor julga que o objetivo da similaridade de estilo e de doutrina é o de agrupar os diálogos, dificilmente servindo como prova de inautenticidade. ${ }^{33}$

O tipo de diálogo que representa o Alcibíades Primeiro é um fator de ponderação também para Mark Joyal: sua popularidade entre os antigos concernia ao fato de ele servir como uma excelente introdução aos diálogos e à filosofia platônica, mas será que Platão haveria escrito um diálogo para este exato propósito? Era o questionamento de Joyal. O apontamento de Jirsa em relação a esse questionamento

31 Denyer, 2001, pp. 16, 126, 135.

32 Jakub Jirsa, 2009, p. 232.

33 Jakub Jirsa, 2009, p. 233. 
ocorre de maneira a indicar o propósito educacional dos diálogos platônicos e da própria escola platônica, e o envolvimento de Platão com esse processo educacional:

“Por exemplo, o 'Mênon' serve como uma excelente introdução à epistemologia de Platão, seguido pelo 'Teeteto', mais complicado, e o 'Eutífron' age igualmente bem para os iniciantes em metafísica. Seriam esses dois diálogos espúrios, visto que ocorreriam de ser, de certa maneira, introdutórios, e Platão jamais escreveria uma obra introdutória?" 34

Já a estilometria, por sua vez, levanta duas questões para Jirsa: (i) se é capaz de provar ou desaprovar a autoria, e (ii) se é capaz de auxiliar a estabelecer a data da composição de um diálogo. Com relação ao Alcibíades Primeiro, a pesquisa estilométrica não costumava o levar em consideração, visto que prevalecia a visão de que se tratava de um diálogo espúrio. Quando era considerado, geralmente se encontrava classificado junto aos primeiros diálogos. A última grande pesquisa estilométrica, de Ledger, compartilha dessa opinião com respeito à data de composição e apresenta argumentos estatísticos explícitos para a sua autenticidade. Contudo, Jirsa atenta ao fato de que há um notável recuo da academia contemporânea em relação à estilometria - por ser geralmente problemático partir de grupos estilísticos, mais ou menos estabelecidos, em direção a qualquer estabelecimento de ordem cronológica.

Um argumento utilizado para pôr em dúvida a autoria do texto era o de, uma vez classificado o diálogo dentro de certo grupo estilístico-cronológico, este destoar das características gerais desse grupo; ou seja, alegava-se que o diálogo possuía características filosóficas ou de composição que pertenciam aos demais grupos, e não precisamente àquele apontado primeiramente.

Contudo, Jirsa ${ }^{35}$ afirma que essa peculiaridade não ocorria apenas com o Alcibíades Primeiro: outros diálogos também a compartilhavam, como o Cármides e o problema das relações autorreflexivas, o Eutífron ou o Hípias Maior e a teoria das formas, ou ainda o Teeteto, que apesar da classificação de diálogo da maturidade, possui características que se assemelham aos diálogos socráticos. Jirsa sugere, portanto, que

\footnotetext{
34 Jakub Jirsa, 2009, p. 233.

35 Jakub Jirsa, 2009, p. 235.
} 
Platão utiliza distintas características estilísticas e de composição a fim de lidar com distintos problemas filosóficos ou com distintas abordagens desses problemas, indiferentemente à ordem cronológica.

\section{iii. Problemas filosóficos}

Jirsa ${ }^{36}$ alega que não há nenhuma sugestão de alguma doutrina não platônica no Alcibíades Primeiro; o que há são sugestões de visões divergentes ao compará-lo com outros diálogos. O autor, contudo, vê como problemática a utilização desse argumento para colocar em dúvida a autoria do texto, visto que também há visões divergentes em outros diálogos considerados genuinamente platônicos. O autor questiona como deveríamos distinguir as diferenças doutrinárias que deveriam ser consideradas como um sinal do desenvolvimento filosófico platônico, daquelas que demarcariam uma obra não genuína.

“Esse é exatamente o caso das objeções (d) e (e) de Smith (Nicholas D. Smith, Did Plato write the 'Alcibiades I'?, p. 103). O 'Alcibíades Primeiro' parece ser muito mais a favor da vida política pública e da moralidade comum do que outros diálogos (especialmente a 'Apologia' e o 'Górgias'); mas isso, penso eu, não ocorre porque Sócrates muda de ideia, mas porque ele dialoga com o jovem Alcibíades, que está interessado em uma carreira política, e, além disso, parece ser a sua primeira discussão propriamente filosófica." 37

iv. Particularidade literária

Em linhas gerais, essa particularidade se refere à diferença entre o cenário dramático do Alcibíades Primeiro e o de outros diálogos. Há uma suposição de que Platão deveria ter criado o cenário dramático de modo a não conflitar com outros diálogos e não envolver óbvios absurdos históricos. Schleiermacher considera uma incongruência entre o Alcibíades Primeiro e o Protágoras o fato de que, no Protágoras, Péricles ainda está vivo e, mesmo assim, a interação entre Sócrates e Alcibíades pareça

\footnotetext{
36 Jakub Jirsa, 2009, p. 236.

37 Jakub Jirsa, 2009, p. 236.
} 
ser a de velhos conhecidos, o que não ocorre no Alcibíades Primeiro, diálogo que trata do início da abordagem socrática junto ao jovem. Jirsa ${ }^{38}$ não vê problemas nisso, por considerar que Alcibíades deva estar no início da idade adulta:

“Sabemos que Alcibíades nasceu em 451 ou 450 a.C., no 'Alcibíades Primeiro', ele ainda não tem 20 anos (123d6-7) e Péricles morre em 429 a.C. A data dramática do 'Alcibíades Primeiro' poderia bem ser 432/1 a.C., e, assim, Platão teria pelo menos dois anos em que situar a data dramática do 'Protágoras'., 39

Outro problema apontado que põe em dúvida a autoria do texto é o fato de que o amor do jovem Alcibíades por Sócrates não é manifestado no diálogo, enquanto no Banquete é uma parte essencial do relacionamento entre eles. Contudo, é possível alegar que o Alcibíades Primeiro retrata o primeiro encontro entre eles e que, além disso, sua conclusão carrega a mudança de papéis entre Sócrates e Alcibíades, de modo que o jovem, em seu papel agora de amante (no Banquete), passará a seguir Sócrates, que assumirá o papel de amado.

A única dificuldade que é considerada por Jirsa ${ }^{40}$ é a discrepância entre Sócrates apaixonar-se por Alcibíades alguns anos antes de se aproximar dele no Alcibíades Primeiro (103a-b) e o comportamento invejoso de Alcibíades, que é um empecilho para Sócrates olhar e conversar com qualquer outro belo homem desde o momento em que se apaixonara por Alcibíades (Banquete, 213c6-d1). Contudo, o autor não considera que esse argumento possui força o suficiente para provar a inautenticidade do diálogo, e que ninguém basearia suas dúvidas nisso.

\section{3 - A recepção do diálogo na tradição neoplatônica}

O objetivo de James Ambury ${ }^{41}$ é o de fazer uma observação sobre a parte inicial diálogo, no que diz respeito ao elenchos socrático, sob a luz da tese neoplatônica segundo a qual o autoconhecimento, isto é, o conhecimento do homem como alma

\footnotetext{
$38 \quad$ Jakub Jirsa, 2009, p. 239.

39 Jakub Jirsa, 2009, p. 239.

40 Jakub Jirsa, 2009, p. 240.

41 Ambury, James M., 2011, p. 242.
} 
(130e), é para Platão uma condição necessária para a vida filosófica. Antes de iniciar o seu estudo sobre o elenchos, o qual deverá ser abordado no capítulo seguinte, o autor dá voz às considerações de três comentadores antigos - a saber, (i) o Comentador Anônimo, (ii) Proclo e (iii) Olimpiodoro - os quais não punham em dúvida a autenticidade do Alcibíades Primeiro.

\section{i. Comentador Anônimo}

Nos Prolegômenos à Filosofia Platônica, o Comentador Anônimo enumera diversas razões para a utilização de Platão do "diálogo". Uma das razões mais importantes é o fato de que a forma dialógica reproduz o debate dialético a fim de compelir o leitor a aceitar o argumento da mesma forma que o interlocutor (AC, 1962, 28). O Comentador Anônimo entende como dialética o elenchos, ou seja, a refutação das posições do interlocutor, e o pensamento subsequente pelo qual o interlocutor é levado a dar respostas mais satisfatórias filosoficamente:

\footnotetext{
“O Comentador Anônimo argumenta que a dialética apela para a alma do interlocutor assim como o diálogo é destinado a falar com a alma do leitor. O elenchos não é fácil, mas induz as dores do parto no interlocutor. Através do elenchos, Sócrates se mostra preocupado com Alcibíades, mesmo que ele tente fugir de seus questionamentos em diversas ocasiões e até mesmo culpe Sócrates por sua própria ignorância. $O$ Comentador Anônimo nos mostra que, como leitores, nós passamos pelo mesmo processo e exame do interlocutor. Nós não somos observadores passivos, mas participantes ativos." 42
}

No que diz respeito ao Alcibíades Primeiro propriamente dito, Ambury nos mostra que o Comentador Anônimo compreende o diálogo como o primeiro ao qual devemos nos deter pelo motivo de sermos impulsionados junto ao interlocutor, como leitores, a conhecer a nós mesmos. O Comentador Anônimo entende o processo do conhecimento de si mesmo como o primeiro passo para um conhecimento maior sobre a filosofia: "o curso correto é conhecer a si mesmo antes de compreender as coisas 
externas, pois dificilmente podemos entender essas outras coisas enquanto formos ignorantes de nós mesmos”. 43

Segundo Ambury ${ }^{44}$, os comentadores neoplatônicos estavam fundamentalmente preocupados com o propósito pedagógico dos diálogos e os arranjavam com base nele. $\mathrm{O}$ autor resiste à tentativa dos estudos contemporâneos de agrupá-los em três distintos períodos e de preocupar-se em debater a consistência de Platão nos diálogos, e/ou a mudança de seu pensamento, no chamado "período intermediário", a respeito da existência das Formas e da possibilidade do conhecimento filosófico. À luz da preocupação neoplatônica, que está voltada ao propósito pedagógico dos textos, existe, para o autor, a possibilidade de questionamento e ponderação a respeito da divisão contemporânea dos diálogos.

\section{ii. Proclo}

O conhecimento do homem como alma e, por conseguinte, o autoconhecimento, é considerado por Proclo, assim como pelo Comentador Anônimo, como o melhor ponto de partida para quem deseja trilhar o caminho da filosofia platônica. Contudo, Proclo atenta às pré-condições desse conhecimento: a exortação do interlocutor em direção ao que é bom, a sua indução para avançar em noções não corrompidas e a sua refutação para purificar-se da ignorância dupla. ${ }^{45}$

A ignorância dupla ocorre quando alguém, em um manto de ilusão, julga possuir um conhecimento de algo que está fora de seu alcance: trata-se, portanto, de uma ignorância arrogante, a qual Proclo $(1965,6,115,126)$ acredita ser a responsável por cegar o interlocutor quanto à ignorância simples ou socrática, que é simplesmente a consciência de não saber.

Segundo Ambury, a ignorância socrática é, para os neoplatônicos, um estágio em direção ao autoconhecimento, ou seja, a responsável por abrir um caminho para a reflexão crítica e a busca do verdadeiro conhecimento:

\footnotetext{
43 Ambury, James M., 2011, pp. 242-243.

44 Ambury, James M., 2011, p. 243.

45 Ambury, James M., 2011, p. 244.
} 
"Quando estou ciente da minha ignorância, não estou apenas mais propenso à tentativa de aprender algo que eu não sabia anteriormente, mas também estou em uma posição na qual eu possa investigar as razões para o conhecimento, em primeiro lugar." 46

No caso do Alcibíades Primeiro, o interlocutor homônimo é levado, no primeiro terço do diálogo, a ver a si mesmo em sua própria ignorância - essa primeira parte do diálogo trata da preparação, através do elenchos socrático, para que Alcibíades pudesse, por si mesmo, perceber a sua dissonância cognitiva. Com a dissolução do seu falso saber, ou seja, de sua dupla ignorância, foi aberta para o interlocutor a possibilidade de uma discussão filosófica mais satisfatória, que passaria pelo caminho do autoconhecimento:

"Sem antes tentar conhecer a si mesmo, Alcibíades não tomou as devidas medidas preparatórias requeridas para conhecer a justiça. Ademais, não haveria nenhuma possibilidade de que ele poderia conhecer a justiça [nessas condições]." 47

iii. Olimpiodoro

Olimpiodoro é ainda mais sugestivo do que Proclo, como vemos neste trecho ${ }^{48}$ traduzido por Ambury:

\footnotetext{
“Porque, assim como [SÓC.] diz no 'Fedro': 'apressar-se em saber outras coisas, sem

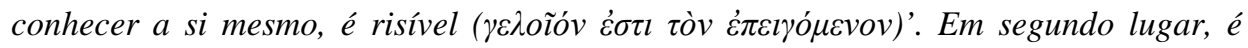

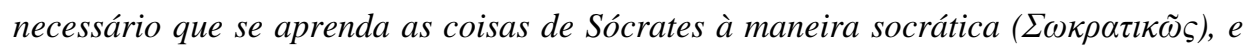
diz-se que Sócrates chegou à filosofia a partir do 'conheça a si mesmo'. Por outro lado,

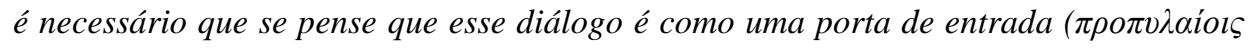

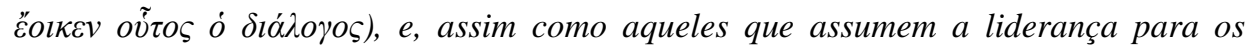
santuários mais íntimos, assim é necessário comparar o 'Alcibíades Primeiro' a uma porta de entrada, mas o 'Parmênides' ao santuário.” [1956, 10.18-11.6]
}

\footnotetext{
46 Ambury, James M., 2011, p. 244.

47 Ambury, James M., 2011, p. 244.

48 Ambury, James M., 2011, pp. 244-245.
} 
Segundo Ambury, são três pontos importantes que podem ser destacados dessa passagem. O primeiro ponto concerne ao acréscimo de um termo que não se encontra propriamente no Fedro, apressar-se, ser impulsivo, ávido. É essa característica do jovem Alcibíades que Sócrates tenta conter no Alcibíades Primeiro: a sua pressa e impetuosidade por ingressar na carreira política assim que atinge a idade adulta, sem nenhum preparo anterior para aconselhar os atenienses sobre a questão da justiça (113c).

O segundo ponto, por sua vez, diz respeito à entrada de Sócrates no caminho da filosofia, o qual se iniciou através da investigação de si mesmo, investigação essa aludida pelo 'conheça a si mesmo' do oráculo de Delfos na Apologia. Olimpiodoro pretende que todos aqueles que desejam se iniciar na filosofia devem percorrer o mesmo caminho de Sócrates, ou seja, uma investigação de seu próprio ser. De acordo com Ambury ${ }^{49}$ :

"Não devemos nos iniciar na filosofia com um tratado que nos diz o que pensar, mas sim por nos envolvermos na dialética. Pensar é essencialmente a alma dialogando consigo mesma (cf. 'Teeteto' 189e). Para preparar-se para o pensamento dialético, é necessário que o interlocutor responda as perguntas de forma honesta para que ele possa vir a reconhecer o papel que desempenha em conhecer alguma coisa.”

O elenchos, portanto, é visto como um meio pelo qual o interlocutor é preparado para conhecer a si mesmo; ou seja, o primeiro passo, que é o reconhecimento da própria ignorância, trata-se de um meio que visa um fim, não é um fim em si mesmo. Olimpiodoro sugere, portanto, que o Alcibíades Primeiro seja o primeiro diálogo a ser lido exatamente por abordar um jovem que irá dissolver a sua dupla ignorância para, enfim, iniciar a jornada em direção ao autoconhecimento.

E por fim, o terceiro ponto trata da sugestão de Olimpiodoro de que o Alcibíades Primeiro é a porta de entrada para o santuário íntimo da filosofia, o qual precede à chegada ao santuário, que é o Parmênides - obra que ilustra bem o pensamento dialético como um diálogo da alma consigo mesma ${ }^{50}$. O Alcibíades Primeiro é

\footnotetext{
49 Ambury, James M., 2011, p. 245.

50 Ambury, James M., 2011, p. 245.
} 
destacado como porta de entrada para a filosofia platônica por ser o conhecimento de si mesmo como alma pré-condição para o pensamento filosófico. 


\section{3 - O ALCIBÍADES PRIMEIRO DE PLATÃO}

\section{1 - Temática do diálogo}

Alcibíades é um jovem ateniense de família proeminente que possui a pretensão de iniciar sua carreira política na vida pública da cidade, almejando ser um de seus políticos mais proeminentes. O jovem, que estava prestes a atingir a maioridade, sentiase preparado para iniciar sue empreitada devido ao seu status entre os atenienses, aos seus recursos, à sua formidável beleza física e ao fato de ter Péricles como seu tutor.

O diálogo trata da abordagem erótico-educativa de Sócrates junto a este jovem, com o objetivo de frear o seu impulso de se lançar prematuramente na vida política e de prepará-lo com um ensinamento adequado para alcançar a excelência, a qual deve possuir quem quer que almeje ser um dia governante. Este aprendizado passa pela compreensão do significado da inscrição de Delfos “conheça a si mesmo", que, segundo Sócrates, seria o cultivo da alma. O autoconhecimento, isto é, o conhecimento do homem como alma, é concebido por Platão como uma pré-condição necessária para a vida filosófica.

O Alcibíades Primeiro de Platão, portanto, está inserido na temática da dimensão educativa da filosofia platônica e consiste num retrato do Eros socrático em perseguição e dedicação ao jovem ateniense que leva o nome do diálogo - isto é, um processo de atração para o caminho da filosofia. A trajetória do diálogo culmina na justificativa da positividade da aporia em que se encontra Alcibíades após o elenchos socrático, quando se vê diante da sua ignorância a respeito de si próprio e se mostra disposto a iniciar uma jornada em busca do autoconhecimento. A aporia, portanto, constitui o primeiro movimento do despertar da reflexão crítica a que se submetem aqueles que desejam cursar o caminho da filosofia.

\section{2 - A positividade do estado de aporia}

Uma questão inicial a respeito do método socrático refere-se à sua aparente negatividade nos diálogos ditos "socráticos". Irwin questiona a sustentabilidade desta 
imagem negativa de Sócrates como filósofo e da própria filosofia socrática ${ }^{51}$. O método argumentativo característico do socratismo é a investigação de seus interlocutores através de um exercício interrogativo com fins refutativos; essa refutação socrática é denominada elenchos. Os interlocutores refutados, por sua vez, partem inicialmente de uma tese moral positiva que será posta em xeque pelo elenchos socrático, de modo que o interlocutor se vê diante de um estado de aporia, isto é, um estado de impasse em relação à veracidade de sua tese inicial.

A sabedoria de Sócrates, entretanto, não consiste em saber as respostas para as perguntas que faz a seus interlocutores - ele próprio afirma não saber essas respostas mas sim na consciência do não saber. Para associar o elenchos socrático a algum tipo de positividade é preciso antes, como ressalta Irwin, compreender de forma distinta a consciência de Sócrates do seu não saber.

A condição não filosófica originária de Alcibíades no Alcibíades Primeiro o levará a um estado primeiro de aporia, no qual os interlocutores de Sócrates normalmente se encontram sujeitos ao final de boa parte dos diálogos ditos "socráticos", tais como, segundo Kahn: Laques, Cármides, Eutífron, Protágoras, Mênon, Lísis. ${ }^{52}$ Esse estado de aporia adquire um sentido positivo na medida em que pode ser visto como o ponto de partida para a reflexão crítica, ou seja, o estado inicial de depuração de opiniões falsas e/ou inconsistentes para o ingresso no procedimento dialético construtivo próprio da filosofia platônica.

Nesse sentido, o episódio do oráculo de Delfos mencionado na Apologia de Sócrates (21a-23c) pode ser considerado como o representante máximo da construção platônica daquilo que diz respeito à suposta filosofia socrática, ou, em outras palavras, como a justificativa da positividade encontrada no exercício de investigação e refutação que Sócrates empregava junto a seus interlocutores e consigo si próprio. A frase inscrita no templo de Delfos - "conheça a si mesmo" - ela própria reflete a experiência de transformação e de autoconhecimento de Sócrates, bem como a origem ou descoberta do sentido de sua filosofia a partir do estado de aporia.

\footnotetext{
$51 \quad$ Irwin, $1995, \mathrm{p} .17$.

52 Kahn, 1996, p. 98.
} 
Nesse episódio, Sócrates não compreende claramente a resposta enigmática da Pítia, sacerdotisa de Apolo, referente à pergunta de seu amigo Querefonte se havia alguém mais sábio do que Sócrates. A resposta oracular, para a surpresa de Sócrates, era a de que não havia ninguém mais sábio (21a). A aporia se deveu ao fato de aquela verdade oracular - verdade que não poderia ser falsa, visto que, na fala do próprio

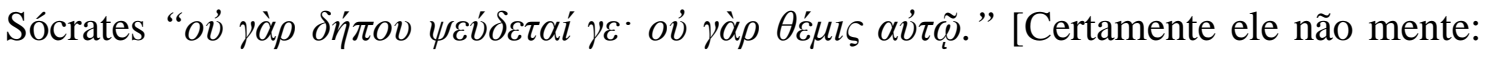
pois não lhe é direito] (21b6-7) - entrar em conflito com a verdade a respeito de si mesmo: o não saber.

É justamente o estado primeiro de aporia no qual Sócrates se encontrava que o

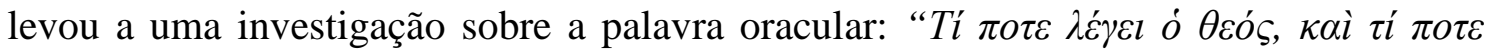

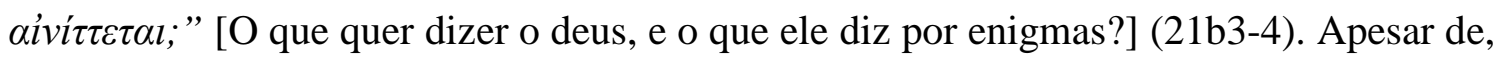
naquele primeiro momento, poder ser considerada uma atitude ímpia de Sócrates para com o deus, a sua verdade interna não poderia ser negada e sua decisão era a de provála para o deus. O estado de aporia gerou em Sócrates um impulso por dissolver o dilema, mantendo uma postura crítica diante da resposta oracular e optando pela investigação com o fim de refutá-la.

A investigação de Sócrates colocou-o de frente com cidadãos reputados sábios na cidade: o político, o poeta e o artesão. A princípio, o seu objetivo era o de refutar o oráculo apresentando-lhe alguém mais sábio do que ele. Porém, a investigação e a refutação por meio do diálogo com esses homens considerados sábios pela cidade acabaram por questionar o valor da doxa, ou seja, até que ponto 'aparentar ser' significa 'realmente ser'.

A verdade aparente, enfim, tornou-se objeto do elenchos socrático. A esfera da opinião pública de um valor atribuído a alguém deixou de ser, a partir da conclusão de sua refutação, critério para estabelecer se este ou aquele indivíduo realmente possuía tal valor; em outras palavras, a doxa não era mais tida como um instrumento para se estabelecer a verdade. Após o resultado de sua refutação, Sócrates enfim pôde compreender a verdade por trás da palavra oracular: a consciência de sua própria ignorância configura-se um saber positivo e possível para o homem. Essa peregrinação de Sócrates em busca de dissolver o estado primeiro de aporia constituiu uma jornada de autoconhecimento e tornou-se a própria configuração do socratismo: 


\section{[23b2-7]}

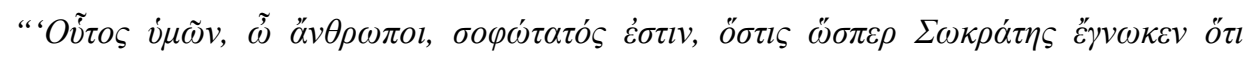

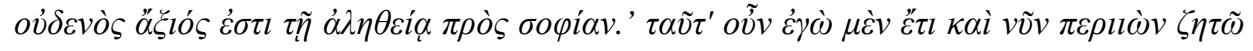

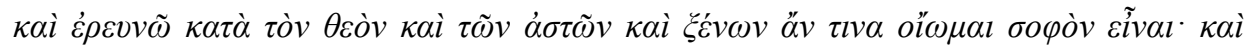

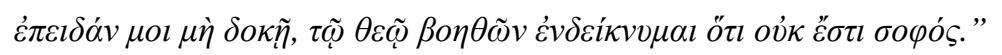

'Entre vocês, ó homens, o mais sábio é quem quer que, como Sócrates, reconheça que, na realidade, em nada é digno em relação à sabedoria' [diz o deus]. A respeito disso, ainda hoje ando por aí investigando e inquirindo, conforme o deus, quem quer que, entre cidadãos ou entre estrangeiros, eu julgue ser sábio. E sempre que a mim não o parece, em auxílio ao deus eu lhe indico que não é sábio.

O elenchos socrático, portanto, consiste em um meio de questionar a sabedoria aparente dos interlocutores a quem Sócrates se dirige, com o objetivo de evidenciar a sua ignorância. A aporia a que geralmente chega parte dos 'diálogos socráticos' também está presente no Alcibíades Primeiro, quando Alcibíades é posto diante de sua própria ignorância dissolvendo a sua aparente imagem de sabedoria. A aporia possui um sentido positivo na medida em que é vista como um instrumento da paideia, ou seja, um instrumento para o processo do despertar da reflexão crítica dos cidadãos atenienses à luz da filosofia, o que implica um processo de investigação de si mesmo e o cultivo da virtude da alma.

\section{3- A abordagem de Sócrates}

De acordo com Scott ${ }^{53}$, Paul Friedländer destaca o Alcibíades Primeiro como uma obra ímpar dentro do corpus Platonicum. Três são os motivos apontados: apesar da aproximação de Sócrates só ocorrer quando o jovem Alcibíades se encontra preparado para o encontro, assim como em outros diálogos, Friedländer aponta o impacto dramático desse artifício no diálogo, o qual é acentuado pelas primeiras palavras de Sócrates - o fato de ter sido impedido de estabelecer contato, até então, por um daimon, pelo motivo de que qualquer tentativa anterior se tornaria vã. Contudo, embora apenas observasse o jovem Alcibíades de longe, é dito que Sócrates acreditava que aguçava a

53 Scott, 2000, p. 82. 
curiosidade do jovem com sua presença silenciosa e sua autoconfiança a respeito das pretensões dele, o que lhe garantia uma audiência atenta ao se aproximar.

O segundo motivo diz respeito à audiência da conversa entre Sócrates e Alcibíades, ou melhor, à falta dela. $\mathrm{O}$ diálogo entre os dois ocorre em privado, sem a presença de espectadores, o que reforça a expectativa de uma conversa mais aberta, clara e honesta - ocasião perfeita para que ocorra o diálogo filosófico sem interferência externa, o qual demanda um estado harmonioso entre os interlocutores $\mathrm{e}$ comprometimento com a honestidade de seus argumentos.

O terceiro motivo, por sua vez, concerne à similaridade que Friedländer enxerga entre os inícios dos diálogos Lísis, Cármides e Alcibíades Primeiro:

\footnotetext{
"Em todos os três contextos, a nobreza e a beleza dos jovens são realçadas, e a conversa surge em resposta a uma característica reveladora do interlocutor. Friedländer recorda que cada diálogo conclui com um lembrete de advertência de que o processo iniciado deve ter continuação além do resultado preliminar que atinge na conversa em questão. Contudo, enquanto os outros dois diálogos implicam uma busca por definições que terminam de forma inconclusiva, Friedländer escreve: 'No 'Alcibiades Primeiro'... o grande movimento do diálogo é de um tipo totalmente diferente. O princípio socrático-platônico do Estado e da paideia prevalece contra as forças hostis de tirania aqui manifestadas em Alcibíades... a própria pessoa histórica ganha vida em sua personagem e destino' "' (Friedländer, Plato, 2:232)
}

Retornando à aproximação entre Sócrates e o jovem Alcibíades no início do diálogo, como já fora mencionado, ela apenas ocorreu pelo consentimento do daimon (103a-b). Isso significa que finalmente chegava o momento oportuno para que suas intenções em relação ao jovem Alcibíades não se tornassem infrutíferas por causa da imaturidade intelectual do jovem. A partir desse momento, sua maturidade poderia começar a ser desenvolvida.

Sócrates era o único amante de Alcibíades que permaneceu em seu encalço, enquanto os demais já haviam desistido da empreitada porque o próprio Alcibíades os afugentara (103b-104b) devido ao seu comportamento soberbo e ao seu altivo juízo sobre si mesmo - sua beleza física, sua origem proeminente e a tutoria de Péricles faziam com que Alcibíades se julgasse superior a todos os demais, apto para ingressar em uma proeminente carreira política. 
Além de ser o único amante que permanecera na perseguição a Alcibíades, Sócrates alega que é o único capaz de auxiliá-lo em sua empreitada rumo a uma vida pública de sucesso:

\begin{abstract}
[105d2-e5]

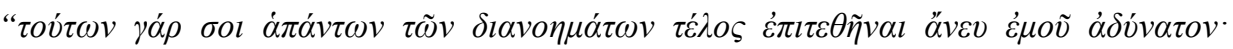

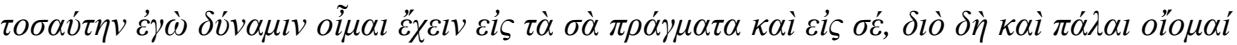

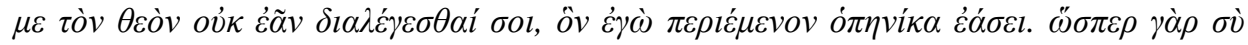

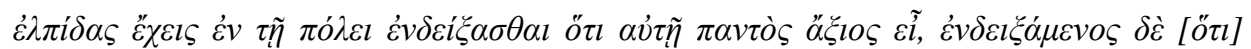

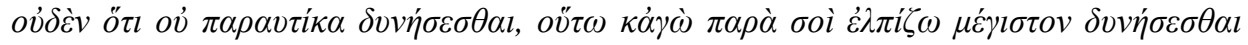

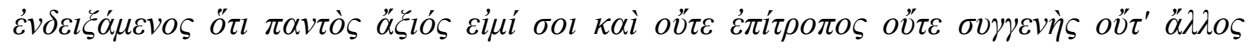

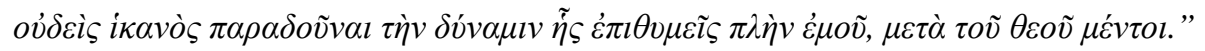

(...) é que a realização de todos esses seus planos é impossível sem mim. Eu julgo possuir tamanha influência sobre suas coisas e sobre você, que, em razão disso, penso que por muito tempo o deus não me permitia dialogar com você, e eu fiquei esperando o momento de sua permissão. Assim como você espera provar para a cidade que merece todas as honrarias da parte dela, ao ter mostrado que não há nada de que agora não seja capaz, também eu espero que eu seja capaz de ser o homem mais influente sobre você, ao ter mostrado que mereço todas as honrarias de sua parte, e que nem tutor, nem parente, nem qualquer outro homem tem a competência para lhe oferecer a capacidade que almeja, exceto eu - com a ajuda do deus, decerto.
\end{abstract}

Gordon ${ }^{54}$ admite que o motivo de Sócrates ser o único capaz de auxiliar o jovem Alcibíades em suas pretensões políticas é bem desenvolvido no diálogo e está fundado no eros. Outra reivindicação de exclusividade por parte de Sócrates se dá nas passagens em que afirma ser o único amante verdadeiro de Alcibíades (131e/132a). Essas passagens estão fundadas, sobretudo, na dicotomia corpo/alma, sendo o verdadeiro amor aquele que transcende o corpo e se liga à alma do amado: diferentemente dos demais amantes, que se encantavam com a beleza juvenil de Alcibíades, o amor de Sócrates não desvanece quando a beleza se esvai - trata-se do amor pela alma do jovem. Por isso, Gordon conclui que apenas Sócrates é capaz de satisfazer o eros de Alcibíades, por ser o único que verdadeiramente o conhece.

$54 \quad$ Gordon, 2003, p. 12. 
Um último ponto acerca da superioridade de Sócrates em relação aos demais, entendidos aqui não somente como os amantes de Alcibíades, mas também como os seus tutores, diz respeito a sua maior fonte de inspiração: Péricles. Já no início do diálogo, Péricles é exortado como um dos maiores recursos do jovem ateniense (104b). Contudo, é na passagem de 118b-e que Sócrates reduz o valor desse recurso aos olhos de Alcibíades: apesar de Péricles ser considerado por ambos um homem sábio, frequentador de outros homens sábios, é dito ser incapaz de transmitir a sua sabedoria a outras pessoas, a começar por seus filhos e seus tutoriados:

\begin{abstract}
"Sócrates parece incitar os desejos de Alcibíades por poder e maestria, e, de uma maneira relativamente pouco sutil, dar a entender que Péricles não é capaz de the fornecer o que ele deseja. Os meios pelos quais Sócrates reforça aqui o seu objetivo de seduzir Alcibíades são o de invalidar um dos 'guias' atuais de Alcibíades, e, implicitamente, o de sugerir que ele, Sócrates, seria um 'guia' superior." 55
\end{abstract}

\title{
3.4 - O elenchos socrático e o sentido de deslocamento
}

Segundo Ambury ${ }^{56}$, o objetivo do elenchos pode ser mais bem compreendido através do que ele denomina 'deslocamento', isto é, um estado de aporia radical que leva o interlocutor a encarar a si mesmo, exposto por inteiro, de modo que lhe sejam reveladas as conseqüências problemáticas ou as inconsistências de suas opiniões (em outras palavras, a sua ignorância). O autor ainda considera o deslocamento como um movimento vital para que o interlocutor possa admitir a sua ignorância e, por conseguinte, abrir-se para a filosofia.

O objetivo do elenchos, portanto, pode ser apontado como o deslocamento de Alcibíades em relação à sua altiva consideração sobre si mesmo, tanto no que confere aos seus atributos físicos e aos recursos que lhe eram disponíveis, quanto à sua maturidade intelectual e preparação para a vida política.

"O deslocamento requer uma mudança fundamental segundo a qual o que era percebido como normal por Alcibíades é experimentado como bizarro ou estranho. Sem

55 Gordon, 2003, p. 16.

56 Ambury, James M., 2011, p. 242. 
o deslocamento, não há necessidade de se fazer perguntas sobre o que alguém sabe ou não sabe, e, sem fazer um balanço de sua ignorância, Alcibíades irá continuar a evitar investigar o que é um ser humano. Sócrates, ele próprio, parece estranho no começo do deslocamento e por isso desperta em Alcibíades o espanto pelo qual se inicia a filosofia." 57

No início do diálogo, a perseverança de Sócrates em não abandonar o cortejo de Alcibíades é causa de espanto e curiosidade para o jovem, que, ao mesmo tempo em que se sentia irritado pela presença constante e silenciosa de seu amante, sentia a sua curiosidade ser fomentada. Vejamos a seguinte passagem do diálogo:

\section{[104d2-3]}

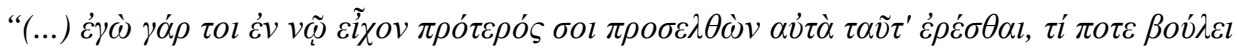

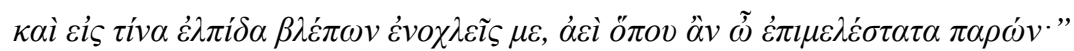

(...) Pois eu tinha, de fato, a intenção de me aproximar de você para perguntar estas

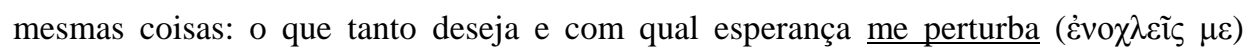
estando sempre presente da maneira mais cuidadosa onde quer que eu esteja.

O verbo $\varepsilon \dot{v}$ vo $\chi \varepsilon \tilde{\varepsilon}{ }^{58}$ expressa não somente a irritabilidade de Alcibíades, mas também a sua perturbação quase eufórica em relação à presença tão persistente de Sócrates, o único amante que não fora afugentado ou desistira dele. Ou seja, a atitude perturbadora de Sócrates também teria a capacidade de despertar a curiosidade em Alcibíades e essa característica facilitaria a aproximação do filósofo, por já ter criado um tipo de tensão em seu futuro interlocutor.

A exposição dos motivos de Sócrates elenca não somente o seu profundo conhecimento a respeito da ambição política de Alcibíades e o seu anseio por poder (104e-105c), mas também um apelo de exclusividade: como já o fora mencionado anteriormente, Sócrates coloca-se na posição de ser o único capaz de conduzir Alcibíades ao sucesso, presumindo que sua influência seja a maior e a mais necessária $(105 d-e)$.

\footnotetext{
57 Ambury, James M., 2011, p. 246.

58 Ambury, James M., 2011, p. 246.
} 
Ambury argumenta que a exposição dos motivos de Sócrates causa um enorme estranhamento em Alcibíades, que pensa que o amante estaria ainda mais deslocado

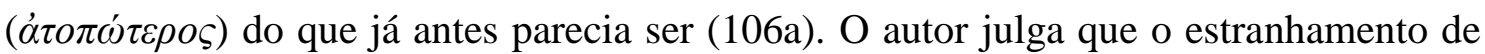
Alcibíades ocorre pelo motivo de Sócrates não se inserir na noção comum de um amante, como eram os demais: o jovem estava acostumado com um cortejo diferente, comum a todos os outros amantes, isto é, o cortejo de sua beleza juvenil e de sua elevada posição social. Contudo, o cortejo de Sócrates não se fazia em vista do belo corpo de Alcibíades, mas em vista de sua alma. Ambury ainda afirma que: "Sócrates, visto da perspectiva daqueles que não conhecem a si mesmos, é completamente bizarro. O deslocamento de Alcibíades, portanto, começa com Sócrates parecendo estar fora do lugar." 59

A maneira com que Sócrates fará para Alcibíades vê-lo com outros olhos é a de levar o jovem Alcibíades a sentir-se deslocado de si mesmo, isto é, receoso de suas próprias convicções, como alguém que vê uma imagem ofuscada de si mesmo diante de um espelho, para que depois possa, ao trilhar o caminho do autoconhecimento, enxergar a sua imagem com clareza. O deslocamento pode ser visto, portanto, como o primeiro passo em direção à filosofia; um passo decerto perturbador, porém necessário para o conhecimento.

À maneira socrática, segundo Ambury ${ }^{60}$, o primeiro passo em direção ao deslocamento de Alcibíades se dará através de um comprometimento verdadeiro com o diálogo. Nesse sentido, é necessário que aconteça o elenchos, pois uma audição de um discurso retórico longo, como Alcibíades estava acostumado a ouvir, não seria suficiente para o despertar de sua reflexão crítica. O objetivo da refutação socrática é o de tornar a participação do interlocutor indispensavelmente ativa, a qual é impossibilitada diante de uma apresentação retórica.

Como antes referido, os neoplatônicos relacionam a forma dialógica escolhida por Platão com o seu objetivo pedagógico. Há a preocupação de que os leitores possam percorrer, ativamente, o mesmo processo educativo dos interlocutores dos diálogos. Ambury ${ }^{61}$ menciona, inclusive, que a disposição dos diálogos feita pelos neoplatônicos

$\begin{array}{ll}59 & \text { Ambury, James M., 2011, p. } 247 . \\ 60 & \text { Ambury, James M., 2011, p. } 247 . \\ 61 & \text { Ambury, James M., 2011, p. } 243 .\end{array}$


visava ao ensinamento de seus educandos sobre os princípios básicos da filosofia platônica, os quais seriam mais bem apreendidos através da interação (com os interlocutores) oferecida pela forma dialógica.

Já Scott, em uma analogia com a Apologia (30e), ressalta o papel do elenchos socrático como um moscardo (que perturba e incita), o qual é dito possuir três funções essenciais: (i) exortar os demais a se preocuparem antes com a virtude do que os bens relativos ao corpo, como o dinheiro e o prazer; (ii) examinar aqueles que dizem possuir essa preocupação como prioridade; e (iii) expor qualquer falta que a investigação revelar no que se refere a esse cuidado com a virtude ${ }^{62}$. No que se refere ao Alcibíades Primeiro, Scott ${ }^{63}$ considera que:

"Sócrates não apenas desmascara as grandiosas aspirações de Alcibíades, como também o confronta com a notícia desanimadora de que o futuro estadista tem sido treinado insatisfatoriamente, o que o torna, portanto, inadequadamente preparado para defrontar-se com os seus derradeiros rivais na arena política."

\section{5 - O justo e o vantajoso: a aprendizagem junto à multidão é possível?}

O início do questionamento de Sócrates a Alcibíades trata do almejo do jovem de ser o melhor conselheiro entre os seus concidadãos atenienses. De acordo com Sócrates, Alcibíades só poderia aconselhar a respeito daquilo de que possuísse um conhecimento maior do que os demais homens (106c-d), o que o jovem supõe possuir. Sócrates conclui, então, que o jovem adquiriu esse conhecimento através do ensinamento de outrem ou através do próprio descobrimento (106d).

Alcibíades, ainda de acordo com Sócrates, no decorrer de sua infância e adolescência teria aprendido as letras, a tocar cítara e a lutar - a tocar aulo não, visto que não o quis. O jovem confirma a veracidade da informação de Sócrates e confessa que, de fato, não frequentara outras matérias (106e). Decorre do argumento, contudo, (107a) que essas matérias não são objetos de deliberação dos atenienses, mas sim as matérias que são próprias às cidades, como a guerra ou a paz (107d), e que o melhor nas deliberações sobre essas questões acontece de ser o indivíduo que é mais justo (109c).

62 Cf. Apologia 29d-30b.

63 Scott, 2000, p. 86. 
Em relação às artes especializadas (107a-ss), Sócrates argumenta que um especialista - ou seja, alguém que aprendeu a arte e a conhece profundamente - é fundamental para ensiná-la e também para ser consultado a respeito dela. Por exemplo ${ }^{64}$, no que diz respeito à saúde pública, os médicos são procurados por possuírem o conhecimento necessário das questões relativas ao corpo, assim como os demais especialistas são consultados a respeito de seus ramos: por que, então, seria diferente com a arte política? Disso segue o questionamento de Sócrates: com qual professor Alcibíades aprendeu as questões relativas à justiça, a discernir o justo do injusto?

\section{[109d1-5]}

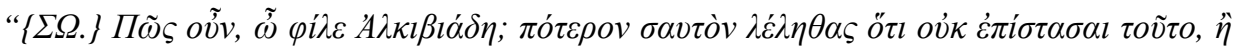

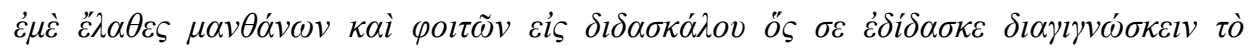

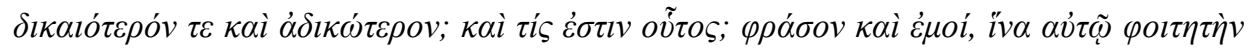
$\pi \rho o \xi \varepsilon v \eta \dot{\sigma} \eta \varsigma \kappa \alpha i ̀ ~ \varepsilon \dot{\mu \varepsilon ́ . " ~}$

[SÓC.] E agora, meu caro Alcibíades? É você que não percebe que não possui conhecimento a respeito disso, ou fui eu que não me dei conta do seu aprendizado com um professor que lhe ensinou a discernir bem o mais justo do mais injusto? E quem é ele? Diga-me quem é para que você me recomende a ele como pupilo.

Alcibíades (109e), em um primeiro momento, discorda da necessidade de ter aprendido as questões relativas à justiça junto a alguém e questiona se não haveria outra maneira de tê-las aprendido, ao que Sócrates novamente responde que lhe seria possível ter descoberto por si mesmo através de uma investigação, caso tivesse julgado não conhecê-las. Alcibíades assim o concede: que houve um tempo em sua vida que pensava não conhecê-las.

Em vista disso, Sócrates mostra a Alcibíades que ele estava errado em sua suposição, pois o jovem nunca pensara que não conhecia a justiça, ao contrário, ele sempre julgou conhecê-la, desde pequeno (110a-c). Em relação a essa parte, Ambury ${ }^{65}$ salienta três pontos importantes:

\footnotetext{
64 Ambury, James M., 2011, p. 252.

65 Ambury, James M., 2011, pp. 253-254.
} 
i. A conclusão de Sócrates de que Alcibíades já assumia na infância possuir conhecimento sobre a justiça se baseia no fato de que o jovem nunca se sentiu em aporia, ao pensar sobre a justiça (110b);

ii. Sócrates dá prioridade à questão no final da sentença, 110b9-10: “ $\{\Sigma \Omega$. $\}$

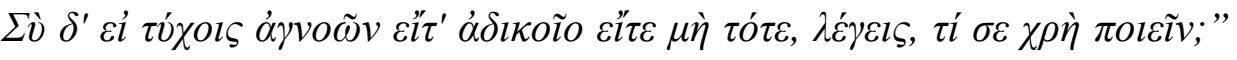
[\{Sóc. $\}$ Se por acaso ignorasse naquela ocasião se era ou não injustiçado, diga-me você: o que devia fazer?]. Ambury argumenta que estamos mais inclinados a fazer perguntas quando conscientes de nossa própria ignorância do que quando operamos nas premissas que conhecemos. Sendo assim, ele sugere que Alcibíades nunca teria se questionado a respeito desses assuntos e que Sócrates não teria sugerido que Alcibíades não poderia perceber que estava sendo injustiçado, mas sim que o jovem não conheceria a justiça filosoficamente;

iii. Alcibíades, por sua vez, faz uma defesa veemente de que havia clareza no seu reconhecimento do ato de injustiça que sofrera, contudo é incapaz de precisar a época que ignorava o que era a justiça. Dá-se a conclusão de que o jovem, portanto, não a havia descoberto por si mesmo. Ambury observa que Sócrates desafia a afirmação de que Alcibíades poderia conhecer a justiça sem antes ter sido deslocado das maneiras ordinárias de conhecer:

\begin{abstract}
“Do ponto de vista socrático, não há tal coisa como clareza imediata. Há apenas entendimento que resulta do processo de discussão dialética, e não há razão para se envolver na dialética sem autoconhecimento. Alguém apenas ouviria a apresentação retórica e então regurgitaria informações sobre a justiça em vez de uma compreensão filosófica. Sem dialética não há nenhuma possibilidade de que Alcibíades teria descoberto a verdadeira natureza da justiça”. 66
\end{abstract}

Se Alcibíades (110d-e) não aprendeu sobre justiça junto a um professor e nem descobriu por si mesmo, de que maneira ele poderia conhecê-la? É o próximo questionamento de Sócrates, ao que Alcibíades responde que aprendera da mesma 
forma que os demais, isto é, junto à multidão. De acordo com Mintoff ${ }^{67}$, o Alcibíades Primeiro teria, junto ao Grande Discurso (316b-324d) de Protágoras no diálogo homônimo, o tratamento mais extensivo do que diz respeito à competência da maioria em ensinar a virtude.

Como primeiro argumento para refutar Alcibíades, Sócrates argumenta que a multidão não é muito estimável como educadora, por não ser competente em ensinar nem mesmo matérias triviais, como os movimentos do jogo de gamão, que são insignificantes em comparação a questões de justiça (110e). Alcibíades, no entanto, discorda que a multidão não possa ser boa professora de questões mais importantes do que gamão, pois ele mesmo afirma que pessoas comuns o ensinaram a falar grego (111a).

Mintoff ${ }^{68}$ destaca as premissas de Sócrates em relação às questões mais triviais e em relação à justiça, considerando que a maioria pode ser boa professora de grego ao possuir conhecimento suficiente sobre a matéria, o que não ocorre no que concerne às questões de justiça:

i. A respeito das questões mais triviais, pessoas comuns concordam sobre o que é uma pedra ou uma madeira, e dão a mesma resposta quando questionadas a respeito disso (111b-c); e é igualmente assim a respeito das questões gramaticais. Ou seja, em geral, as pessoas costumam concordar consigo mesmas e umas com as outras nessas questões e, por causa disso, elas seriam boas professoras dessas matérias (111c).

ii. Já a respeito da justiça, a relação das pessoas com elas mesmas e umas com as outras não é de concordância, mas sim de divergência (111e112a). Sócrates ainda argumenta que a divergência é tanta entre as pessoas que muitas até mesmo acabam por perder as suas vidas em conflitos gerados por essa discordância, como entre os Aqueus e os Troianos, os Atenienses e os Lacedemônios (112a-c). Tendo em vista tamanha divergência, a conclusão seria que as pessoas não possuiriam

\footnotetext{
67 Mintoff, Joe, 2012, p. 90.

68 Mintoff, Joe, 2012, p. 92.
} 
compreensão dessas matérias $(111 b, 112 \mathrm{~d})$ e, portanto, não seriam boas professoras delas (111a-b).

Alcibíades, ainda não preparado para admitir e nem convencido de sua ignorância a respeito das questões relativas à justiça, altera o argumento para a questão do "vantajoso", por não considerar que as deliberações dos helenos almejem as ações mais justas, e sim as mais vantajosas. Igualmente em relação ao justo e ao injusto, o jovem não conseguiria responder se aprendera as questões relativas ao vantajoso junto a alguém, ou se descobrira por si mesmo. Por isso, Sócrates lhe solicita que demonstre se o justo e o vantajoso são a mesma coisa ou se são coisas distintas (114a). O jovem ateniense, por sua vez, busca inicialmente estabelecer que a justiça e a vantagem não são a mesma coisa, e que pode a justiça ser vantajosa em alguns casos e desvantajosa em outros (113d). Em resposta, o elenchos socrático lhe expõe o erro do argumento e estabelece que as coisas justas são vantajosas (113e-116d).

\footnotetext{
"Que Alcibíades e a multidão façam distinção entre o que é justo e o que é vantajoso demonstra que eles não conhecem a si mesmos. Se alguém conhece a si mesmo como alma, não pode haver diferença entre o que é justo em geral e o que é vantajoso para os atenienses em particular: como alma, fazer o que é justo ou é a mesma coisa que fazer o que é vantajoso ou não é; não pode ser ambos. Alcibíades e a Assembleia ateniense não vêem isso porque eles estão preocupados em fazer o que lhes parece melhor. A única forma que alguém, possivelmente, pensaria assim é se não reconhecesse que a justiça carrega a mesma identidade para todos os seres humanos. Consequentemente, a justiça não pode ser vantajosa para um grupo de pessoas e prejudicial para outro. A justiça deve ser a mesma, independentemente do tempo e lugar. Ou é a mesma coisa que o vantajoso ou não é." 69
}

Ainda segundo Ambury ${ }^{70}$, a maioria, apesar de ser boa professora de grego, não seria qualificada para ensinar sobre questões de justiça, pois a justiça é uma constituição humana mais complexa, objeto de divergências. Sem primeiro saber sobre os seres humanos, tanto a multidão quanto Alcibíades não poderiam saber que a justiça é sempre

69 Ambury, James M., 2011, pp. 255-256.

70 Ambury, James M., 2011, p. 255. 
vantajosa. A distinção entre justiça e vantagem só seria estabelecida entre aqueles que não foram deslocados das noções atenienses típicas de justiça e não conhecem a si mesmos, não sendo capazes, portanto, de conhecer nada no sentido filosófico.

\section{6 - A voz e a vez do interlocutor}

Há uma importante digressão no diálogo (112e-113c) a respeito da função e da importância da voz do interlocutor. Essa pequena digressão pode ser entendida como uma breve explicação da importância das vozes ativas no diálogo, por ser o método dialógico capaz de permitir que os interlocutores sejam donos de suas próprias vozes e que tenham uma participação ativa na construção do conhecimento.

Alcibíades, além de não admitir a sua falha cognitiva no que se refere às

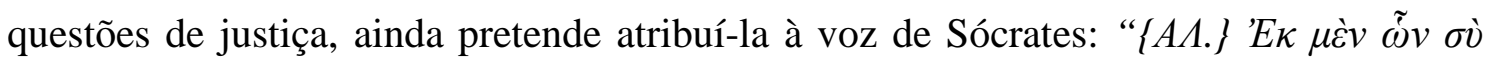

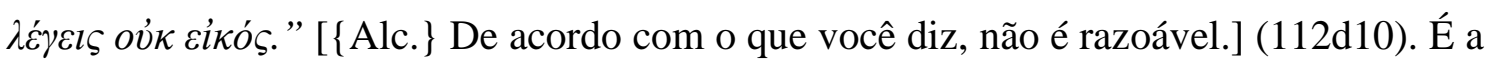
partir daí que se inicia uma discussão a respeito da participação do interlocutor como voz ativa no diálogo. De acordo com Ambury ${ }^{71}$, ao esquivar-se da responsabilidade sobre suas opiniões, Alcibíades foge do deslocamento e atribui sua falta de conhecimento aos questionamentos de Sócrates, e não à sua falha em responder as perguntas.

Retornando ao início do diálogo (106a), Alcibíades havia solicitado a Sócrates uma explicação sobre a necessidade de sua influência direta para que ele pudesse alcançar os seus objetivos. Por sua vez, Sócrates afirmou que a resposta não seria concedida por meio de discursos longos, com os quais o jovem estava acostumado, e sim através da colaboração de Alcibíades em se engajar em um diálogo. No entanto, o jovem ainda se encontrava em um estágio imaturo para a participação em um diálogo filosófico, tão imaturo que ainda não era capaz de compreender o básico que lhe era necessário, isto é, o comprometimento com os seus próprios argumentos.

O jovem Alcibíades ainda estava acostumado a ocupar o lugar de ouvinte passivo diante dos discursos dos oradores, o que pode sugerir que ele ainda não havia ocupado o protagonismo na construção do seu conhecimento. O protagonismo seria, por

71 Ambury, James M., 2011, p. 248. 
conseguinte, exercido unicamente pelo orador, restando para os seus ouvintes o papel de enaltecer a sua capacidade oratória.

Apenas para efeito de um breve apontamento, a cena do sofista Protágoras, no diálogo homônimo, serve como uma excelente ilustração da percepção platônica da postura de oradores proeminentes. Na casa de Cálias, encontravam-se junto ao sofista muitos homens que desejavam ouvi-lo, atraídos pela sua reputação de sábio, dentre os

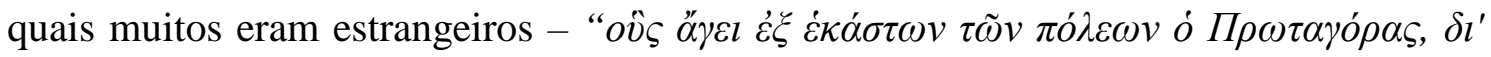
$\tilde{\omega} v \delta l \varepsilon \xi \xi \varepsilon \chi \varepsilon \varepsilon \tau \alpha \iota$ (...)” [que Protágoras atraía de cada uma das cidades pelas quais passava (...)] (315a7-8). Platão elabora uma analogia entre os ouvintes do cortejo de Protágoras e o coro do teatro:

\section{[315b2-8]}

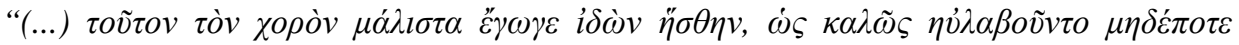

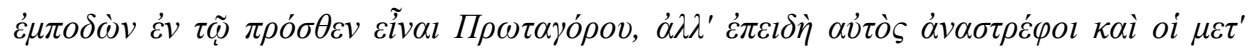

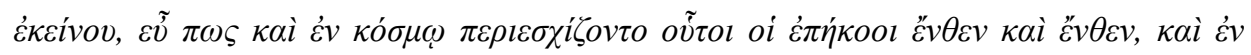

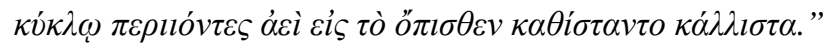

(...) Eu mesmo muito me deleitei ao ver esse coro, como com beleza se precavia para que não fosse obstáculo diante da passagem de Protágoras, mas assim que ele e os que estavam em sua companhia se viravam, de maneira elegante e em boa ordem os ouvintes dividiam-se para um lado e para o outro, e, ao darem a volta em círculo, em uma bela ação, sempre retomavam o seu lugar atrás [de Protágoras].

A posição da maioria de seus discípulos, com exceção dos mais proeminentes, não era ao seu lado, e sim atrás dele, esforçando-se por não atrapalhar o seu caminho. Essa cena merece destaque, pois ela indica que o conteúdo proferido por Protágoras perdia importância frente à visível preocupação de abrir caminho para a sua passagem. Nessa cena também fica evidente o papel de protagonismo ocupado unicamente pelo sofista, enquanto os demais apenas ocupariam a função de enaltecer a voz do orador e a sua autoridade, visto que suas vozes não possuíam função.

O diálogo filosófico proposto por Sócrates (106b), portanto, deve ser entendido não somente como um meio de participação dos interlocutores, mas também como método que os instiga a criarem os seus lugares como sujeitos ativos na investigação do saber e donos de suas próprias vozes, comprometidas essas com os próprios argumentos em questão. É daí que se segue a importância do apontamento de Sócrates de que o 
responsável pelas respostas, e também pelas suas próprias falhas, seria unicamente o próprio Alcibíades (113a-c). Ambury ${ }^{72}$ destaca a noção de Alcibíades ser, ao mesmo tempo, o acusador e o acusado, responsável pela percepção de sua própria ignorância.

\section{[113c2-4]}

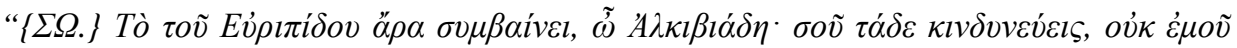

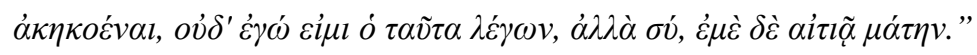

[SÓC.] Portanto, ocorre o que diz Eurípides, ó Alcibíades: "tais coisas você deve ter ouvido de você, e não de mim, tampouco sou eu quem está dizendo, mas você mesmo, e a mim acusa em vão."

\section{7 - Experiência de aporia: revelação da dupla ignorância}

A continuidade do elenchos socrático, após a breve digressão do diálogo (112e113c) comentada acima, pretende estabelecer a identidade entre o justo e o vantajoso. Nesse momento (114b), Sócrates oferece a Alcibíades a oportunidade de tomar o seu lugar de inquiridor, ou de expor, ele próprio, seus argumentos. O jovem, no entanto, mostra-se hesitante em expô-los diante de Sócrates, motivo pelo qual é defrontado pelo filósofo. Sócrates argumenta que, se Alcibíades é capaz de persuadir a muitos na assembleia, também será ele capaz de persuadir um indivíduo isoladamente:

\section{[114b6-7]}

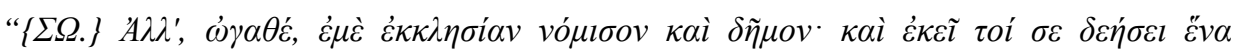

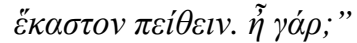

[SÓC.] Então, bom homem, considere-me como se eu fosse a assembleia e o povo, pois lá você deverá persuadir a cada indivíduo. Ou não?

Incapaz, no entanto, de expor seus próprios argumentos, Alcibíades é submetido, mais uma vez, ao elenchos socrático (115a-116e). Estabeleceu-se pelo argumento (i) que quem pratica ações justas também pratica ações admiráveis; (ii) que ações admiráveis são boas e ações boas, vantajosas; (iii) logo, que ações justas são vantajosas. O jovem, por sua vez, é levado a perceber a sua falha em compreender o que é

72 Ambury, James M., 2011, p. 249. 
vantajoso e o que é desvantajoso, da mesma forma que não compreendia o que é justo e o que é injusto. Além disso, é preciso ressaltar que também os seus concidadãos, a quem ele pretendia aconselhar, não compreendiam tais questões (110d-112d, 118b119a).

\section{[116e2-4]}

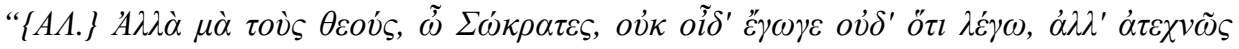

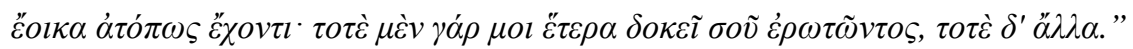

[ALC.] Mas pelos deuses, Sócrates! Eu não sei nem mesmo o que estou dizendo, mas pareço encontrar-me numa condição simplesmente absurda. Em uma ocasião, enquanto você perguntava, parecia-me uma coisa, e em outra, coisa diferente.

O elenchos nos faz perceber que o jovem ateniense era tomado não por uma simples ignorância, a do não saber, mas por uma dupla. A dupla ignorância reside no fato de Alcibíades não apenas ser ignorante a respeito do justo e do vantajoso, matérias de suma importância para quem pretende aconselhar a cidade, mas também julgar erroneamente conhecê-las.

De acordo com Sócrates (117e), os desprovidos de conhecimento não cometem erros, pois confiam a outrem aquilo que não sabem, ao passo que os males, por sua vez, são causados por aqueles que julgam conhecer o que não conhecem (118a). O filósofo faz uma crítica severa dessa ignorância, por considerá-la estúpida e censurável: a mais nociva e vergonhosa quando relativa às coisas mais importantes. É assim que Alcibíades passa pela experiência de aporia:

\section{[118b4-c1]}

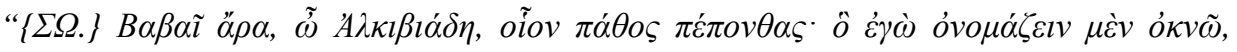

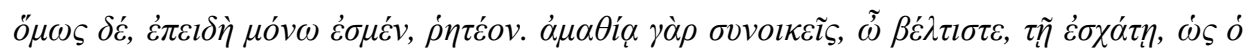

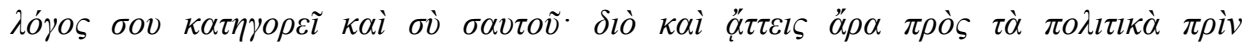

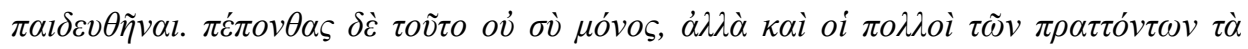
$\tau \tilde{\eta} \sigma \delta \varepsilon \tau \tilde{\eta} \varsigma \pi \delta ́ \lambda \varepsilon \omega \varsigma(\ldots) "$

[SÓC.] Ora, mas em que condição você se encontra, Alcibíades! Eu receio denominá-la; contudo, já que estamos sozinhos, devo dizê-lo. Pois você convive com a estupidez, excelente homem, com a extrema estupidez, como lhe acusa o seu argumento e você próprio. É por isso que você se lança como uma flecha na vida política antes de ter sido 
instruído. Você, contudo, não está sozinho nessa condição; muitos dos que se envolvem com a política nesta cidade também estão (...).

A aporia com que Alcibíades se deparou, no entanto, é o elemento essencial para que o jovem possa amadurecer intelectualmente, pois a consciência da ignorância nos torna seres capazes de investigação. Sendo assim, a aporia, embora signifique estar em impasse ou sem saída, não deve ser entendida como o final da linha, e sim como o ponto de partida para a investigação filosófica. De acordo com $\operatorname{Scott}^{73}$, após a exposição do seu falso saber, Alcibíades estaria preparado para assumir sua ignorância e diminuir sua arrogância na busca pelas respostas às questões apresentadas por Sócrates.

\section{8 - Discurso Real - elogio como estratégia de abordagem}

De acordo com Denyer ${ }^{74}$, o excesso de confiança de Alcibíades, no entanto, ainda o deixa cego perante a sua dupla ignorância, a qual ele não pretende considerar com tanta facilidade. Apesar de reconhecer a situação de ignorância em que se encontra, Alcibíades, nesse momento, não pretende se engajar no caminho da instrução, ou, como o denomina Sócrates (119a), no cuidado de si mesmo. Ao contrário, o jovem tem a intenção de se apoiar em sua nobreza e tirar vantagem dela, pois admite que os seus concidadãos possuam pouca ou nenhuma instrução política:

\section{[119b5-c1]}

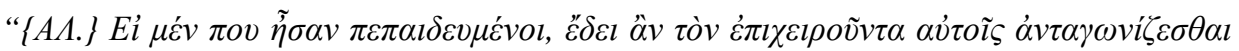

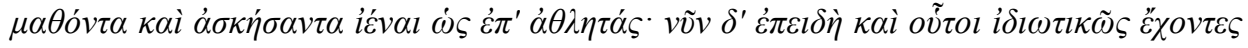

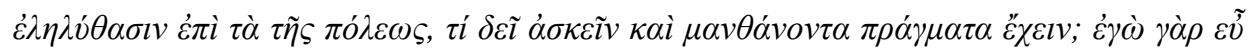

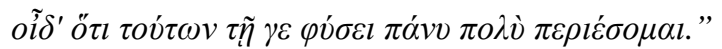

[ALC.] Se, suponho eu, fossem instruídos, seria preciso a quem tentasse contestar-lhes investir contra eles depois de ter aprendido e se exercitado, como se fosse investir contra atletas. Todavia, uma vez que também eles se engajaram na política da cidade como leigos, por que é preciso exercitar-me e ter o aborrecimento de aprender? Pois eu bem sei que serei muitíssimo superior a eles devido à minha natureza.

\footnotetext{
73 Scott, 2000, p. 88.

74 Denyer, 2001, p. 07.
} 
Com a resistência do jovem, Sócrates passa a utilizar outra estratégia de abordagem a fim de seduzir Alcibíades para o caminho da filosofia: o elogio, em longo discurso, dos reis lacedemônios e persas, os quais seriam os maiores rivais de Alcibíades (119c-120d, 124b). Denyer considera ${ }^{75}$ que a nova estratégia de Sócrates é arriscada, mas explora a vulnerabilidade de Alcibíades à retórica, apelando para seu senso de competitividade e para o seu respeito às estirpes.

Apesar de Sócrates utilizar-se, por vezes, do discurso longo, é preciso ressaltar que ele surge como necessidade na própria dinâmica do método dialógico e se encontra inserido em um contexto específico do diálogo. No caso do elogio dos reis lacedemônios e persas (121a3-124b6), o discurso longo é utilizado como estratégia de persuasão para que Alcibíades perceba as suas limitações e, por conseguinte, tenha em vista a necessidade do cuidado de si mesmo, ou seja, de instrução político-filosófica.

Nesse discurso, Sócrates traça uma comparação entre a criação e a educação dos reis rivais e as de Alcibíades, como também entre as suas riquezas e seu estatuto de nobreza, com o objetivo de destacar a inferioridade do jovem ateniense em relação aos recursos de seus maiores rivais. A atual condição de Alcibíades mostra-se risível diante desses adversários, contra quem não poderia competir no tocante aos recursos que tanto prezava entre os seus concidadãos atenienses, mas somente no cuidado de si mesmo:

\section{[123c3-124a4]}

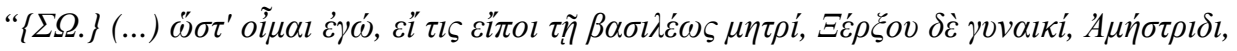

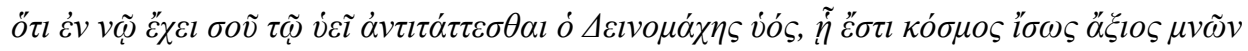

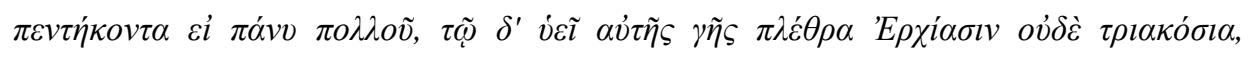

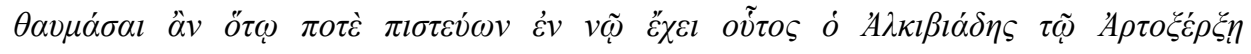

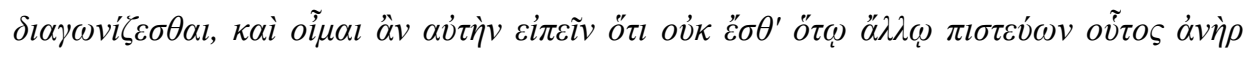

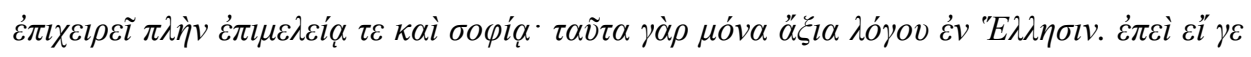

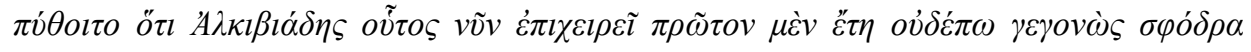

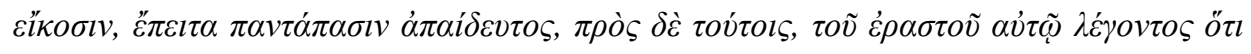

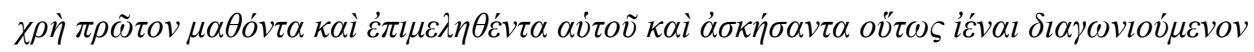

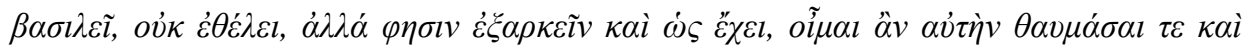

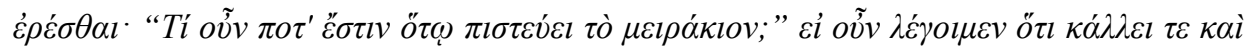

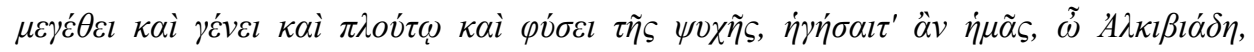

75 Denyer, 2001, p. 08. 


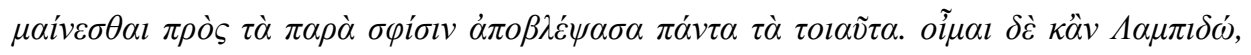

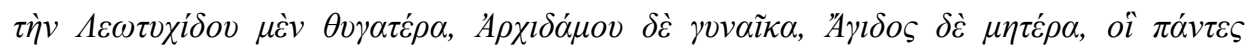

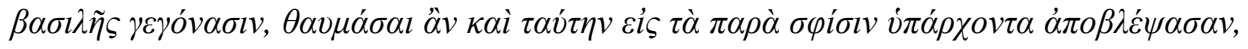

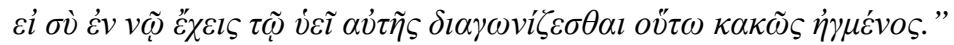

[SÓC.] (...) Segundo penso, se alguém dissesse a Améstride, mãe do rei e esposa de Xerxes, que Alcibíades, o filho de Dinômaca, pretendia competir com seu filho Dinômaca, cujos adornos talvez valham cinquenta minas, se muito, e Alcibíades, cujas terras em Érquia não chegam a equivaler a trezentos pletros - ela se perguntaria surpresa em que esse Alcibíades se fia a ponto de pretender rivalizar com Artaxerxes. E penso que ela diria que não há nada em que esse homem possa se fiar a não ser em cuidado e em sabedoria para tal investida, pois somente isso é digno de consideração entre os helenos. Contudo, se ela descobrisse que esse Alcibíades tem essa pretensão, em primeiro lugar, aos vinte anos de idade que ainda nem atingiu propriamente, e, em segundo lugar, sem ter qualquer instrução; e que, além disso, ele recusa ouvir seu amante quando lhe diz que é preciso antes se dedicar aos estudos e cuidar de si mesmo para então rivalizar com o rei, contra-argumentando que aquilo que ele tem já lhe é suficiente; nessas condições, penso que ela, tomada de espanto, perguntaria: "O que resta, então, para o jovem se fiar?" Se respondêssemos, então, que restam a beleza, a estatura, a linhagem, a riqueza e a natureza da alma, ó Alcibíades, ela julgaria que nós estamos delirando, ao compará-los com os do seu povo. Penso que Lampido igualmente, a filha de Leotiquides, mulher de Arquidamo e mãe de Ágis - todos eles foram reis seria tomada de espanto ao compará-los com os de seu povo, se você pretendesse rivalizar com o seu filho, estando nesta condição deplorável.

Segundo Wellman ${ }^{76}$, para Friedländer o elogio dos reis persas e lacedemônios, ou o chamado Discurso Real, serviria como uma introdução à necessidade do cuidado de si mesmo. Entretanto, para Wellman o propósito do Discurso Real estaria além dessa finalidade, visto que Alcibíades ainda não se encontraria preparado para compreender o significado da inscrição do oráculo de Delfos - conheça a si mesmo - e nem mesmo a extensão de sua própria ignorância. Já para Gordon ${ }^{77}$, a passagem do Discurso Real não possui objetivo laudatório, mas somente serviria ao propósito do conceito de ironia mimética (Miller, 1991):

\footnotetext{
76 Wellman, 1966, p. 13.

77 Gordon, 2003, p. 15.
} 
"Na ironia mimética, o interlocutor vê a si mesmo espelhado no discurso, dando a si mesmo (e também ao leitor) a oportunidade de refletir sobre quem ele é. Nessas ocasiões, o que Sócrates diz pode ou não refletir as suas próprias crenças, contudo sua utilização serve de gancho para comprometer o interlocutor (ou o leitor) e auxiliá-lo a vir de encontro a algum insight ou alguma realização. Aqui, as próprias ambições inapropriadas de Alcibíades lhe são refletidas nas descrições de Sócrates sobre o poder e as riquezas acumuladas pelos lacedemônios e pelos persas, e depois neutralizadas em contraste com o cuidado de si mesmo e a sabedoria. Sócrates utiliza seu conhecimento de Alcibíades a fim de proporcionar-lhe uma imagem de si mesmo.”

O Discurso Real, novamente de acordo com Wellman ${ }^{78}$, serviria como uma tentativa de estabelecer o verdadeiro comprometimento de Alcibíades com o argumento, ou seja, de aumentar o seu comprometimento intelectual e emocional com o objetivo de articulá-los com o ensinamento, visto que, até o momento, Alcibíades ainda não estaria comprometido o suficiente. O Discurso Real poderia ser entendido como uma tentativa de estabelecer a necessidade da deliberação conjunta na construção do conhecimento, estágio em que os interlocutores se encontrariam em uma relação de mútua confiança, situação ideal para o engajamento no processo educativo da filosofia.

\section{[124a7-b6]}

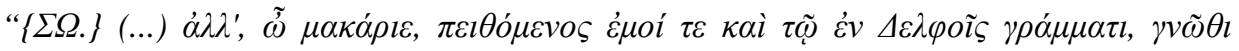

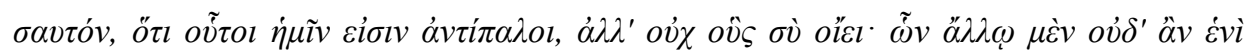

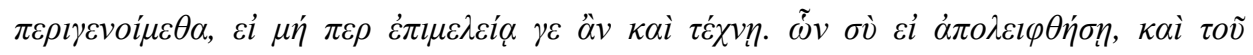

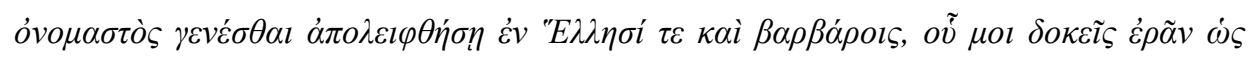

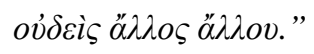

[SÓC.] (...) Mas, ó bem-aventurado, obedecendo a mim e à inscrição em Delfos, conheça a si mesmo! Pois são esses os nossos adversários, e não aqueles que você considerava. Não poderíamos superá-los em outra coisa senão em cuidado e em arte. Se você negligenciar isso, negligenciará também o seu futuro renome entre os helenos e os bárbaros, o que você me parece almejar como nenhum outro homem almeja alguma outra coisa.

Wellman ${ }^{79}$ ainda observa que a deliberação conjunta necessita de comprometimento e esforço de ambas as partes, o que exigiria também uma relação de

$\begin{array}{ll}78 & \text { Wellman, 1966, p. } 13 . \\ 79 & \text { Wellman, 1966, p. } 14 .\end{array}$


amizade entre elas. A partir desse momento do diálogo (124b-ss), Sócrates consegue enfim comprometer Alcibíades emocionalmente, ou seja, ambas as partes atingem um estágio mais profundo do relacionamento medido pelo Eros: mostram-se mais comprometidas com a deliberação conjunta, tanto intelectual quanto emocionalmente.

\section{9 - Faces espelhadas: cuidado de si mesmo e autoconhecimento}

Nesse momento do diálogo (124b-ss), Alcibíades aceita a sua condição desfavorável em face às suas aspirações políticas e reconhece a necessidade do

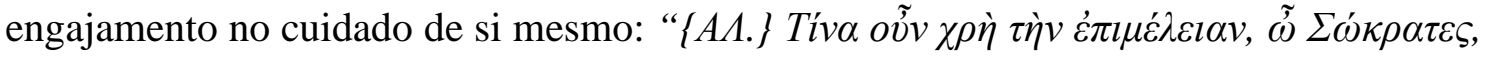

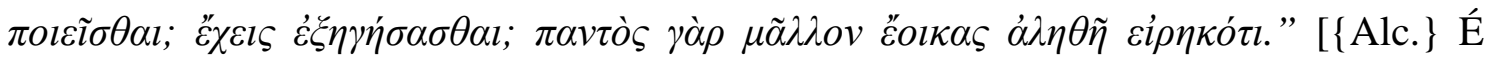
preciso colocar em prática, então, que tipo de cuidado, ó Sócrates? Pode explicar em maiores detalhes? Pois, mais do que todos, você parece ter dito a verdade.] (124b7-9).

Também há, nesse ponto (124b10-c3), o destaque, por parte de Sócrates, da necessidade da deliberação conjunta para que ambos possam se engajar no cuidado de si

mesmo. De acordo com Denyer ${ }^{80}$, é nesse momento que Alcibíades, por estar mais cooperativo e por apresentar um maior comprometimento, mostra-se mais preparado para ser introduzido em uma discussão filosófica mais sofisticada.

A partir de 128a, inicia-se uma investigação conjunta pela definição do cuidado de si mesmo e da arte que o rege. Segue-se do argumento a distinção entre o cuidado daquilo que diz respeito a alguém e o cuidado de alguém (de si mesmo): as pessoas, erroneamente, acreditam estar cuidando de si mesmas ao cuidarem do que lhes diz respeito, o que seria competência de uma arte distinta:

[128d11-e3]

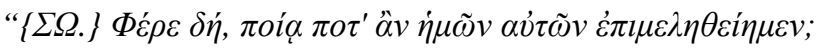

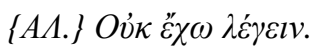

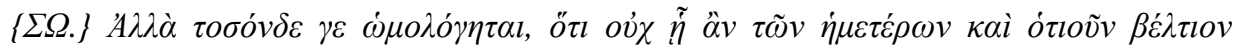

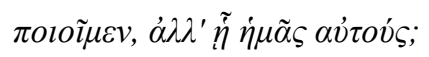

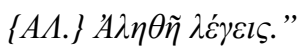

$80 \quad$ Denyer, 2001, pp. 08. 
[SÓC.] Vamos lá, então! Qual é a arte, pois, através da qual poderíamos cuidar de nós mesmos?

[ALC.] Não sei lhe responder.

[SÓC.] Mas estamos de acordo neste ponto, ao menos: que não é aquela através da qual tornaríamos melhor qualquer coisa que nos diz respeito, mas aquela através da qual tornaríamos melhores a nós mesmos. Não estamos?

[ALC.] É verdade o que você diz.

A definição do cuidado de si mesmo entrelaça-se, nesse ponto, com a definição do homem como alma. Três alternativas são colocadas sob investigação: (i) o homem como corpo; (ii) o homem como alma; ou (iii) o homem como o conjunto de ambos. Segue-se da investigação que o homem não pode ser corpo, visto que o corpo não pode governar a si mesmo (por ser ele governado); também não poderia ser corpo e alma, visto que ambos os elementos precisariam governar (mas o corpo não é capaz disso); portanto, o homem seria alma, visto que é o elemento que governa o corpo (129e9130c7).

Cuidar de si mesmo, portanto, pode ser definido como um processo de aprimoramento da alma, o que está diretamente relacionado à inscrição do templo de Delfos, tendo em vista que seria impossível o aprimoramento de alguém que não conhece a si mesmo (128e10-a1). A definição do cuidado de si mesmo, portanto, vincula-se diretamente com o reconhecimento e a compreensão do homem como alma (127e9-131a1).

Gordon ${ }^{81}$ argumenta que a demonstração prévia do orgulho de Alcibíades por sua beleza, sua riqueza e sua condição social culminou na descoberta da ignorância de si mesmo, etapa necessária para que o jovem ateniense pudesse ser introduzido, propriamente, no caminho da filosofia, que é o caminho do cuidado de si mesmo e do autoconhecimento. Segundo o estudioso ${ }^{82}$, o autoconhecimento é considerado necessário para se saber os valores que devem ou não ser cultivados. Os objetos de cuidado de Alcibíades, até então, eram as suas posses e não o seu "eu" verdadeiro, que é a sua alma. O caminho do autoconhecimento, portanto, culmina no cultivo da alma e suas respectivas virtudes, e Eros aparece como mediador desse caminho.

$\begin{array}{ll}81 & \text { Gordon, 2003, p. } 20 . \\ 82 & \text { Gordon, 2003, p. } 20 .\end{array}$ 
Ainda de acordo com Gordon ${ }^{83}$, o cuidado de si mesmo é fundamentalmente importante para o diálogo, pois ele serviria como ligação dos temas do autoconhecimento e do Eros: o autoconhecimento, de um lado, é mostrado como condição necessária para o cuidado de si mesmo, e o processo de como alguém alcança o cuidado de si mesmo e o autoconhecimento, de outro, é erótico, na medida em que o engajamento em uma relação amorosa recíproca, bem como o processo educacional envolvido no cuidado mútuo dos amantes, media o descobrimento do homem como alma.

Nesse ponto do diálogo (130d8-132a7), Sócrates mostra-se como o único amante verdadeiro de Alcibíades, na medida em que seu amor é direcionado não ao que diz respeito ao jovem - bens, status, beleza - mas sim ao que define Alcibíades como homem, ou seja, a sua alma:

\section{[131c5-131e4]}

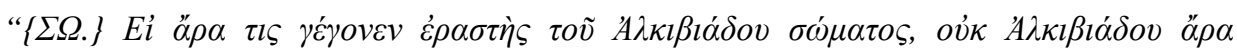
$\dot{\eta} \rho \alpha \dot{\sigma} \sigma \eta \eta \dot{\alpha} \lambda \lambda \dot{\alpha} \tau \imath v o \varsigma \tau \tilde{\omega} v \dot{A} \lambda \kappa \imath \beta i \alpha \dot{\alpha} \delta o v$.

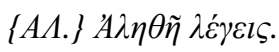

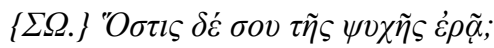

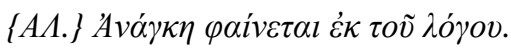

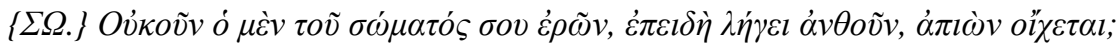

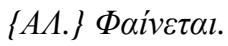

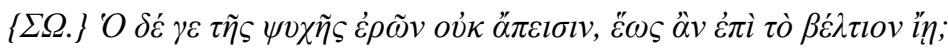

\{A1.\} Eikós $\gamma \varepsilon$.

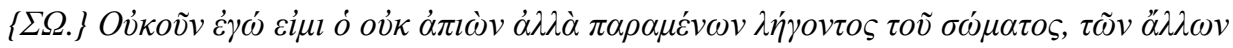
$\dot{\alpha} \pi \varepsilon \lambda \eta \lambda v \theta \dot{\sigma} \tau \omega v$.

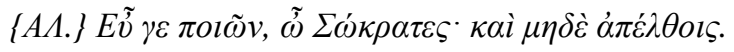

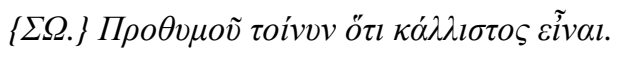

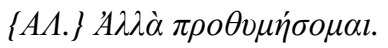

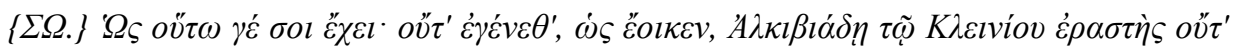

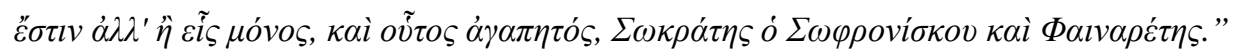

[SÓC.] Se, por conseguinte, alguém foi amante do corpo de Alcibíades, não amou Alcibíades, mas aquilo que diz respeito a Alcibíades.

[ALC.] Você diz a verdade.

[SÓC.] Mas quem o ama, ama a sua alma?

83 Gordon, 2003, p. 22. 
[ALC.] É forçoso pelo argumento.

[SÓC.] E não é verdade que, quando finda a flor de sua juventude, o amante de seu corpo parte para longe?

[ALC.] É claro.

[SÓC.] E o amante da sua alma, por sua vez, não partirá, enquanto você estiver em fase de aprimoramento, não é?

[ALC.] É plausível que sim.

[SÓC.] Eu sou, então, aquele que não parte, mas permanece ao seu lado mesmo findando a plenitude do seu corpo, enquanto os demais já se retiraram.

[ALC.] E fez bem, ó Sócrates. E espero que você não parta.

[SÓC.] Então, se esforce para que seja o mais belo possível!

[ALC.] Sim, me esforçarei!

[SÓC.] Eis a sua condição: não houve e não há, ao que parece, nenhum amante de Alcibíades, filho de Clínias, com exceção de um, que merece ser amado: Sócrates, filho de Sofronisco e Fenarete.

Contudo, como podemos cuidar de nós mesmos? Como podemos conhecer a nossa alma? São essas as indagações do jovem Alcibíades, a que Sócrates responde mediante o paradigma da visão (132d5-133c7). A metáfora da visão esclarece a similaridade com o caso da alma: tal como um espelho, um olho possui capacidade de reflexão. Para ver a si mesmo lhe seria necessário, entretanto, olhar para outro olho ou, mais precisamente, para a pupila, região em que se encontra a virtude do olho, a visão. Dessa mesma forma, quem pretende conhecer a si mesmo, isto é, a sua alma, deve olhar para outra alma, para a região em que se encontra a virtude da alma, a sabedoria (132c7133b11).

Wellman ${ }^{84}$ identifica a passagem do espelho como esclarecedora de como alguém pode, claramente, perceber a si mesmo: apenas quando se olha no profundo da alma do parceiro, especialmente na parte mais divina de sua alma, que é a inteligência ou potencial de conhecimento:

"É fundamental perceber que a analogia com a visão destina-se a manter o caráter funcional tanto do saber envolvido em conhecer a si mesmo e o objeto de conhecimento, o potencial de conhecimento da alma do amado. É essa conotação funcional que torna importante o reconhecimento de que a alma do outro está aberta quando atua como 
espelho; porque, ao contrário da visão, onde o objeto de minha vista é um objeto perceptivel, o objeto de meu conhecimento na alma do meu amado é forçosamente o processo de conhecer a si mesmo: 'sophia', o assento da 'phronesis' (133c), é cognoscível apenas como uma manifestação funcional.”

\subsection{0 - Relacionamento de papel duplo}

Nye ${ }^{85}$, por sua vez, argumenta que a Beleza é uma força inspiradora capaz de tornar possível a atividade criativa, a qual produzirá, em seu apogeu, ações virtuosas em um espectro maior, voltado à comunidade como um todo. Um relacionamento ideal, segundo Nye ${ }^{86}$, não é aquele em que os envolvidos cuidariam do outro na medida em que isso os auxiliaria em seus próprios interesses, mas aquele em que há um comprometimento em desenvolver uma inteira dimensão de hábitos e habilidades que tornassem o relacionamento o mais produtivo possível, voltado não apenas para o próprio bem, mas também para o bem de toda a rede de relacionamentos que cerca os amantes, que é a comunidade da qual são parte. Nesse sentido, Hooper ${ }^{87}$ argumenta que Platão enfraquece a noção da existência de um parceiro ativo e outro passivo nas relações amorosas:

“Cada parte aqui será um amante erótico do bem, e cada um será também o amado do outro, mas em nenhum papel eles serão meramente passivos. David Halperin (1986, 68) argumenta que, 'o talento da análise de Platão é que ela eliminou a passividade completamente: de acordo com Sócrates, ambos os parceiros tornam-se ativos, amantes desejosos; nenhum permanece como somente o objeto passivo do desejo’. Como amantes, cada parte irá se esforçar em direção ao bem, e como amados, cada um terá o dever de cuidar do outro e ajudá-lo em sua própria jornada. Como sugerido por Andrea Nye (1990, 148), o que Platão está detalhando aqui é a tentativa de duas (ou mais) partes de criar um espaço social em que cada um olhe a si mesmo e ao outro em uma maneira particular; e em que cada parte possua uma função particular, e há certos deveres inerentes a essas funções. É importante notar que essa não é uma

$85 \quad$ Nye, 1990, p. 140.

$86 \quad$ Nye, 1990, p. 143.

87 Hooper, 2012, p. 109. 
relação em que estamos preocupados, primeiramente, com o nosso próprio interesse; em vez disso, ela é fundamentalmente construída em torno da ideia do cuidar."

O engajamento em uma relação amorosa recíproca, portanto, pode ser denominado relacionamento de papel duplo, no qual ambos os parceiros são atores ativos da construção do relacionamento, bem como do seu aprimoramento. O processo educacional do autoconhecimento se relaciona não somente com a compreensão da minha alma no parceiro, mas também com a compreensão da alma humana que é parte não apenas do 'eu’ em você, mas do 'eu’ em nós. Um homem político, por excelência, pode ser considerado, portanto, como aquele capaz de compreender e intermediar as redes de relacionamento que fundamentam uma cidade a fim de torná-las virtuosas e produtivas ao máximo, direcionadas ao bem-comum.

Entretanto, de acordo com Denyer ${ }^{88}$, apesar das marcas do progresso intelectual de Alcibíades, Platão também marca no diálogo algumas indicações de que a sedução ainda não estaria completa e que, talvez, nunca estará: Alcibíades falha em aproveitar oportunidades intelectuais $(126 \mathrm{~d} 10,127 \mathrm{c} 2-3)$; continua a mostrar tendências à inatividade $(130 \mathrm{c} 7,135 \mathrm{e} 4)$, à evasão $(127 \mathrm{c} 10,130 \mathrm{~b} 10,131 \mathrm{c} 11,135 \mathrm{~d} 9)$, e, acima de tudo, permanece ávido em adotar o estilo prosaico da retórica sofística $(124 \mathrm{e} 7,125 \mathrm{c} 4-5$, 126e4-5, 129a5-6), mesmo ao professar que, a partir de então, adotaria os meios de Sócrates (135d8-11).

Hooper ${ }^{89}$, por sua vez, assinala que, apesar de o jovem ateniense ter compreendido a sua ignorância a respeito do bem e da justiça, ele teria sido incapaz de compreender a lição positiva de Sócrates - a necessidade do esforço no cuidado de si mesmo. Isso ocorreria, segundo Hooper ${ }^{90}$, por Alcibíades falhar em compreender a condição humana, isto é, que os homens ocupam uma posição intermediária entre a ignorância e a sabedoria. E, por fim, Gordon ${ }^{91}$ argumenta que o final agourento do diálogo poderia indicar a democracia ateniense como uma terceira parte nessa relação amorosa, ante a qual ambos, Alcibíades e Sócrates, poderiam sucumbir: o primeiro, por

$\begin{array}{ll}88 & \text { Denyer, 2001, pp. 08-09. } \\ 89 & \text { Hooper, 2012, p. } 115 . \\ 90 & \text { Hooper, 2012, p. } 114 . \\ 91 & \text { Gordon, 2003, p. } 29 .\end{array}$


dirigir seu eros à fascinação do poder em meio à maioria, seria engolido por ela; o segundo, por dirigir seu eros aos valores da vida filosófica, seria levado à morte ao confrontá-la. 


\section{4 - CONSIDERAÇÕES FINAIS}

\section{1 - Retrato da dimensão educativa da filosofia platônica}

O Alcibíades Primeiro pode representar um retrato inicial da dimensão educativa da filosofia platônica, ou seja, um movimento de atração para o caminho do autoconhecimento oferecido pela filosofia, caminho esse que se inicia a partir da aporia revelada pela refutação socrática. O diálogo trata da abordagem erótico-educativa de Sócrates junto ao jovem Alcibíades, com o objetivo de frear o seu impulso de se lançar precipitadamente na vida política e de prepará-lo para atingir a excelência, com um ensinamento adequado a quem pretende governar: o caminho da paideia filosófica.

O elenchos empreendido por Sócrates no diálogo possui o objetivo de dissolver a "verdade" aparente que Alcibíades julgava sobre si mesmo: a de que o status que sua linhagem, aparência e relações lhe conferiam na cidade fariam de si um cidadão proeminente na vida política, dotado dos melhores saberes que a assembleia e a cidade poderiam requerer. Era notória para Sócrates a ambição do jovem Alcibíades, que tinha a pretensão de se tornar um homem excelente na cidade, um verdadeiro $\kappa \alpha \lambda o ́ \varsigma \kappa \alpha \dot{\alpha} \gamma \alpha \theta o ́ \varsigma$. O papel de Sócrates no diálogo, portanto, seria o de revelar a Alcibíades o estado de sua ignorância, não aquela que concerne ao não saber, mas a pior de todas as formas de ignorância: o falso saber a respeito dos valores morais e políticos, e, sobretudo, a respeito de si mesmo:

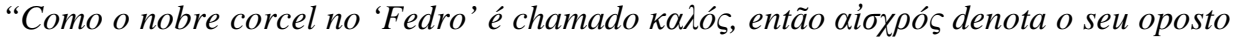
- ignóbil, feio, infame. Isso se torna especialmente importante mais tarde no

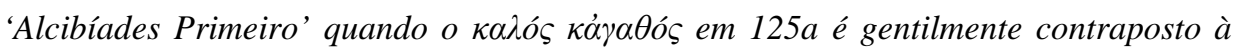

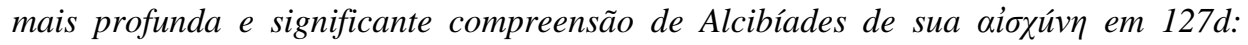

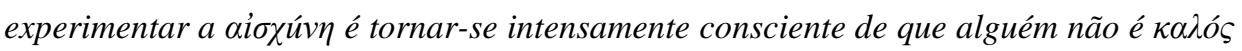

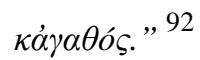

Além disso, ao interpelar Alcibíades, Sócrates lhe oferece não apenas uma elucidação de sua falsa sabedoria, mas também uma jornada em direção ao

92 Wellman, 1966, pp. 10-11. 
conhecimento que ele poderia obter de si mesmo e ao desenvolvimento intelectual que a filosofia poderia lhe proporcionar. Para que Alcibíades pudesse se tornar um verdadeiro governante na cidade, seria necessário, primeiramente, o cultivo de si próprio, ou seja, o cultivo das virtudes da alma para que lhe fosse possível desenvolver as habilidades intelectuais que lhe dariam a capacidade de governar a si mesmo e os demais.

\section{[134b7-c7]}

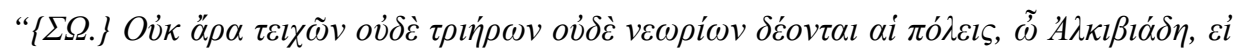

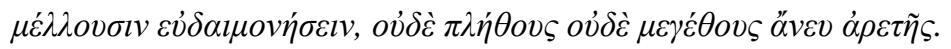

\{A1.\} Ov่ $\mu \dot{\varepsilon} v \tau o l$.

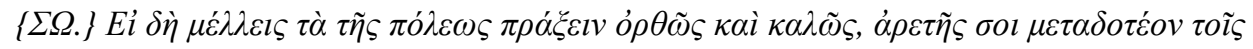

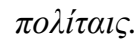

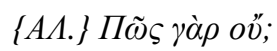

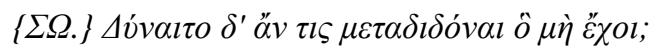

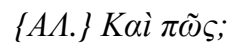

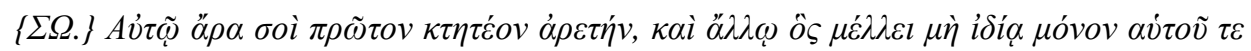

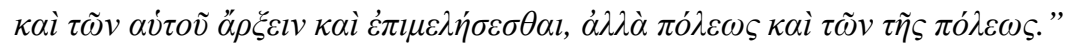

[SÓC.] Por conseguinte, se as cidades visam a felicidade, elas não necessitam de muralhas, nem de trirremes, nem de estaleiros, ó Alcibíades, nem de uma massa de gente, nem de magnitude, sem excelência.

[ALC.] Não mesmo.

[SÓC.] Se, então, você visa a prática política correta e bela, você deve transmitir a excelência aos cidadãos.

[ALC.] E como não?

[SÓC.] E alguém seria capaz de transmitir o que não possui?

[ALC.] Como o seria?

[SÓC.] Você deve, portanto, primeiro adquirir a excelência, assim como qualquer outro indivíduo que vise o comando e o cuidado, não somente de si próprio e do que lhe diz respeito no âmbito privado, mas também da cidade e do que lhe diz respeito.

Podemos dizer que o Alcibíades Primeiro é um diálogo que representa a dimensão erótico-educativa da filosofia platônica e que pode ser lido como o retrato do Eros socrático na interação com o jovem Alcibíades. Scott explica o Eros socrático como uma tática de Sócrates para se aproximar e deter o interesse de jovens atenienses proeminentes como Alcibíades. Nesse ponto, ele afirma que o diálogo tem certa semelhança com o Lísis: 
"Alcibíades, como Lísis, não é apenas jovem, nobre, belo e promissor, mas o seu desejo também se assemelha ao de Lísis no tocante à natureza política imodesta. O desejo por poder estimula ambas as personagens, e aqui novamente, Sócrates utiliza o desejo impassivel de um jovem por poder como catalisador em sua aproximação." 93

Há um contraste, nesse diálogo, entre as vidas política e filosófica e o grande desafio de Sócrates seria o de dissuadir o jovem Alcibíades do caminho da vida política e levá-lo à prática filosófica. Gordon ${ }^{94}$, por sua vez, assinala que o objetivo da sedução filosófica é o de substituir a ambição política de Alcibíades, seus pretendentes interesseiros e sua obsessão pelos seus recursos - riqueza, status, nobreza, beleza, etc pela filosofia, relacionamento amoroso genuíno e autoconhecimento. Sócrates, portanto, tem o objetivo de oferecer ao jovem ateniense uma oportunidade de mudança para o caminho da prática filosófica.

Segundo Renaud ${ }^{95}$, o Alcibíades Primeiro seria considerado por Olimpiodoro como um enfático diálogo erótico, e Sócrates, como uma eminente figura erótica. Como um amante divinamente inspirado, Sócrates é dito benevolente para com os seus favoritos: estaria preocupado, no caso do diálogo em questão, em cuidar do jovem Alcibíades e auxiliá-lo, através da dialética, a descobrir o bom e o belo de sua alma em um caminho de autoaperfeiçoamento oferecido pela filosofia.

De acordo com $\mathrm{Scott}^{96}$, o autoaperfeiçoamento está baseado na possibilidade de alguém causar mudanças em si mesmo durante o processo da prática das excelências. A prática socrática da liberdade, portanto, deve incluir a liberdade de alguém se transformar através de suas práticas. Sócrates, com sua abordagem erótico-educativa, age como um provocador de seus interlocutores, a fim de incitá-los a refletirem sobre suas atuações nos vários papéis que desempenham enquanto cidadãos livres e, ao refletirem sobre elas, terem a oportunidade de uma transformação radical em suas antigas concepções e desejos.

Assim, seria a dimensão educativa da filosofia, associada ao Eros socrático, o tema principal do diálogo, cujo objetivo culminaria no conhecimento de si mesmo e no

93 Scott, 2000, p. 81.

94 Gordon, 2003, p. 27.

95 Renaud, 2012, p. 195.

96 Scott, 2000, p. 102. 
cultivo da alma. A relação entre Sócrates e Alcibíades é representada como uma relação intensamente erótica e, ao olhar do Sócrates platônico, trata-se de uma relação intrinsecamente educativa, por abrir um mundo de possibilidades de mudança através da autorreflexão e participação ativa do interlocutor na construção do conhecimento.

Scott também defende a tese da inversão de papéis a que se sujeitam Sócrates e Alcibíades/Lísis nos respectivos diálogos. A inversão de papéis diz respeito ao estado inicial de Sócrates como perseguidor dos jovens e o estado final dos jovens como perseguidores de Sócrates, em busca pelo desenvolvimento intelectual que a filosofia poderia lhes oferecer em benefício de sua carreira futura. ${ }^{97}$ Contudo, essa inversão de papéis entre Sócrates e Alcibíades pode ser considerada não como uma simples reversão de papéis, mas sim como ensejo para ambos se entrelaçarem em um relacionamento recíproco de papel duplo, amantes e amados ao mesmo tempo.

\section{[135d7-10]}

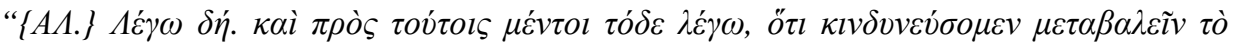

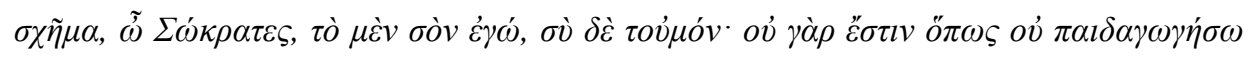
$\sigma \varepsilon \dot{\alpha} \pi \dot{\partial} \tau \tilde{\eta} \sigma \delta \varepsilon \tau \tilde{\eta} \varsigma \dot{\eta} \mu \varepsilon \dot{\varepsilon} \rho \alpha \varsigma, \sigma \grave{~} \delta^{\prime} \dot{v} \pi^{\prime} \dot{\varepsilon} \mu o \tilde{v} \pi \alpha l \delta \alpha \gamma \omega \gamma \dot{\eta} \sigma \eta !$

[ALC.] Assim responderei. E, além disso, ainda digo o seguinte: que haverá a possibilidade de trocarmos os papéis, ó Sócrates, eu assumindo o seu, e você, o meu; pois é impossível que, a partir de hoje, eu não me dedique a sua companhia como se fosse seu preceptor, e que você não seja acompanhado por mim como seu preceptor.

Já Wellman ressalta a positividade do conceito do Eros socrático e sua relevância para a filosofia, por ser o eros mediador das duas almas que se encontram e se entrelaçam em um relacionamento genuíno voltado ao aprimoramento intelectual e emocional. O autor recorre ao Banquete de Platão e ao de Xenofonte para ilustrar essa imagem do Eros socrático:

"A relação amorosa descrita por Alcibíades é uma relação na qual os parceiros manifestam e mantêm a sua integridade em todos os níveis da sociedade humana. Como observa Xenofonte em seu 'Banquete': "não há nenhuma sociedade humana 
significativa sem amor” [viii, 13]. A compulsão do Sócrates erótico é a compulsão da boa fé e probidade que necessariamente se obtém na relação entre os amantes.” 98

O Eros socrático pode ser visto, portanto, não somente como uma estratégia de abordagem de Sócrates, mas também como o princípio da philia fundamental para que ocorra o diálogo de orientação filosófica. $\mathrm{O}$ estado de philia entre os interlocutores é o responsável pela sinceridade e colaboração mútua em busca do conhecimento, visto que um estado de animosidade ou de indiferença entre os interlocutores jamais lhes permitiria o engajamento em uma investigação que visa uma deliberação conjunta. ${ }^{99}$

Mais do que uma relação baseada na philia, espera-se que o encontro entre os interlocutores resulte em um relacionamento de amor recíproco, no qual ambos devem cultivar a si mesmos e zelar, como amantes, pelo aprimoramento do amado. Ao contrário dos demais perseguidores de Alcibíades, como salientado anteriormente, Sócrates não perseguia, baseado em interesses próprios, o corpo de Alcibíades e o que lhe é relativo, e sim a sua alma, pois é o aprimoramento da alma a preocupação máxima da filosofia.

O amor filosófico de Sócrates caracteriza-se como profundamente educativo, tendo em vista o seu objetivo final de cultivar o desenvolvimento da alma de seu amado (131c5-d5). O amor filosófico, portanto, concerne ao amor pela alma, e não pelo corpo e o que lhe é relativo. Isso ocorre em razão de sua efemeridade, pois a beleza da mocidade não é eterna, mas se esvanece, e os interesses estão sempre em mudança: assim como os amantes dessa beleza abandonam o ser amado quando cessa a flor de sua mocidade, também o abandonam quando não mais usufruem dos seus benefícios. $\mathrm{O}$ amor ao corpo e ao que lhe é relativo, por conseguinte, cultiva somente o prazer pela aparência e por vantagens pessoais, enquanto o amor à alma, em contrapartida, cultiva o verdadeiro ser e o seu aprimoramento.

Entretanto, também é preciso ressaltar a importância e o perigo que poderia representar a posição de Alcibíades na cidade, pois o jovem possuía todos os atributos necessários para se tornar um homem de influência na vida política da cidade. $\mathrm{O}$

\footnotetext{
98 Wellman, 1966, p. 6.

99 Cf. Platão, Górgias, 457c-458b.
} 
Alcibíades Primeiro pode ser considerado um diálogo educativo também pelo objetivo de Sócrates de dissuadir o impulso do jovem ateniense de trilhar o caminho político sem preparo prévio - tendo em vista os males que isso poderia causar - e o de direcioná-lo ao caminho da filosofia, isto é, do autoaprimoramento.

É esse aprimoramento das virtudes da alma de Alcibíades que visa Sócrates em sua abordagem erótico-educativa, pois somente através da educação da alma em vista da virtude seria possível ao jovem governar a cidade como o verdadeiro $\kappa \alpha \lambda o ́ \varsigma \kappa \alpha \dot{\alpha} \alpha \alpha \theta o ́ \varsigma$ que pretendia ser: na visão do Sócrates platônico, o homem político por excelência deveria necessariamente trilhar o caminho da paideia filosófica e ser o agente transformador da realidade política. A Alcibíades (e também a Sócrates), no entanto, o final do diálogo já lhe(s) indica um prognóstico pessimista de um futuro (in)determinado.

\section{[135e1-8]}

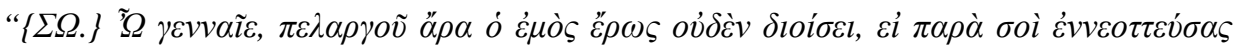

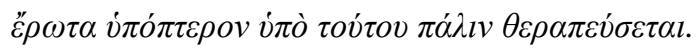

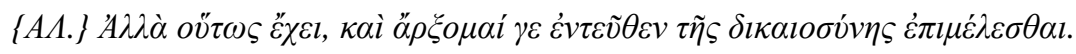

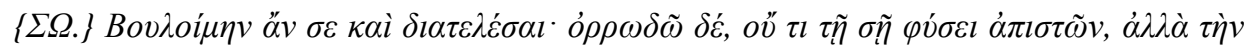
$\tau \tilde{\eta} \varsigma \pi \dot{\lambda} \varepsilon \epsilon \omega \varsigma \dot{o} \rho \tilde{\omega} v \dot{\rho} \dot{\omega} \mu \eta v, \mu \grave{\eta} \dot{\varepsilon} \mu o \tilde{v} \tau \varepsilon \kappa \alpha i ̀ ~ \sigma o \tilde{v} \kappa \rho \alpha \tau \dot{\eta} \sigma \eta . "$

[SÓC.] Ó nobre amigo, o meu amor, portanto, em nada diferirá do da cegonha, se, depois de ter incubado um amor alado em você, este for objeto, em troca, de seu cuidado.

[ALC.] Mas assim será. E, a partir de agora, começarei a cuidar da justiça.

[SÓC.] Eu gostaria muito que você cumprisse isso. Mas temo, não por desconfiar de algum modo de sua natureza, mas por observar o poderio da cidade, que este domine a mim e a você. 


\section{PARTE II}

TRADUÇÃO

ALCIBÍADES PRIMEIRO DE PLATÃo 


\section{$\mathrm{A} \Lambda \mathrm{KIBIA} \Delta \mathrm{H} \Sigma *$}

\section{St. II $\quad \Sigma \Omega$ KPATH $\Sigma \quad$ A $\Lambda$ KIBIA $\Delta H Z$}

p. 103

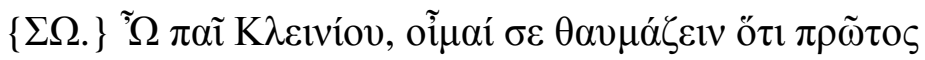

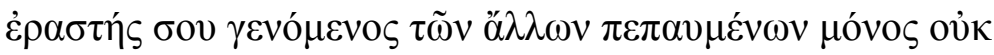

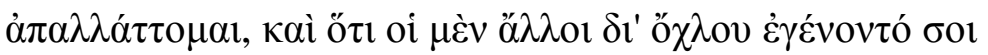

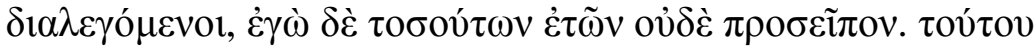

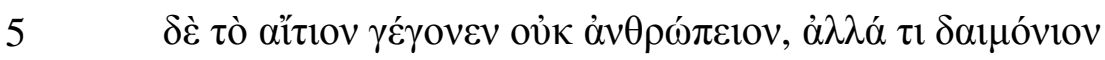

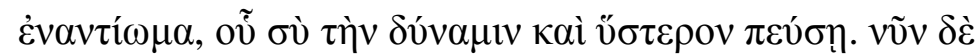

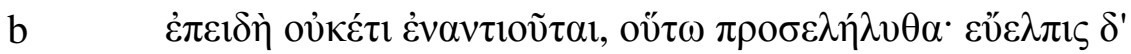

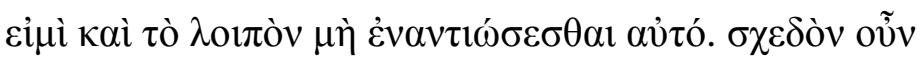

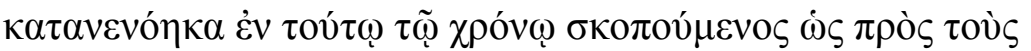

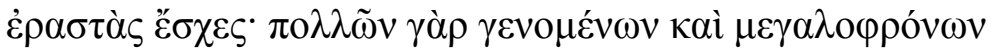

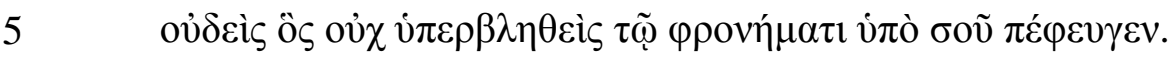

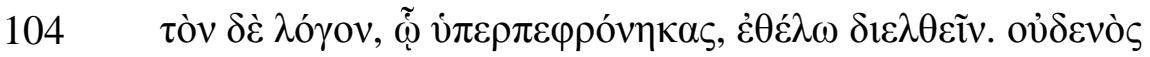

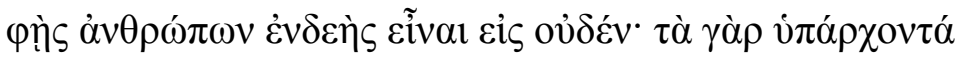

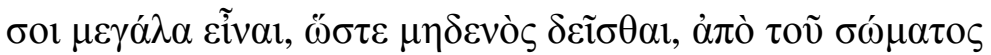

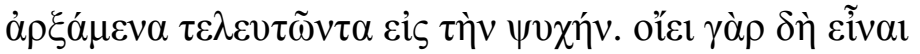

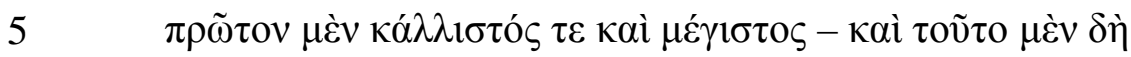

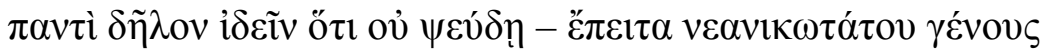

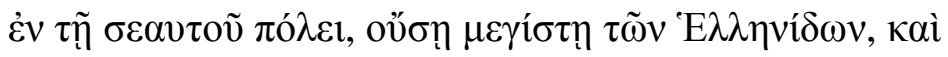

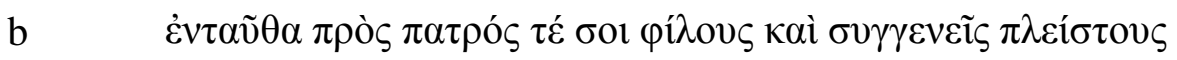

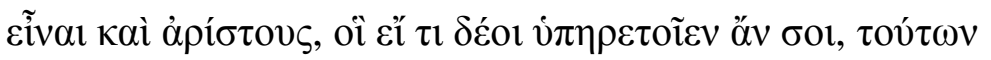

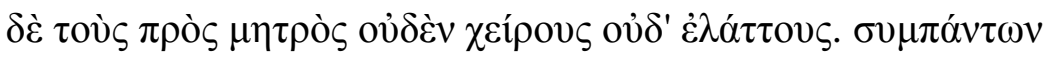

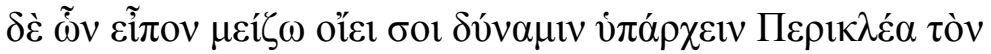

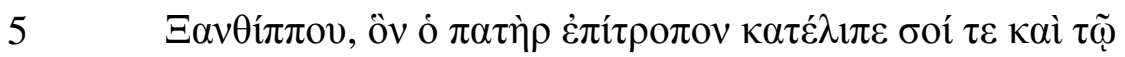

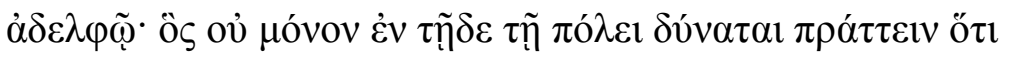

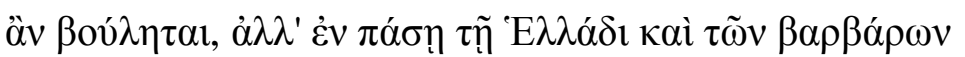




\section{ALCIBÍADES}

SÓCRATES ALCIBÍADES

[SÓC.] Ó filho de Clínias, penso que você se admira por que eu, tendo sido 103 seu primeiro amante, sou o único a não ter me afastado de você enquanto os demais o abandonaram, e por que eles o importunavam com suas conversas, enquanto eu nada the declarei em muitos anos. A causa disso não tem sido de natureza humana, e sim certo impedimento divino, cujo poder você conhecerá também futuramente. Agora, já que não mais se opõe, nessas condições me dirijo a você, pois tenho a esperança de que ele não há de impedir doravante. Bem, em todo esse tempo eu percebi, ao observá-lo de longe, como você se comportou em relação aos seus amantes: embora fossem muitos e altivos, não há nenhum que, uma vez sobrepujado pela sua altivez, não tenha fugido. A razão pela qual você se sente superior eu desejo lhe expor. Você diz não necessitar de ninguém para nada, pois é tão elevada a sua condição que não necessita de nada, a começar pelo corpo e a terminar na alma. Pois considera, em primeiro lugar, ser o maior e o mais belo - é evidente para todos que o vêem que você não está mentindo - e, em segundo lugar, ser da família mais proeminente de sua cidade, que é a maior dentre as cidades helênicas; e, da parte de seu pai, você julga ter inúmeros amigos e parentes excelentes, os quais se colocariam à sua disposição caso necessitasse de algo, e, da parte de sua mãe, inúmeros outros em nada inferiores. Mas, dentre tudo aquilo que citei, você considera que o seu maior poderio provém de Péricles, filho de Xantipo, seu tutor e de seu irmão por força de seu pai; ele que não apenas nesta cidade é capaz de fazer o que desejar, mas também em toda a Hélade e, entre os bárbaros, 


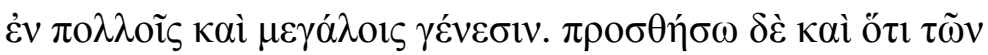

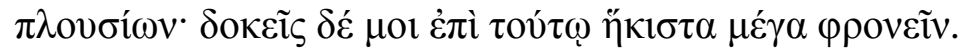

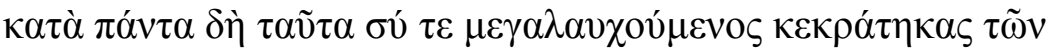

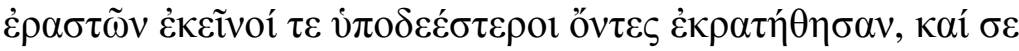

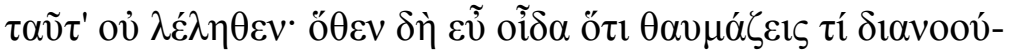

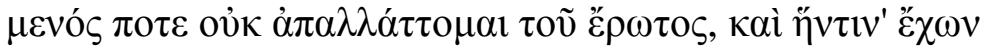

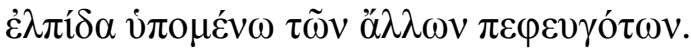

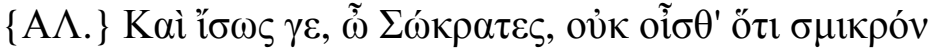

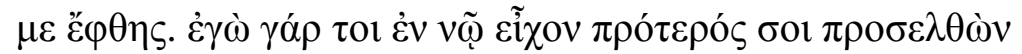

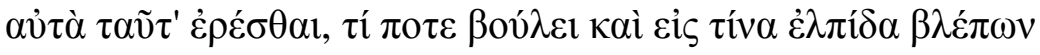

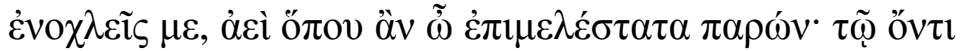

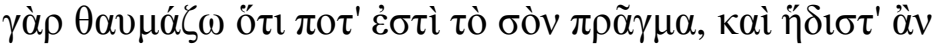
$\pi v \theta o i ́ \mu \eta v$.

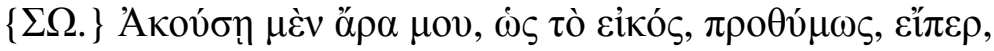

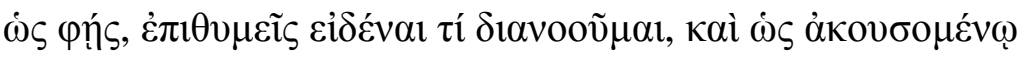

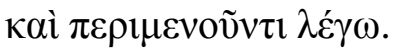

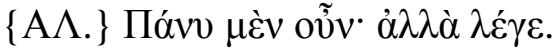

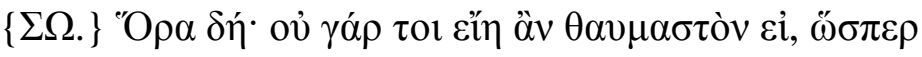

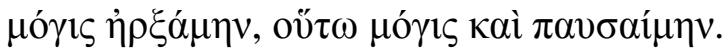

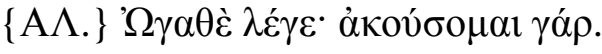

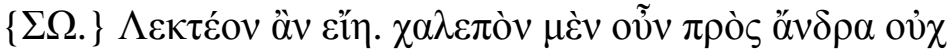

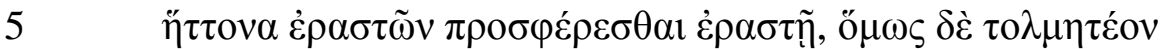

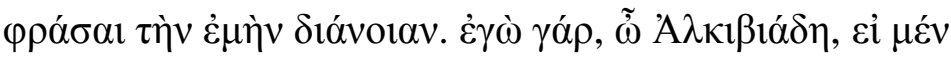

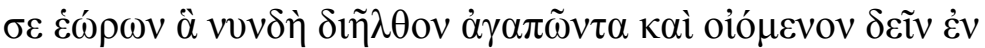

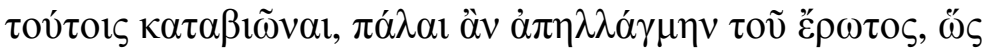

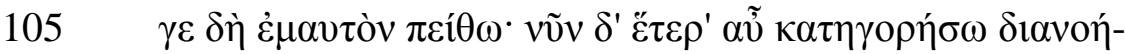

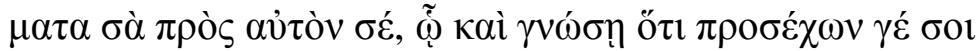

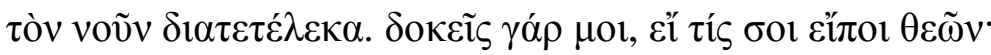

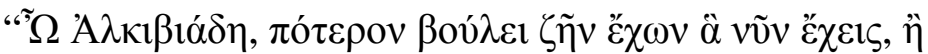


em muitas povoações grandiosas. Acrescentarei também que você está entre os abastados; mas, quanto a isso, você me parece ser menos arrogante. Em vista de tudo isso, vangloriando-se, você prevaleceu sobre os seus amantes, e aqueles, por serem inferiores, foram então superados, fato que você não ignora. É por essa razão que eu bem sei que você se pergunta espantado por qual motivo eu não me livro deste amor, e com qual esperança eu resisto, ao passo que os demais se retiraram.

[ALC.] Mas talvez, Sócrates, você não saiba que me antecipou por pouco. Pois eu tinha, de fato, a intenção de me aproximar de você para perguntar estas mesmas coisas: o que tanto deseja e com qual esperança me perturba estando sempre presente da maneira mais cuidadosa onde quer que eu esteja. $\mathrm{Na}$ verdade, eu me pergunto qual é o seu problema e ficaria muito agradecido de saber.

[SÓC.] Então me escutará de bom grado, ao que parece, se é verdade que, como você diz, deseja descobrir o que penso; e eu vou lhe contar esperando que me escute com perseverança.

[ALC.] Certamente. Mas vamos, diga-me!

[SÓC.] Observe então! Pois não seria admirável se, da mesma maneira que e dei o primeiro passo com dificuldade, dificilmente eu me interrompesse.

[ALC.] Fale, bom homem, que eu lhe escutarei!

[SÓC.] Devo dizê-lo então. Pois bem, é difícil para o amante lidar com um homem que não cede aos amantes, contudo devo ter ousadia para expor o meu pensamento. Pois se eu o visse, Alcibíades, satisfeito com aquilo que agora mesmo expus e convencido de que devia passar a vida nessa condição, há muito tempo eu teria me afastado deste amor, como tento convencer a mim mesmo. Mas agora, diante de você aqui, irei denunciar mais uma vez outros desígnios seus, pelos quais reconhecerá que tenho passado a minha vida dedicando-me a você. Ao que me parece, se algum deus lhe perguntasse: "ó Alcibíades, você desejaria viver com aquilo que já possui, $\mathrm{ou}$ 


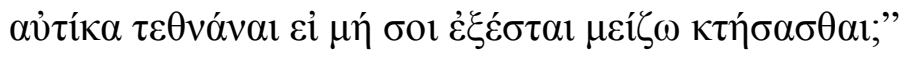

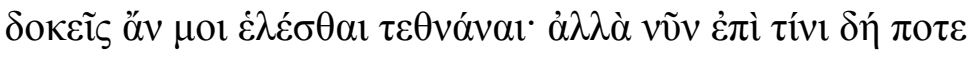

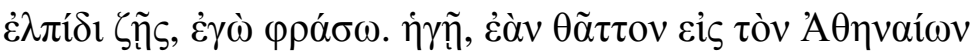

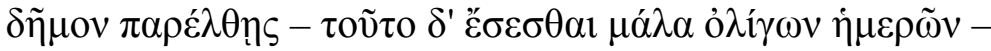

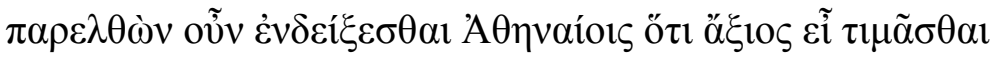

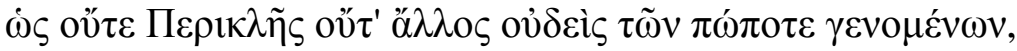

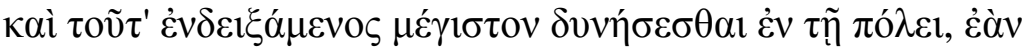

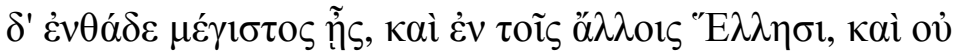

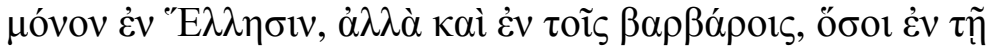
$\alpha$

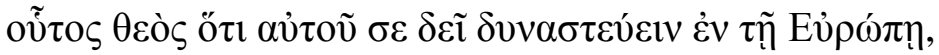

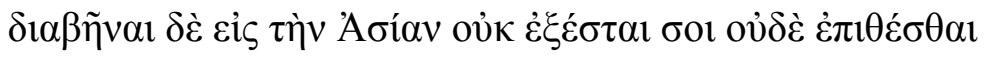

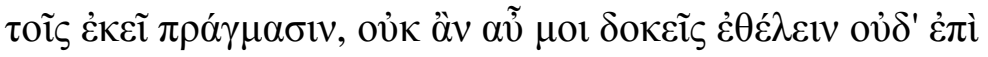

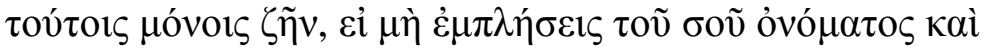

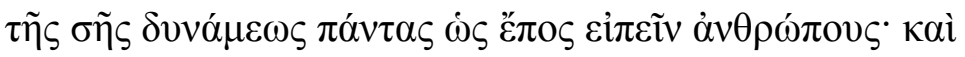

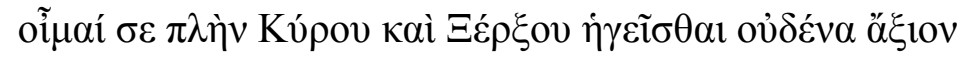

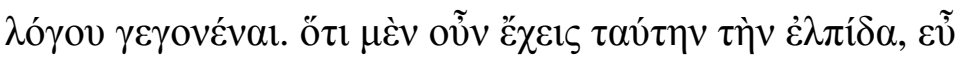

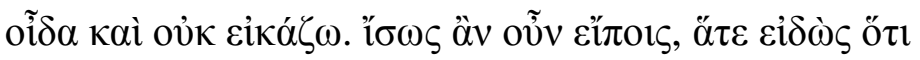

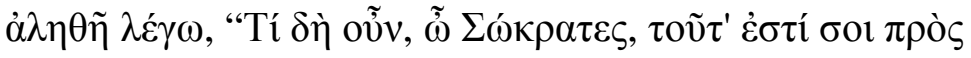

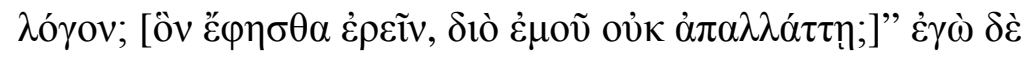

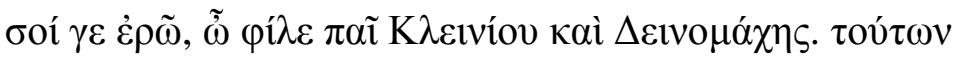

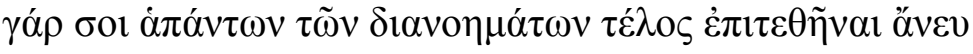

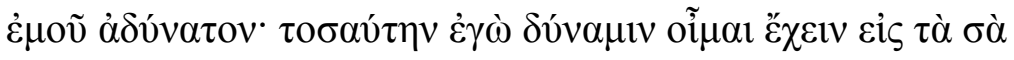

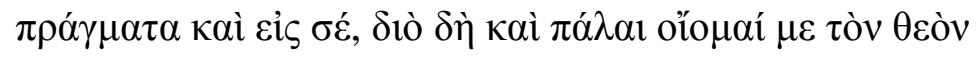

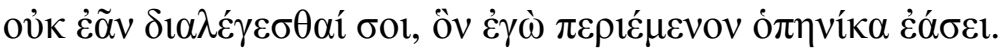

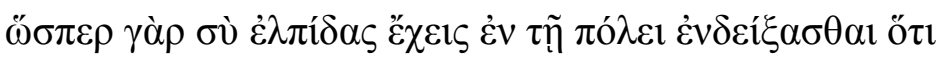

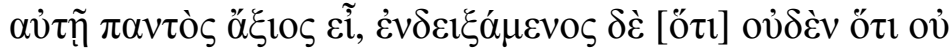

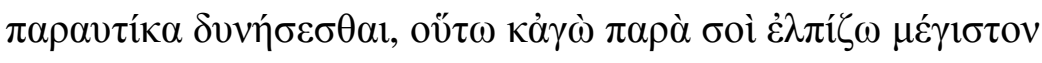

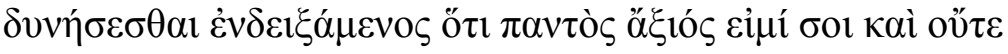


morrer, se não lhe fosse possível adquirir bens maiores?", suponho que você preferiria morrer. Todavia, com qual expectativa você agora vive, eu revelarei. Você pensa que, assim que se apresentar diante do povo ateniense - o que será possível em pouquíssimos dias - provará, diante deles, que é digno de ser honrado como nem mesmo Péricles foi nem qualquer outro homem até então. E, ao provar isso, pensa que será o homem mais poderoso na cidade e, se nela for o mais poderoso, também o será nas demais cidades da Hélade; e não apenas na Hélade, mas também entre os bárbaros que habitam o nosso continente. E se aquele mesmo deus novamente lhe dissesse que você devia exercer o poder aqui na Europa, mas que não the seria possível atravessar para a Ásia nem intervir nos assuntos de lá, pareceme que não se contentaria em viver somente com isso, enquanto não impregnasse toda a humanidade, por assim dizer, com o seu nome e poder. E penso que, com exceção de Ciro e de Xerxes, você não considera ninguém digno de mérito. Portanto, que você possui tal expectativa, eu tenho certeza e não conjeturo. Talvez você pudesse dizer, então, ciente de que eu digo a verdade: "Mas o que isso, Sócrates, tem de relevante para a discussão, quando prometia me explicar por que razão você não me abandona?’. E eu vou responder, ó caro filho de Clínias e de Dinômaca: é que a realização de todos esses seus planos é impossível sem mim. Eu julgo possuir tamanha influência sobre suas coisas e sobre você, que, em razão disso, penso que por muito tempo o deus não me permitia dialogar com você, e eu fiquei esperando o momento de sua permissão. Assim como você espera provar para a cidade que merece todas as honrarias da parte dela, ao ter mostrado que não há nada que agora não seja capaz, também eu espero que eu seja capaz de ser o homem mais influente sobre você, ao ter mostrado que mereço todas as honrarias de sua parte, e que nem 


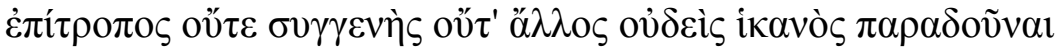

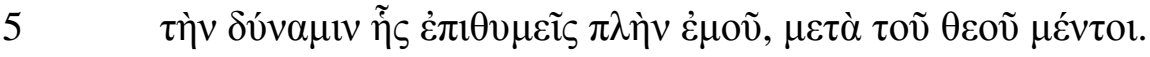

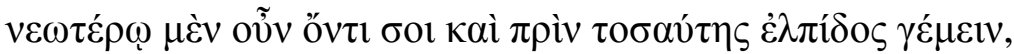

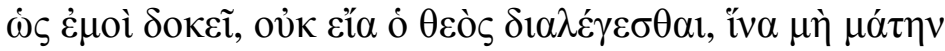

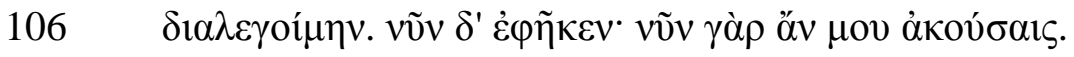

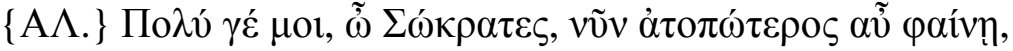

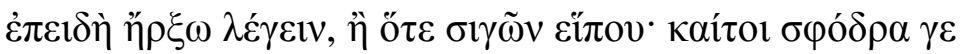

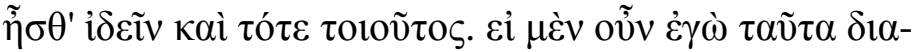

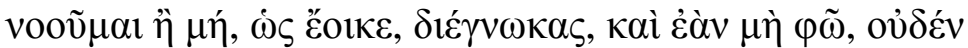

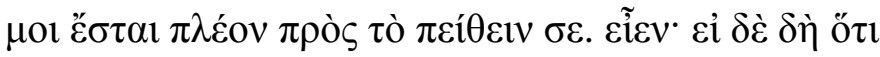

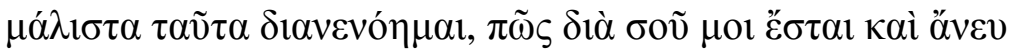

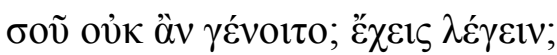

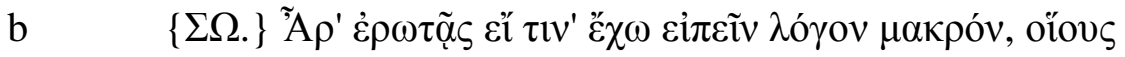

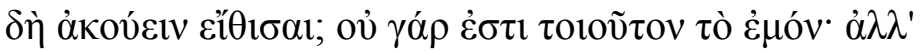

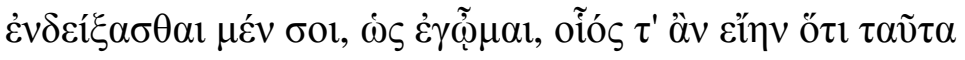

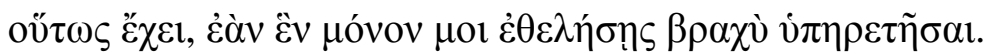

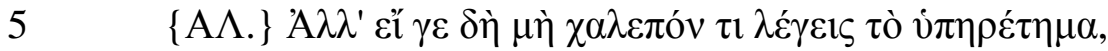
$\dot{\varepsilon} \theta \varepsilon ́ \lambda \omega$.

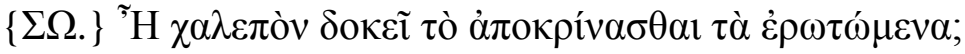

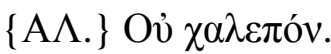

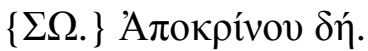

$10 \quad\{\mathrm{~A} \Lambda.\}{ }^{\prime} \mathrm{E} \rho \omega ́ \tau \alpha$.

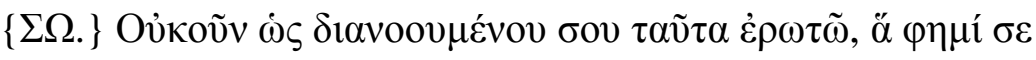
c $\quad \delta 1 \alpha \nu o \varepsilon i \tilde{\sigma} \theta \alpha$;

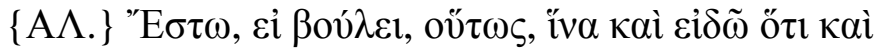

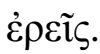

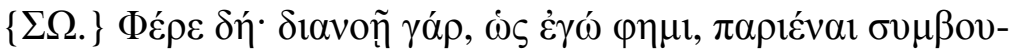

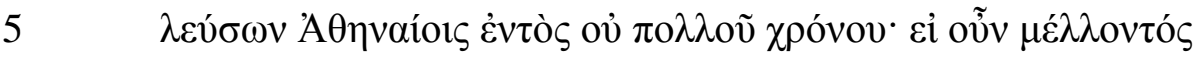


tutor, nem parente, nem qualquer outro homem tem a competência para lhe oferecer a capacidade que almeja, exceto eu - com a ajuda do deus, decerto. Quando você era mais jovem e ainda não estava insuflado com tamanha expectativa, ao que me parece, o deus não me permitia dialogar com você, a fim que não fosse em vão o nosso diálogo. Mas agora ele me fez essa concessão, pois neste momento você me ouviria.

[ALC.] Mas agora, Sócrates, depois que começou a falar, você me parece muito mais extraordinário do que quando me seguia em silêncio, embora já fosse bastante extravagante de se ver então. Se eu planejo tais coisas ou não, ao que parece, você já está decidido sobre isso e, ainda que eu negue, não há nada mais que eu possa fazer para convencê-lo. Que seja então! Se é isso mesmo o que planejo sobretudo, como poderei obtê-lo com a sua ajuda e sem ela não o obteria? Pode me dizer?

[SÓC.] Acaso você pergunta se eu posso fazer um longo discurso como aqueles que você está habituado a ouvir? Não, pois não é o meu costume. Mas penso que eu seria capaz de lhe provar que isso é verdade, se você consentir em me fazer um pequeno favor apenas.

[ALC.] Se não for deveras difícil o favor que me pede, posso consenti-lo.

[SÓC.] E lhe parece difícil responder algumas perguntas?

[ALC.] Não é difícil.

[SÓC.] Então responda!

[ALC.] Pode perguntar.

[SÓC.] Eu devo lhe perguntar, então, como se você planejasse o que eu afirmo que você está planejando?

[ALC.] Que assim seja, se lhe apraz, para que dessa forma também eu saiba o que você irá dizer.

[SÓC.] Então seja! Você planeja, como eu venho dizendo, apresentar-se perante os atenienses para aconselhá-los em breve. Se então, estando você prestes a 


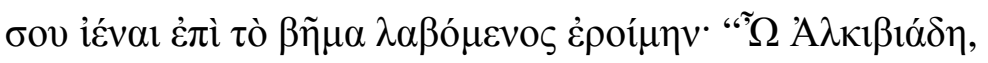

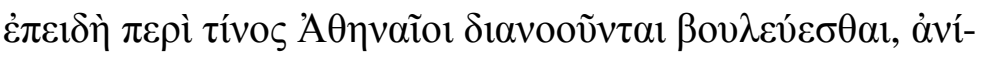

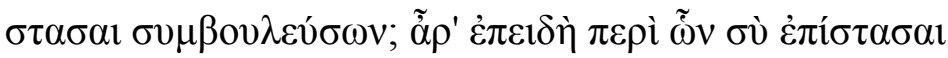

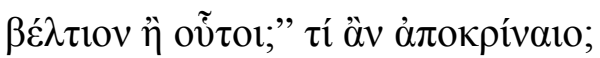

d

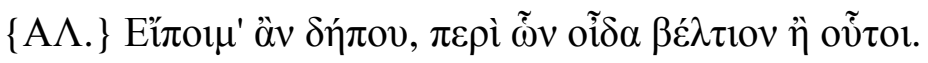

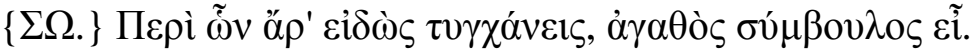

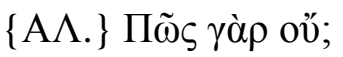

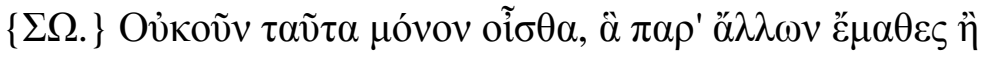
$\alpha u ̉ \tau o ̀ \varsigma ~ \dot{\varepsilon} \xi \eta \tilde{v} \rho \varepsilon \zeta ;$

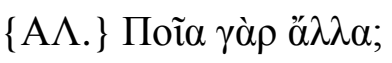

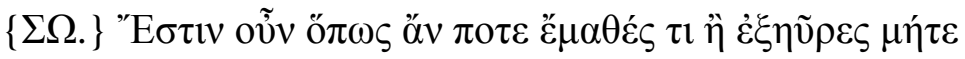

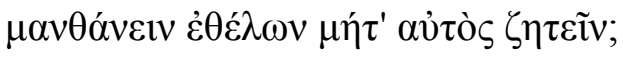

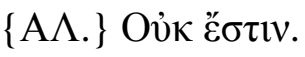

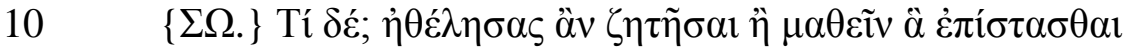
ఝ̋ov;

$\{$ A $\Lambda$.$\} O \delta \tilde{\eta} \tau \alpha$.

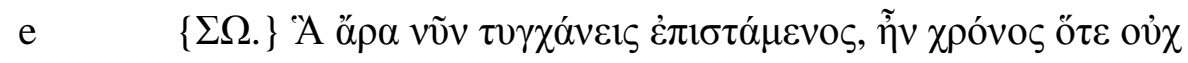

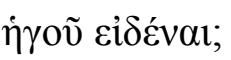

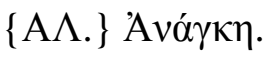

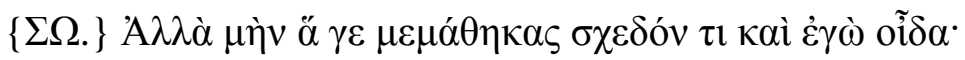

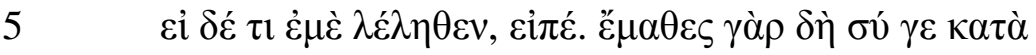

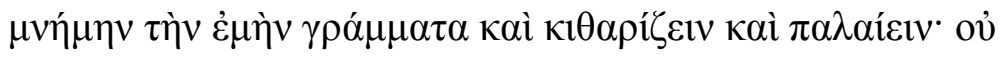

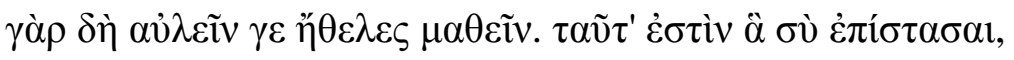

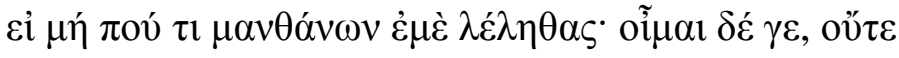

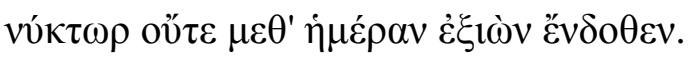

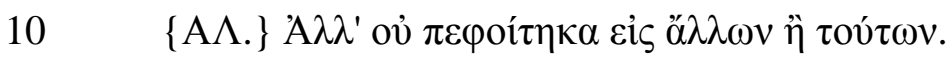

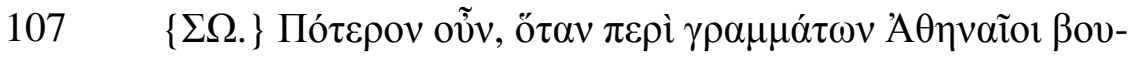

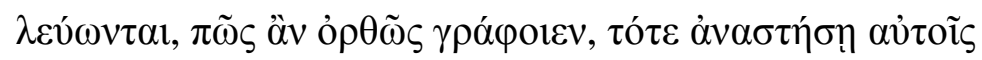
$\sigma v \mu \beta о v \lambda \varepsilon v ́ \sigma \omega v$ 
subir à tribuna, eu o surpreendesse com a seguinte pergunta: "ó Alcibíades, você se levanta para dar conselhos aos atenienses, quando eles planejam deliberar sobre que assunto? Acaso sobre o que você possui maior conhecimento do que eles?" O que responderia?

[ALC.] Eu diria que, com certeza, sobre os assuntos que eu conheço melhor $d$ do que os demais.

[SÓC.] Portanto, você é um bom conselheiro a respeito dos assuntos que já conhece.

[ALC.] E como não seria?

[SÓC.] E porventura você conhece somente aquelas coisas que aprendeu junto aos demais ou descobriu por si mesmo?

[ALC.] Que outras coisas eu conheceria?

[SÓC.] É possível então que tenha aprendido ou descoberto algo sem desejar aprender ou sem investigar por conta própria?

[ALC.] Não, não é.

[SÓC.] E então? Teria você desejado saber ou aprender o que julgava conhecer?

[ALC.] É claro que não.

[SÓC.] As coisas que agora você conhece, houve um tempo em que não $\mathrm{e}$ presumia conhecê-las?

[ALC.] Necessariamente.

[SÓC.] Com efeito, eu também sei mais ou menos aquilo que você aprendeu. Mas se eu me esquecer de algo, avise-me! Você aprendeu, se me recordo bem, as letras, a tocar cítara e a lutar. Quanto a tocar aulo, não quis aprender. Essas são as matérias que conhece, a não ser que, de alguma maneira, tenha aprendido algo que eu não tenha percebido. Mas penso que nem de noite e nem de dia você saiu de casa.

[ALC.] Realmente eu não frequentei outras matérias além dessas.

[SÓC.] Então, quando os atenienses deliberarem sobre as letras, sobre como escreveriam corretamente, será nessa ocasião que você se apresentará diante deles para aconselhá-los? 


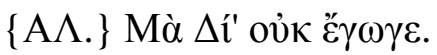

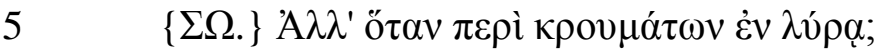

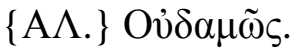

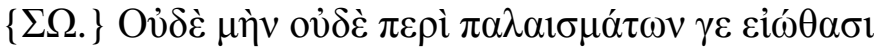

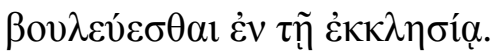

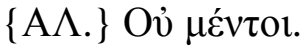

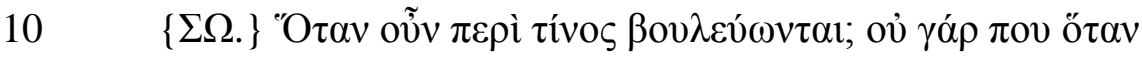

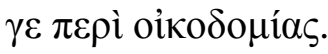

$\{\mathrm{A} \Lambda$.$\} Ov̉ \delta \tilde{\eta} \tau \alpha$.

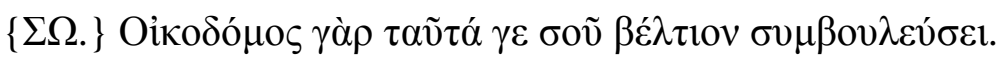

b $\quad\{$ A $\Lambda$.$\} Naí.$

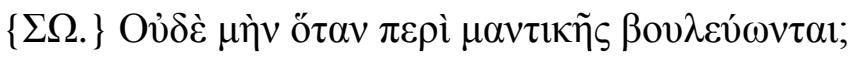

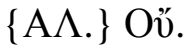

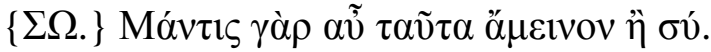

5

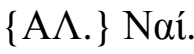

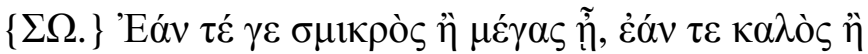

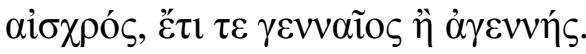

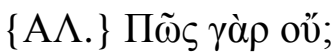

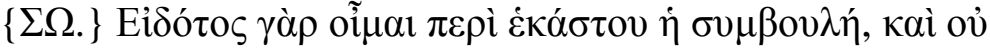

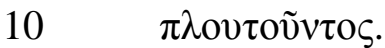

$\{\mathrm{A} \Lambda.\} \Pi \tilde{\omega} \varsigma \gamma \grave{\alpha} \rho$ ớ;

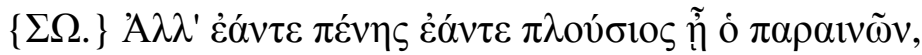

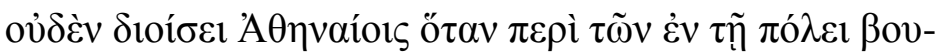

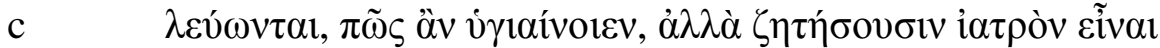

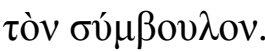

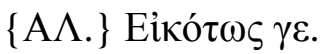

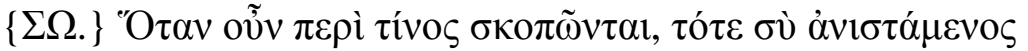

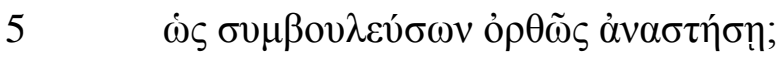

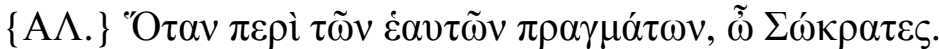


[ALC.] Não, por Zeus.

[SÓC.] Então, quando deliberarem sobre os sons da lira?

[ALC.] De maneira alguma.

[SÓC.] Sem dúvida, tampouco sobre estratagemas de luta eles costumam deliberar em assembleia.

[ALC.] Tampouco, certamente.

[SÓC.] Então, quando eles deliberarem sobre o quê? Pois suponho que também não seja quando deliberarem sobre a construção de edifícios.

[ALC.] Também não.

[SÓC.] Pois sobre isso um arquiteto será melhor conselheiro do que você.

[ALC.] Sim.

[SÓC.] Nem mesmo quando deliberarem sobre a arte divinatória, não é?

[ALC.] Não.

[SÓC.] Pois um adivinho será melhor do que você nesse assunto.

[ALC.] Sim.

[SÓC.] Seja ele baixo ou alto, belo ou feio, ou mesmo nobre ou plebeu.

[ALC.] E como não?

[SÓC.] Pois penso que o conselho sobre cada matéria compete a quem possui conhecimento, e não a quem possui riqueza.

[ALC.] E como não o seria?

[SÓC.] Mas não fará qualquer diferença aos atenienses, quando deliberarem sobre assuntos que concirnam à saúde de quem vive na cidade, se é pobre ou rico quem aconselha, mas procurarão antes que o conselheiro seja um médico.

[ALC.] E com razão.

[SÓC.] Então, ao investigarem a respeito do quê, você se erguerá com acerto para lhes aconselhar?

[ALC.] Quando investigarem a respeito dos assuntos que lhes são próprios, Sócrates. 


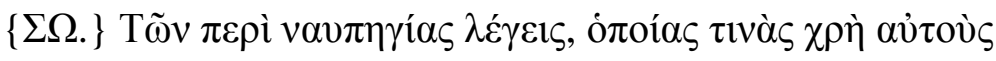

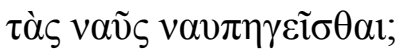

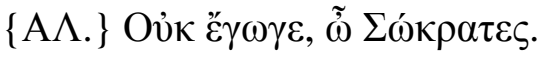

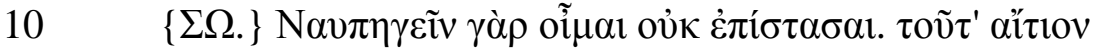

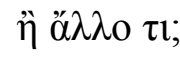

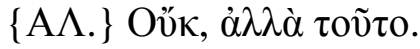

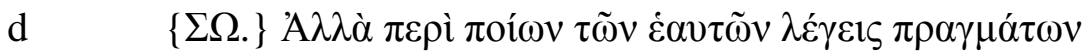

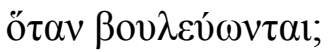

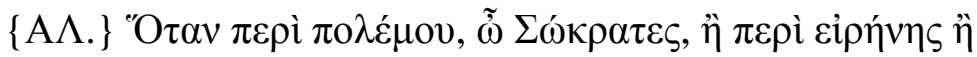

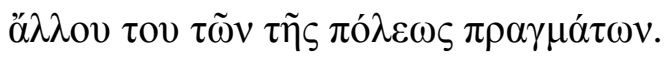

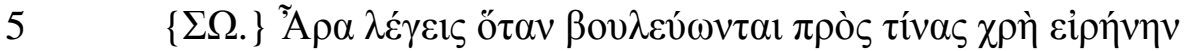

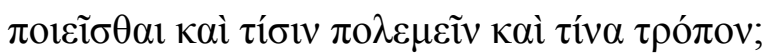

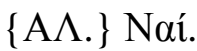

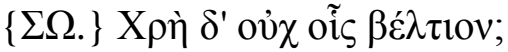

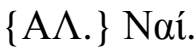

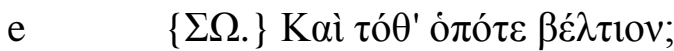

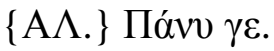

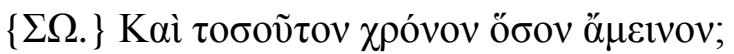

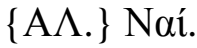

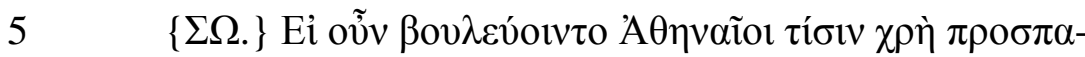

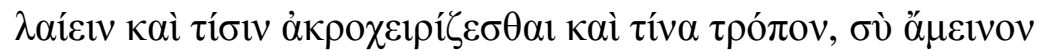

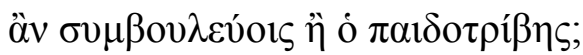

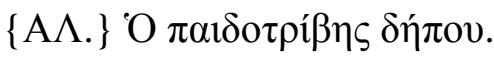

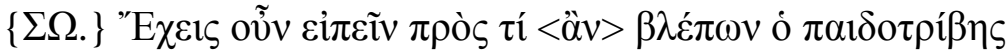

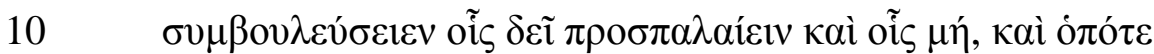

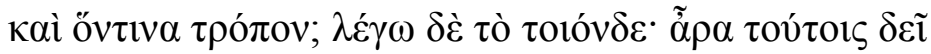

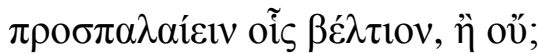

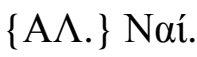

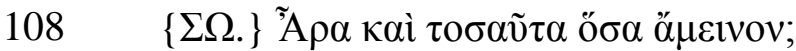


[SÓC.] Você fala das construções de navios, sobre quais tipos de navio é necessário que eles construam?

[ALC.] Não é isso, Sócrates.

[SÓC.] Pois suponho que você não sabe construir navios. É por isso ou por outra razão?

[ALC.] Não, é por isso mesmo.

[SÓC.] Mas, afinal, você está dizendo que se erguerá quando eles d deliberarem sobre quais tipos de assuntos que lhes são próprios?

[ALC.] Quando deliberarem sobre a guerra, Sócrates, ou sobre a paz ou sobre qualquer outro assunto que concirna à cidade.

[SÓC.] Portanto, você está afirmando que é quando eles deliberarem sobre com quem devem firmar a paz e com quem devem travar guerra, e de que maneira?

[ALC.] Sim.

[SÓC.] E não devem fazê-lo com quem é melhor fazê-lo?

[ALC.] Sim.

[SÓC.] E na ocasião em que for melhor?

[ALC.] Certamente.

[SÓC.] E por quanto tempo for melhor?

[ALC.] Sim.

[SÓC.] Então, se os atenienses fossem deliberar sobre com quem devem lutar e com quem devem exercitar o pugilato e de que maneira, seria você que os aconselharia da melhor forma, ou o mestre de luta?

[ALC.] Com certeza, o mestre de luta.

[SÓC.] Pode me dizer, então, o que o mestre de luta teria em vista quando aconselhasse com quem se deve lutar e com quem não se deve, quando e de que modo? Eu me refiro ao seguinte: acaso se deve lutar com quem é melhor fazê-lo, ou não?

[ALC.] Sim.

[SÓC.] Portanto, também por quanto tempo for melhor? 


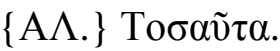

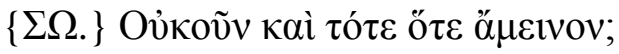

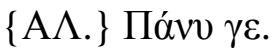

5

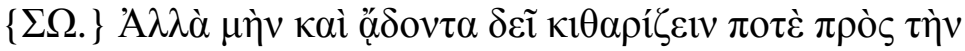

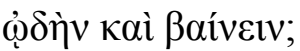

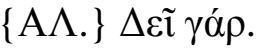

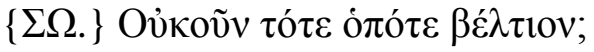

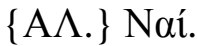

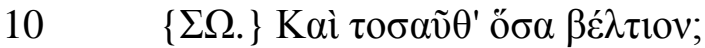

\{А $\Lambda.\} \Phi \eta \mu$.

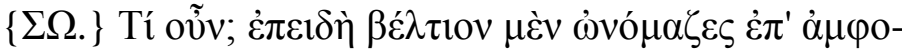

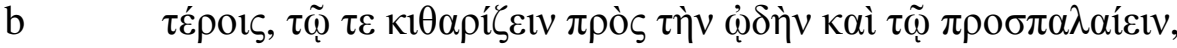

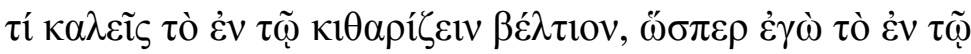

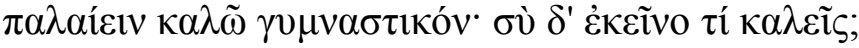

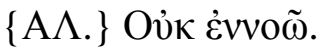

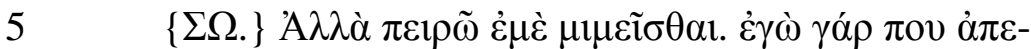

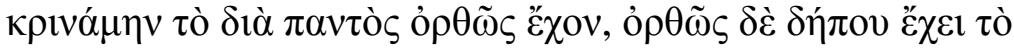

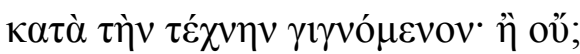

$\{$ A $\Lambda$.$\} Naí.$

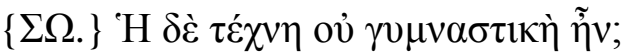

$10 \quad\{\mathrm{~A} \Lambda.\} \Pi \tilde{\omega} \varsigma \delta^{\prime}$ ovँ;

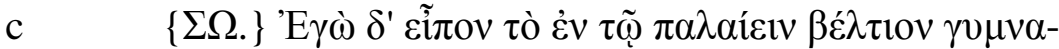

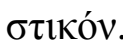

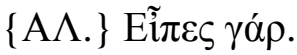

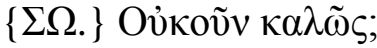

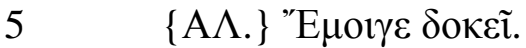

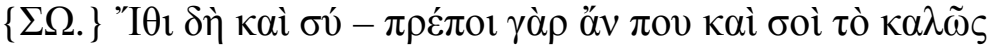

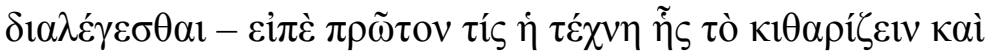

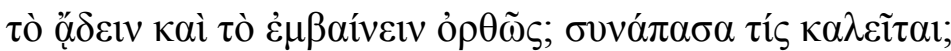


[ALC.] Sim.

[SÓC.] E na ocasião em que for melhor?

[ALC.] Certamente.

[SÓC.] Com efeito, também quando alguém estiver cantando, é preciso tocar a cítara para acompanhar o canto e ritmar os passos, não é?

[ALC.] Sim, é preciso.

[SÓC.] E na ocasião em que for melhor?

[ALC.] Sim.

[SÓC.] E por quanto tempo for melhor?

[ALC.] Concordo.

[SÓC.] E então? Uma vez que você emprega o termo 'melhor' em ambos os casos, em relação a tocar a cítara para acompanhar o canto e em relação a b lutar, o que você chama de 'melhor' no que se refere a tocar a cítara, assim como eu chamo de 'atlético' o que se refere à luta? Como você o denomina?

[ALC.] Não entendo.

[SÓC.] Então tente me imitar! Pois eu respondi, suponho eu, o que é correto em todos os casos, e é correto o que se realiza de acordo com a arte; ou não?

[ALC.] Sim.

[SÓC.] E a arte não era a ginástica?

[ALC.] E como não?

[SÓC.] E eu disse que o melhor na luta era "atlético".

[ALC.] Sim, você disse.

[SÓC.] E não foi dito corretamente?

[ALC.] Parece-me que sim.

[SÓC.] Então agora é a sua vez - pois suponho que também lhe conviria dialogar corretamente - diga-me primeiro qual é a arte relativa a tocar a cítara, cantar e ritmar os passos corretamente! Como ela é denominada como um todo? 


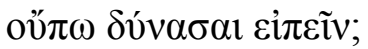

$10\{$ A $\Lambda$.$\} O \delta \tilde{\eta} \tau \alpha$.

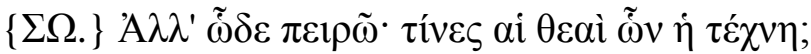

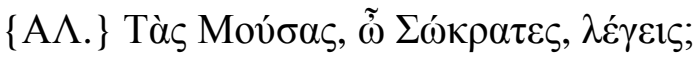

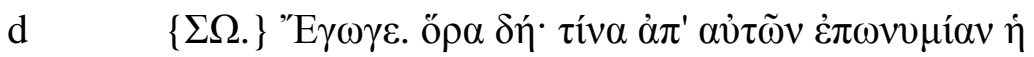
$\tau \varepsilon ́ \chi v \eta \ddot{\varepsilon} \chi \varepsilon 1$

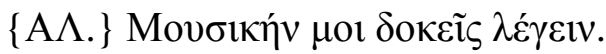

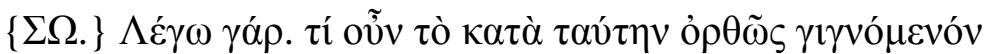

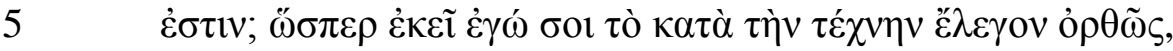

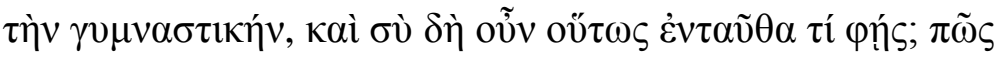

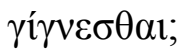

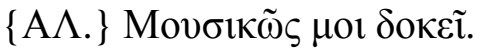

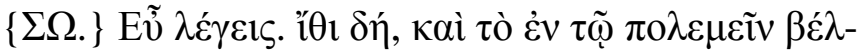

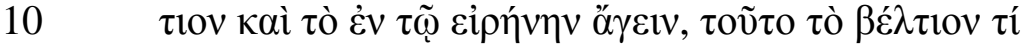

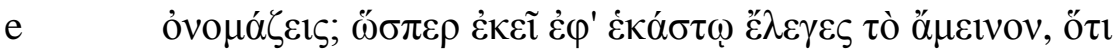

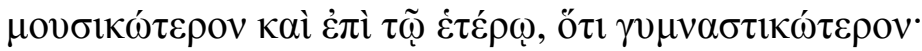

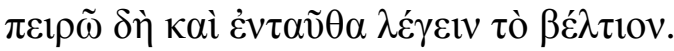

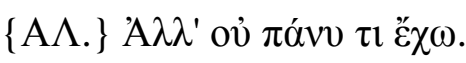

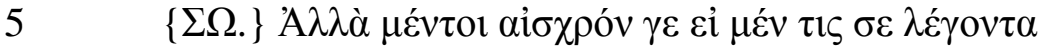

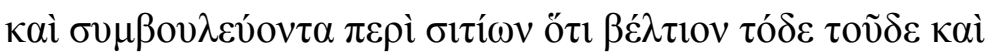

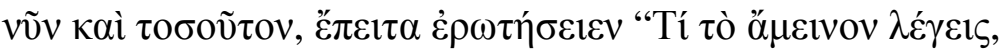

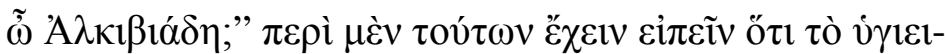

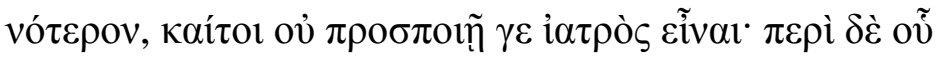

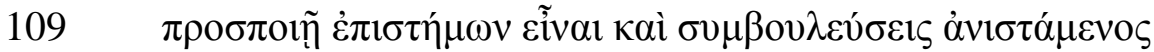

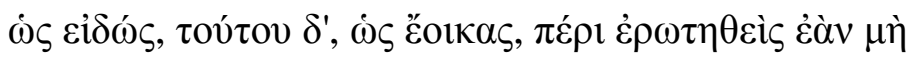

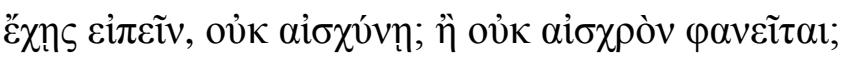

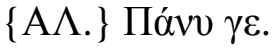

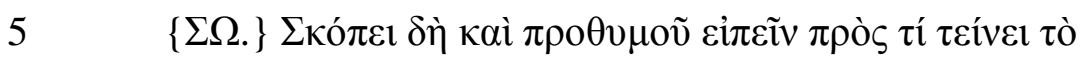

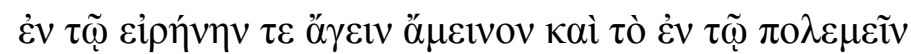


Ainda não é capaz de responder?

[ALC.] Ainda não.

[SÓC.] Então tente assim: quais são as deusas às quais pertence a arte?

[ALC.] Você se refere às Musas, Sócrates?

[SÓC.] De fato. Observe então! Qual é o nome da arte denominada a partir d delas?

[ALC.] Parece-me que você se refere à música.

[SÓC.] Sim, me refiro a isso. Então, o que é aquilo que se realiza corretamente de acordo com essa arte? Assim como eu me referia, naquele caso, ao que se realiza corretamente de acordo com aquela arte, a ginástica, o que então você tem a dizer sobre esse caso? Como se realiza?

[ALC.] Parece-me que "musicalmente".

[SÓC.] Bem dito. Continue então: no que se refere ao que é melhor na guerra e na condução da paz, o que você denomina de 'melhor'? Assim como se referia ao melhor em cada um daqueles casos, ao que é mais musical, de um lado, e ao que é mais atlético, de outro, tente também dizer, nesse caso, o que é melhor!

[ALC.] Mas não tenho muito a dizer.

[SÓC.] Mas se alguém, enquanto você argumentasse e aconselhasse sobre provisões - que esta é melhor do que aquela neste momento e nesta quantidade - viesse a lhe perguntar "o que você quer dizer com 'melhor', Alcibíades?", seria certamente vergonhoso que, a respeito desse assunto, você pudesse lhe responder que é o mais saudável, embora não professasse ser um médico. Porém, a respeito daquilo que você professa conhecer e pretende se levantar para dar conselhos como se conhecesse, a respeito desse assunto, como parece, você não se envergonhará se não souber responder, como parece, às questões que lhe são dirigidas? Ou não lhe parecerá vergonhoso?

[ALC.] Com certeza.

[SÓC.] Examine então e esteja pronto para responder: a que tende o "melhor" tanto em estabelecer a paz quanto em fazer guerra 
oĩ $\delta \varepsilon \tilde{i} ;$

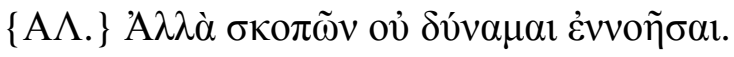

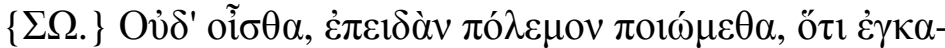

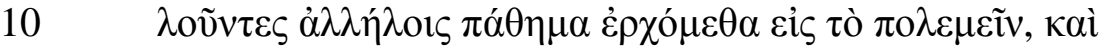

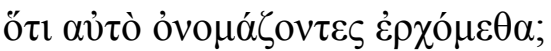

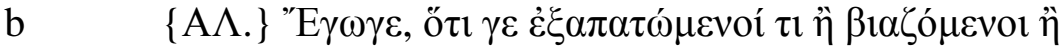

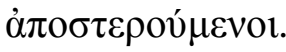

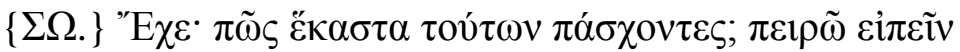

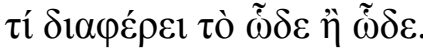

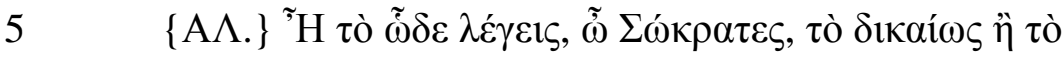

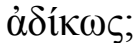

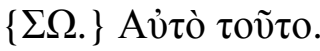

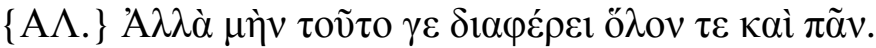

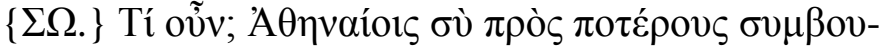

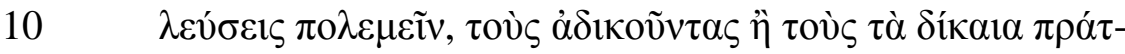
$\tau \mathrm{ov \tau \alpha \varsigma ;}$

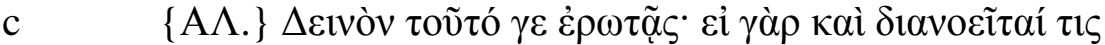

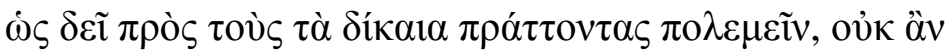

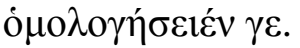

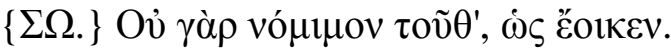

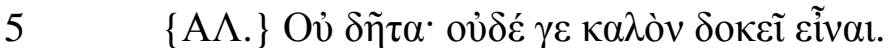

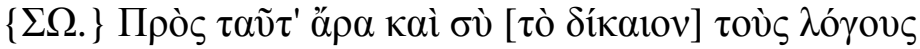

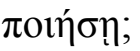

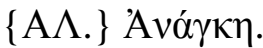

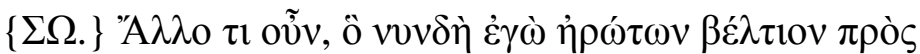

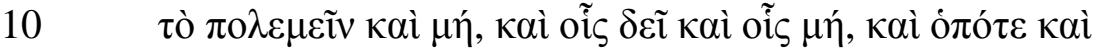

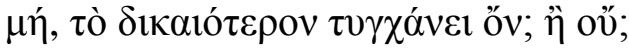

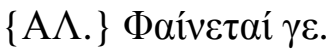

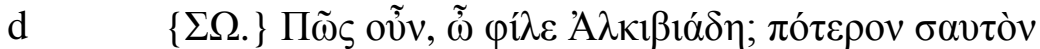


com quem se deve?

[ALC.] Mas mesmo examinando não consigo compreender.

[SÓC.] Mas não sabe que, sempre que entramos em guerra, partimos para a batalha acusando uns aos outros de certas ofensas e nominando-as?

[ALC.] Sei sim; alegamos que estamos sendo ultrajados de algum modo, ou b que somos vítimas da violência, ou que estamos sendo espoliados.

[SÓC.] Espere! Como sofremos cada uma dessas coisas? Tente responder o que distingue uma maneira da outra!

[ALC.] É disto que você fala, Sócrates: de maneira justa ou de maneira injusta?

[SÓC.] Exatamente.

[ALC.] Mas, na verdade, isso faz toda a diferença.

[SÓC.] E então? Você irá aconselhar os atenienses a declarar guerra contra aqueles que cometem injustiças ou contra os que agem de modo justo?

[ALC.] É terrível a sua pergunta. Pois mesmo se alguém considerasse que se deve guerrear contra os que agem de modo justo, ele não poderia admitilo.

[SÓC.] Pois isso não é legítimo, ao que parece.

[ALC.] Não mesmo. E nem parece ser belo.

[SÓC.] Tendo em vista essas coisas, portanto, você fará seus discursos?

[ALC.] Necessariamente.

[SÓC.] Não é verdade, então, que o 'melhor' sobre o qual há pouco eu o indagava - sobre fazer guerra ou não, com quem se deve fazê-lo e com quem não se deve, em que ocasião sim e em que ocasião não - acontece de ser o que é mais justo? Ou não?

[ALC.] É claro que sim.

[SÓC.] E agora, meu caro Alcibíades? É você 


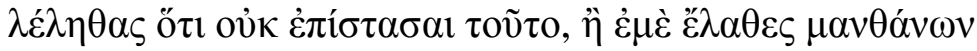

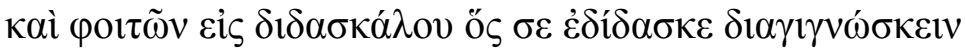

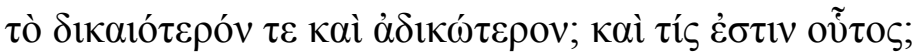

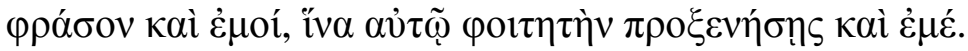

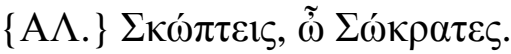

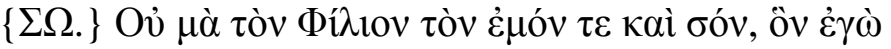

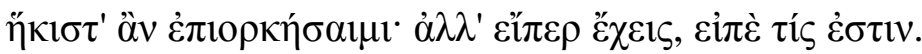

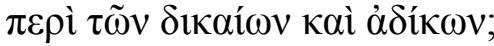

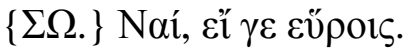

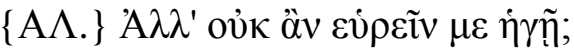

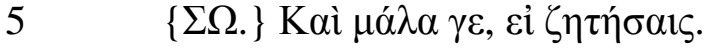

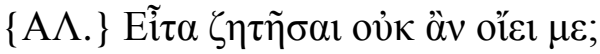

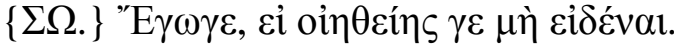

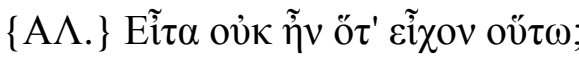

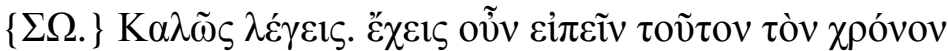

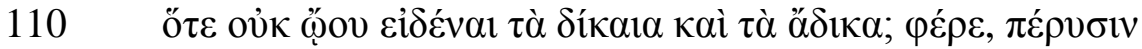

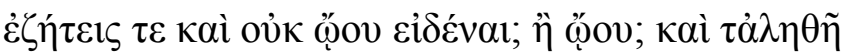

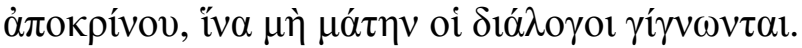

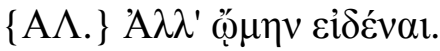

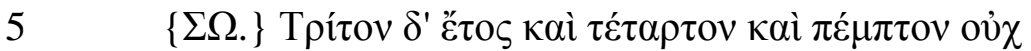
oũ $\tau \omega \varsigma ;$

$\{\mathrm{A} \Lambda.\}{ }^{\prime} \mathrm{E} \gamma \omega \gamma \varepsilon$.

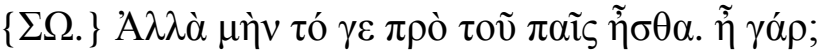

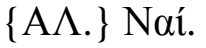

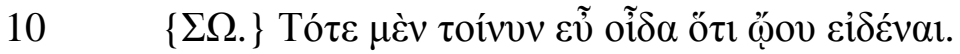

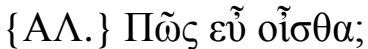

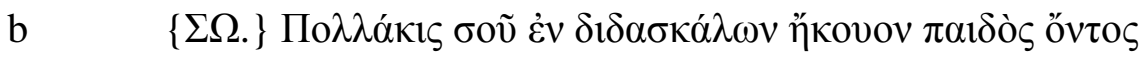

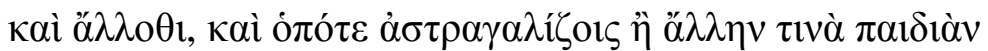


que não percebe que não possui conhecimento a respeito disso, ou fui eu que não me dei conta do seu aprendizado com um professor que lhe ensinou a discernir bem o mais justo do mais injusto? E quem é ele? Diga-me quem é para que você me recomende a ele como pupilo.

[ALC.] Você está me zombando, Sócrates.

[SóC.] Não, pelo deus da Amizade minha e sua, contra o qual eu dificilmente perjuraria! Se você puder, diga-me quem é ele!

[ALC.] Mas o que direi se não posso dizê-lo? Você não julga que eu e poderia saber a respeito do justo e do injusto de outra maneira?

[SÓC.] Sim, se você o descobrisse.

[ALC.] Mas não considera que eu poderia descobri-lo?

[SóC.] Claro que sim, se o investigasse.

[ALC.] E não pensa que eu o investigaria?

[SÓC.] Sim, se julgasse não conhecê-lo.

[ALC.] E não houve um tempo em que eu pensava assim?

[SÓC.] Belas palavras as suas. Pode dizer, então, quando foi que você não julgava conhecer o que é justo e o que é injusto? Vamos lá! Ano passado investigava tal matéria e julgava não conhecê-la? Ou julgava conhecê-la? E responda a verdade, para que nosso diálogo não seja em vão!

[ALC.] Mas eu julgava conhecê-la.

[SÓC.] E não era assim dois, três, quatro anos atrás?

[ALC.] De fato.

[SÓC.] Com efeito, antes disso você era um menino. Não é mesmo?

[ALC.] Sim.

[SÓC.] E bem sei que naquele tempo você já julgava conhecê-la.

[ALC.] Como sabe disso tão bem?

[SÓC.] Muitas vezes eu o ouvi, quando ainda era um menino, nas aulas e b em outros lugares, e quando jogava astrágalo ou algum outro jogo, 


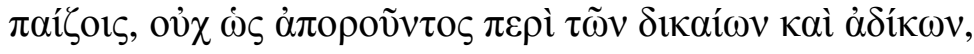

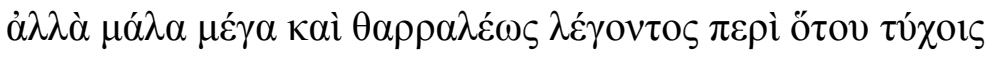

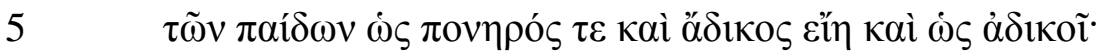

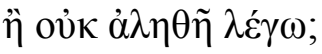

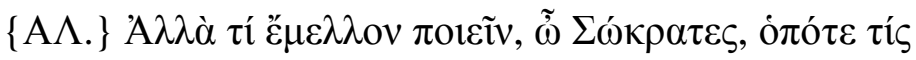
$\mu \varepsilon \dot{\alpha} \delta 1 \kappa o \tilde{i}$

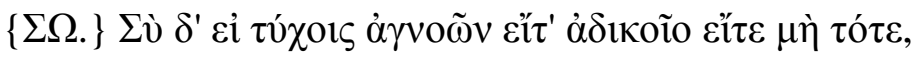

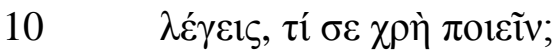

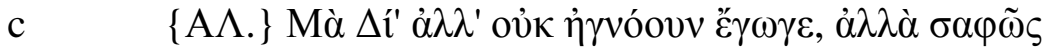

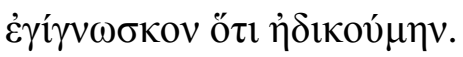

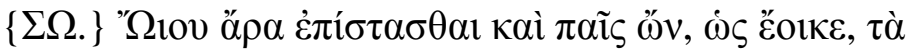

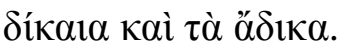

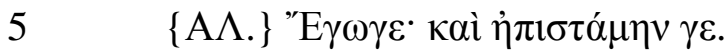

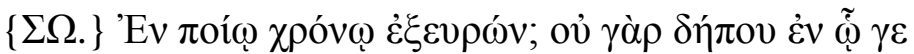

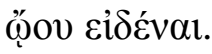

$\{\mathrm{A} \Lambda$.$\} O \delta \tilde{\eta} \tau \alpha$.

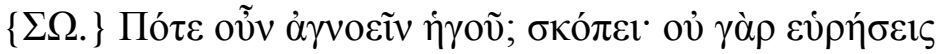

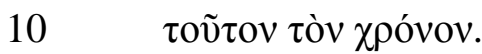

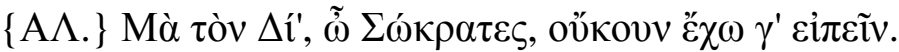

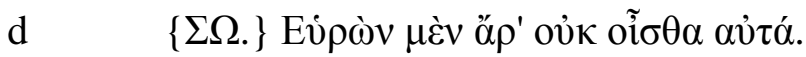

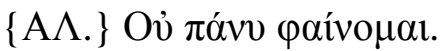

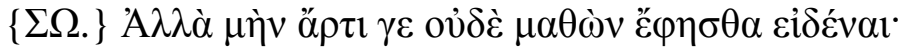

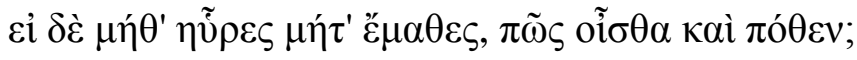

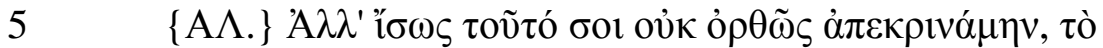

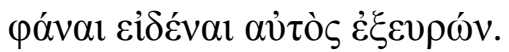

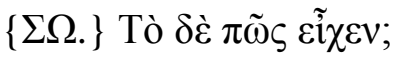

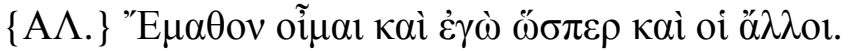

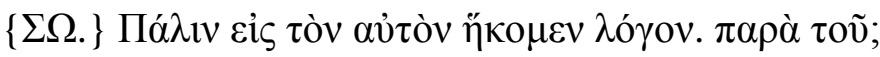

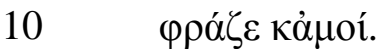


não hesitando sobre o que era justo e injusto, mas, muito altivo e confiante, dizendo para um ou outro menino com quem jogava que ele era trapaceiro e injusto e que cometia injustiças. É verdade ou não o que estou dizendo?

[ALC.] Mas o que eu podia fazer, Sócrates, quando alguém me injustiçava?

[SÓC.] Se por acaso ignorasse naquela ocasião se era ou não injustiçado, diga-me você: o que devia fazer?

[ALC.] Por Zeus, eu não o ignorava; pelo contrário, eu tinha absoluta certeza de que estava sendo injustiçado.

[SÓC.] Portanto, julgava conhecer, mesmo que ainda menino, ao que parece, o que é justo e o que é injusto.

[ALC.] De fato. E conhecia mesmo.

[SÓC.] Em que época você o descobriu? Pois certamente não foi quando julgava conhecê-lo.

[ALC.] É certo que não.

[SÓC.] Em que época, então, considerava ignorá-lo? Examine: pois não a encontrará.

[ALC.] Por Zeus, Sócrates, eu realmente não consigo responder.

[SÓC.] Portanto, você não conhece essa matéria por ter descoberto.

[ALC.] De fato, não pareço tê-la descoberto.

[SÓC.] Mas, na verdade, há pouco você dizia que também não foi por ter aprendido que você a conhecia. Se você nem a descobriu e nem a aprendeu, como é que você a conhece e de onde?

[ALC.] Mas talvez eu não tenha respondido corretamente, ao dizer que eu a conhecia por ter descoberto por mim mesmo.

[SÓC.] E como isso ocorreu?

[ALC.] Penso que eu aprendi da mesma maneira que os demais.

[SÓC.] Voltamos de novo à mesma questão! Com quem? Diga-me! 


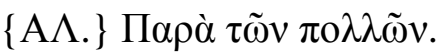

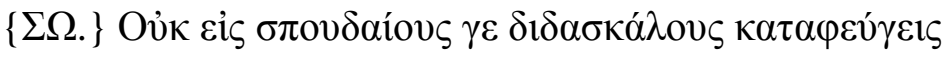

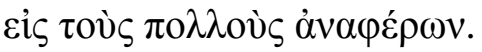

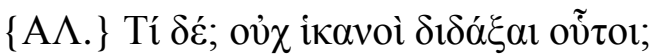

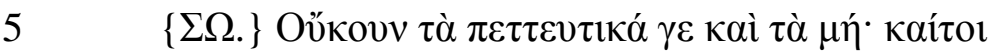

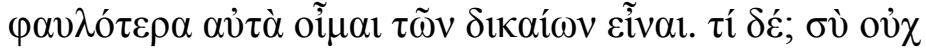

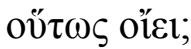

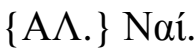

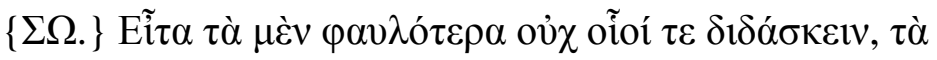

$10 \quad \delta \dot{\varepsilon} \sigma \pi 0 v \delta \alpha 10 ́ \tau \varepsilon \rho \alpha$

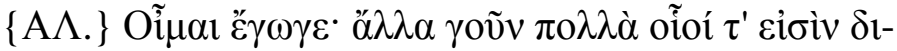

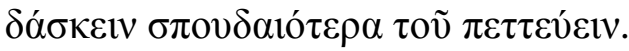

$\{\Sigma \Omega$.$\} Пог̃ \alpha \alpha \tilde{v} \tau \alpha ;$

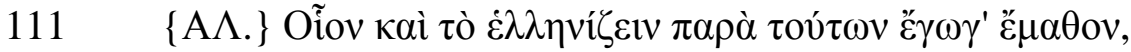

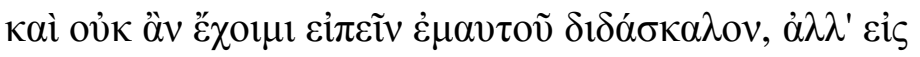

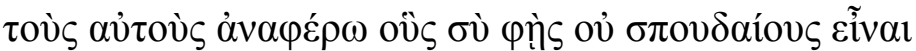
$\delta 1 \delta \alpha \sigma \kappa \alpha ́ \lambda o v \varsigma$.

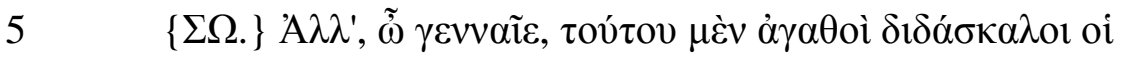

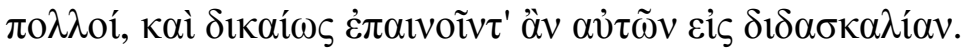
$\{\mathrm{A} \Lambda$.$\} Tí \delta \eta \dot{;}$

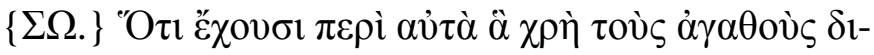

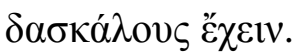

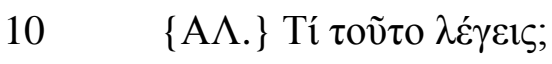

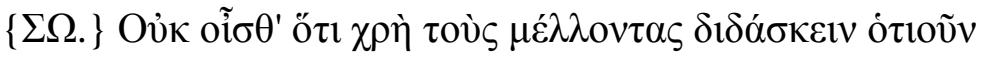

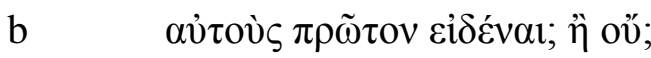

$\{\mathrm{A} \Lambda.\} \Pi \tilde{\omega} \varsigma \gamma \grave{\alpha} \rho$ oú;

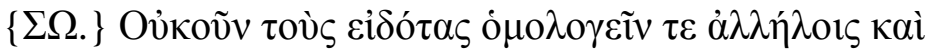

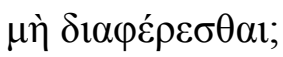

$5 \quad\{$ A $\Lambda$.$\} Naí.$ 
[ALC.] Com a multidão.

[SÓC.] Você não recorre a professores muito estimáveis ao apelar para a multidão.

[ALC.] Por quê? Não são competentes para ensinar?

[SÓC.] Nem mesmo no que se refere ou não aos movimentos do jogo de gamão. E mais, penso que isso é insignificante em comparação a questões de justiça. E então? Você não pensa assim?

[ALC.] Sim.

[SÓC.] Então, se a respeito de questões mais frívolas são incapazes de ensinar, o que acontece quanto às mais importantes?

[ALC.] Penso o seguinte: são capazes, sim, de ensinar muitas coisas mais importantes do que jogar gamão.

[Sóc.] Quais?

[ALC.] Eu mesmo, por exemplo, aprendi a falar grego com eles, e não saberia dizer quem foi meu professor; recorro antes a eles, todavia, os quais você diz não serem professores estimáveis.

[SÓC.] Mas, nobre homem, a multidão dos homens são estimáveis professores dessa matéria, e com justiça eles seriam louvados pelo ensinamento dela.

[ALC.] E por quê?

[SÓC.] Porque ela possui sobre essa matéria o que os bons professores precisam deter.

[ALC.] O que você quer dizer com isso?

[SÓC.] Você não sabe que os futuros professores do que quer que seja devem, eles próprios, primeiro possuir conhecimento? Ou não?

[ALC.] Como não?

[SÓC.] Então, aqueles que possuem conhecimento não devem concordar uns com os outros e não divergir entre si?

[ALC.] Sim. 


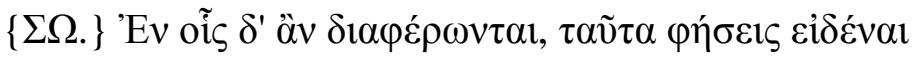

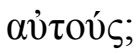

$\{\mathrm{A} \Lambda$.$\} O \delta \tilde{\eta} \tau \alpha$.

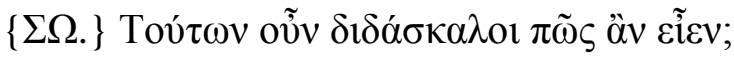

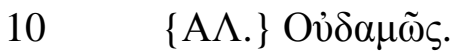

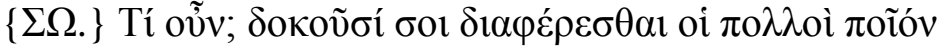

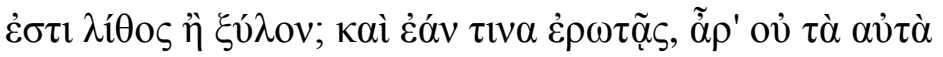

c

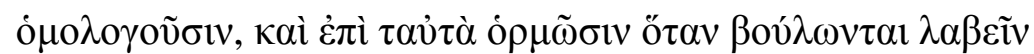

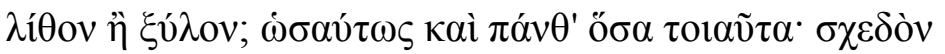

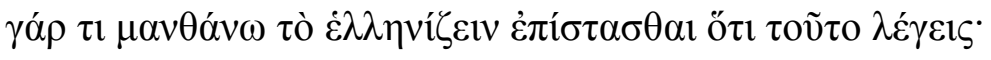
ì oú;

5

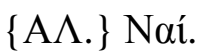

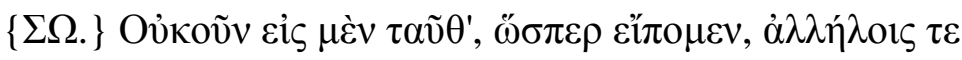

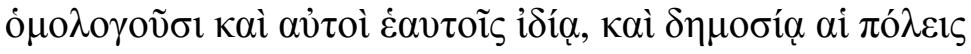

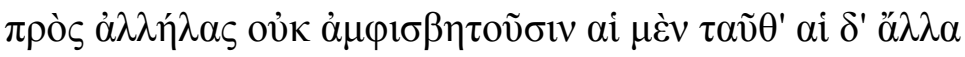

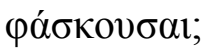

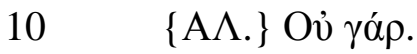

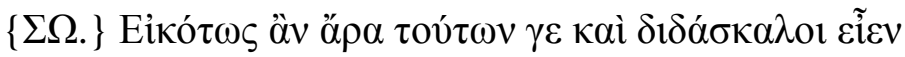

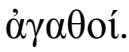

$\mathrm{d}$

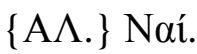

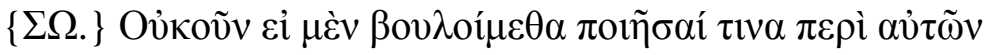

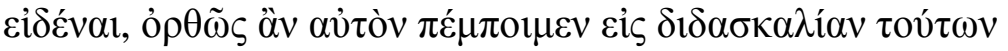
$\tau \tilde{\omega} v \pi \mathrm{\sigma} \lambda \lambda \tilde{\omega} v$

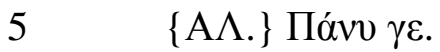

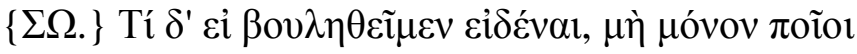

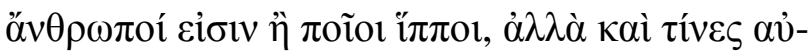

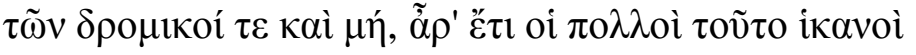
$\delta 1 \delta \alpha ́ \xi \alpha 1 ;$

$10 \quad\{\mathrm{~A} \Lambda$.$\} Ov̉ \delta \tilde{\eta} \tau \alpha$. 
[SÓC.] E naquelas coisas em que divergirem entre si, você ainda há de dizer que eles as conhecem?

[ALC.] É claro que não.

[SÓC.] E como, então, eles seriam professores dessas matérias?

[ALC.] De maneira alguma seriam.

[SÓC.] E então? A multidão dos homens lhe parece discordar a respeito do que é a pedra ou a madeira? E se você perguntar a qualquer um, por acaso não darão a mesma resposta e não buscarão a mesma coisa quando quiserem pegar uma pedra ou uma madeira? O mesmo sucede a qualquer assunto desse tipo. É mais ou menos isso o que eu entendo o que você quis dizer com 'saber falar grego'. Ou não?

[ALC.] Sim.

[SÓC.] Então, em relação a essas coisas, como dissemos, eles concordam uns com os outros e eles próprios consigo mesmos em particular, e no âmbito público, as cidades não divergem umas das outras, uma parte afirmando uma coisa, e outra parte afirmando outra, não é?

[ALC.] Certamente.

[SÓC.] Portanto, seriam plausivelmente bons professores dessas matérias.

[ALC.] Sim.

[SÓC.] Então, se quiséssemos proporcionar a alguém o conhecimento delas, com razão o enviaríamos para o ensinamento que a multidão tem a oferecer?

[ALC.] Certamente.

[SÓC.] Mas e se quiséssemos conhecer não somente o que são os homens ou os cavalos, mas também quais deles são velozes e quais não o são? Acaso a maioria dos homens ainda seria capaz de nos ensinar isso?

[ALC.] É certo que não. 


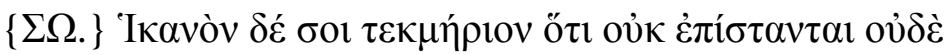

$\mathrm{e}$

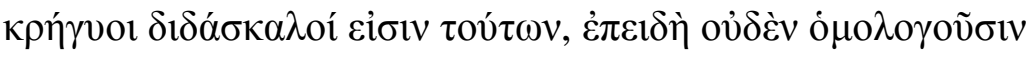

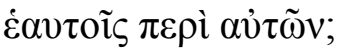

$\{\mathrm{A} \Lambda.\}{ }^{\prime} \mathrm{E \mu or \gamma \varepsilon .}$

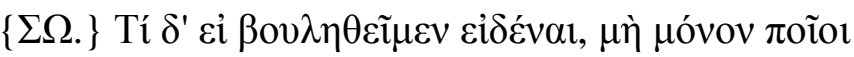

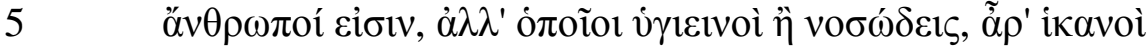
àv $\dot{\eta} \mu \mathrm{i} v \tilde{\eta} \sigma \alpha v \delta 1 \delta \alpha ́ \sigma \kappa \alpha \lambda \mathrm{ol}$ oi $\pi \mathrm{o} \lambda \lambda$ oí;

$\{\mathrm{A} \Lambda$.$\} Ov̉ \delta \tilde{\eta} \tau \alpha$.

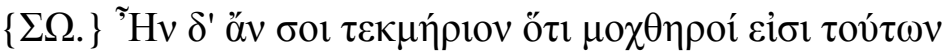

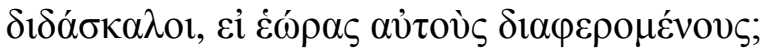

$10 \quad\{\mathrm{~A} \Lambda.\}{ }^{\prime} \mathrm{E} \mu \mathrm{ol \gamma \varepsilon}$.

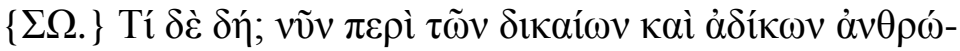

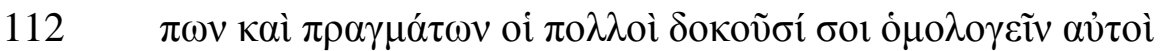

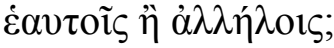

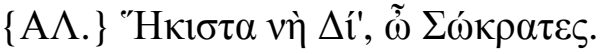

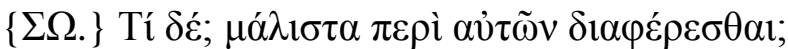

5

$\{\mathrm{A} \Lambda.\} \Pi о \lambda v ́ \gamma \varepsilon$.

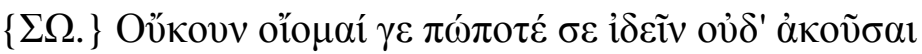

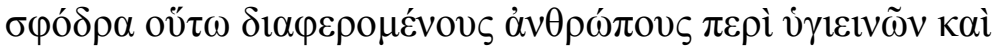
$\mu \eta ́$, $\{\mathrm{A} \Lambda$.$\} Ov̉ \delta \tilde{\eta} \tau \alpha$.

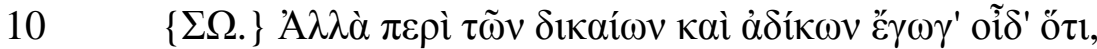

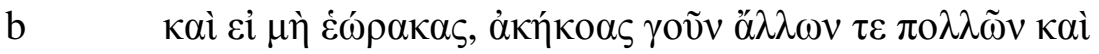

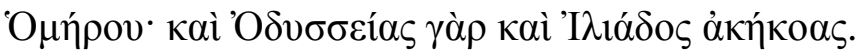

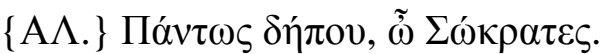

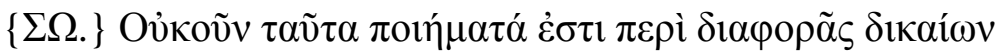

$5 \quad \tau \varepsilon \kappa \alpha \grave{\alpha} \alpha \dot{\delta} \hat{\kappa} \omega \omega$

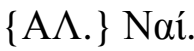

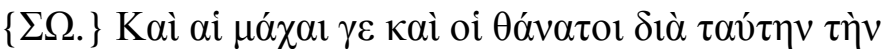


[SÓC.] Mas lhe é evidência suficiente de que eles não possuem conhecimento nem são bons professores disso, visto que não concordam e entre si sobre esses assuntos?

[ALC.] É sim.

[SÓC.] E se quiséssemos conhecer não somente o que são os homens, mas quais são saudáveis ou enfermos, porventura a multidão dos homens seria para nós um professor competente?

[ALC.] Não, decerto.

[SÓC.] E lhe seria evidência suficiente de que eles são maus professores, se os visse divergindo, não seria?

[ALC.] Sim.

[SÓC.] E então? Agora, a respeito dos homens justos e injustos e de suas respectivas ações, parece-lhe que a multidão dos homens concorda consigo própria ou entre si?

[ALC.] Dificilmente, por Zeus, Sócrates.

[SÓC.] E então? Não divergem, sobretudo, nessas questões?

[ALC.] E muito!

[SÓC.] E julgo, pois, que você nunca viu ou ouviu os homens divergirem de maneira tão veemente sobre o que é ou não é saudável, a ponto de, em razão disso, lutarem entre si e matarem uns aos outros.

[ALC.] Certamente nunca.

[SóC.] Mas sobre o que é justo e o que é injusto eu sei que, mesmo que não o tenha visto, já ouviu de muitos outros e de Homero coisas do gênero: pois já escutou a Odisseia e a Ilíada.

[ALC.] Sem dúvidas, Sócrates.

[SÓC.] E não tratam esses poemas de divergências sobre o que é justo e o que é injusto?

[ALC.] Sim.

[SÓC.] E as batalhas e as mortes, 


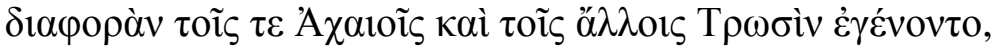

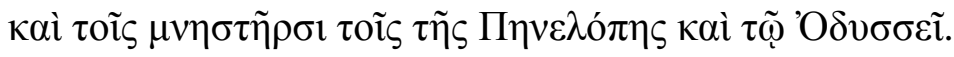
$\{\mathrm{A} \Lambda$.$\} 'A \lambda \eta \theta \tilde{\eta} \lambda \dot{\varepsilon} \gamma \varepsilon 1 \zeta$.

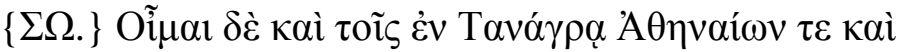

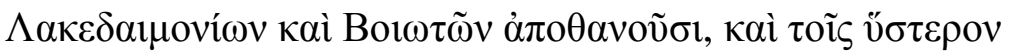

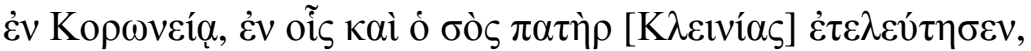

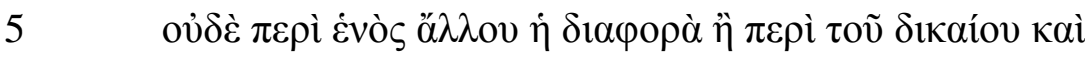

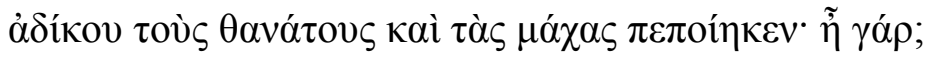
$\{\mathrm{A} \Lambda.\} \mathrm{A} \lambda \eta \theta \tilde{\eta} \lambda \dot{\varepsilon} \gamma \varepsilon 1 \zeta$.

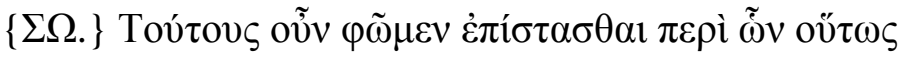

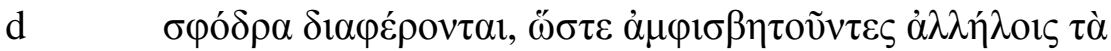

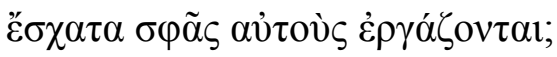

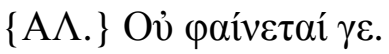

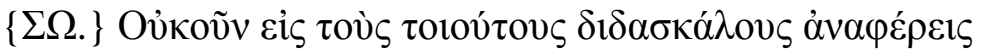

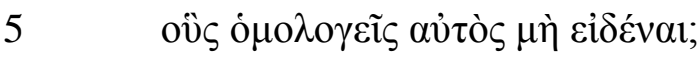

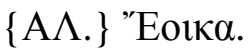

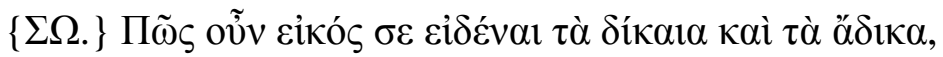

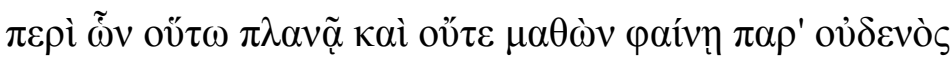

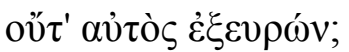

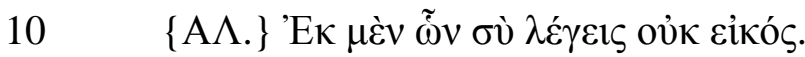

e

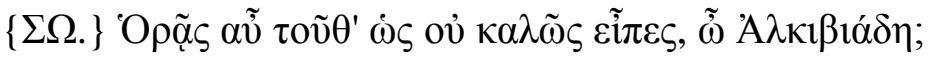

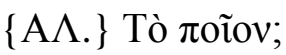

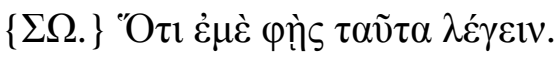

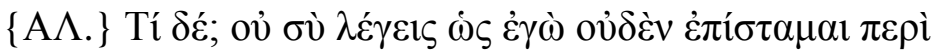

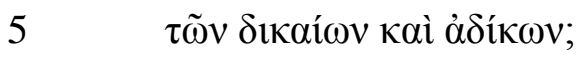

$\{\Sigma \Omega$.$\} Ov̉ \mu \varepsilon ́ v \tau o 1$.

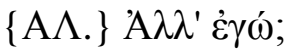

$\{\Sigma \Omega$.$\} Naí.$

$\{\mathrm{A} \Lambda.\} \Pi \tilde{\omega} \varsigma \delta \eta$ 
tanto entre os aqueus e os troianos, quanto entre Odisseu e os pretendentes de Penélope, ocorreram devido a essa divergência.

[ALC.] É verdade o que você diz.

[SÓC.] Penso que também no caso dos atenienses, dos lacedemônios e dos beócios que perderam suas vidas em Tânagra, e posteriormente em Coroneia, entre os quais pereceu o seu pai Clínias, não foi nenhuma outra coisa senão a divergência sobre o que é justo e o que é injusto que causou as mortes e as batalhas. Ou não?

[ALC.] É verdade.

[SÓC.] Então, é certo dizermos que eles possuíam o conhecimento daquilo sobre o que tão veementemente divergiam, a ponto de, uma vez em d discórdia, cometerem os atos mais extremos contra eles próprios?

[ALC.] É claro que não.

[SÓC.] Assim, é a tais professores que você recorre, os quais, como você próprio concorda, não possuem conhecimento?

[ALC.] É o que parece.

[SÓC.] Como é razoável, então, que você conheça o que é justo e o que é injusto, a respeito do que se mostra tão vacilante, sem ter aprendido junto a ninguém nem ter descoberto por si mesmo?

[ALC.] De acordo com o que você diz, não é razoável.

[SÓC.] Você está vendo, Alcibíades, que mais uma vez não deu uma boa e resposta?

[ALC.] Por quê?

[SÓC.] Porque você diz que sou eu quem está dizendo isso.

[ALC.] E daí? Não é você que está dizendo que eu não conheço nada sobre o que é justo e o que é injusto?

[SÓC.] De modo algum.

[ALC.] Mas sou eu?

[SÓC.] Sim.

[ALC.] Como? 


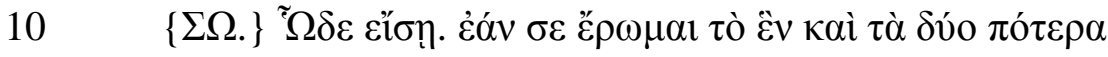

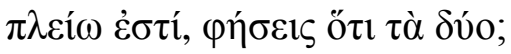

$\{\mathrm{A} \Lambda.\}{ }^{\prime} \mathrm{E} \gamma \omega \gamma \varepsilon$.

$\{\Sigma \Omega$.$\} Пó \omega \omega$

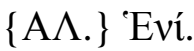

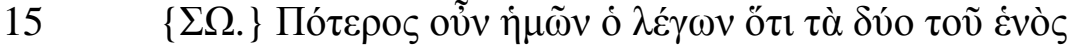
$\dot{\varepsilon} v i ̀ \pi \lambda \varepsilon i ́ \omega$

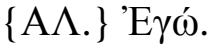

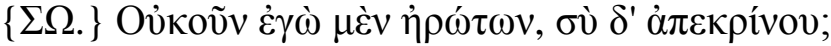

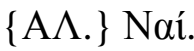

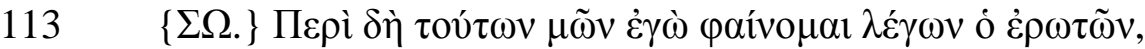

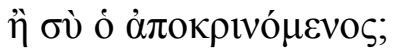

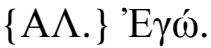

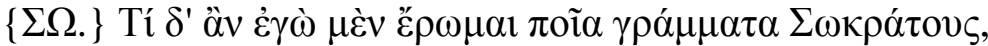

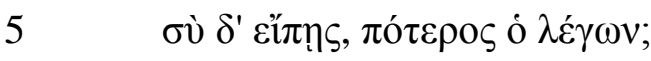

$\{\mathrm{A} \Lambda\} '. E \gamma \omega ́$.

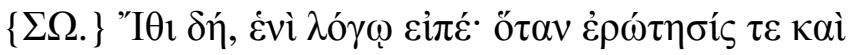

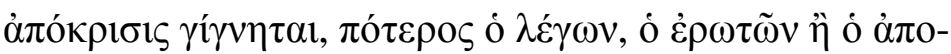

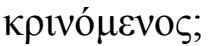

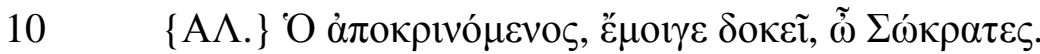

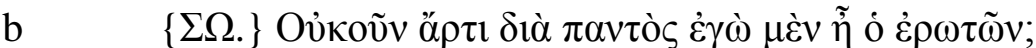

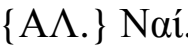

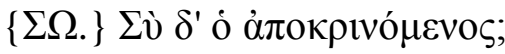

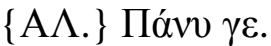

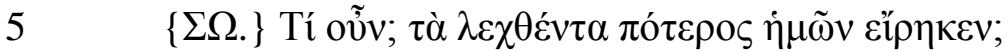

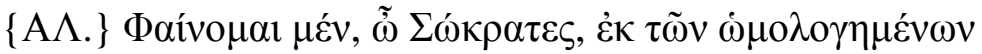

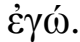

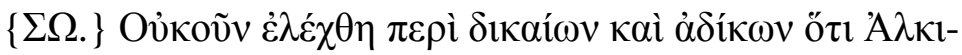

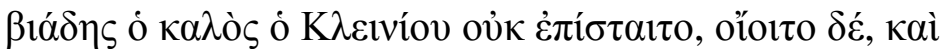


[SÓC.] Compreenderá do seguinte modo: se eu lhe perguntar qual é maior, um ou dois, você responderá que dois é maior?

[ALC.] De fato.

[SÓC.] Quanto maior?

[ALC.] Por um.

[SÓC.] Então, quem de nós respondeu que dois é maior que um por um?

[ALC.] Fui eu.

[SÓC.] Não era eu que perguntava, enquanto você respondia?

[ALC.] Sim.

[SÓC.] A respeito disso, quem parece dizer sou eu, o inquiridor, ou você, o inquirido?

[ALC.] Sou eu.

[SÓC.] E se eu lhe pedir para soletrar 'Sócrates' e você o soletrar, quem de nós estará dizendo?

[ALC.] Eu.

[SÓC.] Continue e responda numa só palavra! Quando houver uma pergunta e uma resposta, quem é que diz: o inquiridor ou o inquirido?

[ALC.] Parece-me que o inquirido, Sócrates.

[SÓC.] E não era eu o inquiridor durante toda a discussão de agora há b pouco?

[ALC.] Sim.

[SÓC.] E você, o inquirido?

[ALC.] Certamente.

[SÓC.] E então? Quem de nós disse o que foi dito?

[ALC.] Pelo que foi assentido, Sócrates, é claro que fui eu.

[SÓC.] Sendo assim, foi dito que Alcibíades, o belo filho de Clínias, não conhece o que é justo e o que é injusto, apesar de presumir sabê-lo, e 


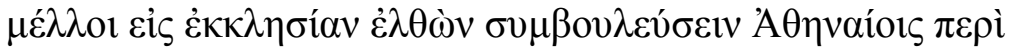

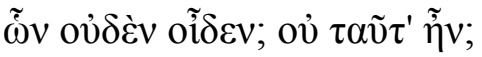

c

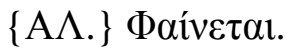

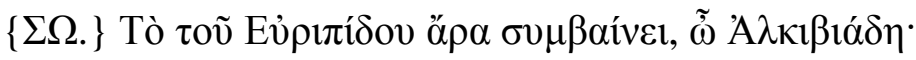

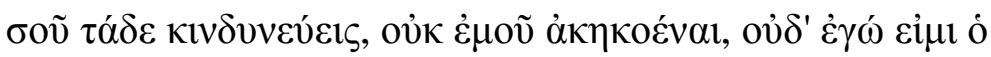

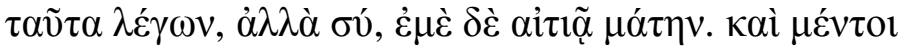

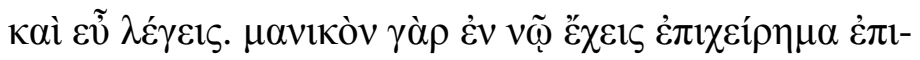

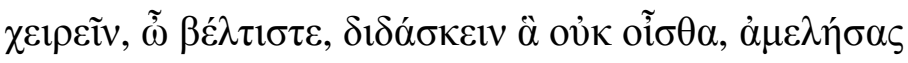
$\mu \alpha v \theta \alpha ́ v \varepsilon ı v$.

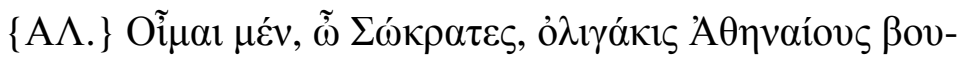

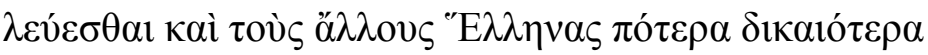

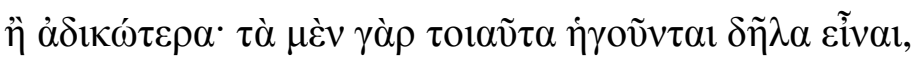

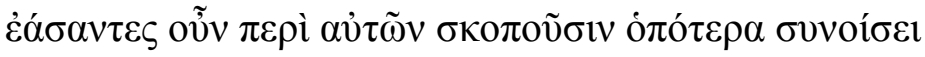

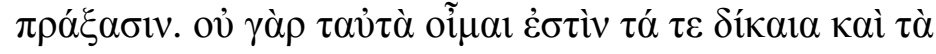

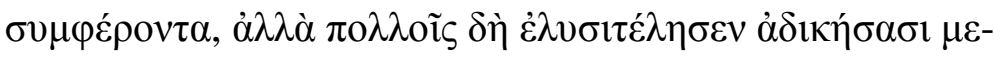

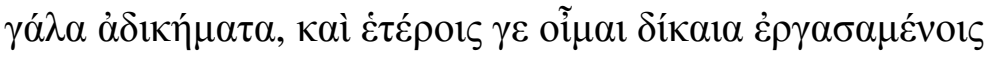

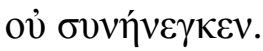

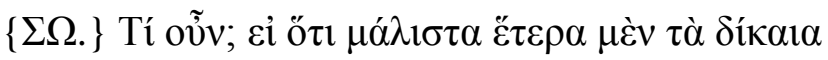

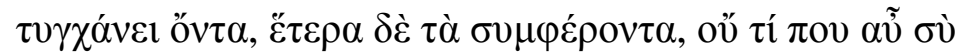

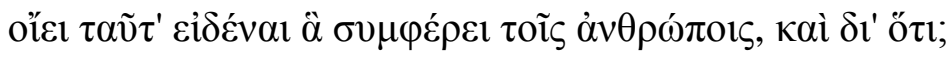

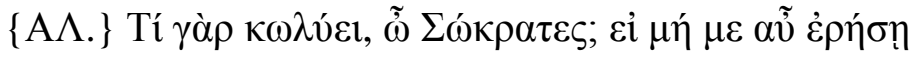

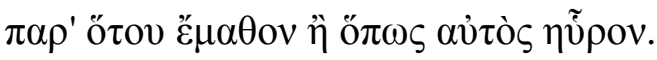

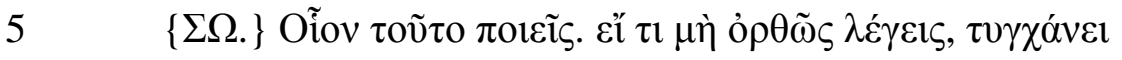

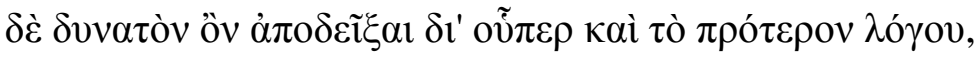

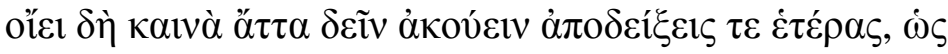

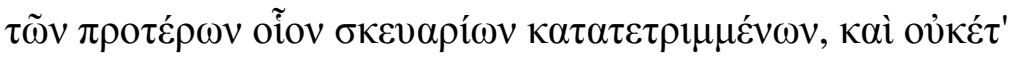

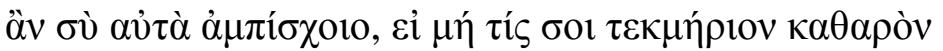

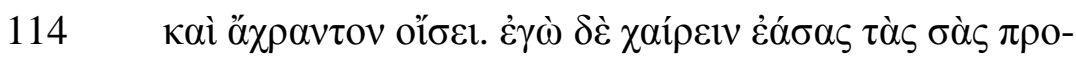

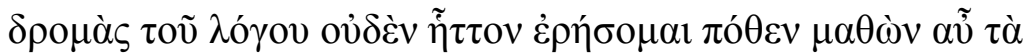


que está prestes a se apresentar na assembleia para aconselhar os atenienses a respeito do que não sabe. Não foi isso?

[ALC.] Claro que sim.

[SÓC.] Portanto, ocorre o que diz Eurípides, ó Alcibíades: "tais coisas você deve ter ouvido de você, e não de mim, tampouco sou eu quem está dizendo, mas você mesmo, e a mim acusa em vão.” Todavia, ao menos isso você fala com acerto. Pois planeja dar um passo insano, excelente homem, o de ensinar aquilo que não sabe, tendo se descuidado de aprendê-lo.

[ALC.] Mas penso, Sócrates, que raramente os atenienses e os demais helenos deliberam sobre o que é mais justo ou o que é mais injusto. Pois consideram tais coisas evidentes, de modo que as deixam de lado e passam a examinar quais ações são vantajosas. Não penso que o que é justo e o que é vantajoso sejam a mesma coisa, mas, de fato, as maiores injustiças beneficiam a muitos infratores, e penso que ações justas não são vantajosas para quem as pratica.

[SÓC.] E então? Se o que é justo e o que é vantajoso ocorrem de ser distintos ao máximo, certamente você não considera, mais uma vez, que possui conhecimento do que é vantajoso para os homens e por qual razão. Ou considera?

[ALC.] O que me impede, Sócrates? A menos que me pergunte de novo com quem aprendi ou de que maneira descobri por mim mesmo.

[SÓC.] Que maneira de agir! Se você diz algo incorreto e o argumento precedente pode demonstrar por que razão, você de fato julga que é preciso ouvir novas demonstrações diferentes, como se as anteriores parecessem roupas já bem gastas, as quais você não mais usaria, a menos que alguém lhe trouxesse uma evidência pura e imaculada. Porém eu, ignorando os seus assaltos ao meu argumento, perguntarei a você novamente de onde aprendeu 


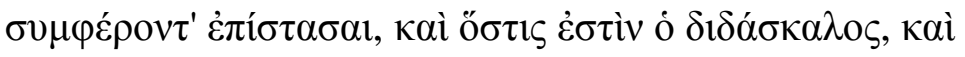

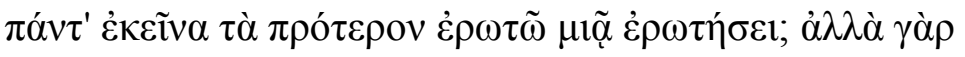

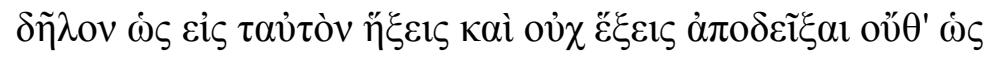

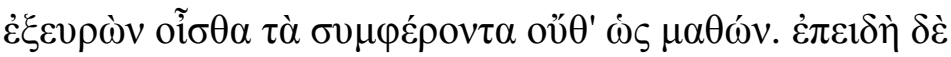

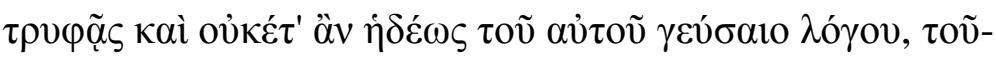

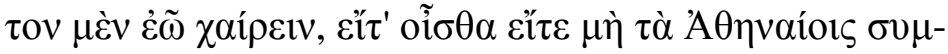

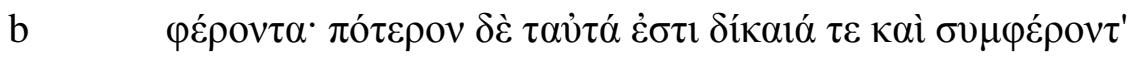

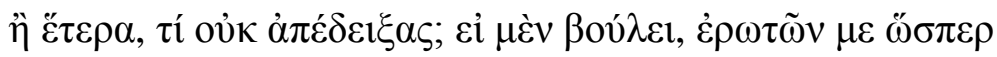

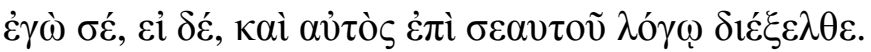

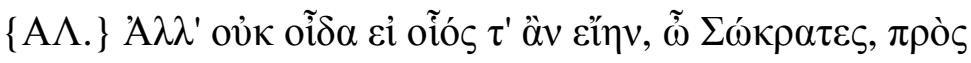
$\sigma \grave{\varepsilon} \delta 1 \varepsilon \lambda \theta \varepsilon \tilde{v}$.

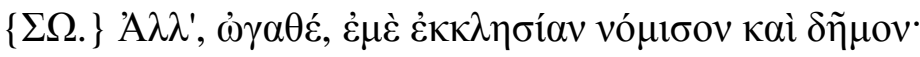

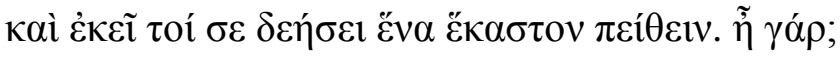

\{A^.\} Naí.

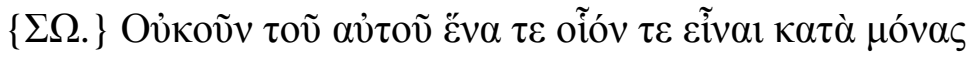

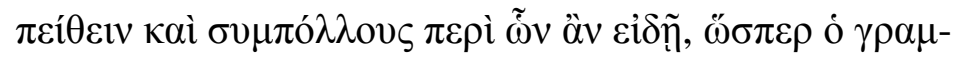

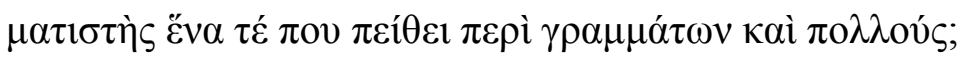

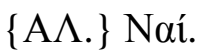

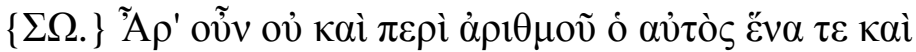

$5 \quad \pi \mathrm{o} \lambda \lambda \circ \mathrm{ò} \varsigma \pi \varepsilon i ́ \sigma \varepsilon \varepsilon$

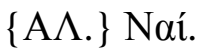

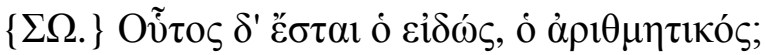

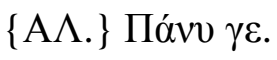

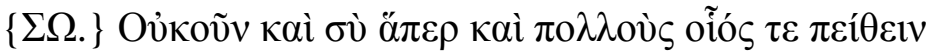

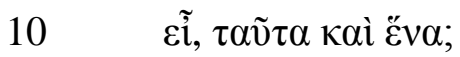

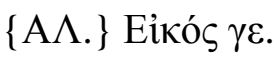

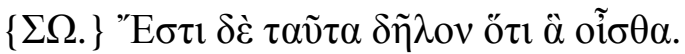

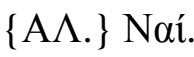

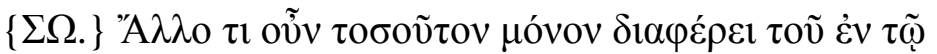


para conhecer o que é vantajoso e quem foi o professor, e tudo aquilo que anteriormente perguntei em uma única questão. Mas é claro que você chegará ao mesmo ponto e que não poderá responder que conhece o que é vantajoso por ter descoberto ou por ter aprendido. Contudo, já que você é refinado e não mais provaria com prazer o mesmo argumento, vou deixar de lado se conhece ou não o que é vantajoso aos atenienses. Por que não demonstra, então, que o que é justo e o que é vantajoso são a mesma coisa ou coisas diferentes? Se quiser, pode formular perguntas a mim como fiz com você, mas, se preferir, pode expor seu próprio argumento.

[ALC.] Mas eu não sei se eu conseguiria expor meu argumento diante de você, Sócrates.

[SÓC.] Então, bom homem, considere-me como se eu fosse a assembleia e o povo, pois lá você deverá persuadir a cada indivíduo. Ou não?

[ALC.] Sim.

[SÓC.] Então, o mesmo indivíduo não é capaz de persuadir tanto uma pessoa separadamente quanto todas juntas a respeito daquilo que conhece, c da mesma forma que o mestre persuade a respeito das letras tanto uma única quanto várias pessoas?

[ALC.] Sim.

[SÓC.] Acaso, então, o mesmo indivíduo não é capaz de persuadir também a respeito dos números tanto uma única quanto várias pessoas?

[ALC.] Sim.

[SÓC.] E esse indivíduo não será aquele que conhece, o aritmético?

[ALC.] Certamente.

[SÓC.] Então, também você não é capaz de persuadir uma única pessoa daquilo que é capaz de persuadir várias delas?

[ALC.] É plausível.

[SÓC.] E é evidente que essas matérias são aquelas que você conhece.

[ALC.] Sim.

[SÓC.] Então, há outra coisa, além disto, que diferencia 


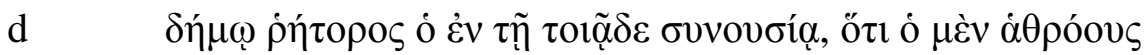

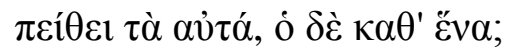

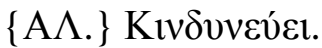

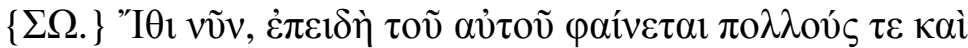

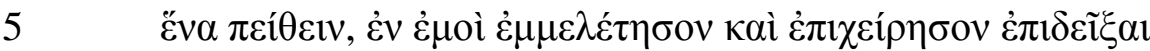

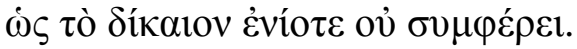

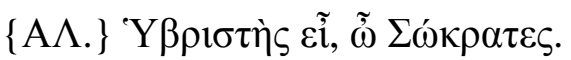

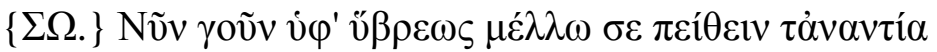

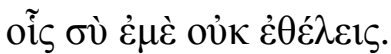

$10 \quad\{\mathrm{~A} \Lambda.\} \Lambda \varepsilon \dot{\gamma \varepsilon} \delta \dot{\eta}$.

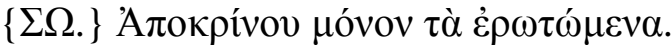

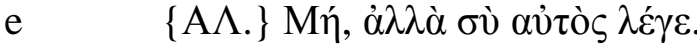

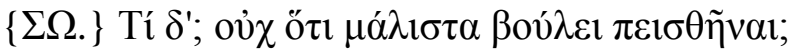

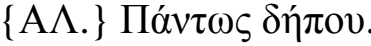

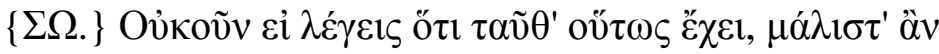

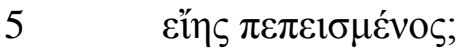

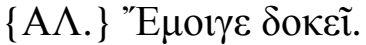

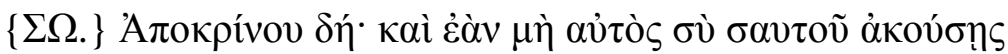

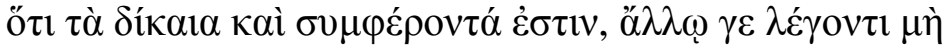
$\pi \imath \sigma \tau \varepsilon v ́ \sigma \eta ฺ$ s.

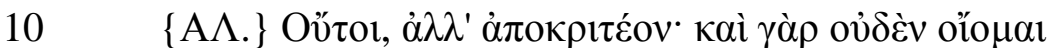
$\beta \lambda \alpha \beta \eta ́ \sigma \varepsilon \sigma \theta \alpha$ l.

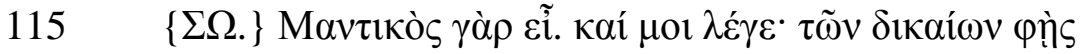

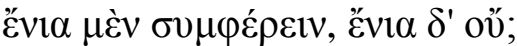

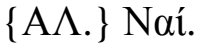

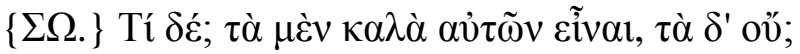

$5 \quad\{\mathrm{~A} \Lambda.\} \Pi \tilde{\omega} \varsigma \tau \sigma \tilde{\tau} \tau \mathrm{\varepsilon} \rho \omega \tau \tilde{\alpha} \varsigma ;$

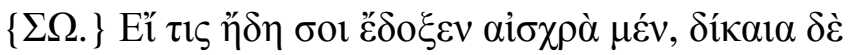
$\pi \rho \alpha ́ \tau \tau \varepsilon ı v ;$ 
o orador público de alguém neste tipo de intercurso: enquanto o primeiro persuade multidões, o segundo persuade cada um individualmente a respeito das mesmas questões?

[ALC.] É bem possível.

[SÓC.] Vamos lá! Uma vez que parece próprio do mesmo indivíduo persuadir tanto várias pessoas quanto uma individualmente, exercite-se comigo e tente mostrar que o justo algumas vezes não é vantajoso!

[ALC.] Como você é insolente, Sócrates.

[SÓC.] De fato, com insolência estou pronto para persuadi-lo do oposto daquilo que você não deseja me persuadir.

[ALC.] Diga-me então!

[SÓC.] Apenas responda ao que for questionado!

[ALC.] Não. Fale você mesmo!

[SÓC.] O quê? Você não quer ser persuadido ao máximo?

[ALC.] Com toda certeza!

[SÓC.] Então, se você diz que tal coisa é de tal maneira, não estaria persuadido ao máximo?

[ALC.] Parece-me que sim.

[SÓC.] Então responda! E se você próprio não ouvir de si mesmo que o que é justo é vantajoso, não acredite nas palavras de outrem!

[ALC.] Certamente não. Devo responder, pois penso que em nada me prejudicará.

[SÓC.] Que adivinho você é! Responda-me: você afirma que certas coisas justas são vantajosas, enquanto outras não o são?

[ALC.] Sim.

[SÓC.] E então? E dentre elas, algumas são belas e outras não?

[ALC.] O que você quer dizer com isso?

[SÓC.] Se alguém já lhe pareceu ter praticado atos vergonhosos, porém justos. 


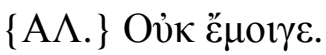

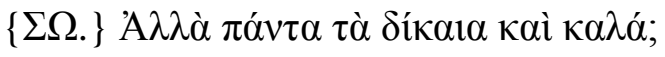

$10 \quad\{$ A $\Lambda$.$\} Naí.$

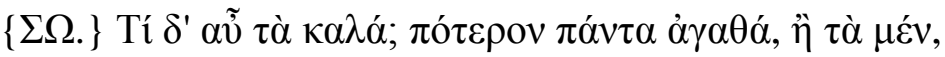
$\tau \grave{\alpha} \delta^{\prime}$ oü;

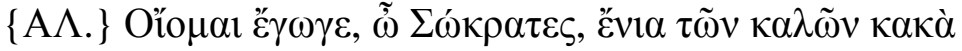

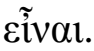

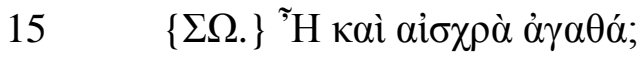

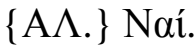

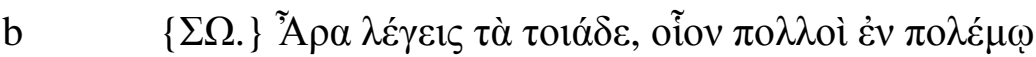

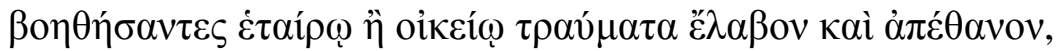

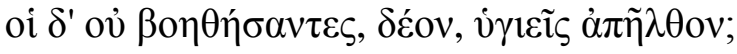

$\{\mathrm{A} \Lambda$.$\} Пóvv \mu \dot{\varepsilon} v$ ỡv.

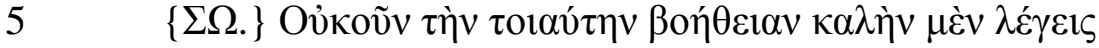

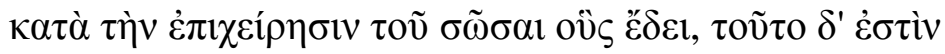

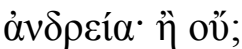

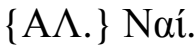

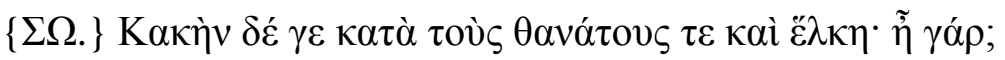

$10\{$ A $\Lambda$.$\} Naí.$

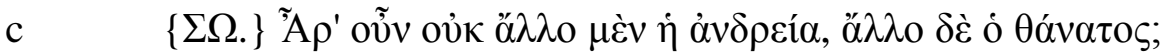

$\{\mathrm{A} \Lambda.\} \Pi^{\alpha} v v \gamma \varepsilon$.

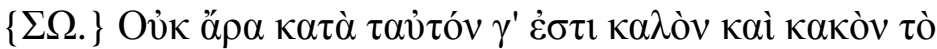

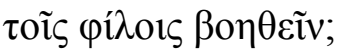

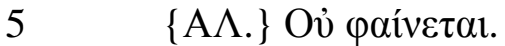

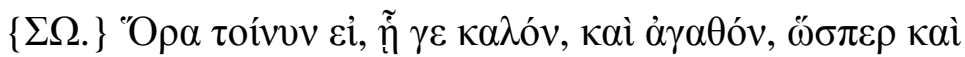

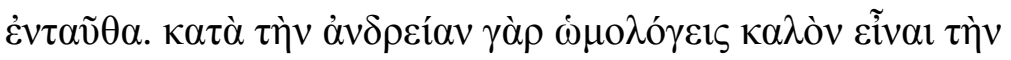

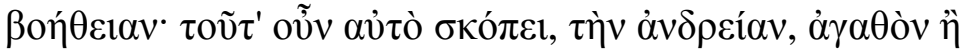

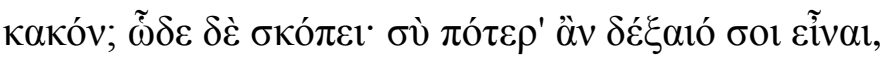

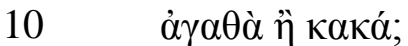


[ALC.] Nunca.

[SÓC.] Mas todas as coisas justas são também belas?

[ALC.] Sim.

[SÓC.] E as coisas belas, por sua vez? Todas elas são boas, ou umas o são, enquanto outras não?

[ALC.] Ao menos eu penso, Sócrates, que certas coisas belas são más.

[SÓC.] E também que certas coisas vergonhosas são boas?

[ALC.] Sim.

[SÓC.] Acaso se refere a casos como estes, quando muitos homens, por tentarem salvar um companheiro ou parente na guerra, acabam feridos ou mortos, enquanto outros, por não tentarem salvá-los, como era devido, retornam ilesos?

[ALC.] Certamente.

[SÓC.] Então, você diz que esse tipo de socorro é belo tendo em vista a tentativa de salvar a quem era devido, e que isso é coragem. Ou não?

[ALC.] Sim.

[SÓC.] E que é mau tendo em vista a morte e as feridas. Não é?

[ALC.] Sim.

[SÓC.] Acaso não é a coragem uma coisa, e a morte outra?

[ALC.] Certamente.

[SÓC.] Portanto, não é em vista da mesma coisa que é belo e mau o socorro aos amigos.

[ALC.] Não parece ser.

[SÓC.] Observe então se, na medida em que é belo, também é bom, como sucede inclusive neste caso. Bem, você concordou que o socorro é belo em vista da coragem. Então considere precisamente a coragem, se ela é boa ou má! Examine assim: você admitiria possuir coisas boas, ou coisas más? 
$\{\mathrm{A} \Lambda$.$\} 'A \gamma \alpha \theta \alpha \dot{ }$.

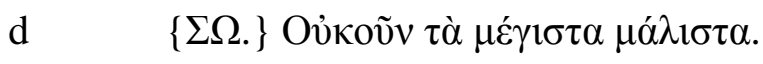

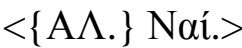

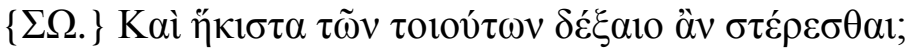

$\{\mathrm{A} \Lambda.\} \Pi \tilde{\omega} \varsigma \gamma \grave{\alpha} \rho$ oü;

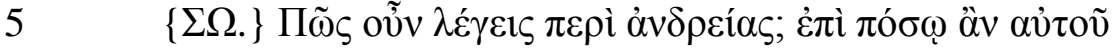

$\delta \varepsilon \dot{\xi} \xi \alpha 10 \sigma \tau \varepsilon \dot{\varepsilon} \rho \varepsilon \sigma \theta \alpha 1 ;$

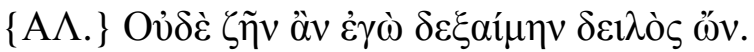

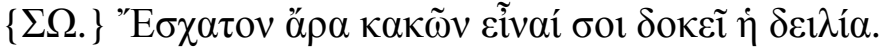

$\{\mathrm{A} \Lambda.\}{ }^{\prime} \mathrm{E} \mu \mathrm{ol} \gamma \varepsilon$.

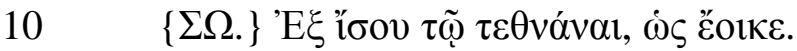

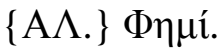

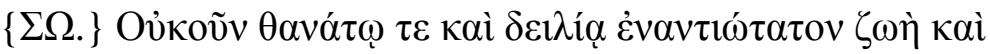
àv $\delta \rho \varepsilon i ́ \alpha ;$

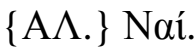

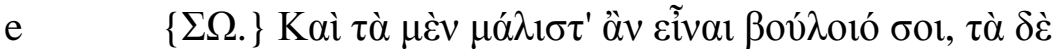
$\eta \dddot{\kappa} \kappa \iota \tau \alpha ;$

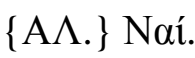

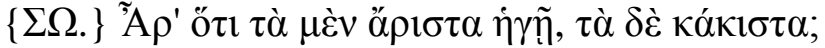

5

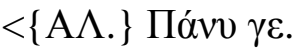

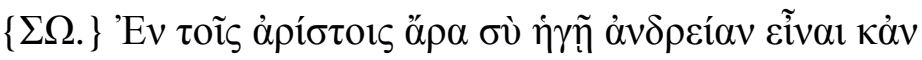

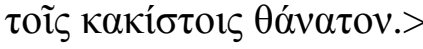

$\{\mathrm{A} \Lambda.\}{ }^{\prime} \mathrm{E} \gamma \omega \gamma \varepsilon$.

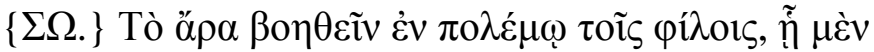

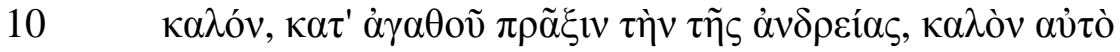
$\pi \rho о \sigma \varepsilon \tilde{i} \pi \alpha \zeta$

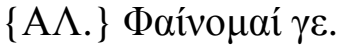

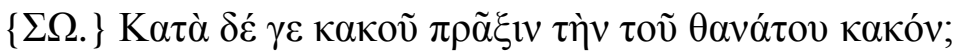

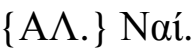


[ALC.] Coisas boas.

[SÓC.] E as maiores, sobretudo.

[ALC.] Sim.

[SÓC.] E delas menos admitiria ser privado?

[ALC.] Como não?

[SÓC.] Então, o que você diria da coragem? Em que medida você admitiria ser privado dela?

[ALC.] Eu não admitiria viver, se fosse covarde.

[SÓC.] Portanto, a covardia lhe parece ser o mal mais extremo.

[ALC.] Sim, de fato.

[SÓC.] Igualmente à morte, ao que parece.

[ALC.] Confirmo.

[SÓC.] Então, a vida e a coragem não são os extremos opostos da morte e da covardia?

[ALC.] Sim.

[SÓC.] E as primeiras você desejaria possuir acima de tudo, enquanto as segundas, o mínimo possível?

[ALC.] Sim.

[SÓC.] Porventura, porque julga aquelas as melhores coisas, enquanto estas as piores?

[ALC.] Com certeza.

[SÓC.] Portanto, você considera que a coragem está entre as melhores coisas, e a morte, entre as piores.

[ALC.] Ao menos eu, sim.

[SÓC.] Portanto, socorrer amigos na guerra você considera algo belo, por um lado, na medida em que é belo, por ser um ato de uma coisa boa, ou seja, um ato de coragem.

[ALC.] Claro que sim.

[SÓC.] E mau, por outro, por ser um ato de uma coisa má, ou seja, da morte.

[ALC.] Sim. 


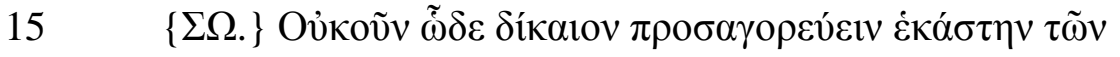

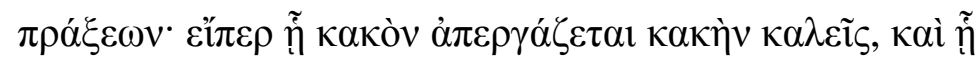

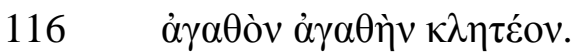

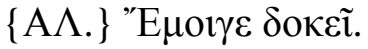

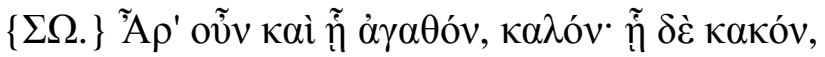

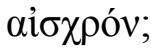

$5 \quad\{$ A $\Lambda$.$\} Naí.$

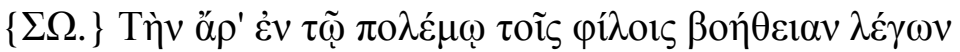

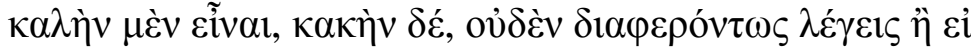

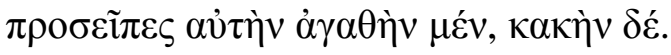

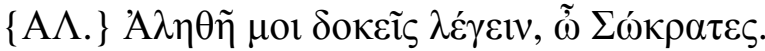

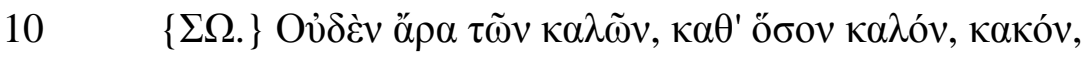

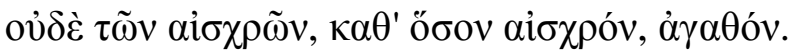

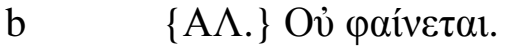

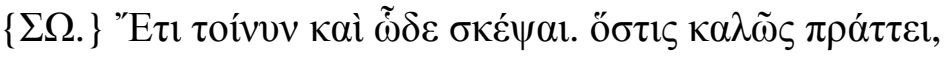

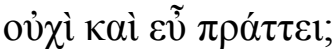

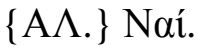

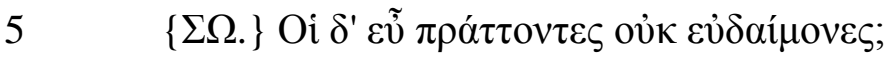

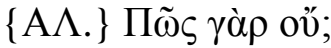

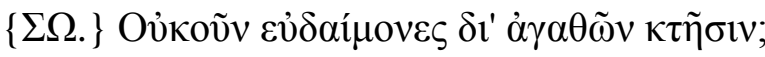

$\{\mathrm{A} \Lambda.\} \mathrm{M} \alpha \dot{\lambda} \imath \tau \tau \alpha$.

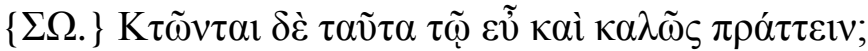

$10 \quad\{$ A $\Lambda$.$\} Naí.$

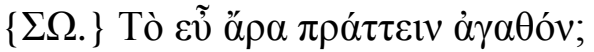

$\{\mathrm{A} \Lambda.\} \Pi \tilde{\omega} \varsigma \delta^{\prime}$ ov้;

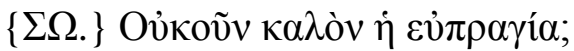

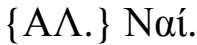

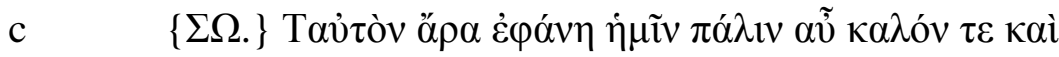

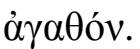


[SÓC.] Então, é justo que se designe cada um dos atos da seguinte maneira: se você denomina um ato mau, na medida em que produz algum mal, também se deve denominar um ato bom, na medida em que produz algum bem.

[ALC.] Parece-me que sim.

[SÓC.] Acaso, então, na medida em que é bom, também é belo? E na medida em que é mau, é vergonhoso?

[ALC.] Sim.

[SÓC.] Portanto, ao afirmar que o socorro aos amigos na guerra é um ato belo, porém mau, é o mesmo que dizer que um ato é bom, porém mau.

[ALC.] Parece-me que você diz a verdade, Sócrates.

[SÓC.] Portanto, nenhum ato belo, na medida em que é belo, é mau, ao passo que nenhum ato vergonhoso, na medida em que é vergonhoso, é bom.

[ALC.] É claro que não.

[SÓC.] Pois bem, considere ainda o seguinte: quem quer que aja de maneira bela, não estará também agindo bem?

[ALC.] Sim.

[SÓC.] E aqueles que agem bem não são felizes?

[ALC.] Como não seriam?

[SÓC.] E não são felizes pela posse de coisas boas?

[ALC.] Com toda certeza!

[SÓC.] E eles as adquirem por agirem bem e de modo belo?

[ALC.] Sim.

[SÓC.] Portanto, agir bem é bom?

[ALC.] Como não?

[SÓC.] E é bela a boa ação?

[ALC.] Sim.

[SÓC.] Portanto, mostrou-se a nós, novamente, que belo e bom são a c mesma coisa. 


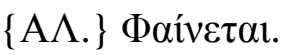

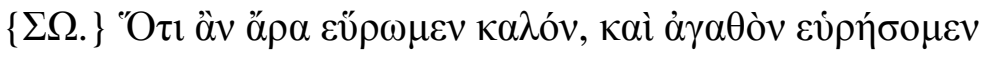

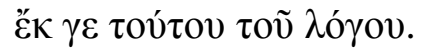

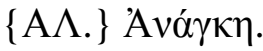

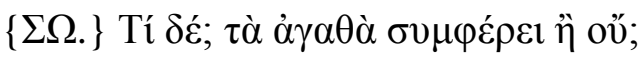

$\{\mathrm{A} \Lambda.\} \Sigma v \mu \varphi \varepsilon ́ \rho \varepsilon 1$.

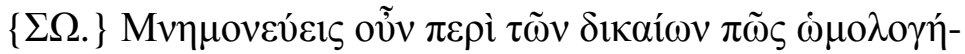

$10 \quad \sigma \alpha \mu \varepsilon v$

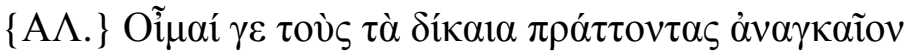

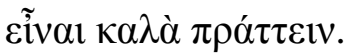

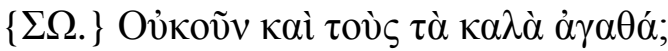

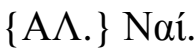

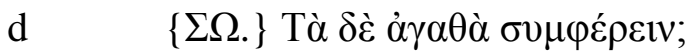

\{A^.\} Naí.

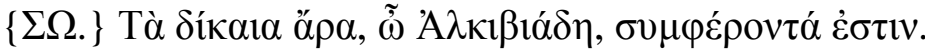

$\{\mathrm{A} \Lambda.\}{ }^{\prime}$ Eо1кеv.

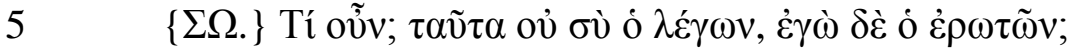

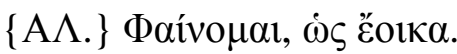

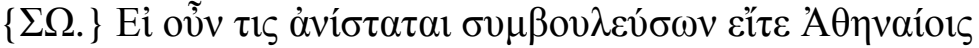

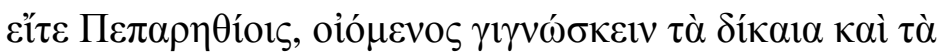

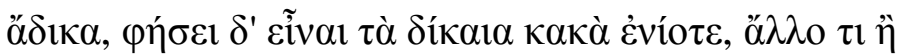

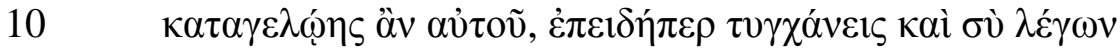

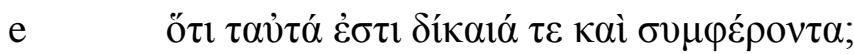

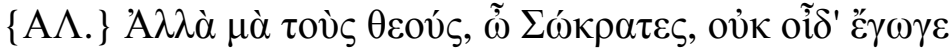

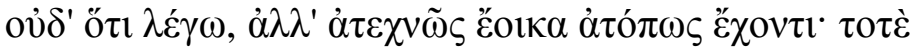

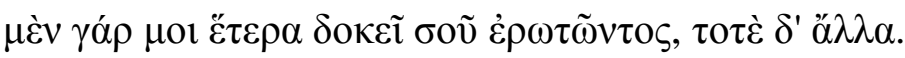

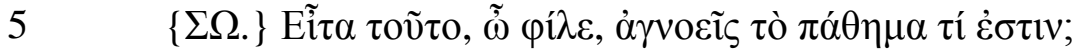
$\{\mathrm{A} \Lambda.\} \Pi \alpha \dot{v v v} \gamma \varepsilon$.

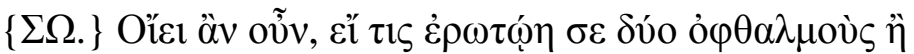


[ALC.] É claro.

[SÓC.] Portanto, o que descobrirmos ser belo, também o descobriremos ser bom conforme esse argumento.

[ALC.] É forçoso.

[SÓC.] E então? As coisas boas são vantajosas ou não?

[ALC.] São vantajosas.

[SÓC.] Você recorda o que concordamos a respeito dos atos justos?

[ALC.] Penso que era assim: aqueles que praticam atos justos praticam necessariamente atos belos.

[SÓC.] Então, os que praticam atos belos não praticam necessariamente atos bons?

[ALC.] Sim.

[SÓC.] E são vantajosos esses atos bons?

[ALC.] Sim.

[SÓC.] Portanto, Alcibíades, as coisas justas são vantajosas.

[ALC.] É plausível.

[SÓC.] E então? Não é você quem diz, enquanto eu apenas o interrogo?

[ALC.] Sou eu sim, ao que parece.

[SÓC.] Se, então, alguém se levantar para aconselhar quer os atenienses quer os peparécios, julgando conhecer o que é justo e o que é injusto, e disser que as coisas justas às vezes são más, não é verdade que você riria dele, uma vez que também você afirma que as mesmas coisas são justas e e vantajosas?

[ALC.] Mas pelos deuses, Sócrates! Eu não sei nem mesmo o que estou dizendo, mas pareço encontrar-me numa condição simplesmente absurda. Em uma ocasião, enquanto você perguntava, parecia-me uma coisa, e em outra, coisa diferente.

[SÓC.] E então, meu caro, você ignora que condição é essa?

[ALC.] Certamente.

[SÓC.] O que você acha? Se alguém lhe perguntasse se você tem dois olhos ou 


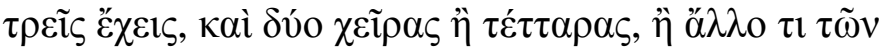

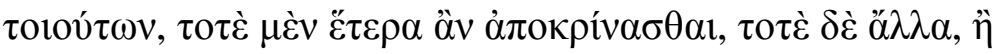

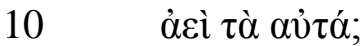

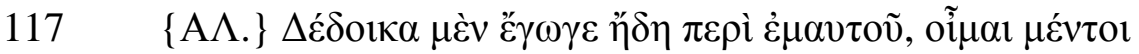

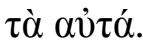

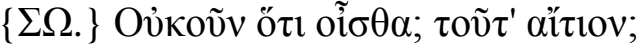

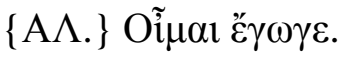

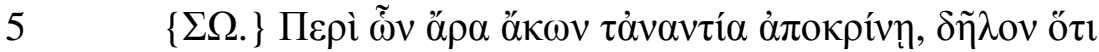

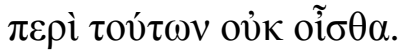

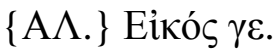

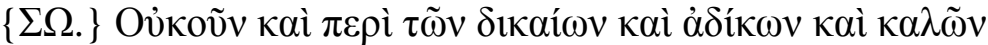

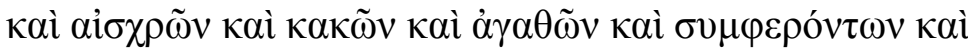

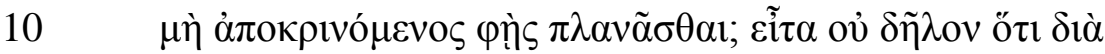

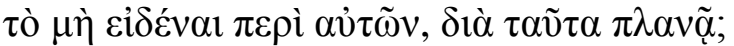

b $\quad\{\mathrm{A} \Lambda.\}{ }^{\prime} \mathrm{E} \mu \mathrm{ol \gamma \varepsilon}$.

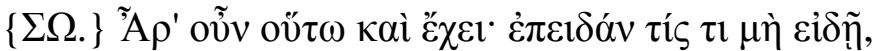

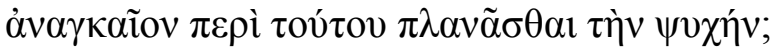

$\{\mathrm{A} \Lambda.\} \Pi \tilde{\omega} \varsigma \gamma \grave{\alpha} \rho$ oṽ;

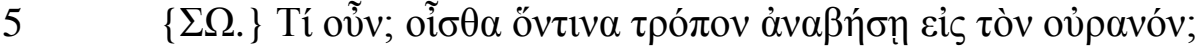

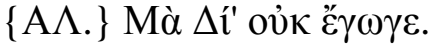

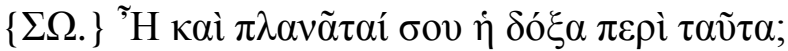

$\{\mathrm{A} \Lambda$.$\} O \delta \tilde{\eta} \tau \alpha$.

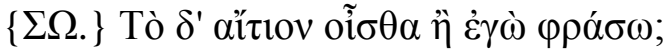

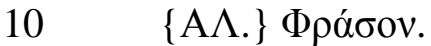

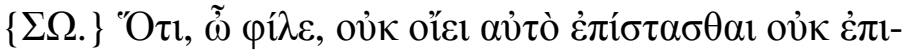

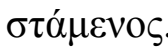

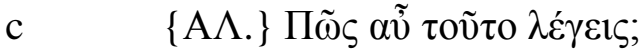

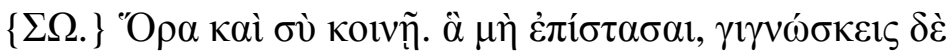

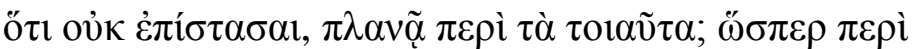


três, duas mãos ou quatro, ou qualquer questão desse tipo, você responderia ora uma coisa, ora outra, ou sempre as mesmas coisas?

[ALC.] Já estou com receio de mim mesmo, porém penso que responderia as mesmas coisas.

[SÓC.] E não é porque sabe a resposta? É essa a razão?

[ALC.] Penso que sim.

[SÓC.] A respeito, portanto, daquilo a que você involuntariamente oferece respostas contrárias, é evidente que não o conhece.

[ALC.] É bem plausível.

[SÓC.] E quando você responde acerca do que é justo e injusto, belo e vergonhoso, mau e bom, vantajoso e desvantajoso, você não diz hesitar? Nesse caso, não é evidente que sua hesitação se deve à sua ignorância a respeito delas?

[ALC.] Sim.

[SÓC.] Porventura não é isto que sucede: quando alguém não possuir conhecimento de algo, é forçoso que sua alma hesite nisso?

[ALC.] E como não?

[SÓC.] E então? Conhece alguma maneira de subir para o céu?

[ALC.] Por Zeus, eu não.

[SÓC.] Também nesse caso sua opinião é hesitante?

[ALC.] Não mesmo.

[SÓC.] Sabe a razão ou devo dizê-la?

[ALC.] Diga-me!

[SÓC.] É porque, meu caro, você não julga conhecer o assunto sem conhecê-lo.

[ALC.] E agora, o que você quer dizer com isso?

[SÓC.] Observe comigo! Sobre o que você não conhece, mas reconhece que desconhece, acaso hesita em tais coisas? Por exemplo, sobre 
ő

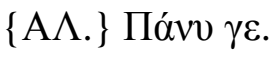

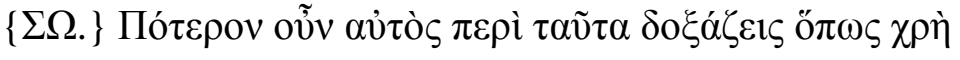

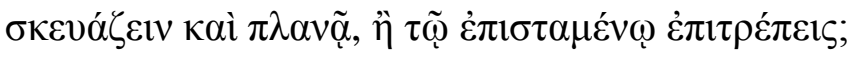

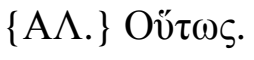

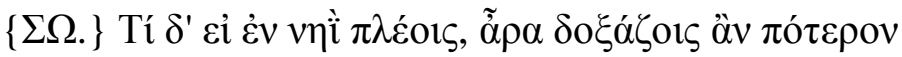

d

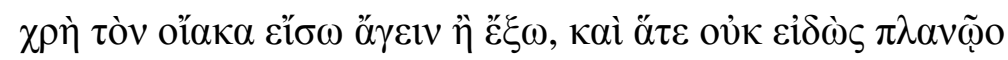

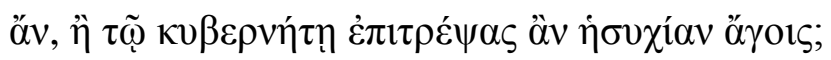

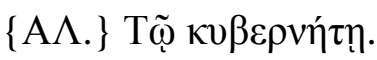

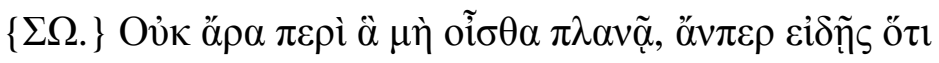

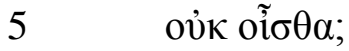

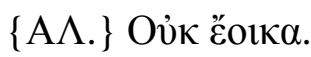

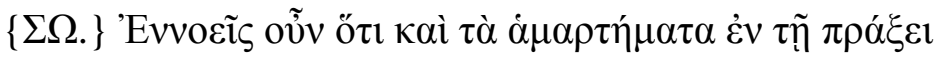

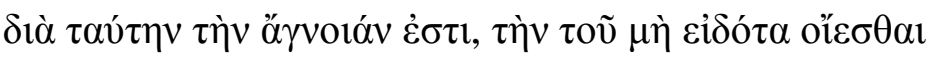

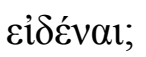

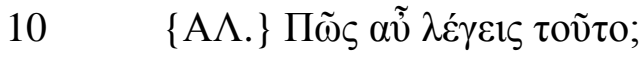

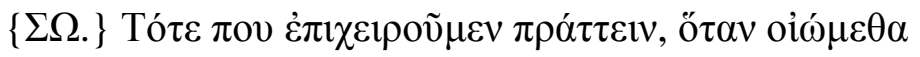

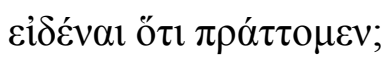

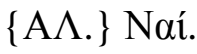

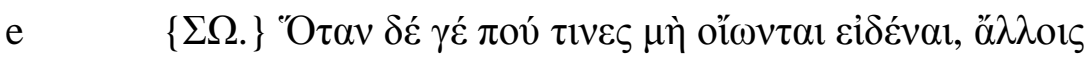
$\pi \alpha \rho \alpha \delta \imath \delta$ ó $\alpha \sigma \mathrm{l}$

$\{\mathrm{A} \Lambda.\} \Pi \tilde{\omega} \varsigma \delta^{\prime}$ ov̈;

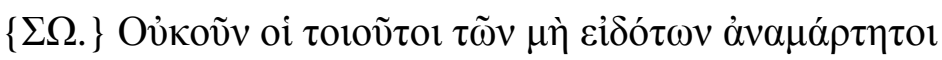

$5 \quad \zeta \tilde{\omega} \sigma \mathrm{l} \delta$ ì̀ $\tau$ ò

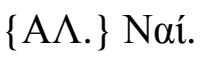

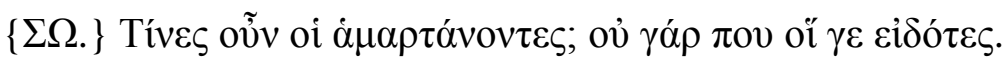

$\{\mathrm{A} \Lambda$.$\} Ov̉ \delta \tilde{\eta} \tau \alpha$.

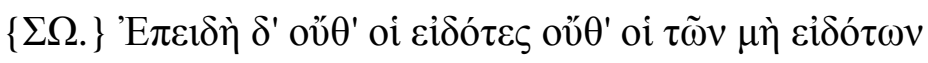

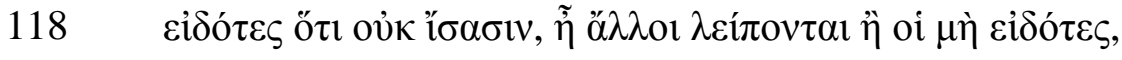


o preparo de alimentos, certamente você sabe que não conhece isso, não é?

[ALC.] É claro.

[SÓC.] Então, você próprio conjetura como se deve preparar o alimento e fica desnorteado, ou confia o preparo a quem sabe fazê-lo?

[ALC.] A quem sabe fazê-lo.

[SÓC.] E o que faria se estivesse navegando? Acaso conjeturaria como é preciso conduzir o leme, para dentro ou para fora, e, por não sabê-lo, ficaria $d$ desnorteado, ou confiaria isso ao capitão e ficaria em silêncio?

[ALC.] Confiaria ao capitão.

[SÓC.] Portanto, você não hesita naquilo que desconhece, caso reconheça que não conhece, não é?

[ALC.] Parece que não.

[SÓC.] Você tem em mente, então, que também os erros nas ações ocorrem devido a esta ignorância, a ignorância de se supor conhecer quando se desconhece?

[ALC.] E agora, o que você quer dizer com isso?

[SÓC.] Penso que nós intentamos pôr algo em prática, quando julgamos conhecer o que estamos fazendo, não é?

[ALC.] Sim.

[SÓC.] E penso que, quando as pessoas julgam que não conhecem algo, e entregam-no aos cuidados de outras pessoas, não é mesmo?

[ALC.] Como não?

[SÓC.] Então, dentre as pessoas desprovidas de conhecimento, não são essas que vivem sem incorrer em erros por confiarem aquilo que não sabem a outrem?

[ALC.] Sim.

[SÓC.] E quanto a quem comete erros? Eu suponho que não sejam aqueles que conhecem.

[ALC.] Não mesmo.

[SÓC.] Uma vez que não são os que conhecem e nem os que, por não conhecerem, reconhecem sua ignorância, não restam senão aqueles que não conhecem, 


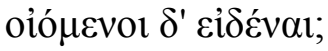

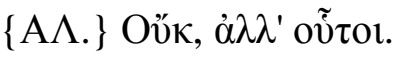

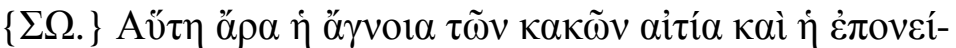

5

$\delta 1 \sigma \tau o \varsigma \dot{\alpha} \mu \alpha \theta \dot{\alpha} \alpha$

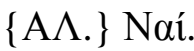

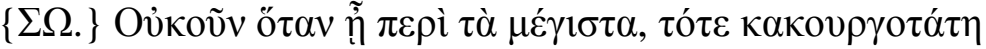

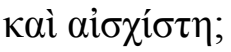

$\{\mathrm{A} \Lambda.\} \Pi о \lambda v ́ \gamma \varepsilon$.

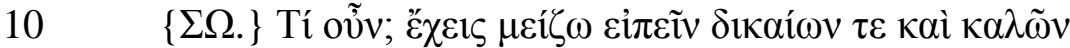

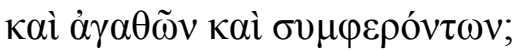

$\{\mathrm{A} \Lambda$.$\} O ̉ \delta \tilde{\eta} \tau \alpha$.

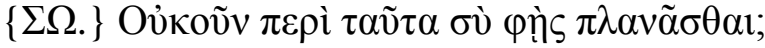

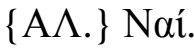

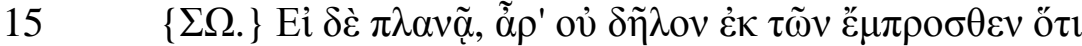

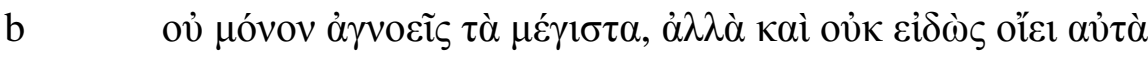

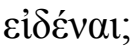

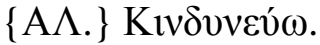

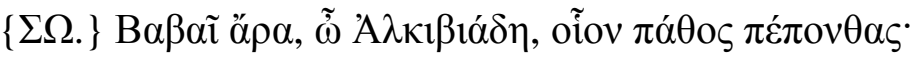

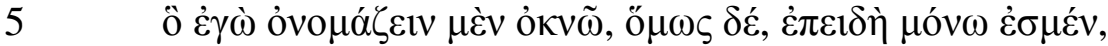

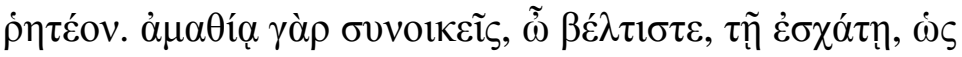

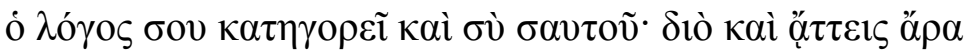

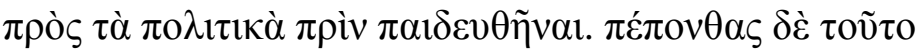

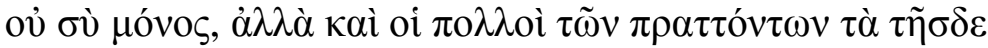

c

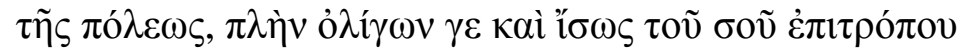

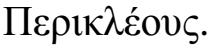

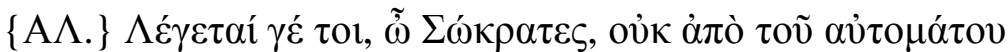

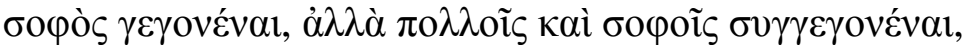

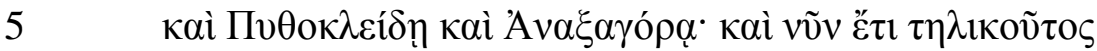

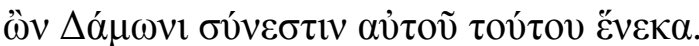


embora julguem conhecer?

[ALC.] Ninguém além desses.

[SÓC.] Portanto, é essa ignorância e essa estupidez censurável a causa dos males, não é?

[ALC.] Sim.

[SÓC.] E quando for relativa às coisas mais importantes, não será a mais nociva e a mais vergonhosa?

[ALC.] Com certeza.

[SÓC.] E então? Você é capaz de me dizer o que é mais importante do que o que é justo, belo, bom e vantajoso?

[ALC.] Certamente não.

[SÓC.] E então, não é nessas coisas que você admite hesitar?

[ALC.] Sim.

[SÓC.] E se você hesita nelas, não é evidente que, conforme o argumento anterior, não somente ignora as coisas mais importantes, como também $b$ julga conhecê-las embora não as conheça?

[ALC.] É bem possível.

[SÓC.] Ora, mas em que condição você se encontra, Alcibíades! Eu receio denominá-la; contudo, já que estamos sozinhos, devo dizê-lo. Pois você convive com a estupidez, excelente homem, com a extrema estupidez, como lhe acusa o seu argumento e você próprio. É por isso que você se lança como uma flecha na vida política antes de ter sido instruído. Você, contudo, não está sozinho nessa condição; muitos dos que se envolvem com a política nesta cidade também estão, com exceção de poucos e, talvez, do seu tutor, Péricles.

[ALC.] De qualquer maneira, ó Sócrates, dizem que ele se tornou sábio não por si só, mas por ter tido contato com muitos sábios, como Pitoclides e Anaxágoras. E agora, mesmo sendo velho, mantém contato com Damon em vista do mesmo propósito. 


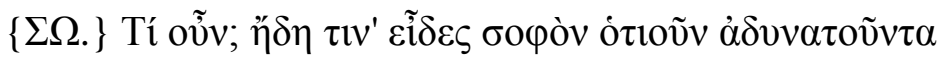

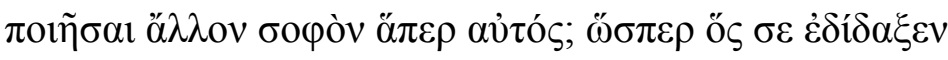

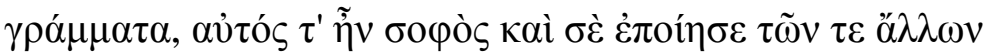

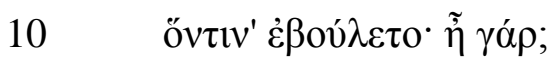

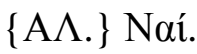

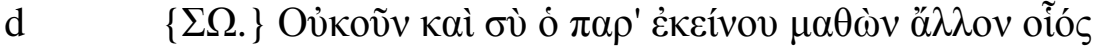
$\tau \varepsilon$ हैं๗ฺ;

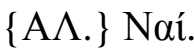

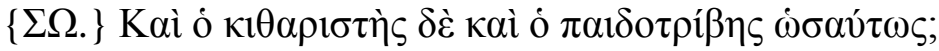

$\{\mathrm{A} \Lambda.\} \Pi^{\alpha} v v \gamma \varepsilon$.

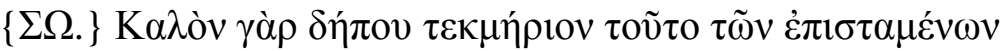

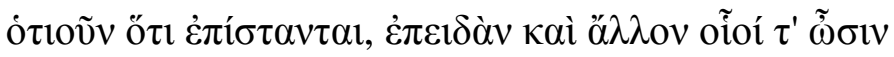
$\dot{\alpha} \pi \circ \delta \varepsilon \bar{i} \xi \alpha \imath \dot{\varepsilon} \pi \imath \tau \tau \alpha ́ \mu \varepsilon v o v$.

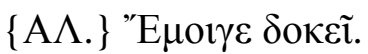

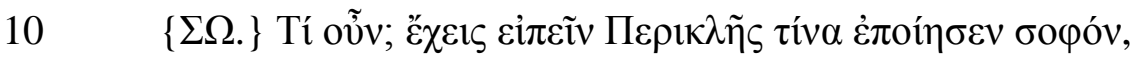

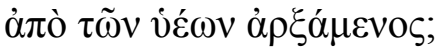

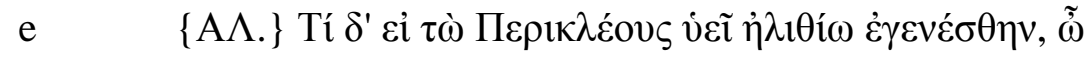
$\Sigma \omega ́ \kappa \rho \alpha \tau \varepsilon \varsigma ;$

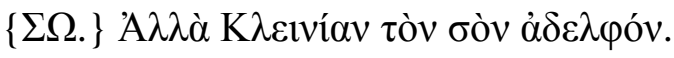

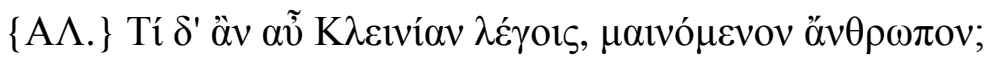

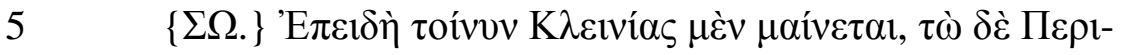

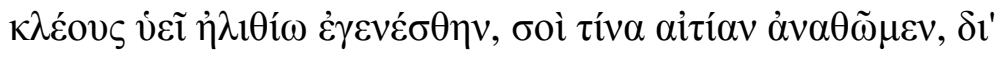

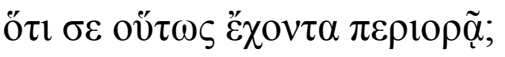

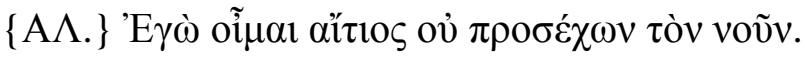

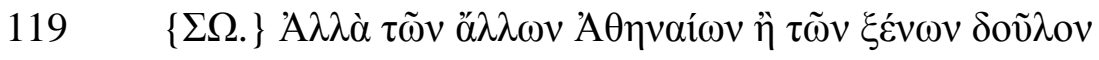

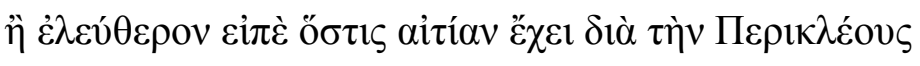

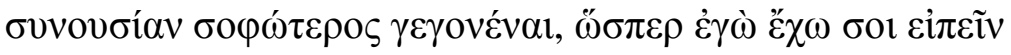

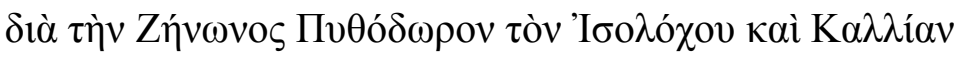

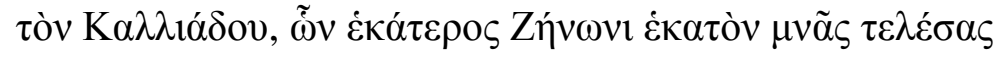


[SÓC.] E então? Você já viu algum sábio ser incapaz de transmitir sua própria sabedoria a outras pessoas? Por exemplo, aquele que lhe ensinou as letras: ele próprio não era sábio e não transmitiu sua sabedoria a você e a quem quer que ele quisesse?

[ALC.] Sim.

[SÓC.] E também não será você capaz de transmitir a outrem o que d aprendera junto a ele?

[ALC.] Sim.

[SÓC.] E da mesma maneira também o citarista e o treinador?

[ALC.] Com certeza.

[SÓC.] Pois certamente isto é uma bela evidência de que aqueles que conhecem alguma coisa de fato a conhecem: quando são capazes de mostrar que também outra pessoa a conhece.

[ALC.] Eu concordo.

[SÓC.] E então? Você pode dizer se Péricles tornou alguém sábio, a começar pelos filhos?

[ALC.] Mas por que os filhos de Péricles, Sócrates, se eles se tornaram insensatos?

[SÓC.] E quanto a Clínias, o seu irmão?

[ALC.] Mas por que você mencionaria Clínias, um homem louco?

[SÓC.] Mas já que Clínias é um louco, e ambos os filhos de Péricles se tornaram insensatos, que causa devemos atribuir ao fato de ele tolerar que você se encontre nessa condição?

[ALC.] Eu penso que sou eu o culpado por não lhe prestar atenção.

[SÓC.] Mas aponte-me quem quer que, dentre os demais atenienses ou dentre os estrangeiros, seja ele escravo ou homem livre, tenha se tornado mais sábio devido ao convívio com Péricles, do mesmo modo que eu posso lhe dizer de Pitodoro, filho de Isóloco, e de Cálias, filho de Calíades, os quais, devido ao convívio com Zenão, cada qual lhe tendo pagado cem minas, 


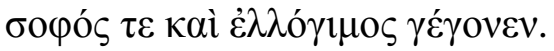

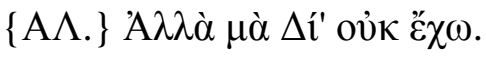

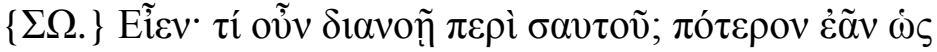

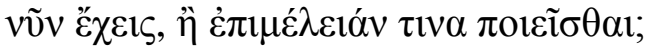

b

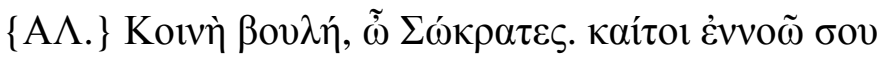

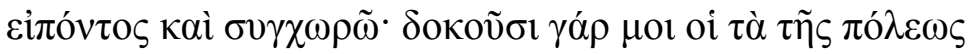

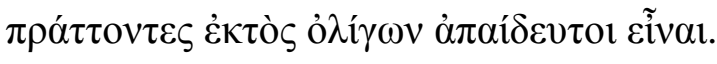

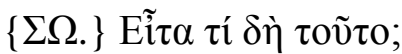

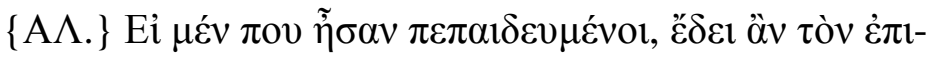

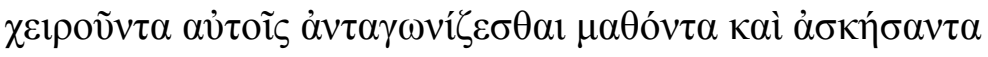

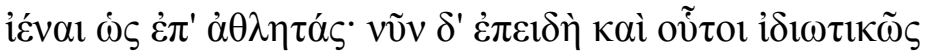

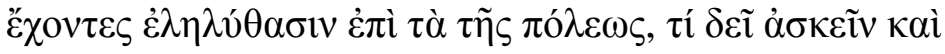

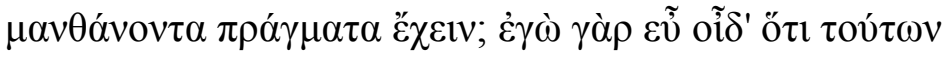

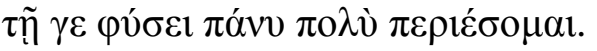

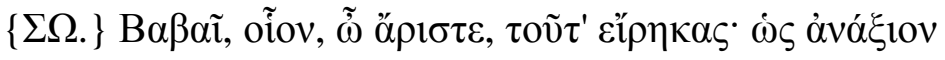

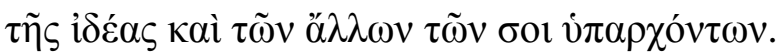

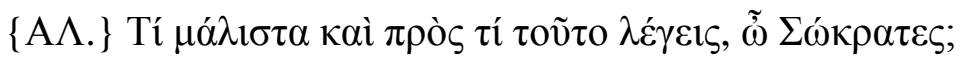

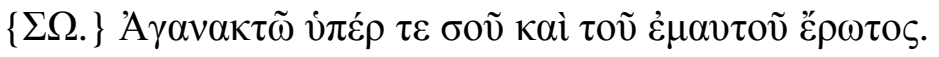

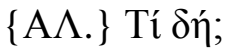

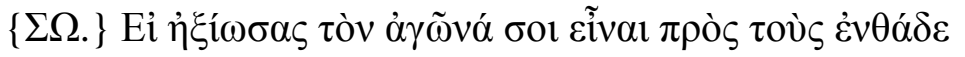
$\dot{\alpha} v \theta \rho \omega ́ \pi 0 v \varsigma$.

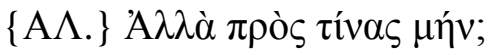

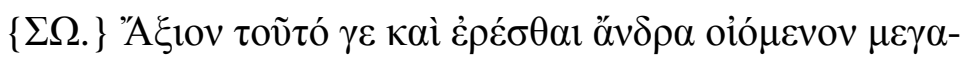

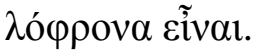

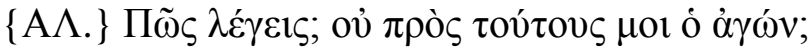

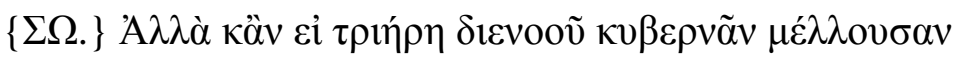

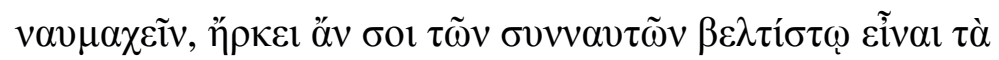

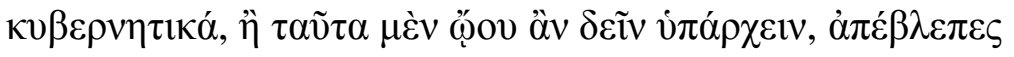

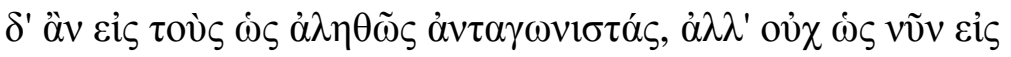


se tornaram sábios e bem reputados.

[ALC.] Por Zeus, eu não posso apontar ninguém.

[SÓC.] Seja! Então, o que você pretende fazer de si mesmo? Permanecer na sua presente condição, ou providenciar algum cuidado?

[ALC.] Tomemos uma decisão em comum, Sócrates. De fato, reconheço as b suas palavras e concordo com elas. Pois os homens que praticam a política na cidade me parecem não ter instrução, com exceção de poucos.

[SÓC.] E o que isso significa?

[ALC.] Se, suponho eu, fossem instruídos, seria preciso a quem tentasse contestar-lhes investir contra eles depois de ter aprendido e se exercitado, como se fosse investir contra atletas. Todavia, uma vez que também eles se engajaram na política da cidade como leigos, por que é preciso exercitar-me e ter o aborrecimento de aprender? Pois eu bem sei que serei muitíssimo superior a eles devido à minha natureza.

[SÓC.] Ora ora, mas que resposta a sua, excelente homem! Quão indigna é de sua bela aparência e de seus demais recursos!

[ALC.] O que você quer dizer com isso, Sócrates, e em vista do quê?

[SÓC.] Estou indignado com você e com o meu próprio amor.

[ALC.] E por quê?

[SÓC.] Porque você considerou que o seu embate devia ser contra estes homens daqui.

[ALC.] Mas contra quem então?

[SÓC.] Quão digna de um homem que se julga tão magnânimo essa d pergunta!

[ALC.] O que você está dizendo? O meu embate não é contra eles?

[SÓC.] Se você intentasse conduzir uma trirreme para uma batalha naval, se contentaria em ser o melhor da tripulação no que se refere à arte da pilotagem? Ou você julga que isso seria uma condição precedente, e então voltaria sua atenção para os verdadeiros inimigos, mas não, como agora, para 


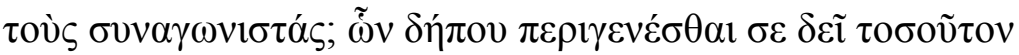

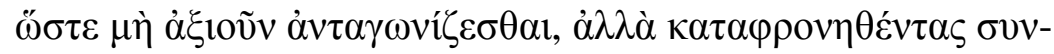

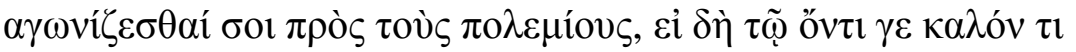

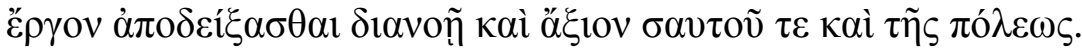

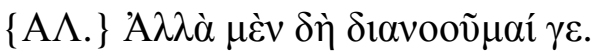

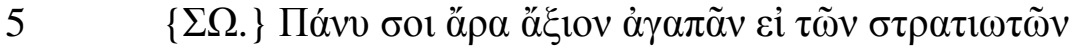

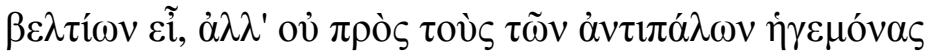

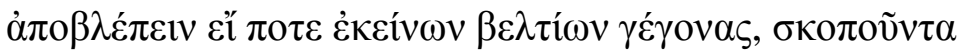

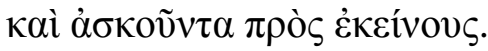

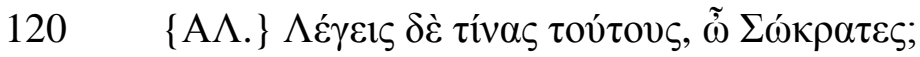

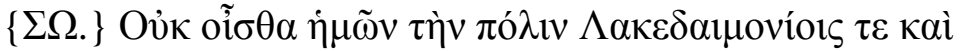

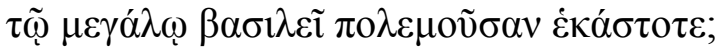

$\{\mathrm{A} \Lambda$.$\} 'A \lambda \eta \theta \tilde{\eta} \lambda \varepsilon \dot{\varepsilon \varepsilon \varepsilon 1 \zeta . ~}$

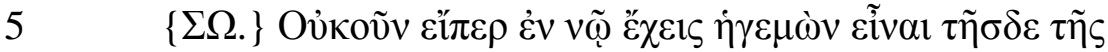

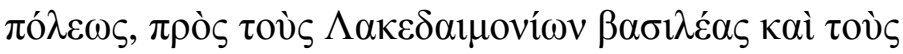

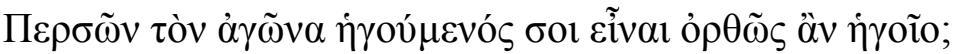

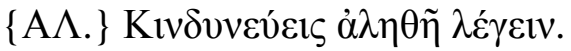

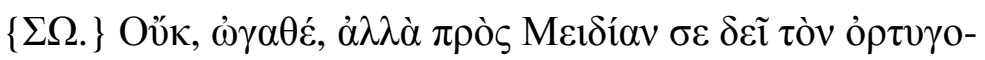

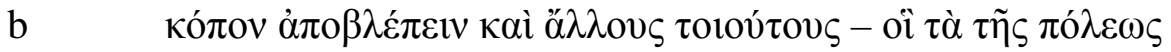

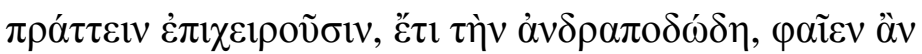

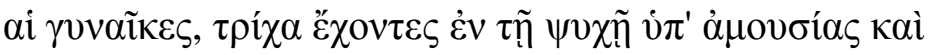

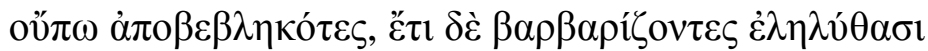

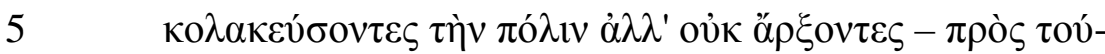

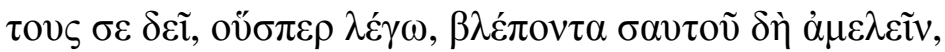

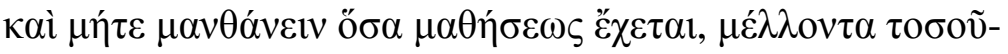

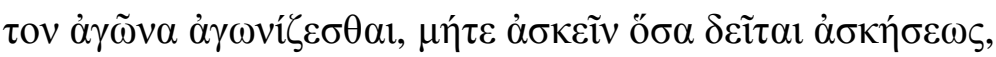

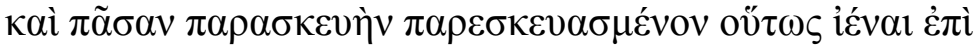
$\tau$ $\alpha \grave{\eta \eta ̄ \varsigma ~} \pi \hat{\lambda} \lambda \varepsilon \omega \varsigma$.

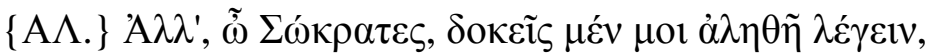


os seus aliados? Você deve, de fato, prevalecer sobre eles de tal maneira que eles próprios não se considerem dignos de disputar com você, mas, e sentindo-se inferiores, de se aliarem a você contra os inimigos, se você realmente planeja realizar um belo feito digno de si mesmo e da cidade.

[ALC.] Mas eu tenho sim essa pretensão!

[SÓC.] Portanto, lhe é muitíssimo conveniente contentar-se caso seja o melhor entre os soldados, e não observar os comandantes dos inimigos para ver se você já é melhor do que eles, examinando e se exercitando em vista deles.

[ALC.] A quem você se refere, Sócrates?

[SÓC.] Você não sabe que a nossa cidade trava ocasionalmente guerras contra os lacedemônios e o Grande Rei?

[ALC.] É verdade.

[SÓC.] Então, se você planeja ser o líder desta cidade, não é correto considerar que haverá de liderar a luta contra os reis dos lacedemônios e os dos persas?

[ALC.] É possível que você diga a verdade.

[SÓC.] Não, bom homem, mas é preciso que você observe Mídias, o galo de rinha, e outros como ele - os quais tentam se envolver com a política na cidade, possuindo ainda na alma cabelos curtos próprios de escravos, como diriam as mulheres, sem refinamento e sem terem se livrado deles, e ainda com trejeitos bárbaros se encaminham para adular a cidade, mas não para governá-la. É a esses homens que estou me referindo, é a eles que você deve observar e então descuidar de si próprio, e não aprender o que há para ser aprendido estando prestes a enfrentar uma luta de tamanha importância, tampouco praticar o que precisa ser praticado, entrando assim na vida política, uma vez garantida a sua preparação completa.

[ALC.] Bem, Sócrates, parece-me que você diz a verdade, 


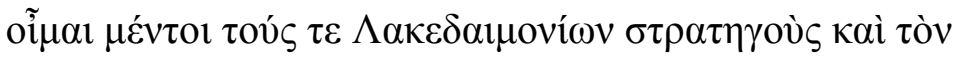

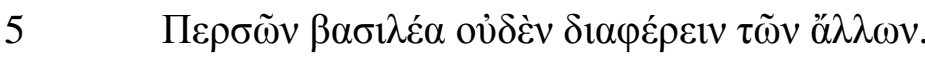

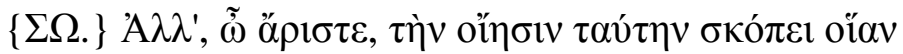

$\ddot{\varepsilon} \chi \varepsilon 1 \varsigma$.

$\{\mathrm{A} \Lambda$.$\} Toũ \pi \varepsilon ́ \rho 1 ;$

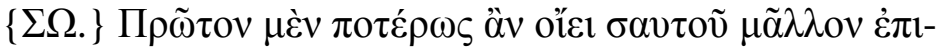

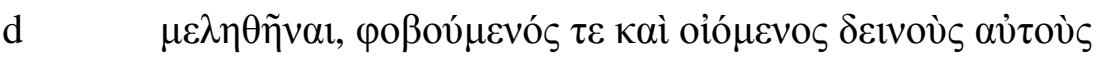

Eĩvol, ì $\mu$;́;

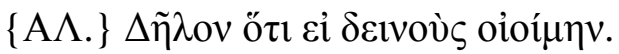

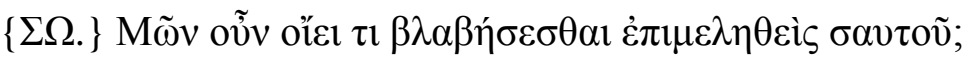

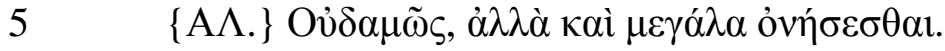

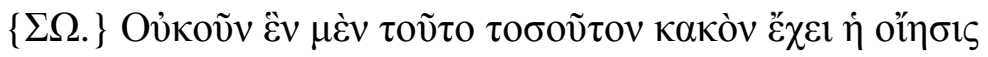
$\alpha$

$\{\mathrm{A} \Lambda.\} \mathrm{A} \lambda \eta \theta \tilde{\eta} \lambda \dot{\varepsilon} \gamma \varepsilon 1 \zeta$.

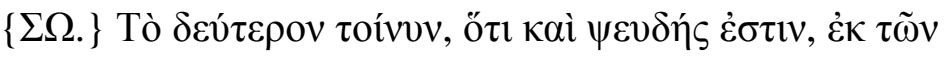

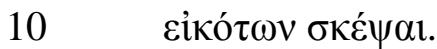

$\{\mathrm{A \Lambda . \}} \Pi \tilde{\omega} \varsigma \delta \dot{\gamma}$

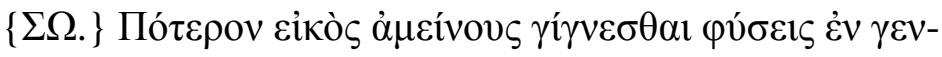

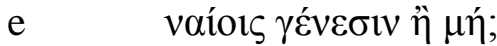

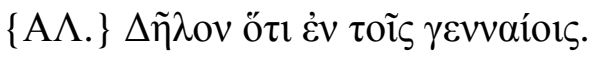

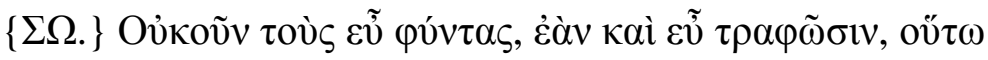

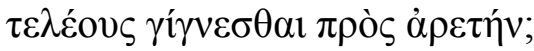

$5 \quad\{\mathrm{~A} \Lambda$.$\} 'Аขó \gamma \kappa \eta$.

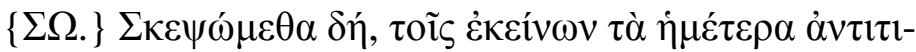

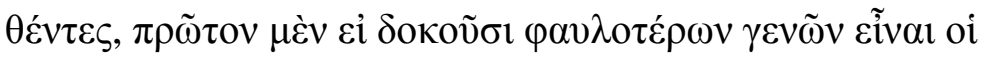

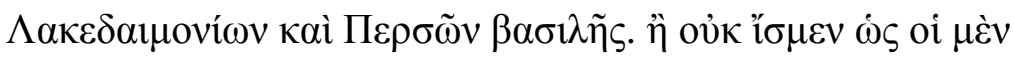

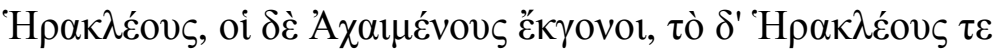

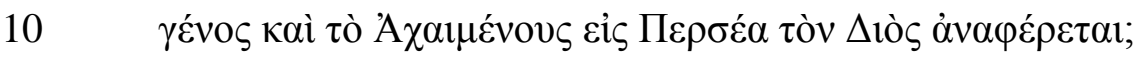

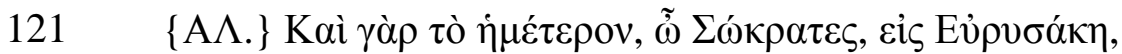


no entanto penso que nem os estrategos lacedemônios nem o rei persa diferem dos demais.

[SÓC.] Mas, excelente homem, examine que tipo de opinião é essa que você possui!

[ALC.] Sobre o quê?

[SÓC.] Em primeiro lugar, de que maneira você julga que cuidaria melhor de si mesmo: ao temê-los e considerá-los terríveis, ou o contrário?

[ALC.] É claro que se eu os considerasse terríveis.

[SÓC.] Porventura você julga que seria prejudicado em algo por cuidar de si mesmo?

[ALC.] De maneira alguma; pelo contrário, eu tiraria muito mais proveito disso.

[SÓC.] Então, aquela sua opinião carrega consigo esse único mal, que é tremendo.

[ALC.] É verdade o que você diz.

[SÓC.] Pois bem, em segundo lugar, que ela é também falsa, examine segundo as probabilidades!

[ALC.] Como?

[SÓC.] É provável que as melhores naturezas surjam entre as nobres estirpes, ou não?

[ALC.] É claro que entre as nobres estirpes.

[SóC.] Então, aqueles que possuem uma boa natureza, se forem bem educados, não se tornarão perfeitos em virtude?

[ALC.] Necessariamente.

[SÓC.] Examinemos então, primeiramente, se os lacedemônios e os reis persas parecem ser de origem inferior, comparando nossa condição com a deles! Ou não sabemos que os primeiros são descendentes de Héracles e os segundos de Aquêmenes, e que tanto a linhagem de Héracles quanto a linhagem de Aquêmenes remontam a Perseu, filho de Zeus?

[ALC.] Também a minha linhagem, Sócrates, remonta a Eurísaques, 


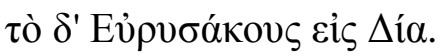

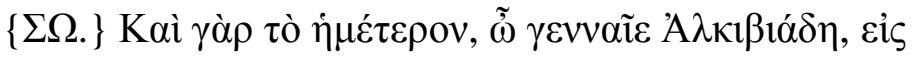

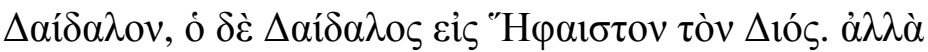

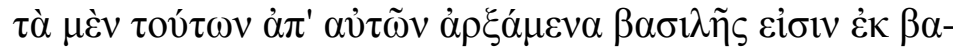

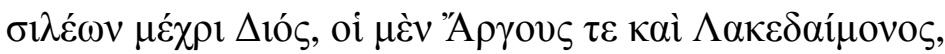

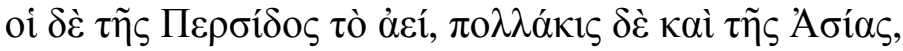

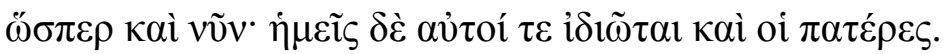

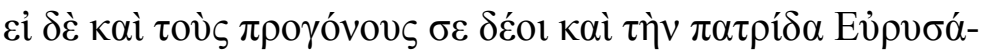

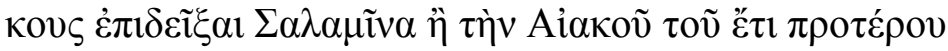

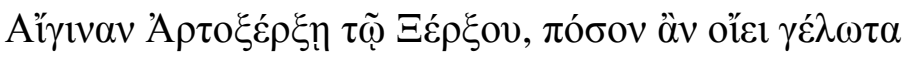

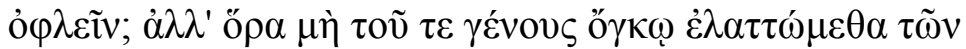

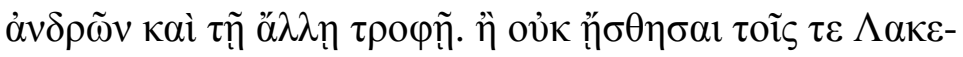

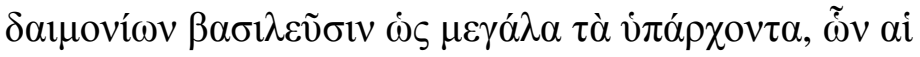

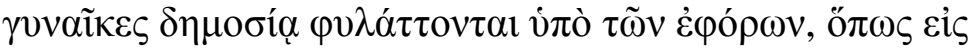

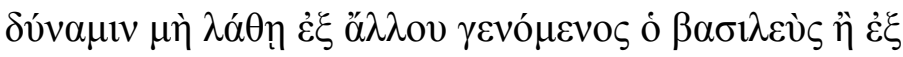

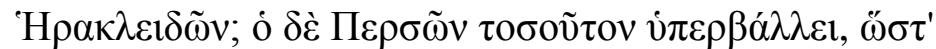

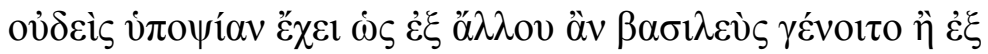

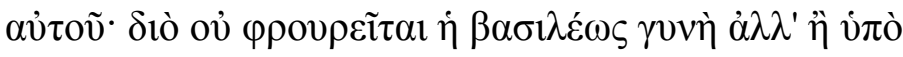

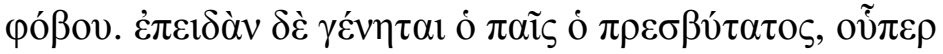

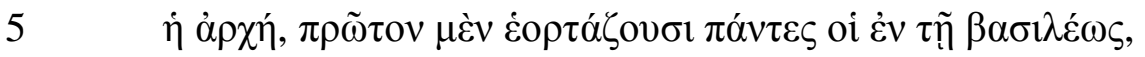

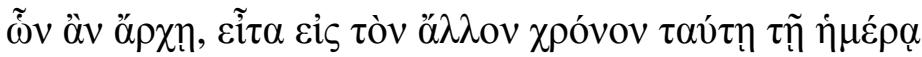

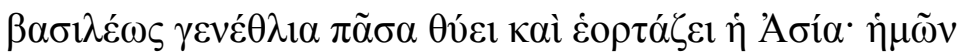

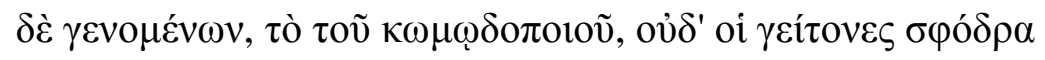

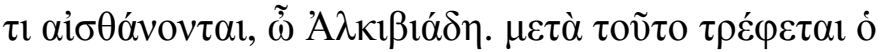

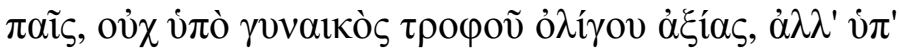

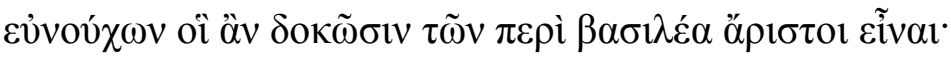

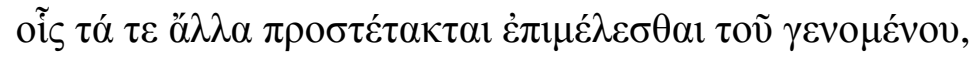

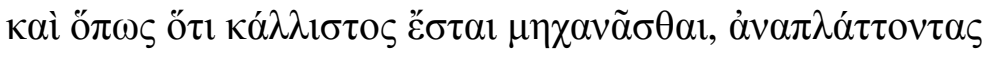

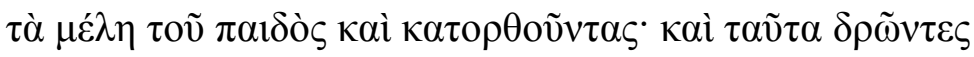


e a de Eurísaques, a Zeus.

[SÓC.] E também a minha, meu caro Alcibíades, remonta a Dédalo, e a de Dédalo, a Hefesto, filho de Zeus. Contudo, a origem da linhagem desses reis, a partir deles próprios, remonta a Zeus; os reis de Argos e da Lacedemônia, de um lado, os da Pérsia sempre reinantes, de outro, e muitas vezes, também os da Ásia, como agora. Mas quanto a nós, somos pessoas comuns, como o eram nossos pais. Se fosse preciso que você expusesse a Artaxerxes, filho de Xerxes, os seus ancestrais e a terra-natal de Eurísaques, Salamina, ou a de seu ancestral Éaco, Egina, o quanto você julga que se exporia ao ridículo? Mas veja se não somos inferiores a esses homens tanto em dignidade de linhagem quanto em educação. Ou você não percebeu quão magníficos são os privilégios dos reis lacedemônios, cujas mulheres são postas sob a custódia dos éforos a expensas públicas, de modo a garantir que o rei não nasça de qualquer estirpe a não ser a dos Heraclidas? O rei dos persas, por sua vez, é tão distinto que ninguém desconfia de que o rei nasceria de outra estirpe que não de sua própria. Por esse motivo, a mulher do rei não é vigiada senão pelo medo. Quando nasce o filho mais velho, a quem cabe o poder, primeiramente todos os subordinados do rei no palácio festejam, depois, a cada ano, a Ásia inteira celebra o dia do nascimento do rei, com sacrifícios e banquetes. Por outro lado, quando nós nascemos, como diz o poeta cômico, mesmo os vizinhos mal o percebem, ó Alcibíades. Depois disso, o menino é criado não por uma ama de pouco mérito, mas pelos eunucos mais reputados no séquito do rei. Eles são encarregados de zelar pelo menino e, em especial, de cuidar para que ele seja o mais belo, modelando e endireitando os seus membros. Aqueles que cuidam disso 


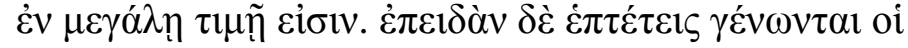

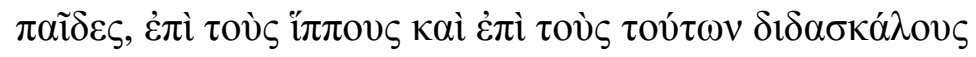

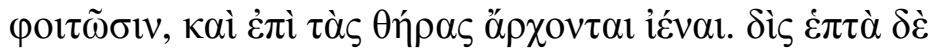

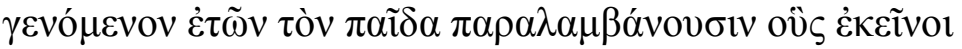

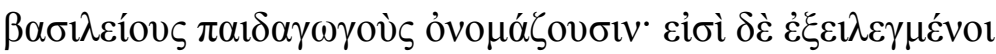

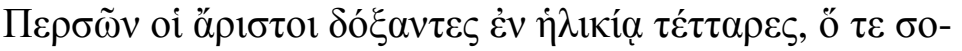

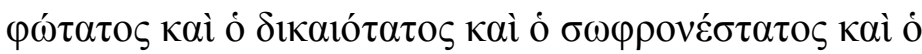

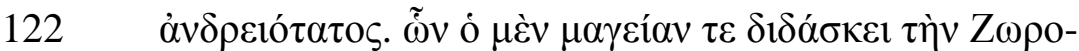

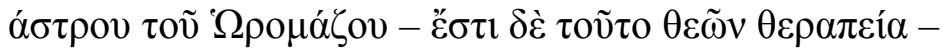

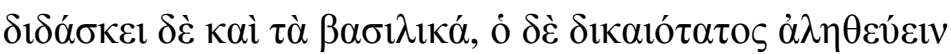

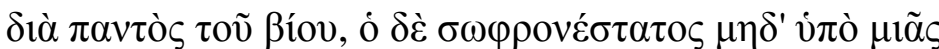

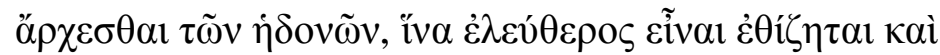

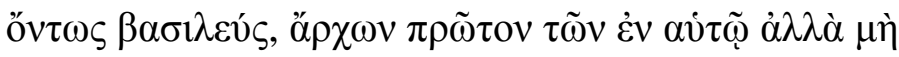

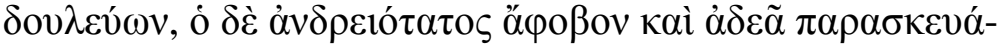

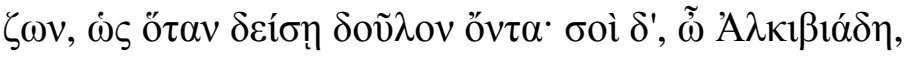

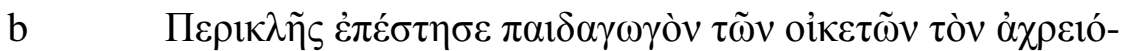

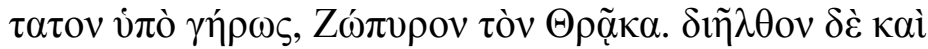

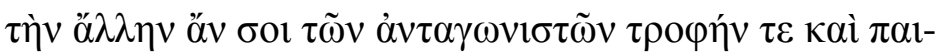

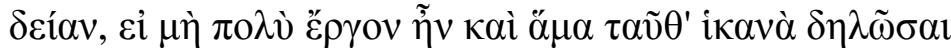

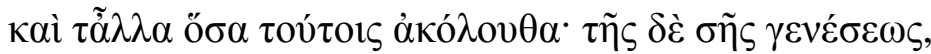

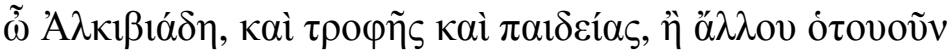

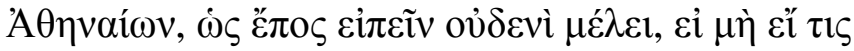

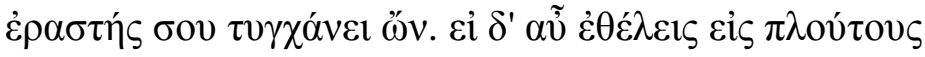

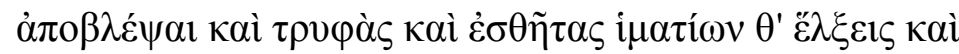
$\mu$

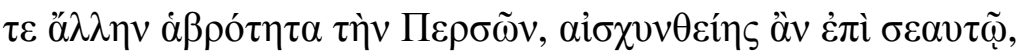

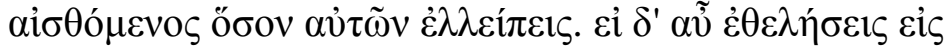

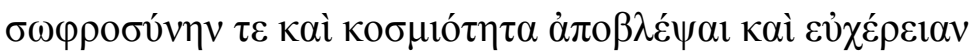

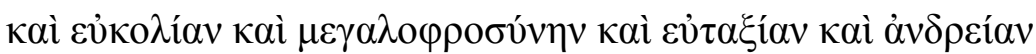


gozam de grande estima. Ao completarem sete anos de idade, os meninos e passam a frequentar lições de equitação junto aos professores e começam a caçar. Aos catorze anos de idade, o menino começa a tomar lições com quem eles chamam de preceptores reais. Os escolhidos são os quatro considerados os melhores homens entre os persas, no auge da maturidade: o mais sábio, o mais justo, o mais temperante e o mais corajoso. $\mathrm{O}$ primeiro deles é quem lhe ensina a magia de Zoroastro, filho de Horomázes - isto é, o culto aos deuses - e também lhe ensina o que é próprio dos reis; o mais justo, por sua vez, ensina-o a ser verdadeiro por toda a sua vida; o mais temperante, a nunca ser dominado pelos prazeres, para que se habitue a ser livre e rei de verdade, dominando, primeiramente, a si mesmo e não se escravizando; e, por último, o mais corajoso, ensina-o a tornar-se um homem sem medo e inquietação, para que só tema tornar-se escravo. Mas para você, ó Alcibíades, Péricles escolheu como preceptor o escravo doméstico mais inútil por causa de sua velhice, Zópiro, o Trácio. Eu poderia lhe expor também o restante da criação e da educação de seus adversários, se não fosse muito oneroso; todavia, o que já lhe expus é suficiente para mostrar o que se segue disso. Com a sua linhagem, criação e educação, ó Alcibíades, ou a de qualquer outro ateniense, ninguém se preocupa, por assim dizer, a não ser no caso de alguém ser o seu amante. Mas se você deseja, por um lado, voltar o seu olhar para as riquezas, o luxo, as vestimentas, os mantos longos, os unguentos de mirra, as comitivas com muitos servos, além das demais opulências dos persas, você teria vergonha de si mesmo ao perceber o quanto é inferior a eles. Se você deseja, por outro lado, voltar o seu olhar para a temperança, o comedimento, a fortaleza, o bom humor, a magnificência, a disciplina, a coragem, 


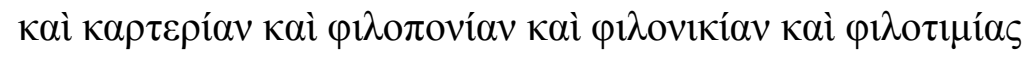

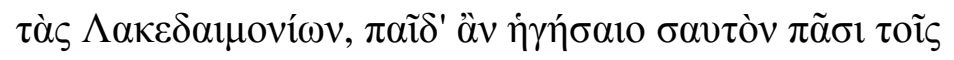

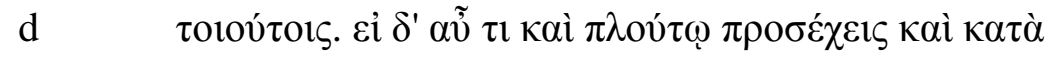

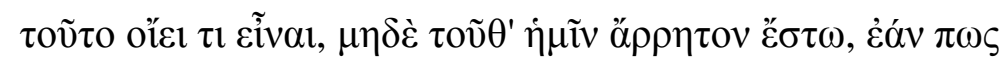

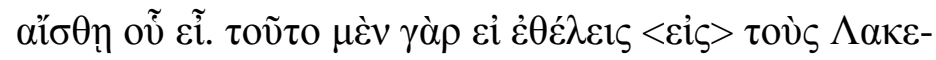

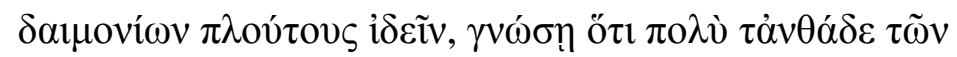

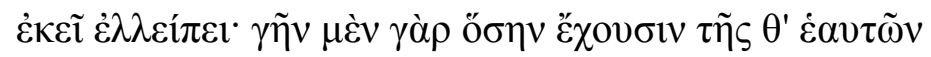

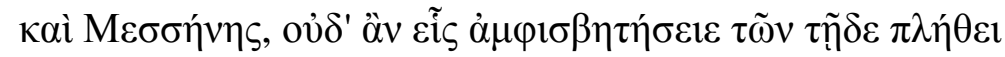

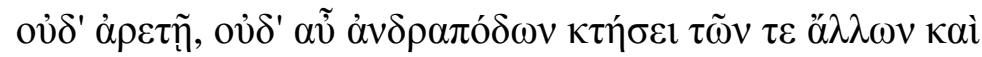

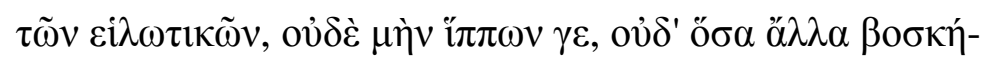

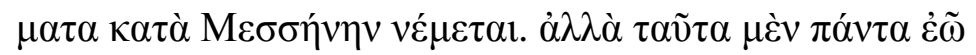

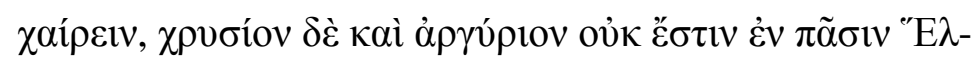

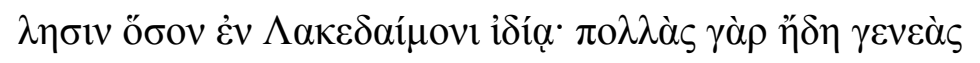

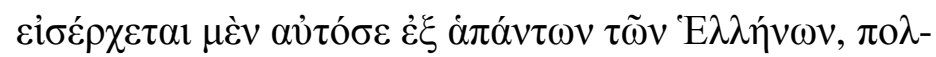

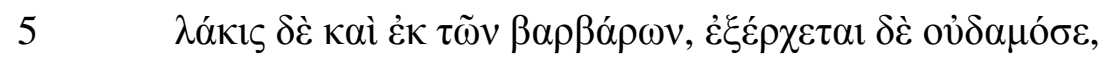

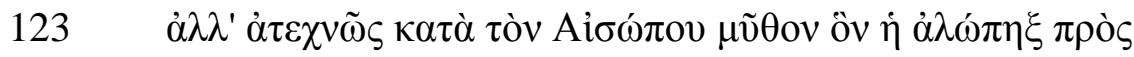

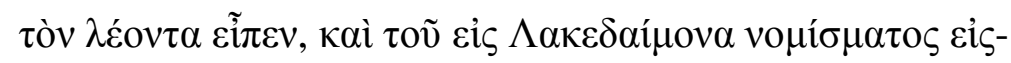

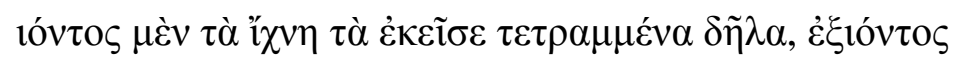

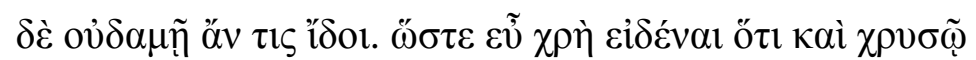

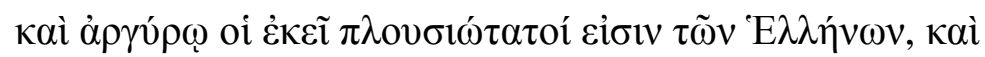
$\alpha$

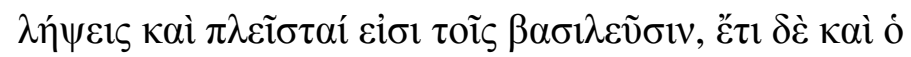

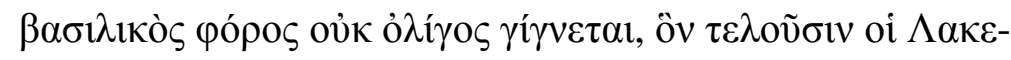

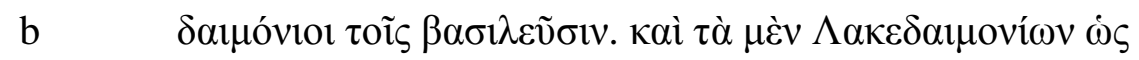

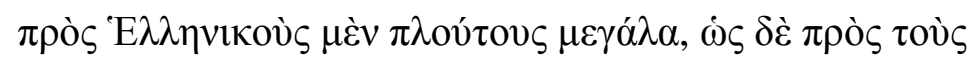

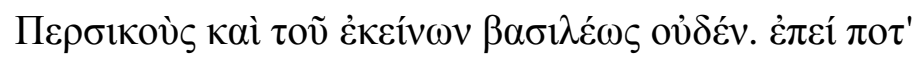
$\dot{\varepsilon} \gamma \omega \grave{\eta ்} \kappa o v \sigma \alpha \dot{\alpha} v \delta \rho \grave{\varsigma} \varsigma \dot{\alpha} \xi 10 \pi i ́ \sigma \tau o v \tau \tilde{\omega} v \dot{\alpha} v \alpha \beta \varepsilon \beta \eta \kappa o ́ \tau \omega \nu \pi \alpha \rho \grave{\alpha}$

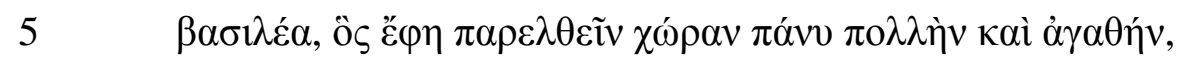

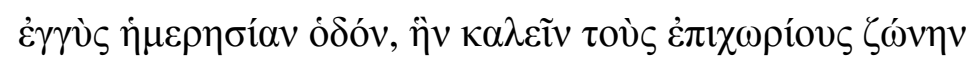


a perseverança, o gosto pelo trabalho, pela vitória e pelas honrarias dos lacedemônios, você consideraria a si mesmo uma criança em todos esses aspectos. Contudo, se você ainda se preocupa, de algum modo, com a d riqueza, julgando-se importante por isso, não deixemos de discutir sobre o assunto, para que você perceba a sua condição. Nesse tocante, se você deseja voltar o seu olhar para as riquezas dos lacedemônios, você reconhecerá que as nossas são muito inferiores às deles. Pois eles possuem tanto as próprias terras quanto as de Messênia, e ninguém de nós poderia disputar com eles sobre a extensão ou a qualidade das terras, nem sobre a posse de escravos e, especialmente, de hilotas, tampouco sobre a posse de cavalos e de quaisquer outros rebanhos que são criados na Messênia. Mas, deixando tudo isso de lado, em toda a Hélade não há tanto ouro e prata quanto há na própria Lacedemônia. Pois, há muitas gerações, eles vêm sendo acumulados ali provindo de toda a Hélade, e, muitas vezes, inclusive dos povos bárbaros; porém, nunca são expedidos para outro lugar. É praticamente o que acontece na fábula de Esopo, em que uma raposa diz ao leão: quando o dinheiro entra na Lacedemônia, os vestígios de sua entrada são evidentes, mas quando dali ele sai, ninguém conseguiria vê-lo sair. Dessa maneira, você deve saber com segurança que eles são os mais ricos dentre os helenos em ouro e prata, e que, entre eles, o mais rico é o rei. Pois os reis possuem os maiores e melhores rendimentos, e, além disso, ainda há a taxa do tributo real que os lacedemônios pagam aos reis, a qual não é pequena. As riquezas dos lacedemônios são magníficas diante das riquezas dos helenos, ao passo que, diante das dos persas e de seu rei, são insignificantes. Certa vez ouvi de um homem digno de fé, o qual havia visitado o rei, que ele atravessara, numa jornada, uma terra muito vasta e bela, que os nativos chamavam de 'cinta 


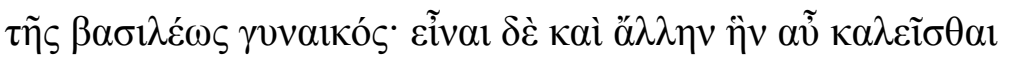

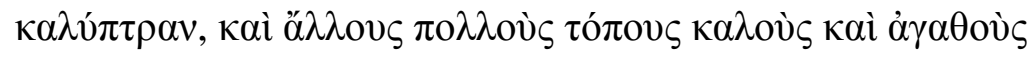

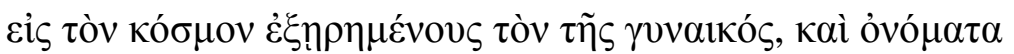

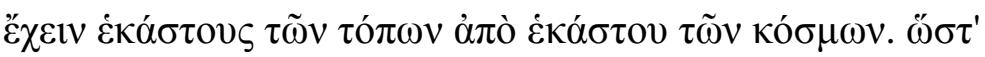

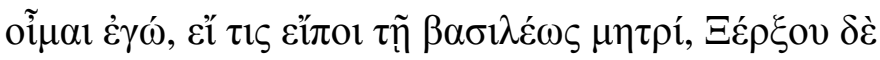

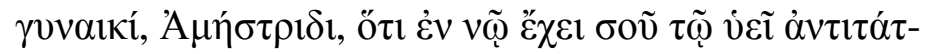

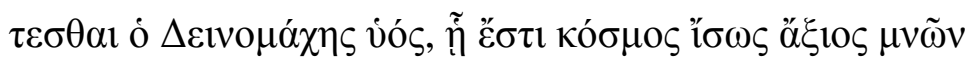

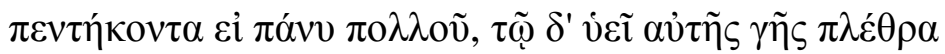

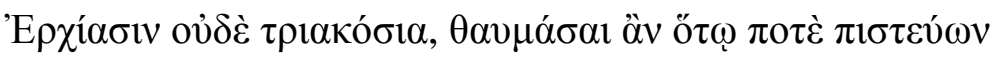

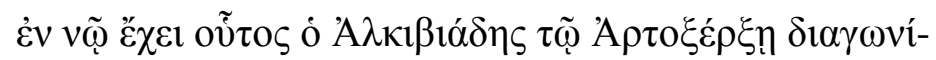

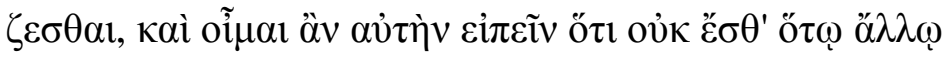

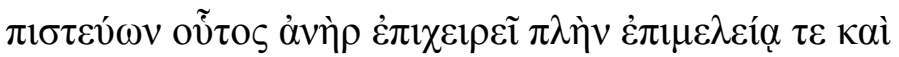

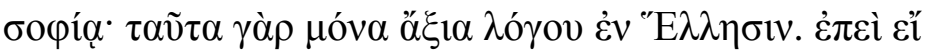

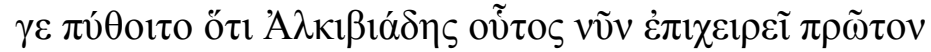

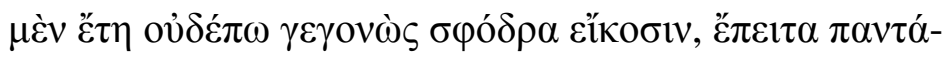

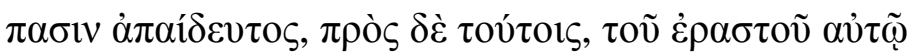

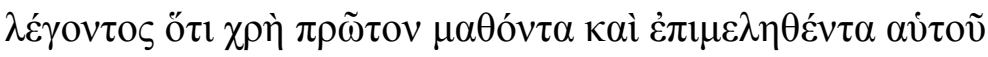

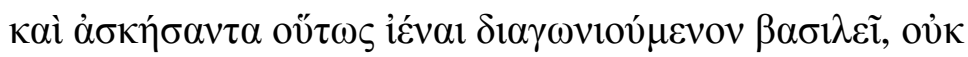

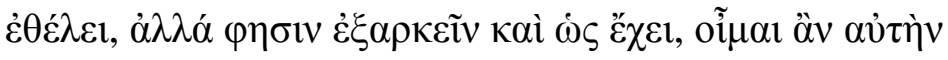

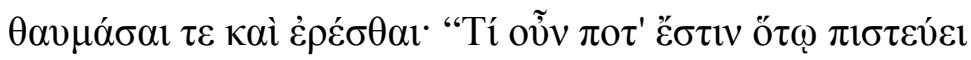

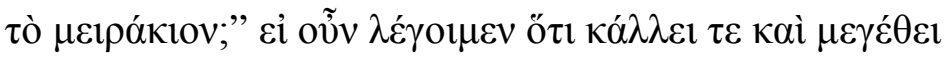

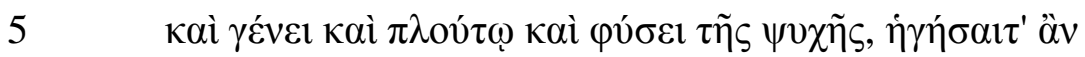

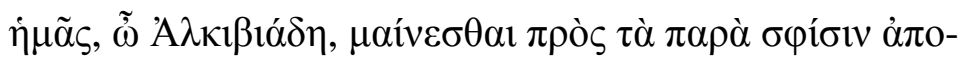

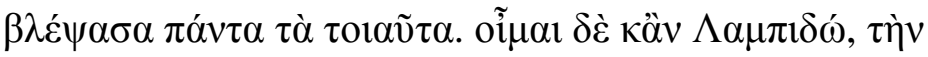

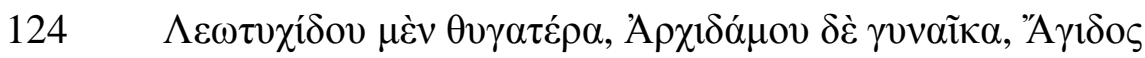

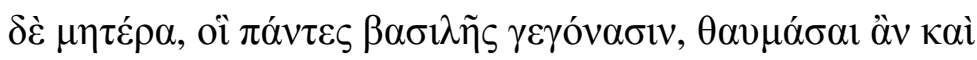

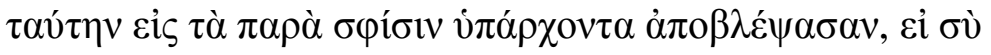

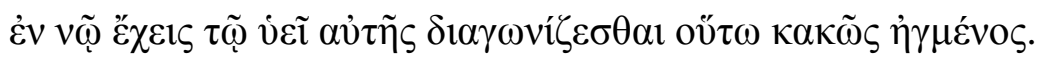

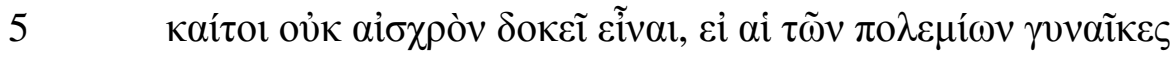


da mulher do rei'. E que havia também outra chamada de 'véu', e tantos

outros belos e nobres lugares dedicados ao adorno da mulher, nomeados a partir de cada um deles. Segundo penso, se alguém dissesse a Améstride, mãe do rei e esposa de Xerxes, que Alcibíades, o filho de Dinômaca, pretendia competir com seu filho - Dinômaca, cujos adornos talvez valham cinquenta minas, se muito, e Alcibíades, cujas terras em Érquia não chegam a equivaler a trezentos pletros - ela se perguntaria surpresa em que esse Alcibíades se fia a ponto de pretender rivalizar com Artaxerxes. E penso que ela diria que não há nada em que esse homem possa se fiar a não ser em cuidado e em sabedoria para tal investida, pois somente isso é digno de consideração entre os helenos. Contudo, se ela descobrisse que esse Alcibíades tem essa pretensão, em primeiro lugar, aos vinte anos de idade que ainda nem atingiu propriamente, e, em segundo lugar, sem ter qualquer instrução; e que, além disso, ele recusa ouvir seu amante quando lhe diz que é preciso antes se dedicar aos estudos e cuidar de si mesmo para então rivalizar com o rei, contra-argumentando que aquilo que ele tem já lhe é suficiente; nessas condições, penso que ela, tomada de espanto, perguntaria: “O que resta, então, para o jovem se fiar?” Se respondêssemos, então, que restam a beleza, a estatura, a linhagem, a riqueza e a natureza da alma, ó Alcibíades, ela julgaria que nós estamos delirando, ao compará-los com os do seu povo. Penso que Lampido igualmente, a filha de Leotiquides, mulher de Arquidamo e mãe de Ágis - todos eles foram reis - seria tomada de espanto ao compará-los com os de seu povo, se você pretendesse rivalizar com o seu filho, estando nesta condição deplorável. Com efeito, não parece vergonhoso que as mulheres dos nossos inimigos 


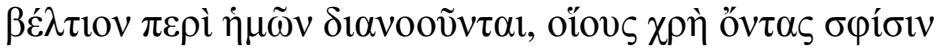

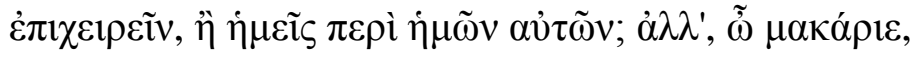

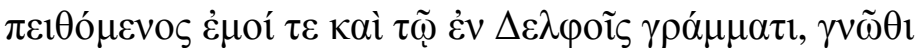

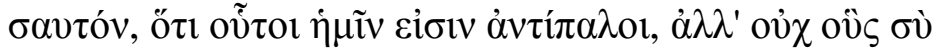

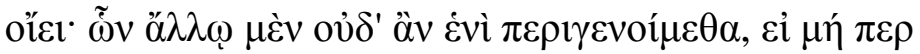

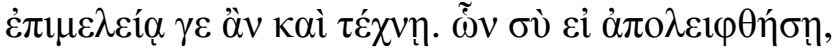

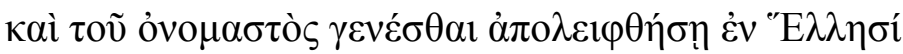

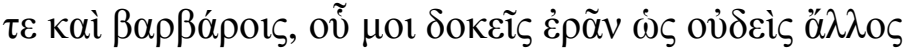

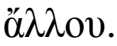

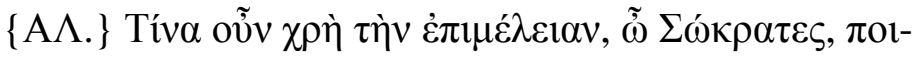

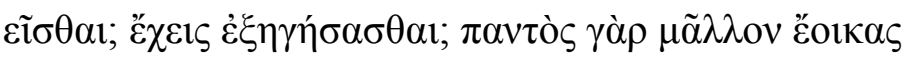

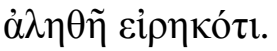

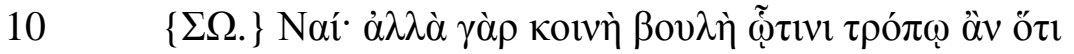

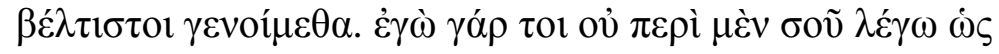

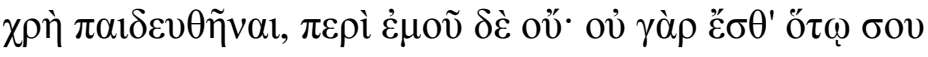
$\delta 1 \alpha \varphi \varepsilon ́ \rho \omega \pi \lambda \eta \dot{v} \gamma^{\prime} \dot{\varepsilon} v i ́$.

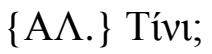

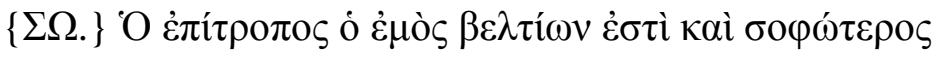

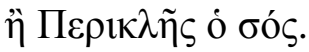

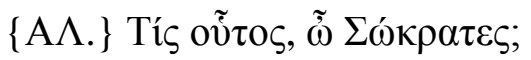

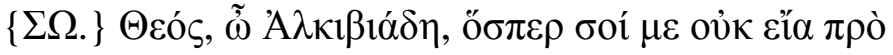

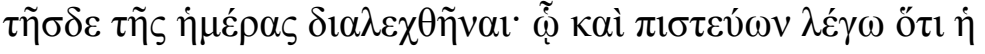

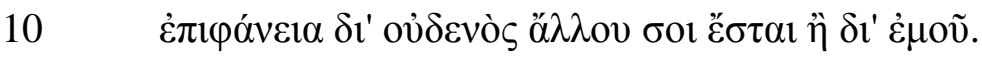

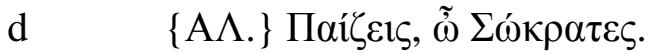

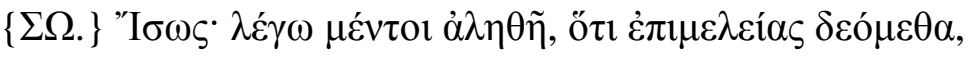

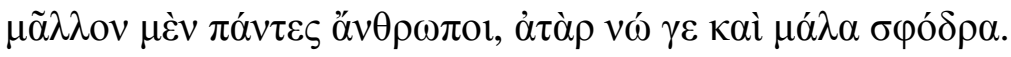

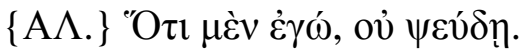

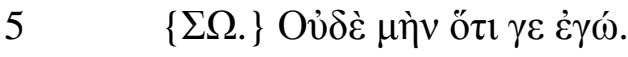

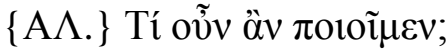


reflitam melhor do que nós mesmos sobre as qualidades que devemos ter para então investirmos contra eles? Mas, ó bem-aventurado, obedecendo a mim e à inscrição em Delfos, conheça a si mesmo! Pois são esses os nossos adversários, e não aqueles que você considerava. Não poderíamos superálos em outra coisa senão em cuidado e em arte. Se você negligenciar isso, negligenciará também o seu futuro renome entre os helenos e os bárbaros, o que você me parece almejar como nenhum outro homem almeja alguma outra coisa.

[ALC.] É preciso colocar em prática, então, que tipo de cuidado, ó Sócrates? Pode explicar em maiores detalhes? Pois, mais do que todos, você parece ter dito a verdade.

[SÓC.] Sim, posso. Todavia, é preciso uma deliberação conjunta sobre o modo pelo qual poderíamos nos tornar melhores. Pois certamente estou me referindo tanto a você quanto a mim, quando digo que é preciso de instrução: pois não me distingo de você em nada, a não ser em uma única coisa.

[ALC.] Em quê?

[SÓC.] O meu tutor é melhor e mais sábio do que Péricles, o seu tutor.

[ALC.] E quem é ele, Sócrates?

[SÓC.] Um deus, ó Alcibíades, aquele que me impedia de dialogar com você até o dia de hoje. E, confiante nele, eu afirmo que a sua manifestação não acontecerá a você senão através de mim.

[ALC.] Você está brincando, ó Sócrates.

[SÓC.] Talvez. Contudo, estou falando a verdade: que necessitamos de cuidado, assim como todos os homens o necessitam; nós dois, contudo, em especial.

[ALC.] A respeito de mim, você não está mentindo.

[SÓC.] E nem a respeito de mim.

[ALC.] O que, então, deveríamos fazer? 


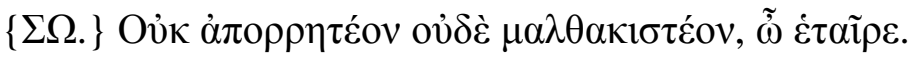

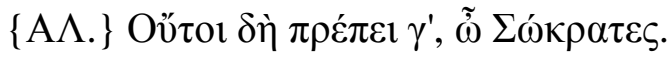

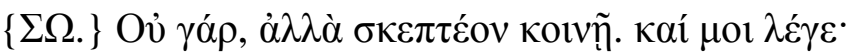

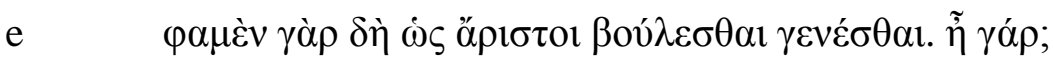

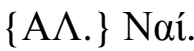

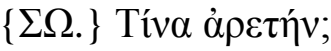

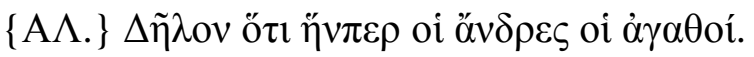

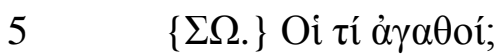

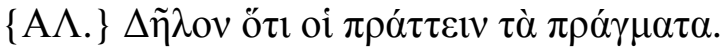

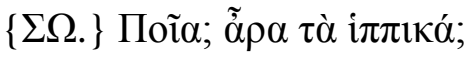

$\{\mathrm{A} \Lambda$.$\} Ov̉ \delta \tilde{\eta} \tau \alpha$.

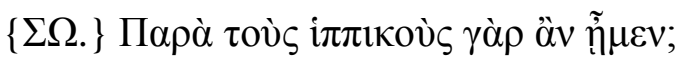

$10 \quad\{$ A $\Lambda$.$\} Naí.$

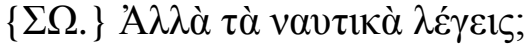

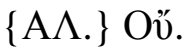

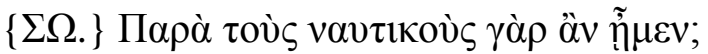

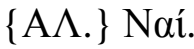

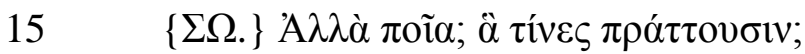

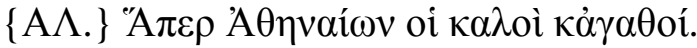

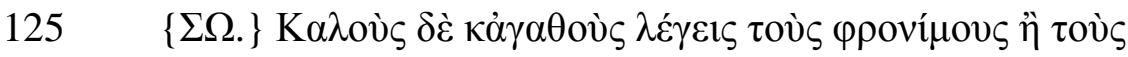

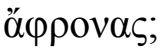

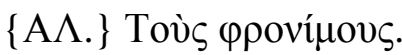

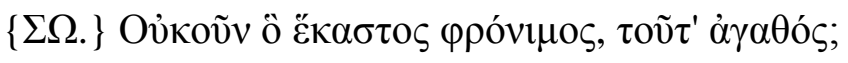

$5 \quad\{$ A $\Lambda$.$\} Naí.$

$\{\Sigma \Omega$.$\} "O \delta \dot{\varepsilon}$ ä $\varphi \rho \omega v, \pi 0 v \eta \rho o ́ \zeta ;$

$\{\mathrm{A} \Lambda.\} \Pi \tilde{\omega} \varsigma \gamma \grave{\alpha} \rho$ oü;

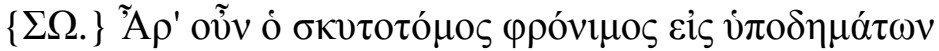

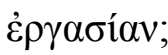

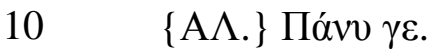


[SÓC.] Não devemos desistir nem fraquejar, meu amigo!

[ALC.] Certamente não nos convém, ó Sócrates.

[SÓC.] De fato, não, mas devemos investigar juntos. Então, diga-me: afirmamos que queremos nos tornar melhores. Ou não?

[ALC.] É.

[SÓC.] Em qual virtude?

[ALC.] É evidente que naquela em relação a qual os homens são bons.

[SÓC.] Bons em quê?

[ALC.] É evidente que em praticar ações.

[SÓC.] De qual tipo? Por acaso você se refere à equitação?

[ALC.] Certamente não.

[SÓC.] Pois iríamos à procura dos cavaleiros, não é?

[ALC.] Sim.

[SÓC.] Então você se refere à navegação?

[ALC.] Não.

[SÓC.] Pois assim iríamos à procura dos marinheiros, não é?

[ALC.] Sim.

[SÓC.] Mas quais ações, então? Quais homens as praticam?

[ALC.] Dentre os atenienses, os homens excelentes.

[SÓC.] Por excelentes, você se refere aos homens inteligentes, ou aos ignorantes?

[ALC.] Aos inteligentes.

[SÓC.] Então, cada homem não é bom naquilo em que é inteligente?

[ALC.] Sim.

[SÓC.] E mau, naquilo em que é ignorante?

[ALC.] Como não o seria?

[SÓC.] Acaso, então, o sapateiro não é inteligente na manufatura de calçados?

[ALC.] Certamente. 


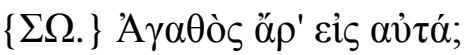

$\{\mathrm{A} \Lambda$.$\} 'A \gamma \alpha \theta$ ós.

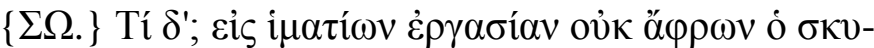

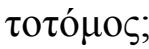

$15 \quad\{$ A $\Lambda$.$\} Naí.$

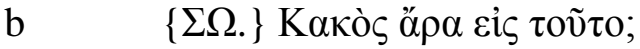

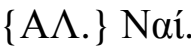

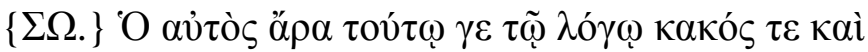

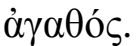

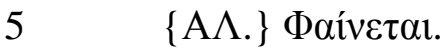

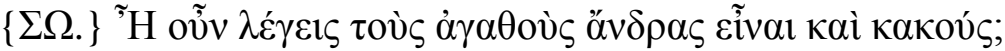

$\{\mathrm{A} \Lambda$.$\} O ̉̇ \delta \tilde{\eta} \tau \alpha$.

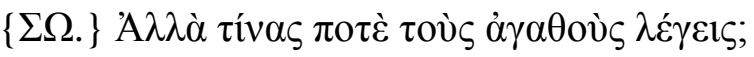

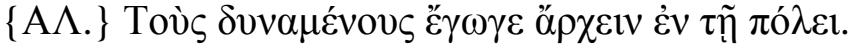

$10 \quad\{\Sigma \Omega$.$\} Oủ \delta \eta ் \pi 0 v$ ĭ $\pi \pi \omega \nu \gamma \varepsilon$;

$\{\mathrm{A} \Lambda$.$\} Ov̉ \delta \tilde{\eta} \tau \alpha$.

$\{\Sigma \Omega.\}{ }^{\prime} A \lambda \lambda^{\prime} \alpha \dot{\alpha} v \theta \rho \omega ́ \pi \omega v$;

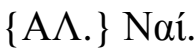

$\{\Sigma \Omega.\}{ }^{\tilde{A}} \mathrm{\rho} \rho \alpha \kappa \alpha \mu \nu \operatorname{vo\tau }_{\tau} \omega v$;

$15 \quad\{$ A $\Lambda$.$\} Ov้.$

$\{\Sigma \Omega$.$\} A \lambda \lambda \lambda \grave{\alpha} \pi \lambda \varepsilon \operatorname{có}_{\tau} \tau \omega v$;

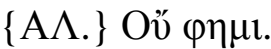

$\{\Sigma \Omega$.$\} 'A \lambda \lambda \alpha \grave{\alpha} \theta \varepsilon \rho 1 \zeta o ́ v \tau \omega v$;

$\{\mathrm{A} \Lambda$.$\} Ov́.$

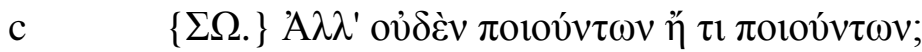

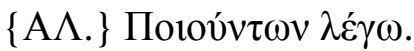

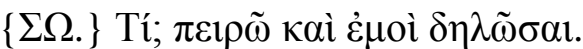

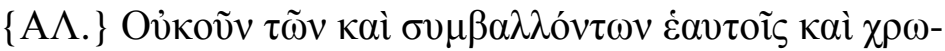

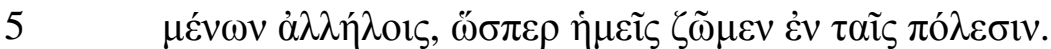


[SÓC.] Portanto, também bom nisso?

[ALC.] Sim.

[SÓC.] E então? O sapateiro não é ignorante na manufatura de vestimentas?

[ALC.] Sim.

[SÓC.] E mau, por conseguinte, em relação a isso?

[ALC.] Sim.

[SÓC.] Portanto, de acordo com o presente argumento, o mesmo homem é mau e bom.

[ALC.] É claro.

[SÓC.] E então, você diz que os homens bons são também maus?

[ALC.] É claro que não.

[SÓC.] A quais homens bons você se refere, afinal?

[ALC.] Refiro-me àqueles que são capazes de comandar a cidade.

[SÓC.] E certamente não comandam cavalos, não é?

[ALC.] É certo que não.

[SÓC.] Mas homens?

[ALC.] Sim.

[SÓC.] Acaso quando estão doentes?

[ALC.] Não.

[SÓC.] Mas quando estão navegando?

[ALC.] Também não.

[SÓC.] Quando estão fazendo a colheita?

[ALC.] Não.

[SÓC.] Mas quando não estão fazendo nada, ou quando estão fazendo c alguma coisa?

[ALC.] Quando estão fazendo alguma coisa, afirmo eu.

[SÓC.] Fazendo o quê? Esforce-se para me mostrar!

[ALC.] Bem, quando eles se relacionam e se servem uns dos outros, assim como nós fazemos vivendo nas cidades. 


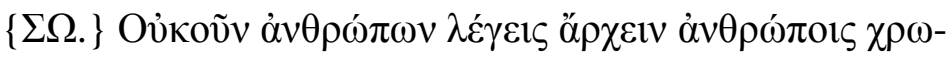
$\mu \varepsilon ́ v \omega v$

$\{$ A $\Lambda$.$\} Naí.$

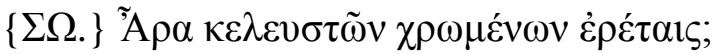

$10 \quad\{\mathrm{~A} \Lambda$.$\} Ov̉ \delta \tilde{\eta} \tau \alpha$.

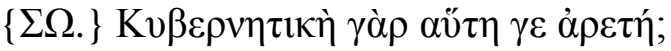

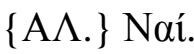

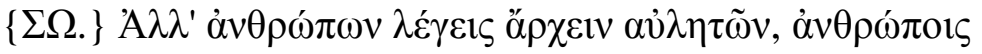

d

$\{\mathrm{A} \Lambda$.$\} Ở \delta \tilde{\eta} \tau \alpha$.

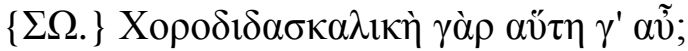

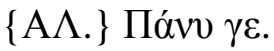

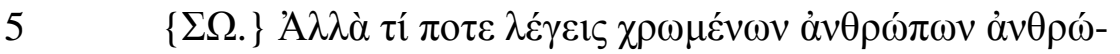

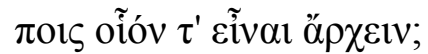

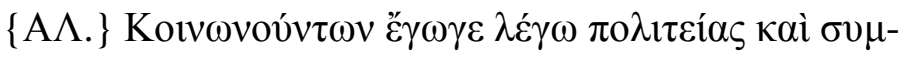

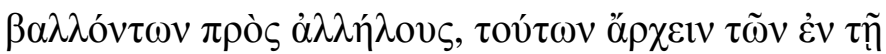
$\pi$ ó $\lambda \varepsilon 1$.

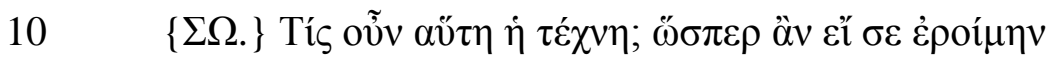

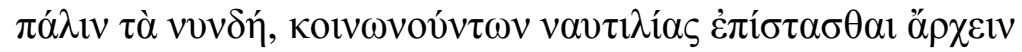

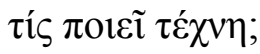

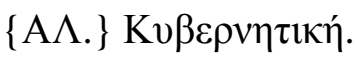

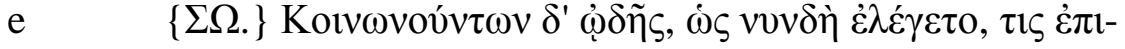

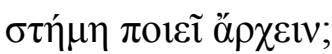

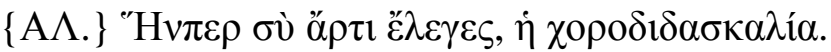

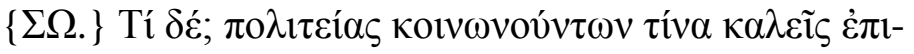

$5 \quad \sigma \tau \eta \dot{\mu \eta} v$

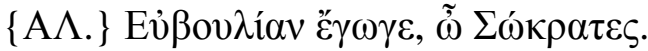

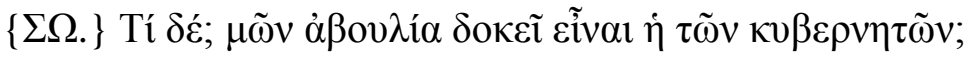

$\{\mathrm{A} \Lambda$.$\} O \delta \tilde{\eta} \tau \alpha$. 
[SÓC.] Então, você se refere ao comando dos homens que se servem de outros homens?

[ALC.] Sim.

[SÓC.] Acaso você se refere ao comando dos contramestres que se servem dos remadores?

[ALC.] Certamente não.

[SÓC.] Pois essa é a virtude da navegação, não é?

[ALC.] Sim.

[SÓC.] Mas você se refere ao comando dos auletas, os quais regem os cantores e se servem dos coreutas?

[ALC.] Certamente não.

[SÓC.] Pois essa é, por sua vez, a virtude do instrutor de coro, não é?

[ALC.] Certamente.

[SÓC.] Mas o que você quer dizer com ser capaz de comandar homens que se servem de homens?

[ALC.] Estou me referindo ao comando, na cidade, daqueles que compartilham da cidadania e se relacionam entre si.

[SÓC.] E qual seria essa arte? Como se eu lhe perguntasse novamente o que lhe perguntei há pouco, qual é a arte que torna alguém apto a comandar aqueles que participam da navegação?

[ALC.] A arte náutica.

[SÓC.] E, como há pouco foi dito, qual é o conhecimento que torna alguém apto a comandar os que participam do canto?

[ALC.] O que há pouco você mencionou: a arte da instrução do coro.

[SÓC.] E então? Como você denomina o conhecimento que torna alguém apto a comandar os que compartilham da cidadania?

[ALC.] Eu o chamo de bom conselho, ó Sócrates.

[SÓC.] E então? Porventura parece consistir em ausência de conselho o conhecimento dos capitães?

[ALC.] Certamente não. 


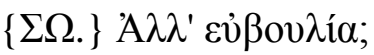

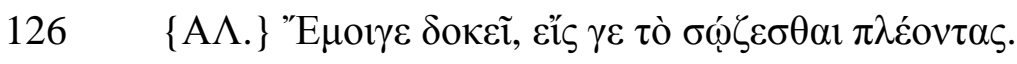

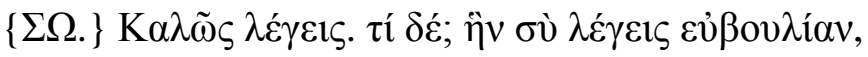

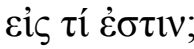

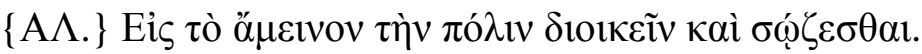

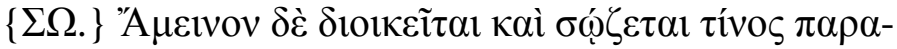

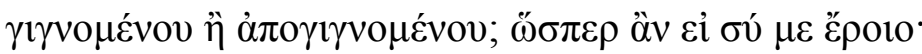

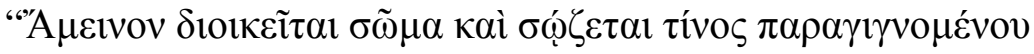

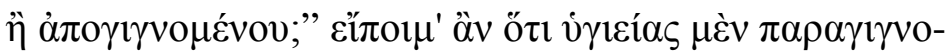

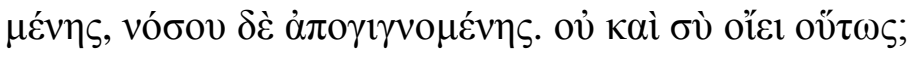

b $\quad\{$ A $\Lambda$.$\} Naí.$

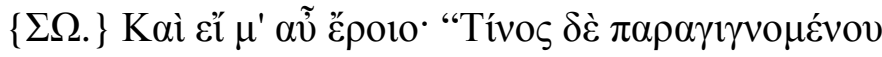

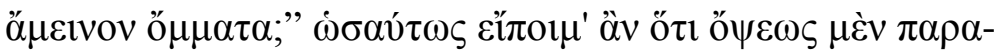

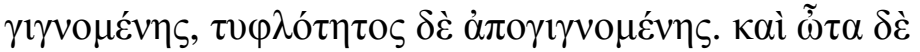

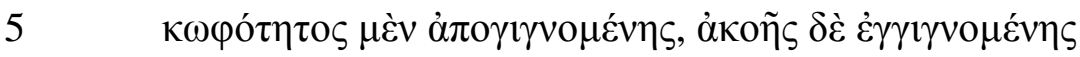

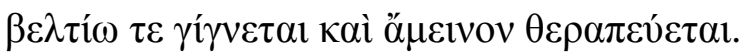

$\{\mathrm{A} \Lambda$.$\} 'O \rho \theta \tilde{\omega} \varsigma$.

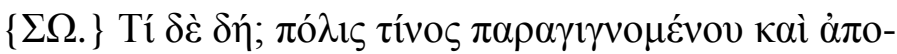

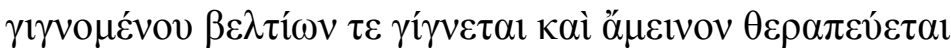

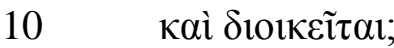

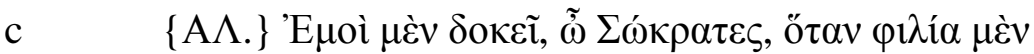

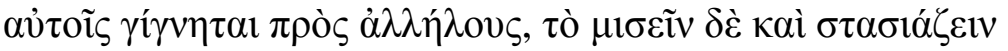

$\dot{\alpha} \pi \mathrm{o} \gamma \dot{\gamma} \gamma \nu \eta \tau \alpha 1$.

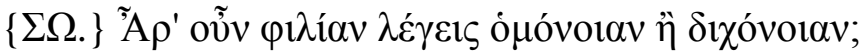

$\{\mathrm{A} \Lambda$.$\} O Oróvorav.$

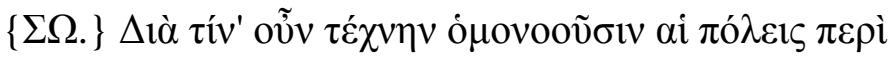

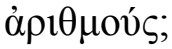

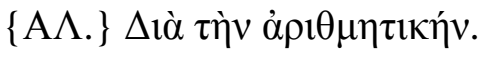

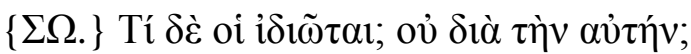


[SÓC.] Mas em bom conselho?

[ALC.] Parece-me que sim, e concernente ao salvamento da tripulação.

[SÓC.] Você fala com acerto. Mas então? Quando você se refere ao bom conselho, ele concerne a quê?

[ALC.] À melhor gestão e proteção da cidade.

[SÓC.] E ela é mais bem governada e protegida, estando presente ou ausente o quê? É como se você me perguntasse: "O corpo é mais bem governado e protegido, estando presente ou ausente o quê?", a que eu responderia que estando presente a saúde, e ausente a doença. Você não pensa assim também?

[ALC.] Sim.

[SÓC.] E se você ainda me perguntasse: “O que, estando presente, é melhor para os olhos?", eu responderia da mesma forma: estando presente a visão, e ausente a cegueira. Já os ouvidos, por sua vez, estão em melhor condição e são mais bem cuidados, quando a surdez está ausente, e a audição presente.

[ALC.] Correto.

[SÓC.] E então? A cidade, por sua vez, está em melhor condição e é mais bem cuidada e governada na presença e na ausência do quê?

[ALC.] A mim parece, ó Sócrates, quando esteja presente a amizade entre c os indivíduos, e estejam ausentes o ódio e a dissensão.

[SÓC.] Por acaso você se refere à amizade como concórdia, ou como discórdia?

[ALC.] Como concórdia.

[SÓC.] E através de qual arte as cidades entram em acordo sobre o que concerne aos números?

[ALC.] Através da aritmética.

[SÓC.] E quanto aos indivíduos particulares? Não é também através dela? 
\{A^.\} Naí.

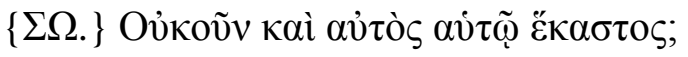

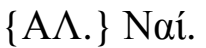

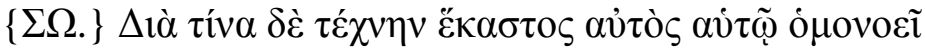

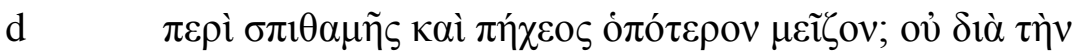

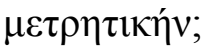

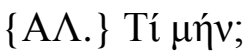

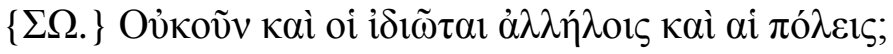

5

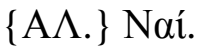

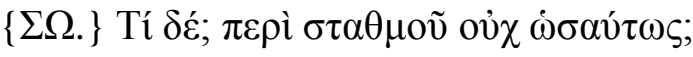

$\{\mathrm{A} \Lambda.\} \Phi \eta \mu \mathrm{i}$.

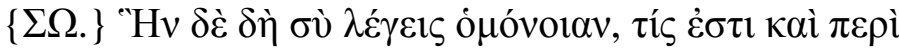

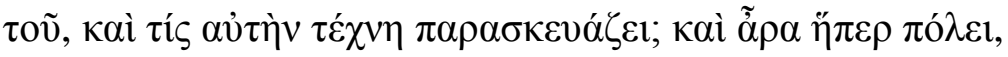

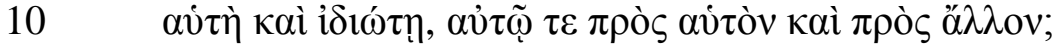

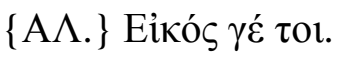

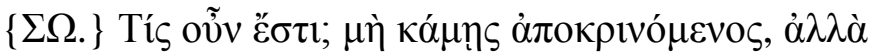

e $\quad \pi \rho \circ \theta v \mu о \tilde{v} \varepsilon i \pi \varepsilon \varepsilon \tilde{v}$.

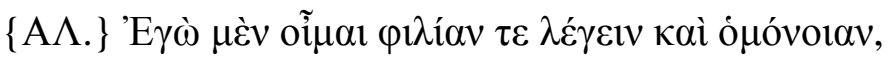

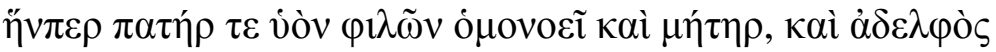

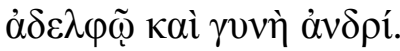

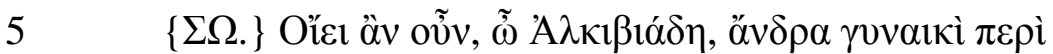

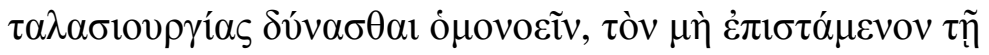
$\dot{\varepsilon} \pi 1 \sigma \tau \alpha \mu \varepsilon \dot{\varepsilon} \nu \eta$

$\{\mathrm{A} \Lambda$.$\} Ov̉ \delta \tilde{\eta} \tau \alpha$.

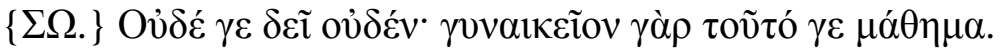

$10 \quad\{$ A $\Lambda$.$\} Naí.$

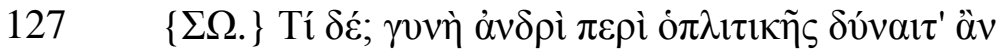

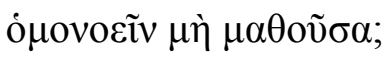

$\{\mathrm{A} \Lambda$.$\} O \delta \tilde{\eta} \tau \alpha$. 
[ALC.] Sim.

[SóC.] E o mesmo também não vale para cada um tomado individualmente?

[ALC.] Sim.

[SÓC.] E através de qual arte cada um entra em acordo consigo mesmo sobre qual medida é maior, o palmo ou o côvado? Não é através da arte da d mensuração?

[ALC.] Sim, e daí?

[SÓC.] E o mesmo também não vale tanto para os indivíduos particulares quanto para as cidades?

[ALC.] Sim.

[SÓC.] E então? Não sucede a mesma coisa à pesagem?

[ALC.] Sim, é claro.

[SÓC.] O que seria, então, essa concórdia a que você se referiu, e sobre o quê? Qual arte a provê? A arte que provê a cidade disso, porventura é a mesma que provê o indivíduo particular, seja na relação consigo próprio, seja na relação com os outros?

[ALC.] Parece que sim.

[SÓC.] Então o que é? Não hesite em responder, mas o faça com disposição!

[ALC.] Eu creio que se trata daquela amizade e concórdia, quando o pai e a mãe entram em acordo com o filho que amam, bem como o irmão com o irmão, e a esposa com o marido.

[SÓC.] Então você julga, ó Alcibíades, que seria possível ao homem entrar em acordo com sua esposa no que diz respeito ao trabalho com a lã, ou seja, alguém sem conhecimento entrar em acordo com alguém dotado de conhecimento?

[ALC.] Certamente não.

[SÓC.] E nem lhe é necessário, já que se trata de um ofício feminino.

[ALC.] Sim.

[SÓC.] E então? Uma mulher, por sua vez, poderia entrar em acordo com seu marido no que diz respeito à arte dos hoplitas, não a tendo aprendido?

[ALC.] Também não. 


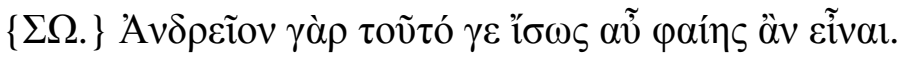

5

$\{\mathrm{A} \Lambda.\}{ }^{\prime} \mathrm{E} \gamma \omega \gamma \varepsilon$.

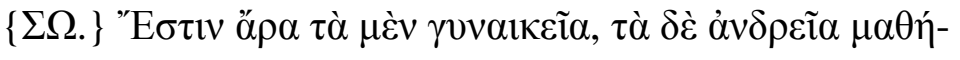

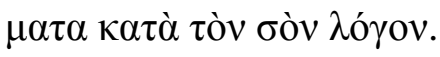

$\{\mathrm{A \Lambda .}\} \Pi \tilde{\omega} \varsigma \delta^{\prime}$ oü;

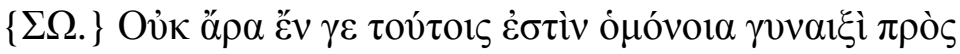

$10 \quad \alpha ́ v \delta \rho \alpha \varsigma$.

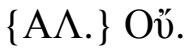

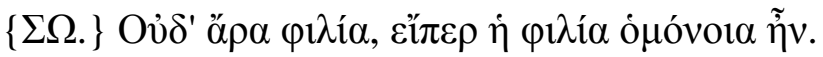

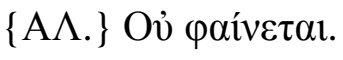

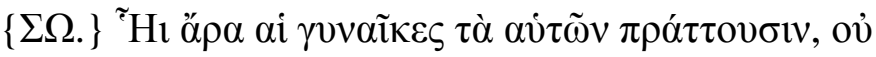

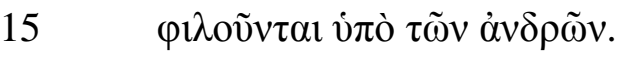

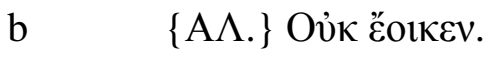

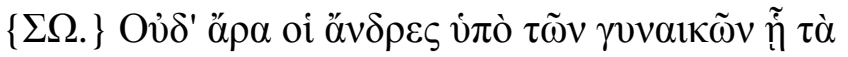

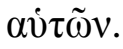

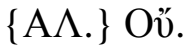

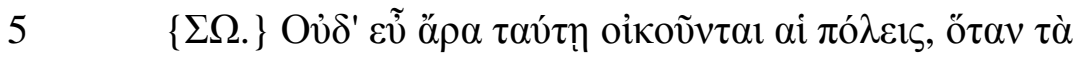

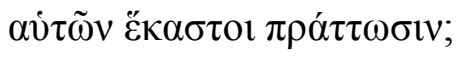

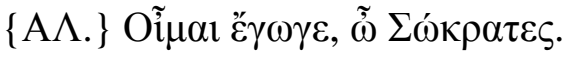

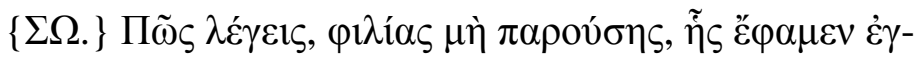

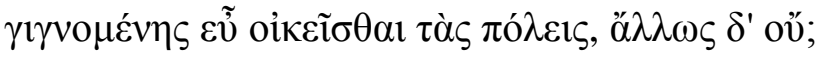

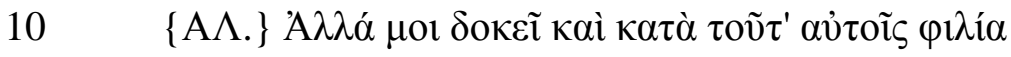

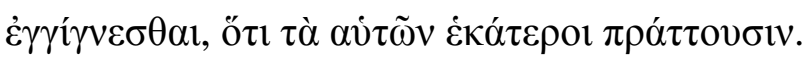

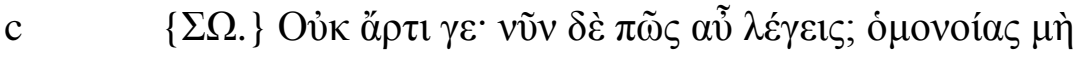

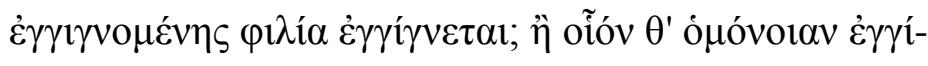

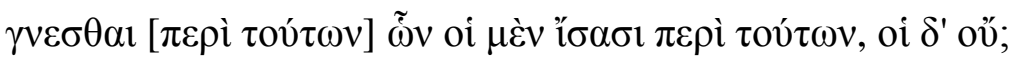

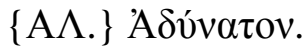

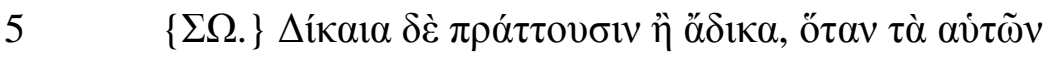

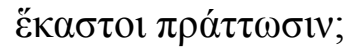


[SÓC.] Pois, mais uma vez, você poderia dizer que se trata de um ofício masculino.

[ALC.] De fato.

[SÓC.] Portanto, de acordo com o seu argumento, segue-se que há ofícios próprios das mulheres, e outros próprios dos homens.

[ALC.] E como não?

[SÓC.] E, nesses casos, não há, portanto, concórdia entre as mulheres e os homens.

[ALC.] Não há.

[SÓC.] E, por conseguinte, nem mesmo amizade, se a amizade era concórdia.

[ALC.] É claro que não.

[SÓC.] As mulheres, portanto, na medida em que praticam os seus próprios afazeres, não são amadas pelos homens.

[ALC.] É plausível que não.

[SÓC.] Tampouco os homens são amados pelas mulheres, na medida em que praticam os seus próprios afazeres.

[ALC.] Nem eles.

[SÓC.] Nem as cidades, portanto, são bem administradas, quando cada um exerce o seu próprio ofício.

[ALC.] Penso que elas são sim, ó Sócrates.

[SÓC.] Então, como você pode dizer que as cidades são bem geridas, se não há amizade, sendo que nós admitimos que elas assim o são quando a amizade está presente, e não de outra maneira?

[ALC.] Mas a mim parece que a amizade está presente por causa disto: porque cada um pratica o que lhe é próprio.

[SÓC.] Não lhe parecia há pouco. Mas, agora, o que você quer dizer, então? A amizade ocorre na ausência da concórdia? Ou é possível que a concórdia ocorra entre os que possuem um determinado conhecimento e os que não o possuem?

[ALC.] Não é possível.

[SÓC.] E quando exercem o que lhes é próprio, eles praticam o que é justo, ou o que é injusto? 


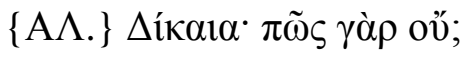

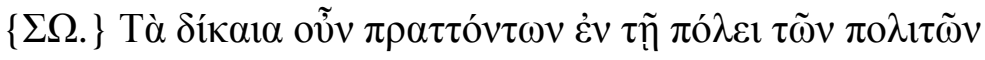

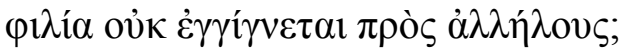

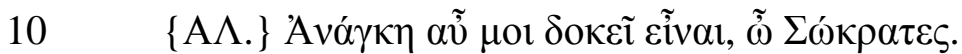

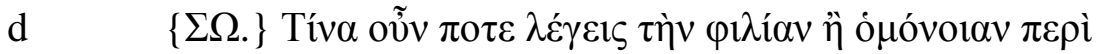

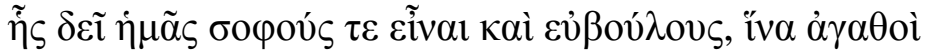

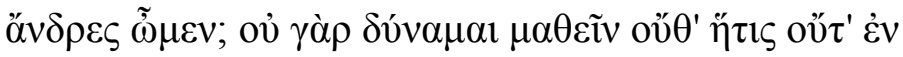

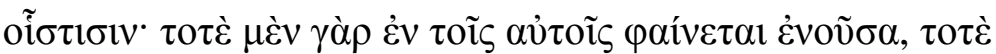

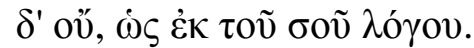

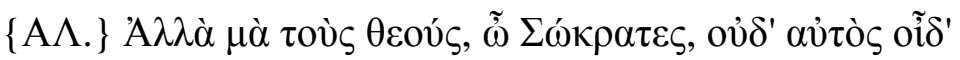

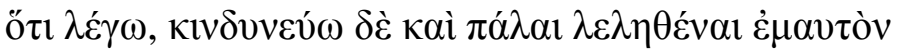
$\alpha$

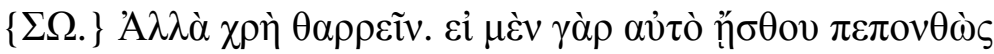

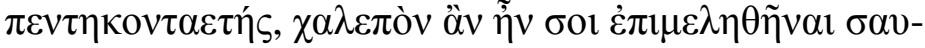

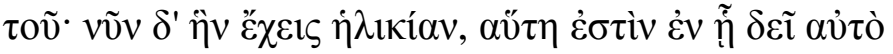
$\alpha i ் \theta \dot{\varepsilon} \sigma \theta \alpha 1$.

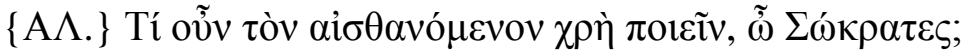

$5 \quad\{\Sigma \Omega$.$\} Ađ$

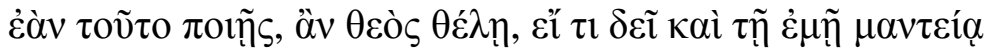

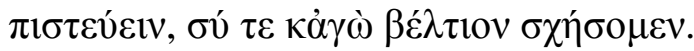

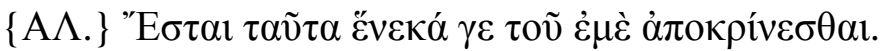

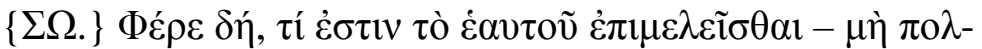

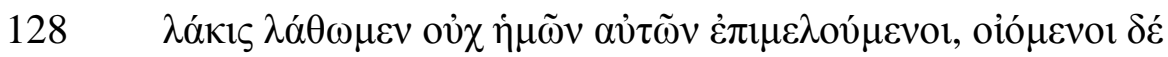

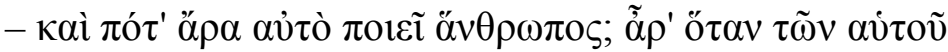

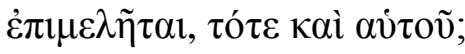

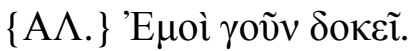

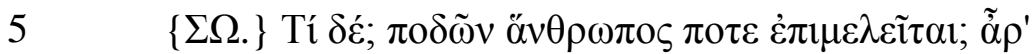

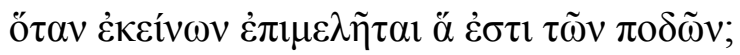

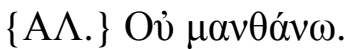


[ALC.] O que é justo; pois como não seria?

[SÓC.] Então, ao praticarem o que é justo na cidade, a amizade não está presente entre os cidadãos?

[ALC.] Parece-me ser forçoso que sim, ó Sócrates.

[SÓC.] Então, o que é isso que você chama de amizade ou concórdia a d respeito da qual nós devemos ser sábios e bons conselheiros, a fim de que nos tornemos bons homens? Pois ainda não pude compreender nem o que é, nem em quem se encontra. Pois, segundo o seu argumento, em alguns momentos ela parece estar presente em certos indivíduos, enquanto em outros momentos, não.

[ALC.] Mas pelos deuses, ó Sócrates, nem mesmo eu sei o que falo, e corro o risco de há muito tempo não ter percebido a condição lastimável em que me encontro.

[SÓC.] Mas você deve ter confiança. Pois se tivesse percebido isso apenas aos cinquenta anos de idade, cuidar de si mesmo seria penoso. Entretanto, a idade em que você se encontra agora é precisamente aquela propícia para percebê-lo.

[ALC.] O que, então, deve fazer quem percebe isso, ó Sócrates?

[SÓC.] Responder as perguntas, ó Alcibíades. E se assim você o fizer, se o deus desejar, e se você depositar alguma confiança na minha divinação, você e eu alcançaremos uma melhor condição.

[ALC.] Assim será no que depender de minhas respostas.

[SÓC.] Vamos lá, então! O que é o cuidado de si - eu temo que frequentemente não percebemos que não estamos cuidando de nós mesmos, mas apenas presumindo que sim - e em que ocasião um homem o pratica? Quando cuida do que lhe diz respeito, por acaso ele também cuida de si próprio?

[ALC.] Parece-me que sim.

[SÓC.] E então? Em que ocasião um homem cuida dos pés? Acaso seria quando ele cuida do que diz respeito aos pés?

[ALC.] Não entendo. 


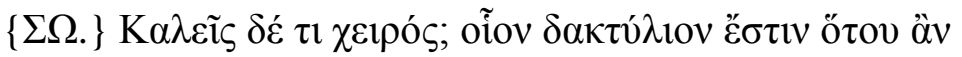

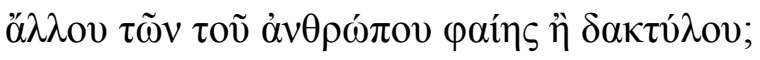

$10\{$ A $\Lambda$.$\} Ở \delta \tilde{\eta} \tau \alpha$.

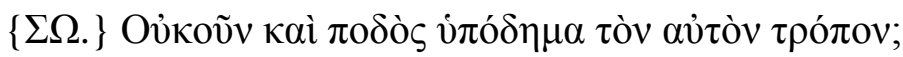

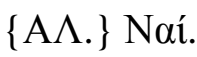

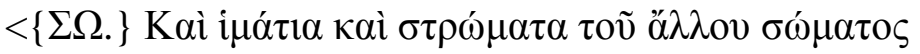
ópoícs;

b $\quad\{$ A $\Lambda$.$\} Naí.>$

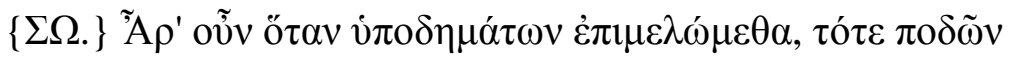
$\dot{\varepsilon} \pi \mu \varepsilon \lambda \circ{ }^{\prime} \mu \varepsilon \theta \alpha$

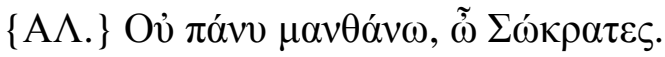

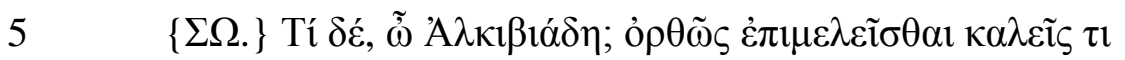

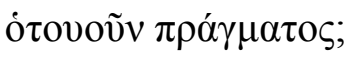

$\{\mathrm{A} \Lambda.\}{ }^{\prime} \mathrm{E} \gamma \omega \gamma \varepsilon$.

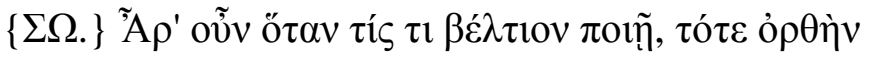

$\lambda \varepsilon \dot{\gamma} \gamma \varepsilon 1 \varsigma \dot{\varepsilon} \pi \mu \mu \dot{\lambda} \lambda \varepsilon 1 \alpha v$

$10 \quad\{$ A $\Lambda$.$\} Naí.$

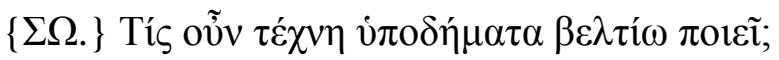

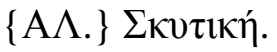

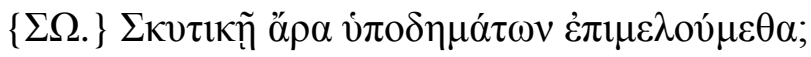

c

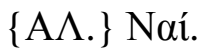

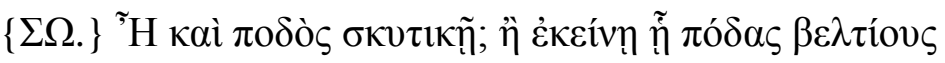
$\pi 010 \tilde{} \mu \varepsilon v$;

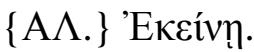

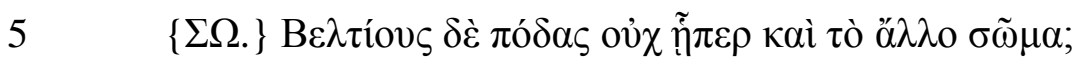

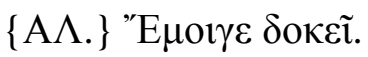

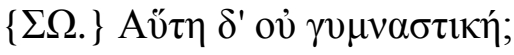

$\{\mathrm{A} \Lambda.\} \mathrm{M} \alpha \dot{\lambda} \imath \tau \tau \alpha$.

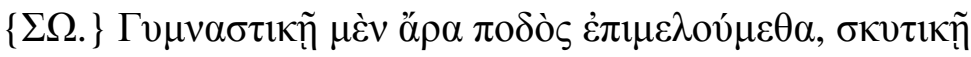


[SÓC.] Há algo que diz respeito à mão, segundo você? Por exemplo: você diria que um anel diz respeito a alguma outra parte do corpo humano que não ao dedo?

[ALC.] Certamente não.

[SÓC.] E não é certo que também os calçados dizem respeito ao pé, da mesma maneira?

[ALC.] Sim.

[SóC.] E os mantos e as mantas não dizem respeito semelhantemente a outras partes do corpo?

[ALC.] Sim.

[SÓC.] Então, quando cuidamos dos calçados, estamos cuidando dos pés?

[ALC.] Ainda não estou entendendo muito bem, ó Sócrates.

[SÓC.] E então, ó Alcibíades? Há algo que você denomina 'cuidar corretamente' de qualquer coisa que seja?

[ALC.] Sim.

[SÓC.] Quando alguém torna algo melhor, porventura é nessa ocasião que você denomina 'cuidar corretamente'?

[ALC.] Sim.

[SÓC.] E qual é a arte que torna os calçados melhores?

[ALC.] A sapataria.

[SÓC.] Cuidamos, portanto, dos calçados através da sapataria?

[ALC.] Sim.

[SÓC.] E cuidamos também dos pés através da sapataria? Ou através daquela arte pela qual tornamos os pés melhores?

[ALC.] Através desta.

[SÓC.] E a que torna os pés melhores não é a mesma que torna melhor o restante do corpo?

[ALC.] Parece-me que sim.

[SÓC.] E ela não é a ginástica?

[ALC.] Exatamente.

[SÓC.] Portanto, cuidamos dos pés através da ginástica e, através da sapataria, 


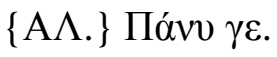

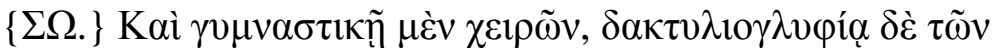

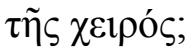

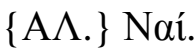

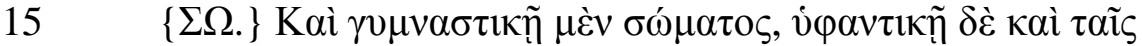

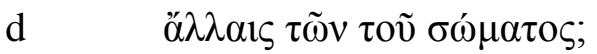

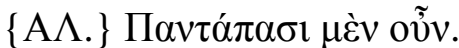

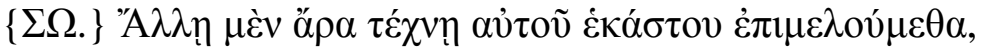

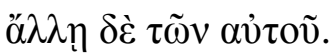

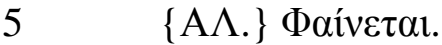

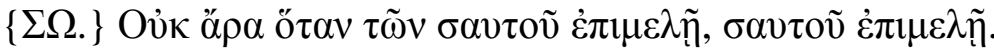

$\{\mathrm{A} \Lambda$.$\} O \delta \alpha \mu \tilde{\omega} \varsigma$.

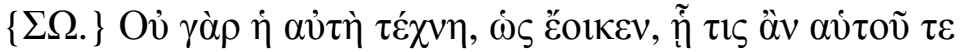

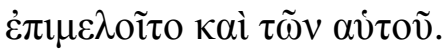

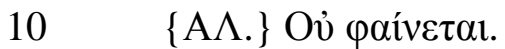

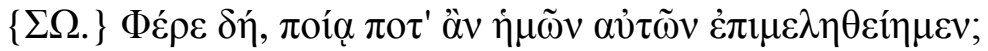

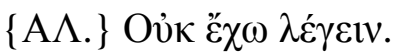

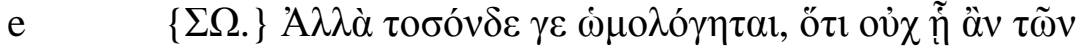

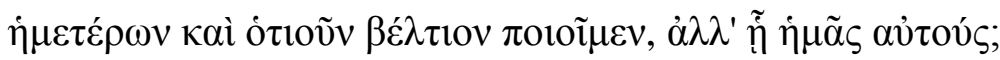

$\{\mathrm{A} \Lambda.\}{ }^{\wedge} \mathrm{A} \lambda \eta \theta \tilde{\eta} \lambda \varepsilon^{\prime} \gamma \varepsilon 1 \zeta$.

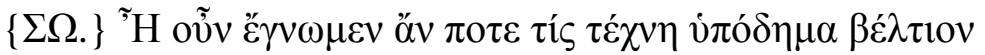

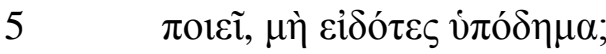

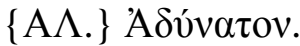

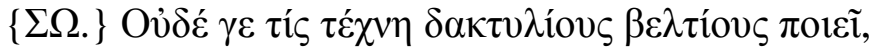

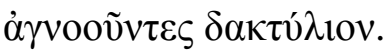

$\{\mathrm{A} \Lambda\}. A \lambda \eta \theta \tilde{\eta}$.

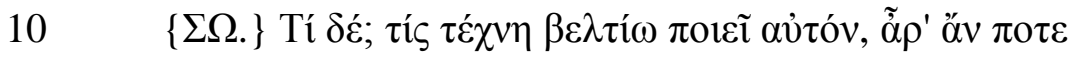

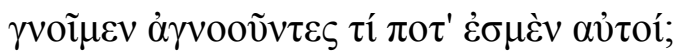


cuidamos do que diz respeito aos pés.

[ALC.] Certamente.

[SÓC.] E, por conseguinte, cuidamos das mãos através da ginástica, enquanto do que diz respeito às mãos, através da ourivesaria.

[ALC.] Sim.

[SÓC.] E cuidamos do corpo através da ginástica, enquanto do que diz respeito ao corpo, através da tecelagem e de outras artes.

[ALC.] Com toda certeza.

[SÓC.] Cuidamos de cada coisa em particular, portanto, através de uma arte, enquanto do que lhe diz respeito, através de outra.

[ALC.] É claro.

[SÓC.] Portanto, quando você cuida daquilo que lhe diz respeito, não está cuidando de si mesmo.

[ALC.] De maneira nenhuma.

[SÓC.] Pois não é através da mesma arte, ao que parece, que alguém cuidaria de si mesmo e do que lhe diz respeito.

[ALC.] É claro que não.

[SÓC.] Vamos lá, então! Qual é a arte, pois, através da qual poderíamos cuidar de nós mesmos?

[ALC.] Não sei lhe responder.

[SÓC.] Mas estamos de acordo neste ponto, ao menos: que não é aquela através da qual tornaríamos melhor qualquer coisa que nos diz respeito, mas aquela através da qual tornaríamos melhores a nós mesmos. Não estamos?

[ALC.] É verdade o que você diz.

[SÓC.] Por acaso, então, poderíamos conhecer qual é a arte que torna melhores os calçados, sem conhecer os calçados?

[ALC.] É impossível.

[SÓC.] E nem tampouco a arte que torna melhores os anéis, desconhecendo o anel.

[ALC.] É verdade.

[SÓC.] E então? Acaso poderíamos conhecer qual arte torna melhor o próprio indivíduo, se fôssemos ignorantes do que nós mesmos somos? 


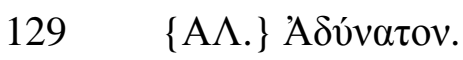

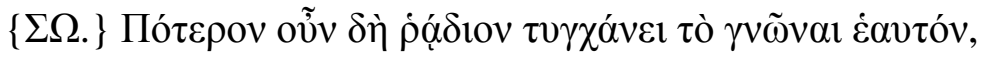

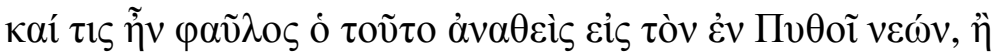

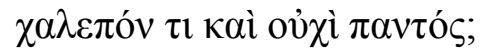

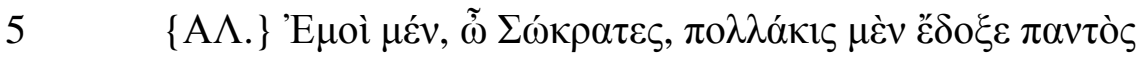

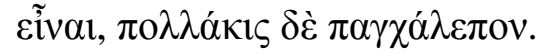

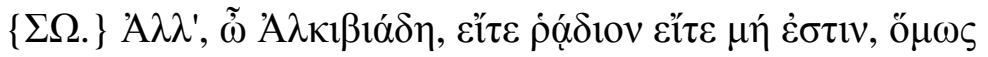

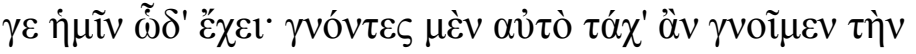

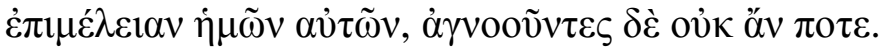

$10 \quad\{\mathrm{~A} \Lambda.\}{ }^{\prime} \mathrm{E} \sigma \tau \imath \tau \alpha \tilde{\tau} \alpha$.

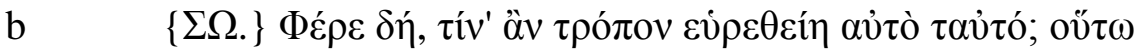

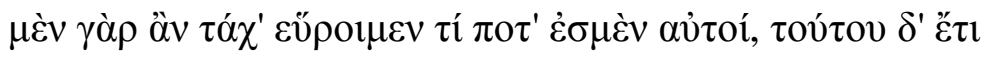

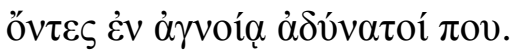

$\{\mathrm{A} \Lambda.\}{ }^{\prime} \mathrm{O} \rho \theta \tilde{\omega} \varsigma \lambda \varepsilon \dot{\gamma} \gamma \varepsilon 1 \varsigma$.

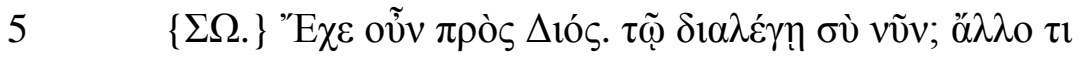
ทे غ́uoí;

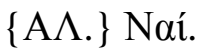

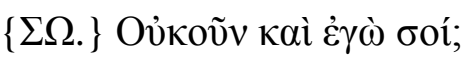

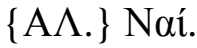

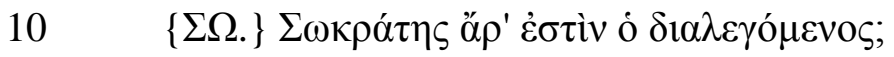

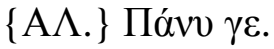

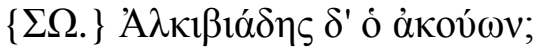

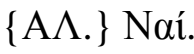

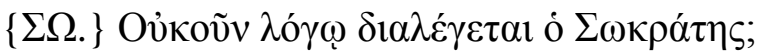

c $\quad\{\mathrm{A} \Lambda$.$\} Tí \mu \eta ́ v ;$

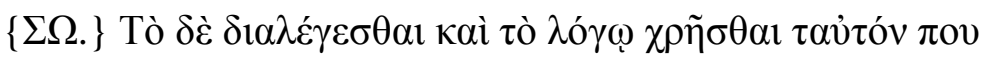
$\kappa \alpha \lambda \varepsilon \tilde{\varsigma} \varsigma$.

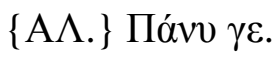

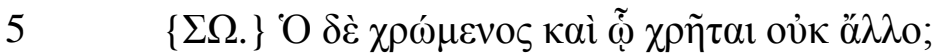


[ALC.] É impossível.

[SÓC.] Porventura, conhecer a si mesmo é algo fácil - e aquele que fixou a inscrição no templo de Delfos era leviano - ou é algo difícil e não para todos?

[ALC.] Muitas vezes me pareceu, ó Sócrates, ser para todos, enquanto outras vezes me pareceu ser algo muito difícil.

[SÓC.] Mas, ó Alcibíades, a despeito de ser fácil ou não, a situação que temos é a seguinte: se conhecêssemos isso, talvez pudéssemos conhecer como cuidar de nós mesmos, ao passo que se o ignorássemos, não poderíamos conhecê-lo.

[ALC.] É o que sucede.

[SÓC.] Vamos lá, então! De que maneira esse 'a si mesmo' poderia ser $b$ descoberto? Pois, assim, talvez pudéssemos descobrir o que nós mesmos somos, porém, se ainda o ignorássemos, seria decerto impossível.

[ALC.] É correto o que você diz.

[SÓC.] Um momento, por Zeus! Com quem você dialoga agora? Com alguma outra pessoa, ou comigo?

[ALC.] Com você.

[SÓC.] E, sem dúvidas, também eu com você?

[ALC.] Sim.

[SÓC.] E Sócrates, portanto, é o condutor do diálogo?

[ALC.] Certamente.

[SÓC.] E Alcibíades, o ouvinte?

[ALC.] Sim.

[SÓC.] E Sócrates não está dialogando com palavras?

[ALC.] E daí?

[SÓC.] E você considera como a mesma coisa o ato de dialogar e o de usar palavras, suponho eu.

[ALC.] Certamente.

[SóC.] E aquele que usa e aquilo que é usado não são coisas diferentes? 


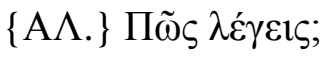

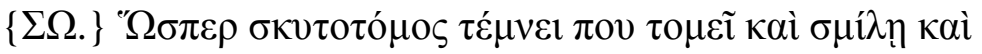

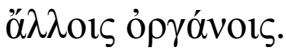

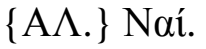

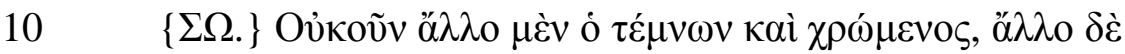
oĩs $\tau \dot{\varepsilon} \mu \nu \omega v \chi \rho \tilde{\eta} \tau \alpha \iota ;$

$\{\mathrm{A} \Lambda.\} \Pi \tilde{\omega} \varsigma \gamma \grave{\alpha} \rho$ oü;

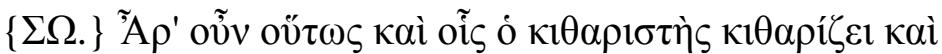

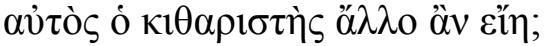

$15 \quad\{$ A $\Lambda$.$\} Naí.$

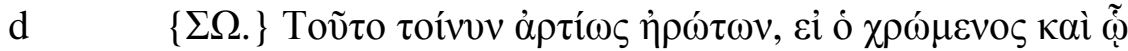

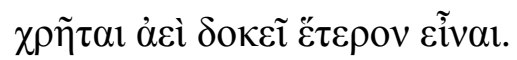

$\{\mathrm{A} \Lambda.\} \Delta о \kappa \varepsilon \tilde{i}$.

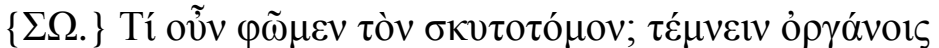

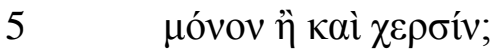

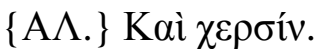

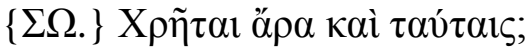

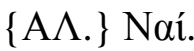

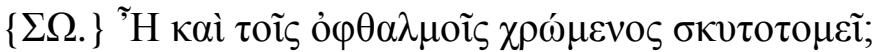

$10 \quad\{\mathrm{~A} \Lambda$.$\} Naí.$

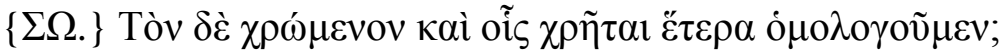

$\{$ A $\Lambda$.$\} Naí.$

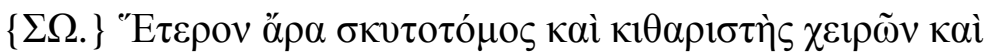

e

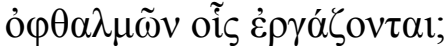

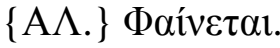

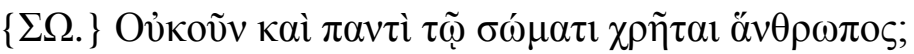

$\{\mathrm{A} \Lambda.\} \Pi \alpha \dot{v} v \gamma \gamma \varepsilon$.

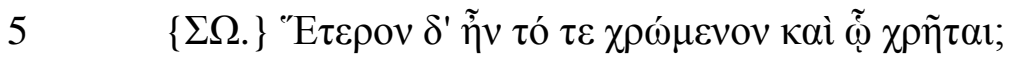

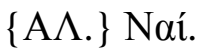


[ALC.] O que você está dizendo?

[SÓC.] Por exemplo: o sapateiro trabalha o corte com a faca, o estilete e outros instrumentos.

[ALC.] Sim.

[SÓC.] E aquele que corta e usa os instrumentos, e aquilo que é usado por ele para cortar, não são coisas diferentes?

[ALC.] Como não seriam?

[SÓC.] Porventura não seriam também coisas diferentes os instrumentos que o citarista utiliza quando toca, e o próprio citarista?

[ALC.] Sim.

[SÓC.] Bem, era isso o que eu estava lhe perguntando há pouco: se aquele d que usa e aquilo que é usado parecem sempre ser coisas diferentes.

[ALC.] Sim, parecem.

[SÓC.] Então, o que podemos dizer do sapateiro? Que ele corta somente com seus instrumentos, ou também com as mãos?

[ALC.] Também com as mãos.

[SÓC.] Portanto, ele também as utiliza.

[ALC.] Sim.

[SÓC.] E utiliza também os olhos ao confeccionar calçados?

[ALC.] Sim.

[SÓC.] E nós concordamos que aquele que usa e aquilo que é usado são coisas diferentes, não é?

[ALC.] Sim.

[SÓC.] Os sapateiros e os citaristas, portanto, são distintos das mãos e dos olhos com os quais exercem seus ofícios.

[ALC.] É claro.

[SÓC.] E o homem não usa o corpo como um todo?

[ALC.] Certamente.

[SÓC.] E não são distintos aquele que usa e aquilo que é usado?

[ALC.] Sim. 


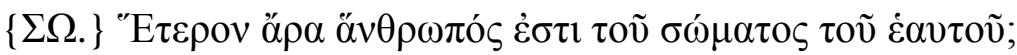

$\{\mathrm{A} \Lambda$.$\} 'Еоккеv.$

$\{\Sigma \Omega$.$\} Tí \pi \mathrm{o} \tau^{\prime}$ oṽv ơ ớv $\theta \rho \omega \pi \mathrm{o}$;

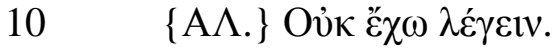

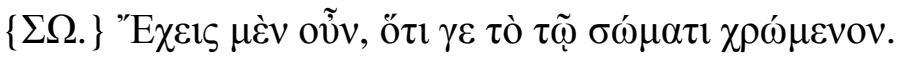

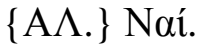

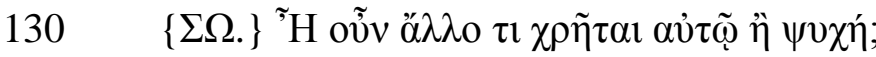

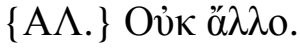

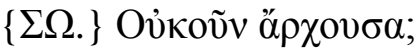

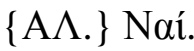

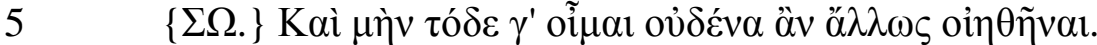

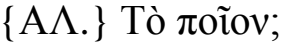

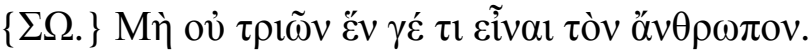

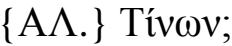

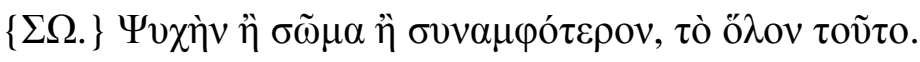

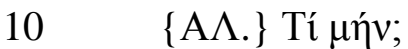

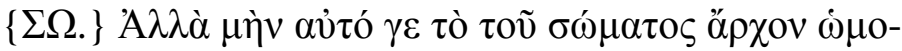

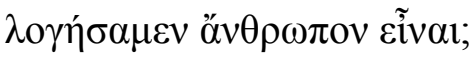

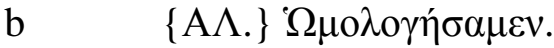

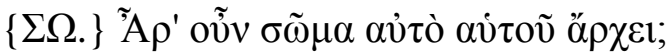

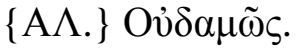

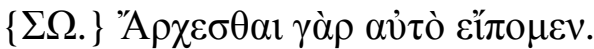

$5 \quad\{$ A $\Lambda$.$\} Naí.$

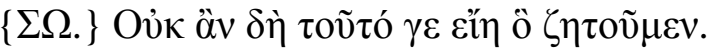

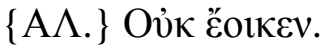

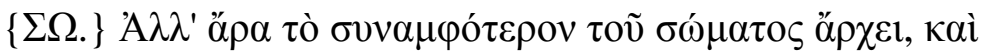

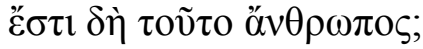

$10\{\mathrm{~A} \Lambda.\}{ }^{\prime} \mathrm{I} \sigma \omega \varsigma \delta \tilde{\eta} \tau \alpha$.

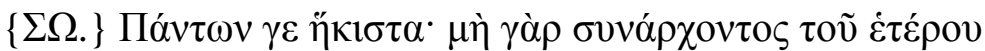


[SÓC.] O homem, portanto, é distinto de seu próprio corpo.

[ALC.] É plausível.

[SÓC.] Então, o que é o homem?

[ALC.] Não sei responder.

[SÓC.] Sim, você pode dizer: aquilo que se serve do corpo.

[ALC.] Certo.

[SÓC.] E então, há outra coisa que se serve do corpo além da alma?

[ALC.] Não há.

[SÓC.] E ela também não o comanda?

[ALC.] Sim.

[SÓC.] De fato, penso que ninguém consideraria de modo diverso o seguinte ponto.

[ALC.] O quê?

[SÓC.] Que o homem seja uma destas três coisas.

[ALC.] Quais?

[SÓC.] Ou alma, ou corpo, ou o conjunto de ambos, isso é, o todo.

[ALC.] E então?

[SÓC.] Com efeito, não concordamos que o homem é precisamente aquilo que comanda o corpo?

[ALC.] Concordamos.

[SÓC.] Por acaso o próprio corpo comanda a si mesmo?

[ALC.] De maneira nenhuma.

[SÓC.] Pois já dissemos que ele é comandado.

[ALC.] Sim.

[SÓC.] Então, isso não poderia ser o que investigamos.

[ALC.] É plausível que não.

[SÓC.] Portanto, será que é o conjunto de ambos que comanda o corpo, e o homem seria precisamente isso?

[ALC.] Talvez seja.

[SÓC.] De modo nenhum: pois, se um deles não participa do comando, 


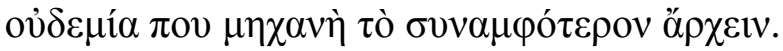

$\{\mathrm{A} \Lambda\}. ' \mathrm{O} \rho \theta \tilde{\omega} \varsigma$.

c

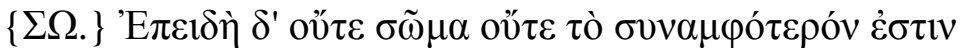

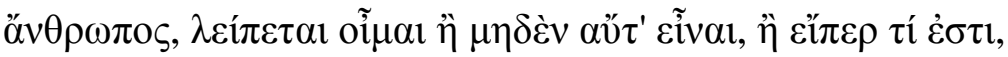

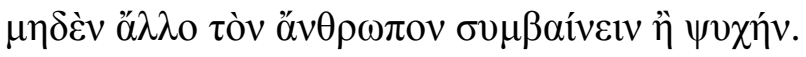

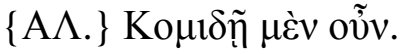

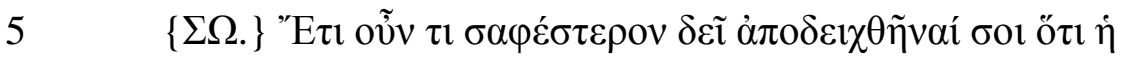

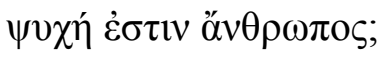

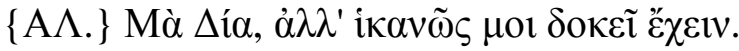

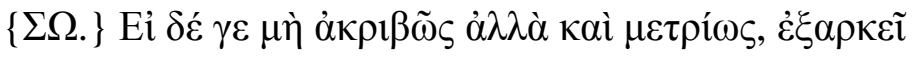

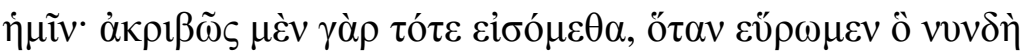

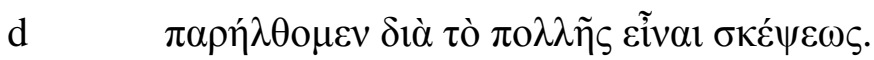

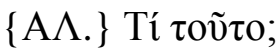

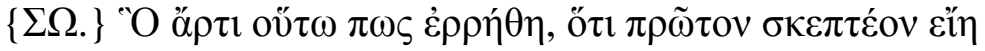

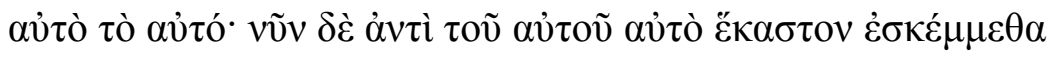

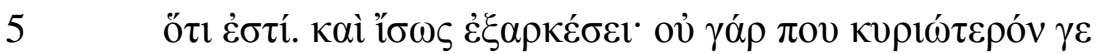

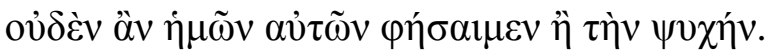

$\{\mathrm{A} \Lambda$.$\} Ở \delta \tilde{\eta} \tau \alpha$.

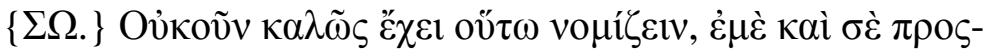

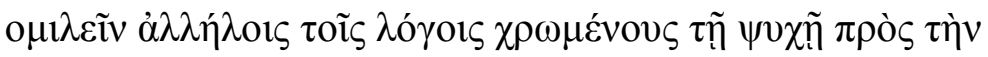

$10 \quad \psi v \chi \eta ́ v$

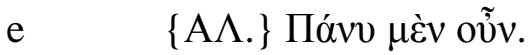

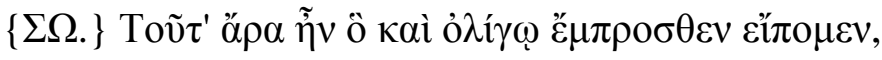

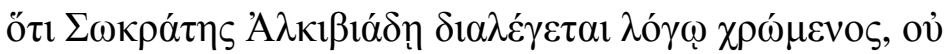

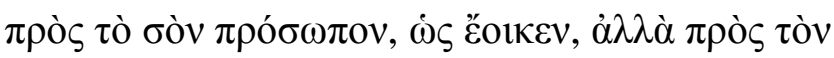

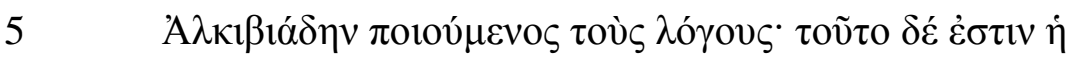

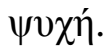

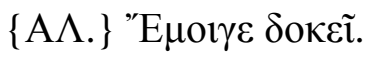

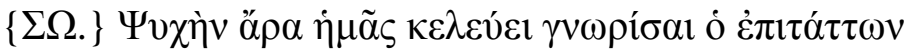


não há como ambos comandarem, suponho eu.

[ALC.] Está correto.

[SÓC.] Uma vez que o homem não é nem o corpo e nem o conjunto de c corpo e alma, eu penso que ainda lhe resta ou não ser coisa alguma, ou, se for algo, não ser outra coisa senão a alma.

[ALC.] Sim, perfeitamente.

[SÓC.] Então, ainda é preciso lhe demonstrar de uma maneira mais clara que homem é a alma?

[ALC.] Por Zeus, parece-me já ser suficiente.

[SÓC.] Se foi demonstrado de modo equilibrado, ainda que não de maneira precisa, para nós basta; pois saberemos com precisão, quando descobrirmos o que há pouco negligenciamos, uma vez que requeria uma longa d investigação.

[ALC.] O que é isso?

[SÓC.] O que há pouco foi dito: que primeiro devemos examinar aquele 'a si mesmo'. Mas agora, em vez desse 'a si mesmo', acabamos de examinar o que é cada indivíduo em si mesmo. Talvez isso baste, pois, suponho eu, poderíamos dizer que não há nada mais soberano em nós mesmos do que a alma.

[ALC.] Não há, certamente.

[SÓC.] E não está certo considerar que, quando eu e você conversamos um com o outro, servindo-nos de palavras, é uma alma que se dirige a outra?

[ALC.] Certamente.

[SÓC.] Portanto, era isto o que há pouco dizíamos, que Sócrates dialoga com Alcibíades servindo-se de palavras, não as dirigindo ao seu rosto, ao que parece, mas a Alcibíades, isto é, à sua alma.

[ALC.] Assim me parece.

[SÓC.] A conhecer a alma, portanto, nos ordena a prescrição 


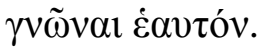

$131 \quad\{\mathrm{~A} \Lambda.\}{ }^{\prime}$ Eoikev.

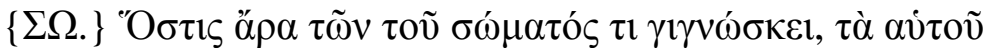

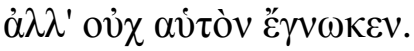

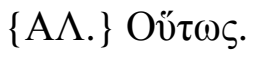

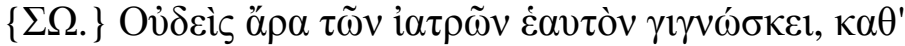

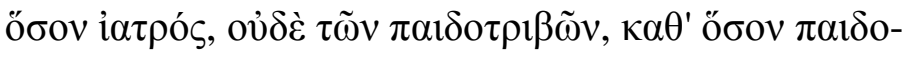

$\tau \rho i ́ \beta\rceil$.

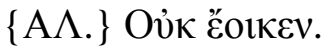

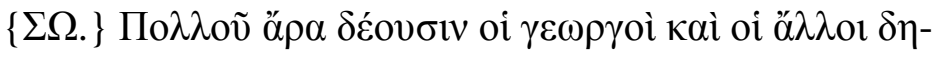

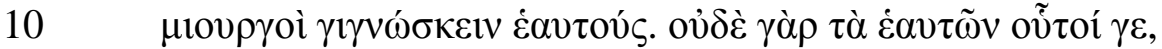

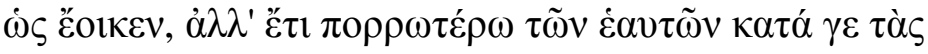

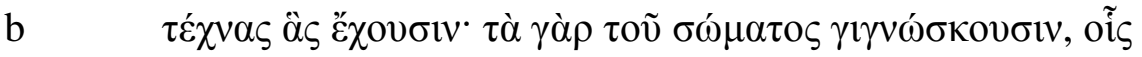

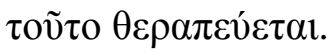

$\{\mathrm{A} \Lambda$.$\} 'A \lambda \eta \theta \tilde{\eta} \lambda \varepsilon \dot{\varepsilon \varepsilon \varepsilon 1 \zeta . ~}$

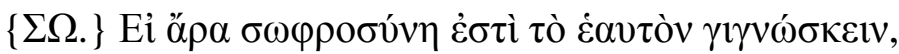

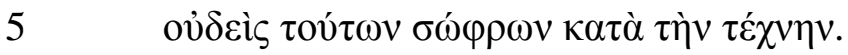

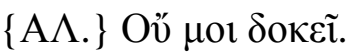

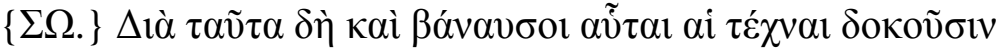

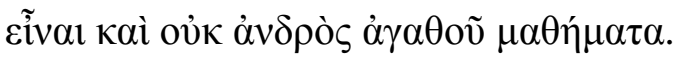

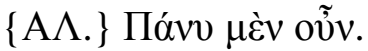

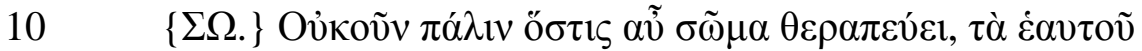

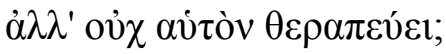

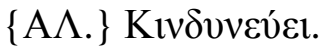

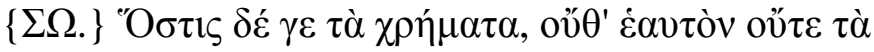

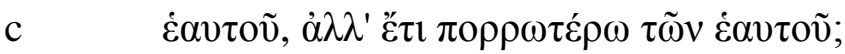

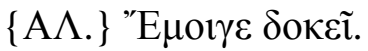

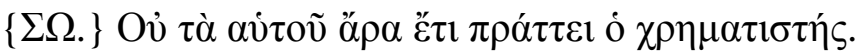

$\{\mathrm{A} \Lambda.\}{ }^{\prime} \mathrm{O} \rho \theta \tilde{\omega} \varsigma$. 
'conheça a si mesmo'.

[ALC.] É plausível.

[SÓC.] E, então, quem quer que conheça algo relativo ao corpo, conhece o que diz respeito a si, mas não a si mesmo.

[ALC.] Assim é.

[SÓC.] Portanto, nenhum médico conhece a si mesmo, enquanto médico, tampouco qualquer mestre de ginástica, enquanto mestre de ginástica.

[ALC.] Parece que não.

[SÓC.] Os agricultores e os demais artífices, portanto, estão longe de conhecerem a si mesmos. Eles, ao que parece, nem conhecem o que lhes diz respeito; as coisas que conhecem, referentes às artes que ministram, estão ainda mais distantes de si mesmos, pois conhecem aquilo que diz respeito ao corpo, por meio do que cuidam dele.

[ALC.] Você diz a verdade.

[SÓC.] Se, portanto, a temperança consiste em conhecer a si mesmo, nenhum deles é temperante por causa de sua arte.

[ALC.] Parece-me que não.

[SÓC.] E também em razão disso, essas artes parecem ser vulgares, e não aprendizados de homens bons.

[ALC.] Certamente.

[SÓC.] E, repetindo: será que quem cuida do corpo está cuidando daquilo que diz respeito a si mesmo, mas não de si mesmo?

[ALC.] É bem possível.

[SÓC.] E aquele que cuida das riquezas não está cuidando nem de si mesmo e nem daquilo que diz respeito a si mesmo, mas de coisas ainda mais distantes disso?

[ALC.] Parece-me que sim.

[SÓC.] Tampouco o negociante, portanto, se ocupa daquilo que diz respeito a si mesmo.

[ALC.] É correto. 


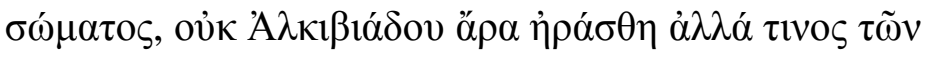

A $\lambda \kappa \iota ß ı \alpha ́ \delta o v$.

$\{\mathrm{A} \Lambda.\}{ }^{\prime} \mathrm{A} \lambda \eta \theta \tilde{\eta} \lambda \varepsilon^{\prime} \gamma \varepsilon 1 \varsigma$.

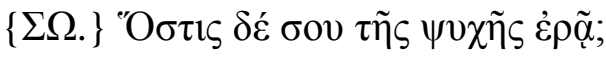

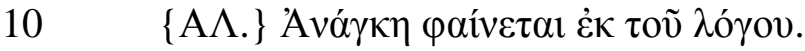

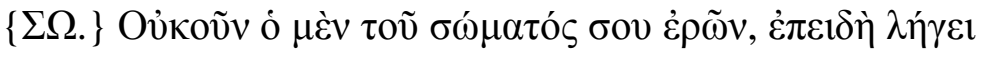

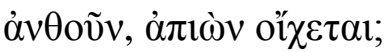

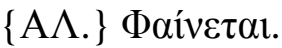

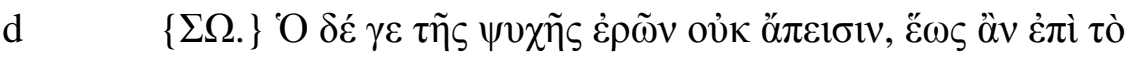

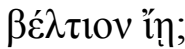

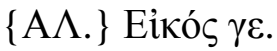

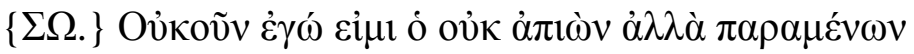

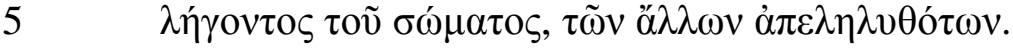

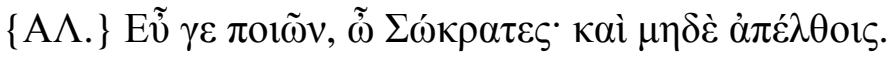

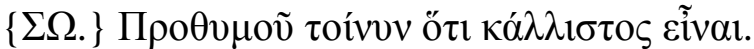

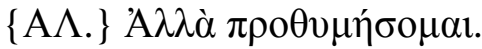

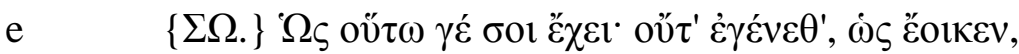

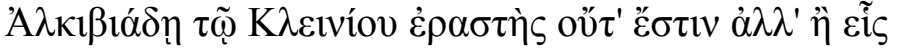

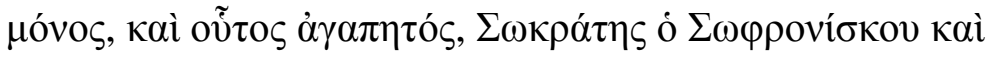

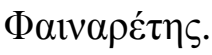
$\{\mathrm{A} \Lambda.\}{ }^{\prime} \mathrm{A} \lambda \eta \theta \tilde{\eta}$.

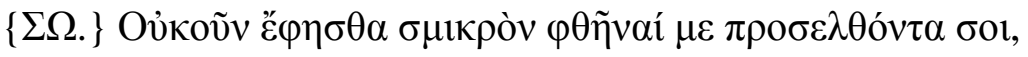

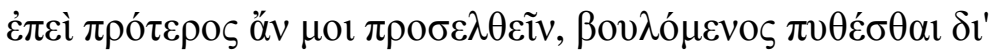

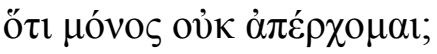

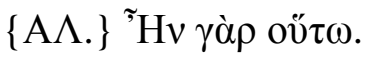

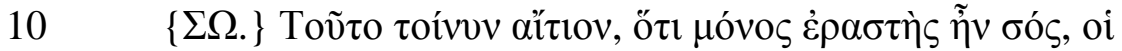

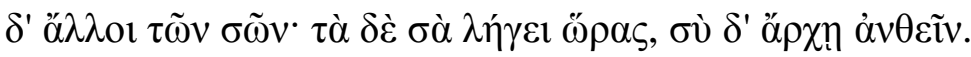

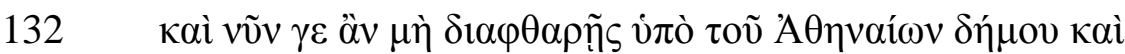


[SÓC.] Se, por conseguinte, alguém foi amante do corpo de Alcibíades, não amou Alcibíades, mas aquilo que diz respeito a Alcibíades.

[ALC.] Você diz a verdade.

[SÓC.] Mas quem o ama, ama a sua alma?

[ALC.] É forçoso pelo argumento.

[SÓC.] E não é verdade que, quando finda a flor de sua juventude, o amante de seu corpo parte para longe?

[ALC.] É claro.

[SÓC.] E o amante da sua alma, por sua vez, não partirá, enquanto você d estiver em fase de aprimoramento, não é?

[ALC.] É plausível que sim.

[SÓC.] Eu sou, então, aquele que não parte, mas permanece ao seu lado mesmo findando a plenitude do seu corpo, enquanto os demais já se retiraram.

[ALC.] E fez bem, ó Sócrates. E espero que você não parta.

[SÓC.] Então, se esforce para que seja o mais belo possível!

[ALC.] Sim, me esforçarei!

[SÓC.] Eis a sua condição: não houve e não há, ao que parece, nenhum amante de Alcibíades, filho de Clínias, com exceção de um, que merece ser amado: Sócrates, filho de Sofronisco e Fenarete.

[ALC.] É verdade.

[SÓC.] E você não disse que eu me antecipei por pouco a você no momento de minha aproximação, uma vez que você estava na iminência de me interpelar, desejoso de saber por que razão eu era o único a não ter me retirado?

[ALC.] Foi isso mesmo.

[SÓC.] Eis a razão: eu era o seu único amante, ao passo que os demais o eram daquilo que lhe diz respeito. Enquanto finda o frescor das coisas que lhe dizem respeito, você está começando a florescer. E, agora, se você não for arruinado pelo povo ateniense nem 


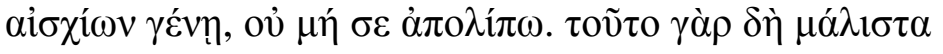

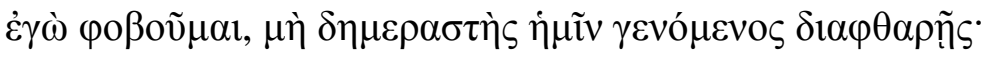

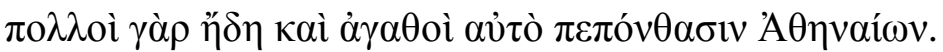

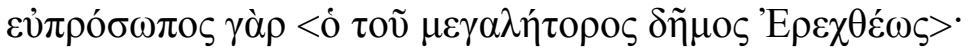

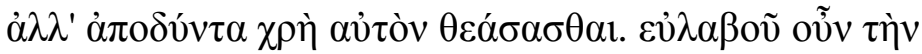

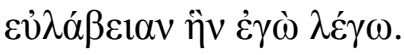

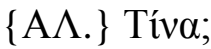

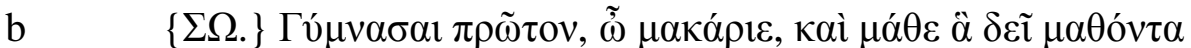

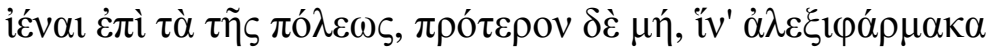

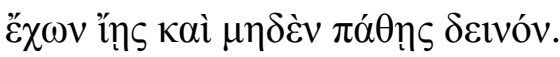

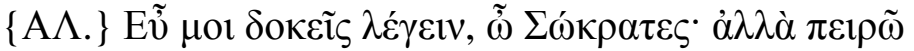

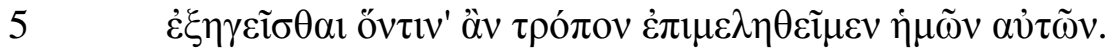

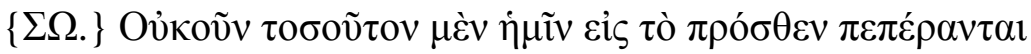

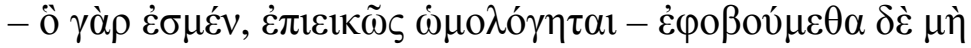

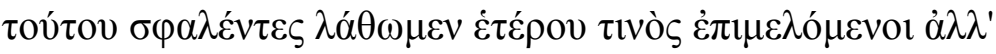

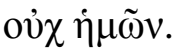

$10\{\mathrm{~A} \Lambda.\}{ }^{\prime} \mathrm{E} \sigma \tau \imath \tau \alpha \tilde{\tau} \tau \alpha$.

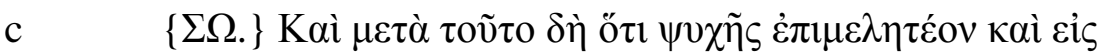

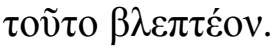

$\{\mathrm{A} \Lambda.\} \Delta \tilde{\eta} \lambda \mathrm{ov}$.

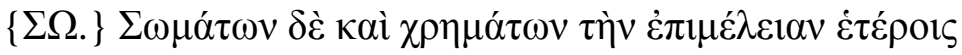
$\pi \alpha \rho \alpha \delta$ o $\varepsilon \dot{o v}$.

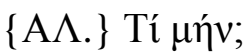

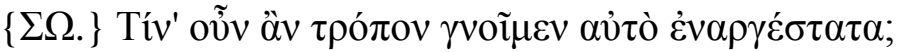

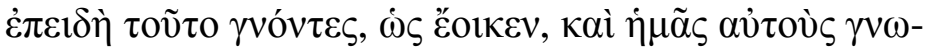

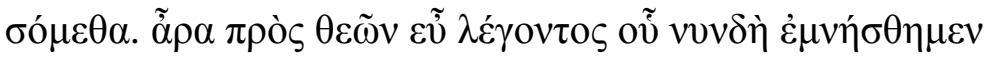

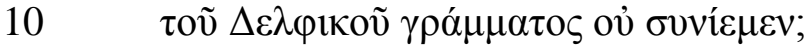

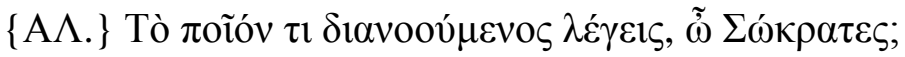

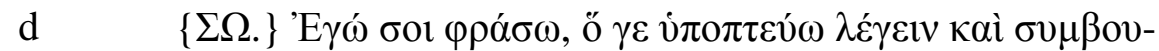


cair numa condição vergonhosa, eu não pretendo abandoná-lo. Pois é isto o que mais temo: que você se arruíne ao se tornar amante do povo. Pois muitos atenienses nobres já passaram por essa situação. De belo aspecto é o povo de Erecteu, de grande coração: mas é preciso despi-lo para contemplálo. Então, tome esta precaução a qual me refiro!

[ALC.] Qual?

[SÓC.] Primeiro, exercite-se, ó afortunado, e aprenda aquilo que lhe é b devido para se envolver com os assuntos da cidade! Antes disso, jamais o faça, a fim de que, quando se envolver com eles, você tenha o antídoto e não padeça de nenhum mal!

[ALC.] Suas recomendações me parecem certas, ó Sócrates. Mas tente me explicar de que modo deveríamos cuidar de nós mesmos!

[SÓC.] Bem, sem dúvida avançamos até este ponto - pois chegamos a um consenso razoável sobre o que somos - mas temíamos fracassar nisso não percebendo que cuidávamos de outra coisa, mas não de nós mesmos.

[ALC.] Exatamente.

[SÓC.] E, depois disso, concordamos que devemos cuidar de nossa alma e c visar a isso.

[ALC.] Obviamente.

[SÓC.] E que devemos deixar para outros o cuidado do corpo e das riquezas. [ALC.] Com certeza.

[SÓC.] De que maneira, então, poderíamos conhecer a alma da maneira mais clara possível? Quando estivermos cientes disso, ao que parece, conheceremos também a nós mesmos. Pelos deuses, acaso não compreendemos as belas palavras da inscrição em Delfos à qual fizemos menção há pouco?

[ALC.] Com qual intenção você diz isso, ó Sócrates?

[SÓC.] Irei lhe explicar o que eu suspeito que nos diz e recomenda 


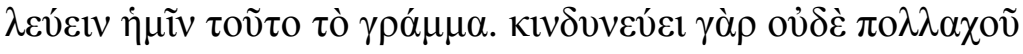

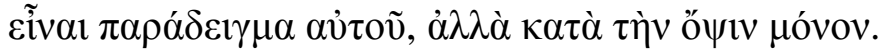

$\{\mathrm{A} \Lambda.\} \Pi \tilde{\omega} \varsigma \tau о \tilde{\tau} \tau \mathrm{\lambda} \dot{\varepsilon} \gamma \varepsilon เ \varsigma$

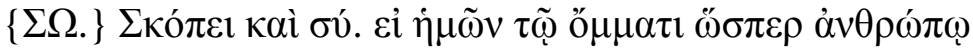

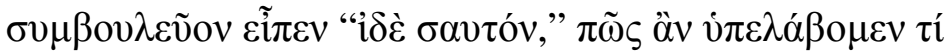

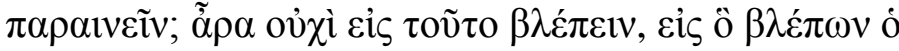

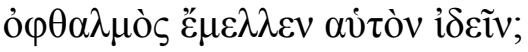

$\{\mathrm{A} \Lambda.\} \Delta \tilde{\eta} \lambda \mathrm{ov}$.

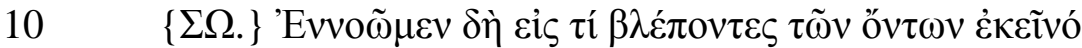

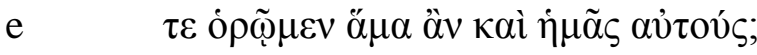

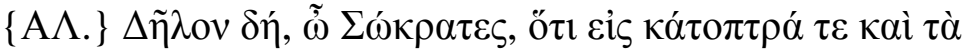
$\tau 01 \alpha \tilde{\tau} \tau$.

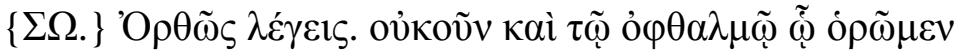

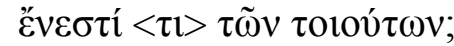

$\{\mathrm{A} \Lambda.\} \Pi^{\alpha} v v \gamma \varepsilon$.

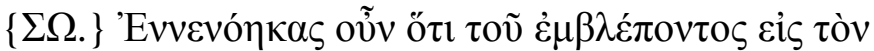

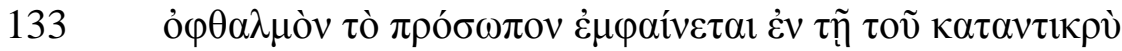

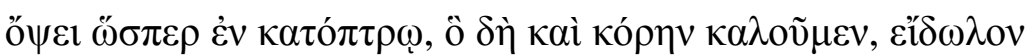

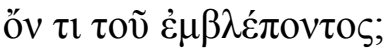

$\{\mathrm{A} \Lambda$.$\} 'A \lambda \eta \theta \tilde{\eta} \lambda \dot{\varepsilon} \gamma \varepsilon 1 \zeta$.

5

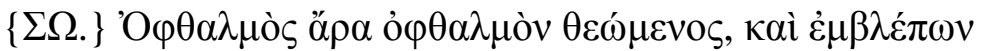

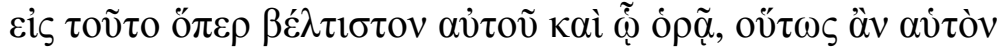
¡ool.

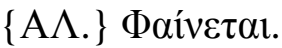

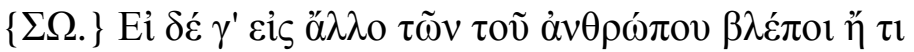

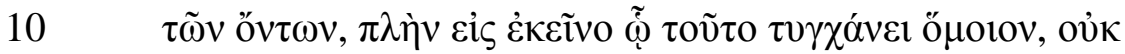
ő $\varepsilon \tau \alpha l \dot{\varepsilon} \alpha v \tau o ́ v$.

b $\quad\{\mathrm{A} \Lambda\}. A \lambda \eta \theta \tilde{\eta} \lambda \varepsilon \dot{\gamma} \gamma \varepsilon 1 \zeta$.

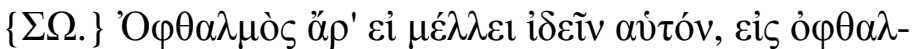


aquela inscrição. Pois é bem possível que não haja muitos exemplos disso, senão apenas com relação à visão.

[ALC.] O que você quer dizer com isso?

[SÓC.] Examine você também! Se, a inscrição aconselhasse o nosso olho, como a um homem, e dissesse 'Veja a si mesmo', como entenderíamos a recomendação? Acaso não seria para voltar o olhar para o que, ao mirá-lo, o olho veria a si mesmo?

[ALC.] Obviamente.

[SÓC.] Reflitamos, então: ao olharmos para o quê dentre as coisas existentes, veríamos ao mesmo tempo a ela e a nós mesmos?

[ALC.] É óbvio, ó Sócrates, que para espelhos e coisas similares.

[SÓC.] É correto o que você diz. E não é verdade que há algo similar também no olho com o qual enxergamos?

[ALC.] Certamente.

[SÓC.] Você não percebe, pois, que a face daquele que olha no olho de alguém aparece na visão de quem o vê, tal como em um espelho, o que nós chamamos de pupila, que é um simulacro de quem está olhando?

[ALC.] Você diz a verdade.

[SÓC.] Quando um olho, portanto, contempla outro olho e fixa o seu olhar justamente na sua melhor parte - ou seja, a parte com a qual se vê - veria assim a si mesmo.

[ALC.] É claro.

[SÓC.] Mas se ele olhar para qualquer outra parte do homem ou para qualquer outra coisa existente, não verá a si mesmo, a não ser que olhe para algo que aconteça de lhe ser semelhante.

[ALC.] É verdade o que você diz.

[SÓC.] Se, portanto, o olho pretende ver a si mesmo, para outro olho 


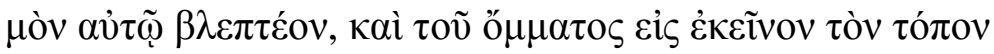

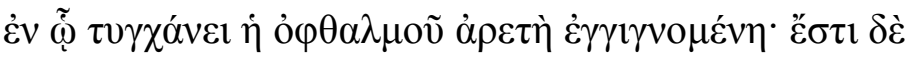

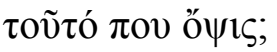

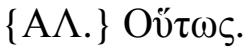

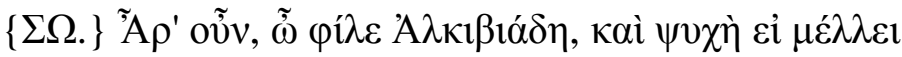

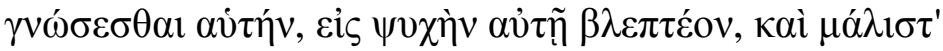

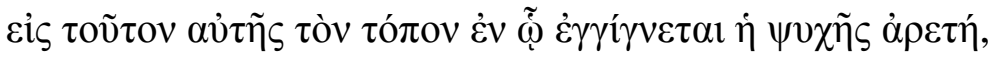

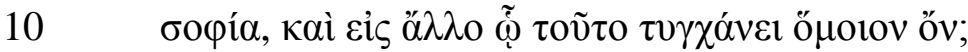
$\{\mathrm{A} \Lambda$.$\} ’Е$

c

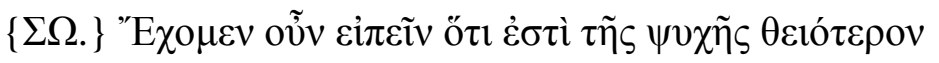

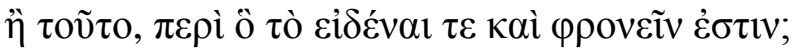

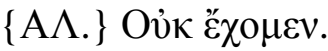

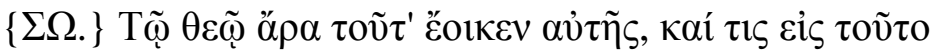

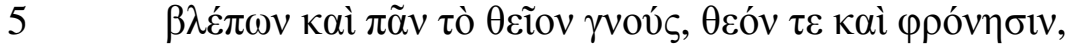

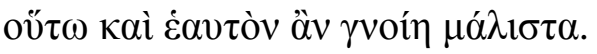

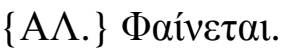

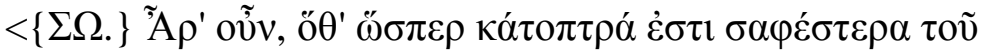

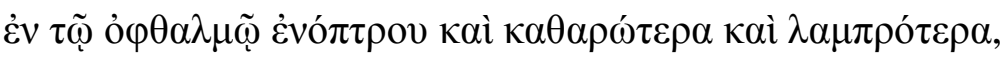

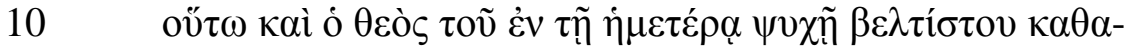

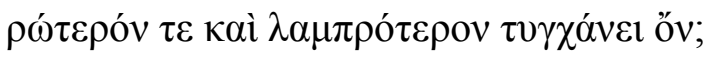

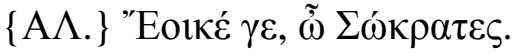

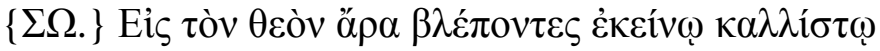

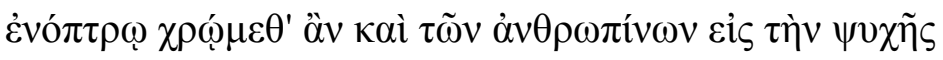

15 $\dot{\eta} \mu \tilde{\alpha} \varsigma \alpha u ̉ \tau o u ́ \varsigma$.

A $\Lambda$.$\} Naí.>$

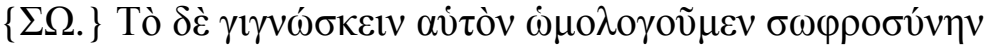
Eĩval;

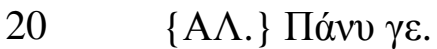


ele deve olhar, e diretamente naquela região em que se encontra a virtude do olho - que é a visão, presumo eu.

[ALC.] Isso mesmo.

[SÓC.] Então, ó caro Alcibíades, se também a alma pretende conhecer a si mesma, porventura ela não deve olhar para uma alma, e, mais precisamente, na região em que se encontra a sua virtude, a sabedoria, ou para alguma outra coisa que aconteça de lhe ser semelhante?

[ALC.] Parece-me que sim, ó Sócrates.

[SÓC.] Podemos dizer, então, que há algo mais divino na alma do que c aquilo que se refere ao conhecer e compreender?

[ALC.] Não podemos.

[SÓC.] Esse aspecto da alma, portanto, se assemelha à divindade, e quem olhasse em sua direção e compreendesse tudo o que é divino - ou seja, deus e inteligência - conheceria também a si mesmo da melhor maneira.

[ALC.] É claro.

[SÓC.] Então, assim como os espelhos são mais claros, mais límpidos e mais luminosos do que a superfície de nosso olho, porventura também o deus não é mais puro e mais luminoso do que o que há de melhor em nossa alma?

[ALC.] É o que parece, ó Sócrates.

[SÓC.] Poderíamos nos servir, portanto, do espelho mais belo quando olhássemos para o deus e para a virtude da alma humana, e, dessa forma, veríamos e conheceríamos da melhor maneira a nós mesmos.

[ALC.] Sim.

[SÓC.] E não concordamos que a temperança é conhecer a si mesmo?

[ALC.] Certamente. 


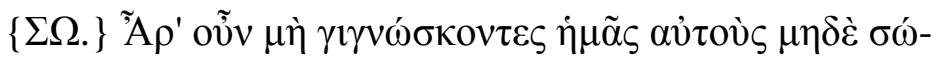

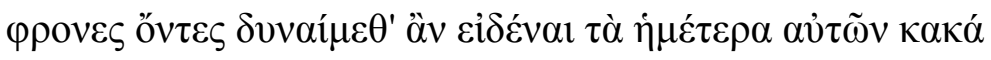
$\tau \varepsilon \kappa \alpha \grave{\alpha} \alpha \gamma \alpha \theta \dot{\alpha}$;

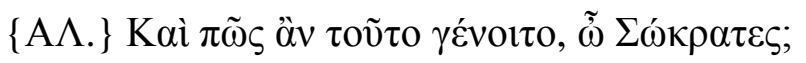

d

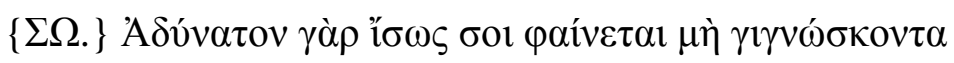

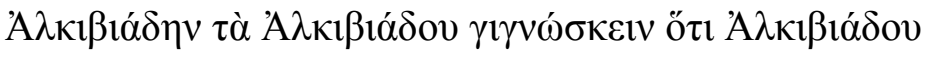

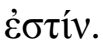

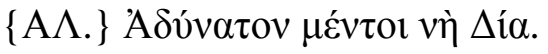

5

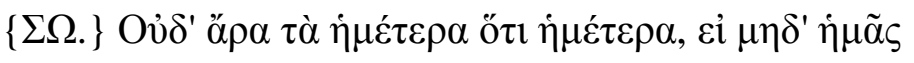

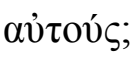

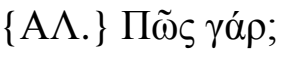

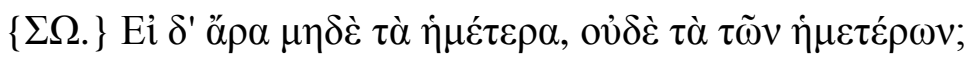

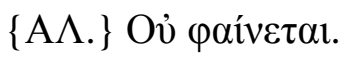

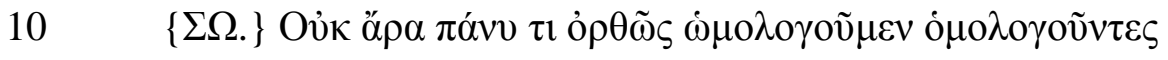

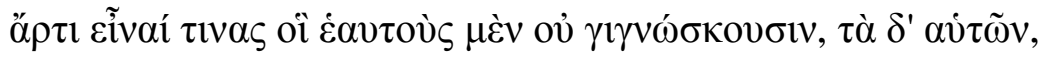

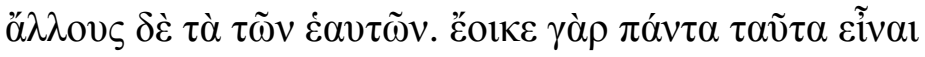

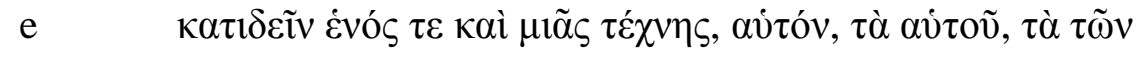
$\dot{\varepsilon} \alpha v \tau$ ก

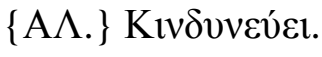

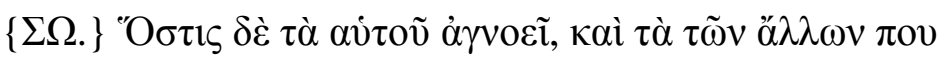

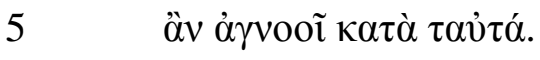

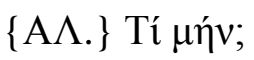

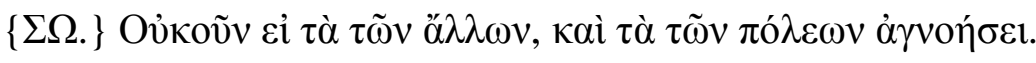

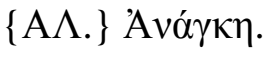

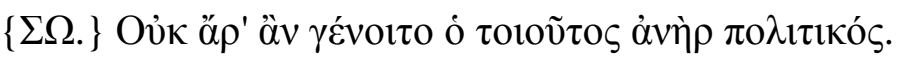

$10 \quad\{\mathrm{~A} \Lambda$.$\} Ỏ̉ \delta \tilde{\eta} \tau \alpha$.

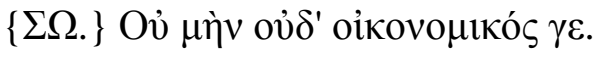

$134\{$ A $\Lambda$.$\} Ỏ̉ \delta \tilde{\eta} \tau \alpha$.

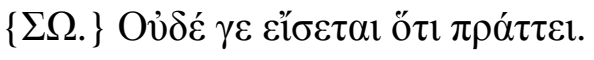


[SÓC.] Acaso, então, sem conhecermos a nós mesmos e sem sermos temperantes, seríamos capazes de reconhecer as coisas boas e as más que nos dizem respeito?

[ALC.] E como isso poderia acontecer, ó Sócrates?

[SÓC.] Talvez lhe pareça impossível reconhecer, sem conhecer Alcibíades, d que aquilo que diz respeito a Alcibíades é de Alcibíades.

[ALC.] Sim, por Zeus, é impossível.

[SÓC.] E, portanto, impossível reconhecer que diz respeito a nós aquilo que nos diz respeito, sem conhecer a nós mesmos?

[ALC.] Como seria possível?

[SÓC.] E se, então, não reconhecemos o que nos diz respeito, também não podemos reconhecer o que diz respeito àquilo que nos diz respeito, não é?

[ALC.] É claro que não podemos.

[SÓC.] Não foi com muito acerto, portanto, que há pouco concordamos que existem aqueles que não conhecem a si mesmos, mas o que lhes diz respeito, enquanto outros, o que diz respeito àquilo que lhes diz respeito. Pois tudo isso parece ser contemplado por um único indivíduo e uma única arte: ele e próprio, o que lhe diz respeito, e o que diz respeito ao que lhe diz respeito.

[ALC.] É bem possível.

[SÓC.] E quem quer que ignore aquilo que lhe diz respeito também ignoraria, suponho eu, o que diz respeito aos outros, pela mesma razão.

[ALC.] Com certeza.

[SÓC.] E se não conhece o que diz respeito aos outros, também ignorará o que diz respeito às cidades.

[ALC.] É forçoso.

[SÓC.] E um homem de tal tipo, então, não poderia se tornar político.

[ALC.] É certo que não.

[SÓC.] E tampouco um administrador de sua casa.

[ALC.] Certamente não.

[SóC.] E nem saberá o que está fazendo. 


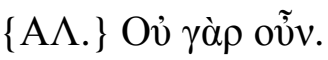

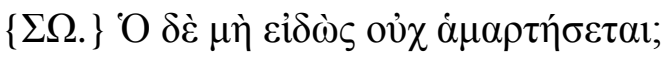

$5 \quad\{\mathrm{~A} \Lambda.\} \Pi \operatorname{ó}^{2} v \boldsymbol{\gamma \varepsilon .}$

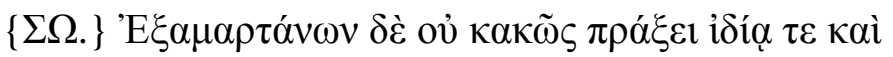

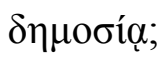

$\{\mathrm{A} \Lambda.\} \Pi \tilde{}$ ตั $\delta^{\prime}$ oü;

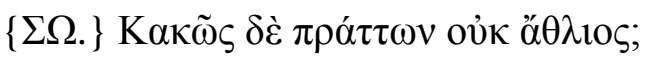

$10 \quad\{\mathrm{~A} \Lambda.\} \Sigma \varphi \delta^{\delta} \rho \alpha \gamma \varepsilon$.

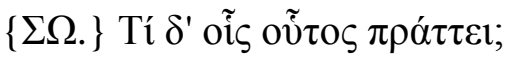

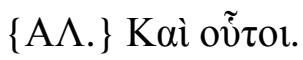

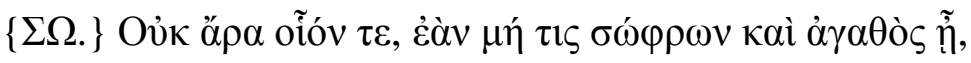

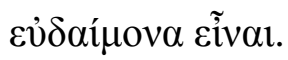

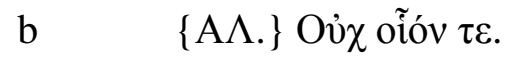

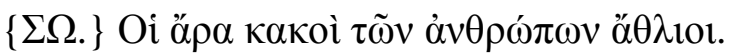

$\{\mathrm{A} \Lambda.\} \Sigma \varphi o ́ \delta \rho \alpha \gamma \varepsilon$.

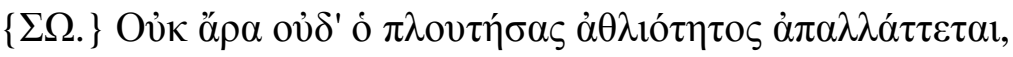

$5 \quad \dot{\alpha} \lambda \lambda^{\prime}$ ó $\sigma \omega \varphi \rho \circ v \eta ́ \sigma \alpha \varsigma$.

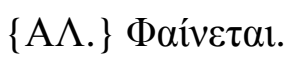

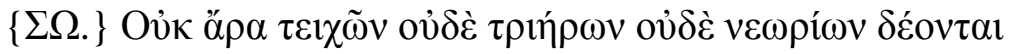

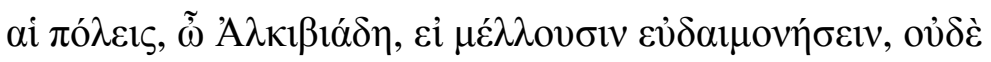

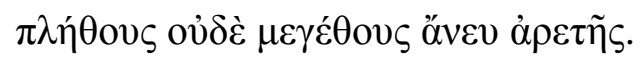

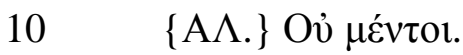

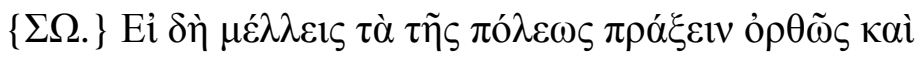

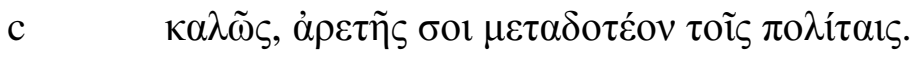

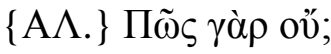

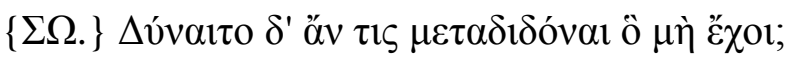

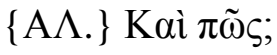

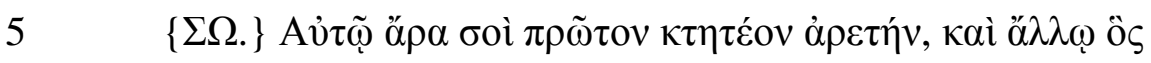

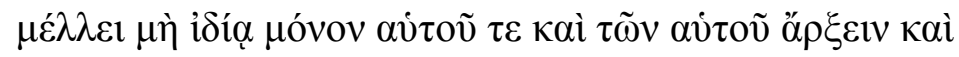


[ALC.] Tampouco isso.

[SÓC.] E, por não saber, ele não cometerá erros?

[ALC.] Certamente.

[SÓC.] E, ao cometer erros, não estará agindo mal tanto no âmbito público quanto no privado?

[ALC.] Como não?

[SÓC.] E, ao agir mal, não seria ele infeliz?

[ALC.] Sim, absolutamente.

[SÓC.] E o que sucede àqueles em vista dos quais ele age?

[ALC.] Esses também o seriam.

[SÓC.] Não é possível, portanto, que alguém seja feliz, se não for temperante e bom.

[ALC.] Sim, não é possível.

[SÓC.] Os homens maus, portanto, são infelizes.

[ALC.] Sim, absolutamente.

[SÓC.] Não é, portanto, quem se torna rico que se liberta da infelicidade, e sim quem se torna temperante.

[ALC.] É claro.

[SÓC.] Por conseguinte, se as cidades visam a felicidade, elas não necessitam de muralhas, nem de trirremes, nem de estaleiros, ó Alcibíades, nem de uma massa de gente, nem de magnitude, sem excelência.

[ALC.] Não mesmo.

[SÓC.] Se, então, você visa a prática política correta e bela, você deve transmitir a excelência aos cidadãos.

[ALC.] E como não?

[SÓC.] E alguém seria capaz de transmitir o que não possui?

[ALC.] Como o seria?

[SÓC.] Você deve, portanto, primeiro adquirir a excelência, assim como qualquer outro indivíduo que vise o comando e o cuidado, não somente de si próprio e do que lhe diz respeito no âmbito privado, 


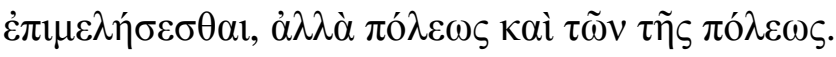

$\{\mathrm{A} \Lambda.\}{ }^{\prime} \mathrm{A} \lambda \eta \theta \tilde{\eta} \lambda \varepsilon \dot{\gamma \varepsilon \iota \varsigma}$.

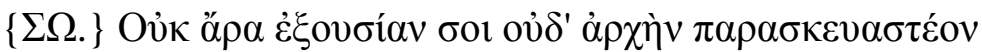

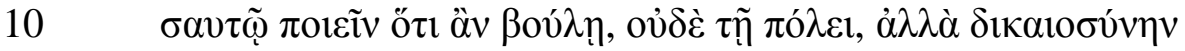

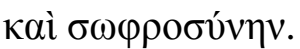

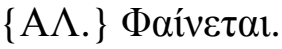

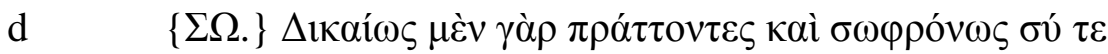

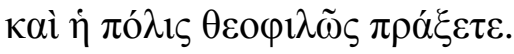

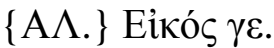

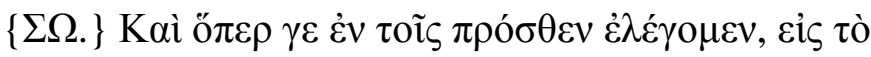

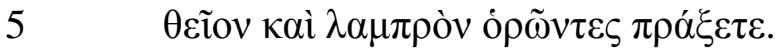

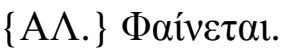

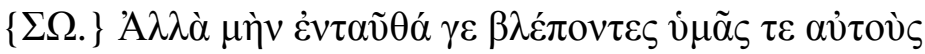

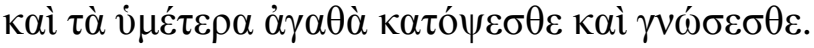

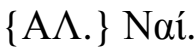

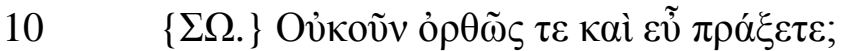

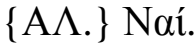

e

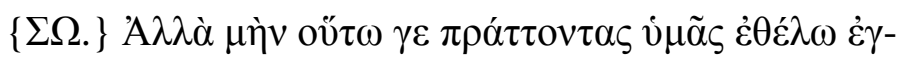

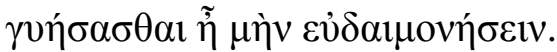

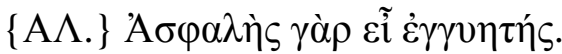

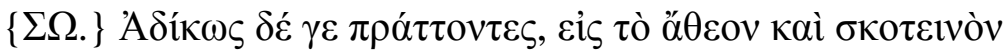

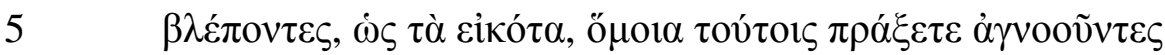

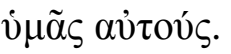

$\{\mathrm{A} \Lambda.\}{ }^{\prime}$ Eо1кеv.

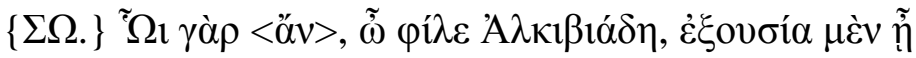

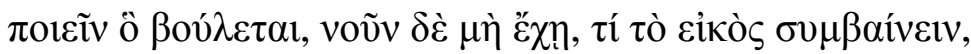

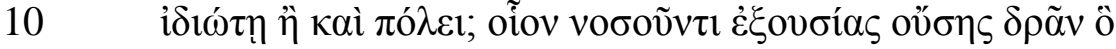

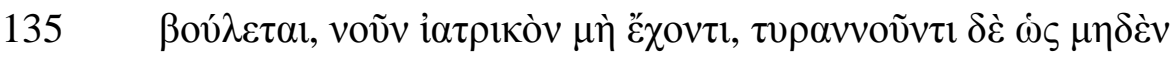

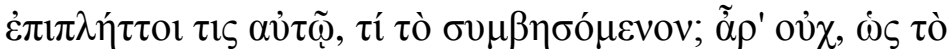


mas também da cidade e do que lhe diz respeito.

[ALC.] Você diz a verdade.

[SÓC.] Você não deve, portanto, obter licença e poder para fazer a si mesmo e à cidade o que quiser, e sim justiça e temperança.

[ALC.] É claro.

[SÓC.] Pois, executando suas tarefas de maneira justa e temperante, você e d a cidade as estarão executando de maneira cara aos deuses.

[ALC.] É plausível que sim.

[SÓC.] E justamente aquilo que dissemos ainda há pouco, as estarão executando com o olhar voltado para o divino e luminoso.

[ALC.] É claro.

[SÓC.] E ao olharem para lá, certamente contemplarão e conhecerão a vocês mesmos e às coisas boas que lhes dizem respeito.

[ALC.] Sim.

[SÓC.] Então, não as executarão de modo bom e correto?

[ALC.] Sim.

[SÓC.] Com efeito, se as executarem dessa maneira, desejo lhes oferecer e esta garantia: vocês serão felizes.

[ALC.] E isso é confiável, se você o garante.

[SÓC.] Mas, se as executarem de maneira injusta, com seus olhares voltados para o obscuro e sem deus, vocês as executarão, como é plausível, de maneira similar, por não conhecerem a vocês mesmos.

[ALC.] É razoável.

[SÓC.] Pois se alguém, ó Alcibíades, tiver o poder de fazer o que lhe apraz, o que aconteceria a ele e à cidade? Por exemplo, se um doente tiver a liberdade de fazer o que quiser, sem ter conhecimento médico, mas agindo como um tirano a quem ninguém censuraria em nada, o que haverá de acontecer? Acaso, como é 


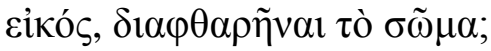

$\left\{\mathrm{A \Lambda . \}} \AA^{\wedge} \lambda \eta \theta \tilde{\eta} \lambda \dot{\varepsilon} \gamma \varepsilon 1 \zeta\right.$.

5

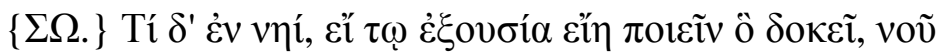

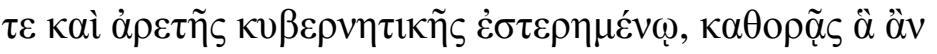

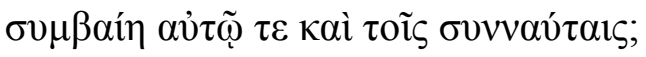

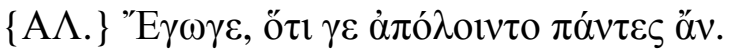

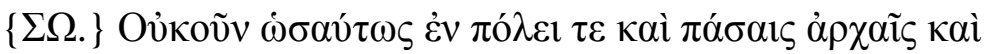

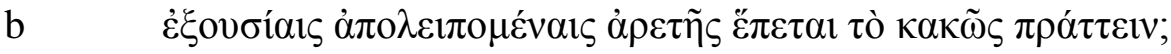

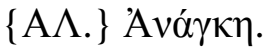

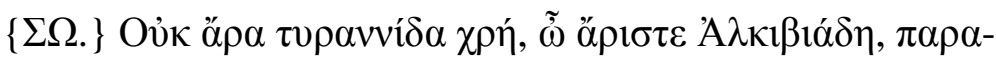

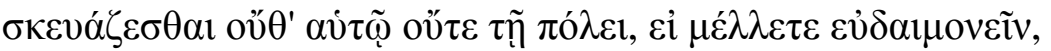

$5 \quad \dot{\alpha} \lambda \lambda^{\prime} \dot{\alpha} \rho \varepsilon \tau \eta \dot{v}$.

$\{\mathrm{A} \Lambda$.$\} 'A \lambda \eta \theta \tilde{\eta} \lambda \varepsilon \dot{\varepsilon \varepsilon \varepsilon 1 \zeta . ~}$

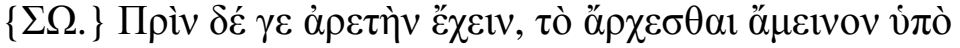

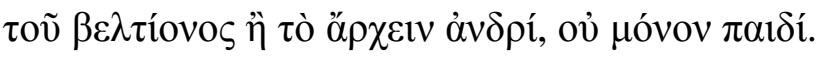

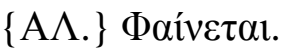

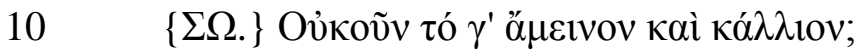

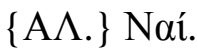

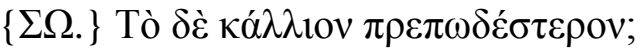

c

$\{\mathrm{A} \Lambda.\} \Pi \tilde{\omega} \varsigma \delta^{\prime}$ ỡ;

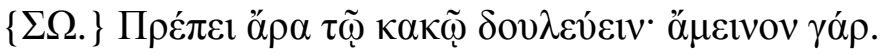

$\{$ A $\Lambda$.$\} Naí.$

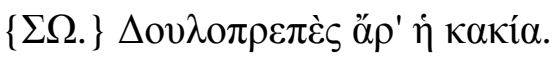

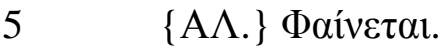

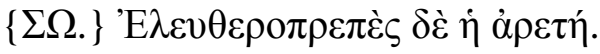

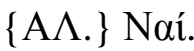

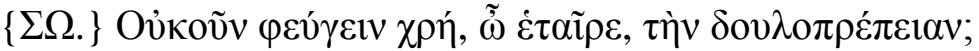

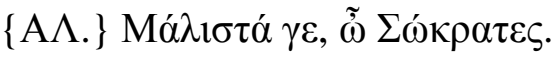

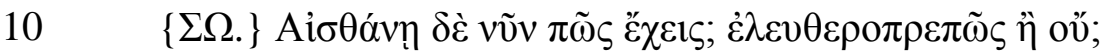


plausível, o seu corpo não seria lesado?

[ALC.] É verdade o que você diz.

[SÓC.] E no caso de um navio: se alguém tivesse o poder de fazer o que lhe parecesse correto, privado da inteligência e da virtude próprias da navegação, você consegue vislumbrar o que ocorreria a ele próprio e aos nautas?

[ALC.] Sim; eu penso que todos morreriam.

[SÓC.] E não sucede a mesma coisa à cidade e a todo e qualquer poder ou magistrado: apartados da excelência, a consequência é agir mal?

[ALC.] É forçoso que sim.

[SÓC.] É preciso, portanto, ó excelente Alcibíades, que não seja fornecido nem a você nem à cidade o poder supremo, e sim a excelência, caso vocês visem a felicidade.

[ALC.] Você diz a verdade.

[SÓC.] Antes de possuir a excelência, é melhor que o homem, não somente a criança, seja comandado por um homem melhor, ao invés de comandar.

[ALC.] É claro.

[SÓC.] E o melhor não é também o mais belo?

[ALC.] Sim.

[SÓC.] E o mais belo, não é o mais conveniente?

[ALC.] Como não?

[SÓC.] A condição servil, portanto, convém ao homem mau. Pois é melhor para ele.

[ALC.] Sim.

[SÓC.] O vício, portanto, é apropriado a um escravo.

[ALC.] É claro.

[SÓC.] E a virtude é apropriada a um homem livre.

[ALC.] Sim.

[SÓC.] E não é preciso escapar, meu caro, da escravidão?

[ALC.] Acima de tudo, ó Sócrates.

[SÓC.] Percebe, agora, a sua condição? Você está na condição de um homem livre, ou não? 


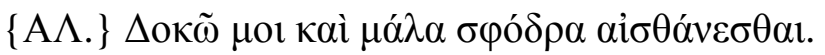

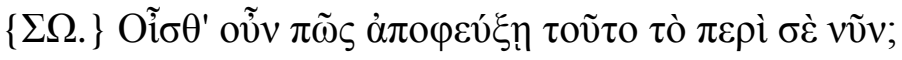

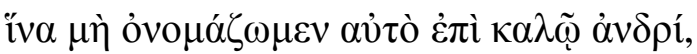

d

$\{\mathrm{A} \Lambda.\}{ }^{\prime} \mathrm{E} \gamma \omega \gamma \varepsilon$.

$\{\Sigma \Omega.\} \Pi \tilde{\omega} \zeta$

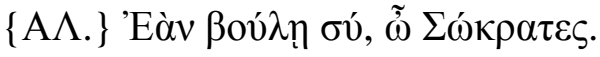

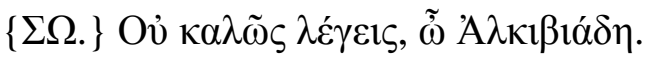

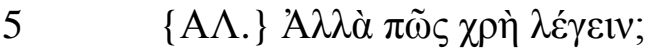

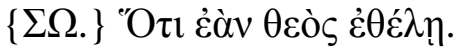

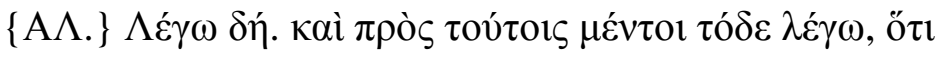

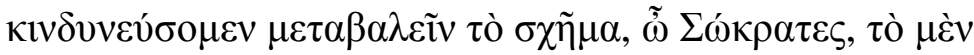

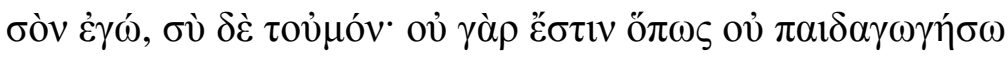

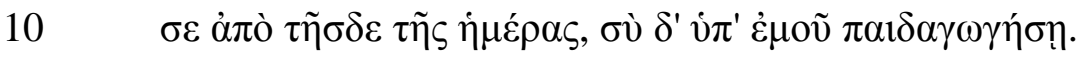

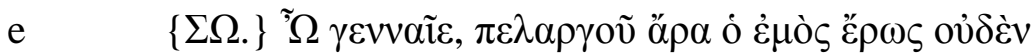

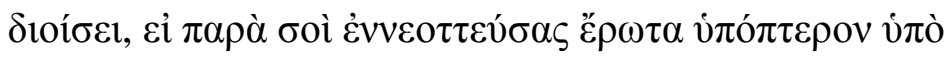

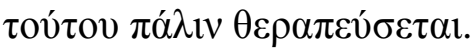

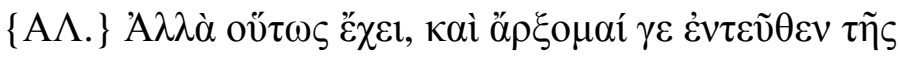

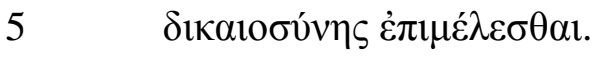

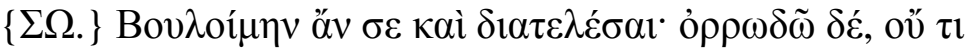

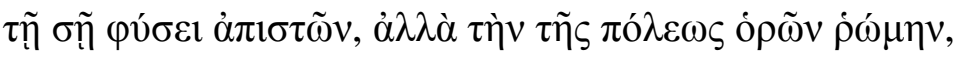

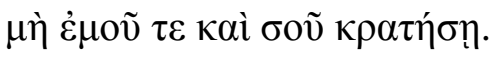


[ALC.] Parece que agora a percebo muito melhor.

[SÓC.] E você sabe, então, como deve escapar desta sua presente condição?

Que não tenhamos de denominá-la diante de um belo homem!

[ALC.] Sim, eu sei.

[SÓC.] Como?

[ALC.] Se você o desejar, ó Sócrates.

[SÓC.] Não é bela a sua resposta, ó Alcibíades.

[ALC.] Mas, então, como eu devo responder?

[SÓC.] Se o deus o desejar.

[ALC.] Assim responderei. E, além disso, ainda digo o seguinte: que haverá a possibilidade de trocarmos os papéis, ó Sócrates, eu assumindo o seu, e você, o meu; pois é impossível que, a partir de hoje, eu não me dedique à sua companhia como se fosse seu preceptor, e que você não seja acompanhado por mim como seu preceptor.

[SÓC.] Ó nobre amigo, o meu amor, portanto, em nada diferirá do da cegonha, se, depois de ter incubado um amor alado em você, este for objeto, em troca, de seu cuidado.

[ALC.] Mas assim será. E, a partir de agora, começarei a cuidar da justiça.

[SÓC.] Eu gostaria muito que você cumprisse isso. Mas temo, não por desconfiar de algum modo de sua natureza, mas por observar o poderio da cidade, que este domine a mim e a você. 


\section{REFERÊNCIAS BIBLIOGRÁFICAS}

ALLEN, R. E. "Note on Alcibiades I, 129b1". The American Journal of Philology. Vol. 83, No. 2, 1962, pp. 187-190.

AMBURY, JAMES M. “The place of displacement: the elenchus in Plato's Alcibiades I'. Ancient Philosophy. Vol. 31, 2011, pp. 241-260.

BLUCK, R. S. "The Origin of the Greater Alcibiades". The Classical Quarterly. New Series, Vol. 3, No. 1-2, 1953, pp. 46-52.

BOLZANI, R. "O Cênico no Protágoras". Revista Brasileira de Estudos Clássicos. São Paulo, v. 13/14, 2001, p. $219-231$.

BRICKHOUSE, THOMAS C. AND SMITH, NICHOLAS D. Plato's Socrates. Oxford University Press, 1995.

DENYER, N. Plato. Protagoras. Cambridge University Press, 2008.

GORDON, J. "Eros and Philosophical Seduction in Alcibiades I". Ancient Philosophy. Vol. XXIII n. 1, 2003.

HOOPER, ANTHONY. “The Dual-Role Philosophers: An Exploration of a Failed Relationship". Alcibiades and the Socratic Lover-Educator. London: Bristol Classical Press, 2012, pp. 107-118.

IRWIN, TERENCE. Plato's ethics. Oxford University Press, 1995.

JAKUB JIRSA. "Authenticity of the Alcibiades I: some reflections". Listy filologické CXXXII. 2009, 3-4, pp. 225-244.

KAHN, CHARLES H. Plato and the Socratic dialogue: the philosophical use of a literary form. Cambridge University Press, 1996. 
KOYRE, ALEXANDRE. Discovering Plato. Translated by Leonora Cohen Rosenfield. Columbia University Press, 1945.

LOPES, D.R.N. Górgias de Platão. São Paulo: Perspectiva, 2011.

MINTOFF, JOE. "Did Alcibiades Learn Justice from the Many?". Alcibiades and the Socratic Lover-Educator. London: Bristol Classical Press, 2012, pp. 90-106.

MARGUERITE JOHNSON, HAROLD TARRANT. Alcibiades and the Socratic LoverEducator. London: Bristol Classical Press, 2012.

NYE, A. "The Subject of Love: Diotima and her Critics". Journal of Value Inquiry. Vol. 24, 1990, pp. 135-153.

PLATÃO. Apologia de Sócrates. Introdução, tradução e notas André Malta. São Paulo: L\&PM, s/d.

O Banquete. Tradução, introdução e notas de Maria Teresa Schiappa de Azevedo. Lisboa: Edições 70, 2008.

. A República. Tradução e organização J. Guinsburg. São Paulo: Perspectiva, 2006.

PLATO. Alcibiades. Edited by Nicholas Denyer. Cambridge University Press, 2001.

. Complete Works. Edited with introduction and notes by John M. Cooper. Mackett Publishing Company, 1997.

Platonis Opera. Tomus II, edited by John Burnet. Oxford Classical Texts: Clarendon Press, 1967. 
RENAUD, FRANÇOIS. "Socrates' Divine Sign: From the 'Alcibiades' to Olympiodorus". Alcibiades and the Socratic Lover-Educator. London: Bristol Classical Press, 2012, pp. 190-199.

SCOTT, GARY ALAN. Plato's Socrates as educator. State University of New York Press, 2000.

SMITH, NICHOLAS D. "Did Plato Write the "Alcibiades I'?". Apeiron: A Journal for Ancient Philosophy and Science. Vol. 37, No. 2, 2004, pp. 93-108.

THOMAS, ROSALIND. Letramento e oralidade na Grécia Antiga. Tradução de Raul Fiker, São Paulo: Odysseus Editora, 2005.

WELLMAN, ROBERT R. "Socrates and Alcibiades: The Alcibiades Major". History of Education Quarterly. Vol. 6, No. 4, 1966, pp. 3-21. 